VANESSA MIES BOMBARDI

\title{
A REBELIÃO DO DIA-A-DIA: \\ UMA LEITURA SOBRE ADOLESCENTES AUTORES DE ATOS INFRACIONAIS
}

SÃO PAULO

2008 
AUTORIZO A REPRODUÇÃO E DIVULGAÇÃO TOTAL OU PARCIAL DESTE TRABALHO, POR QUALQUER MEIO CONVENCIONAL OU ELETRÔNICO, PARA FINS DE ESTUDO E PESQUISA, DESDE QUE CITADA A FONTE.

Catalogação na publicação Serviço de Biblioteca e Documentação Instituto de Psicologia da Universidade de São Paulo

Bombardi, Vanessa Mies.

A rebelião do dia-a-dia: uma leitura sobre adolescentes autores de atos infracionais / Vanessa Mies Bombardi; orientadora Sylvia Leser de Mello. -- São Paulo, 2008.

$342 \mathrm{p}$.

Dissertação (Mestrado - Programa de Pós-Graduação em Psicologia. Área de Concentração: Psicologia Social) - Instituto de Psicologia da Universidade de São Paulo.

1. Adolescente em conflito com a lei 2. Violência 3. Meios de comunicação de massa 4. Fetichismo 5. Formação do indivíduo I. Título. 


\title{
A rebelião do dia-a-dia: uma leitura sobre adolescentes autores de atos infracionais
}

\author{
Vanessa Mies Bombardi
}

BANCA EXAMINADORA

(Nome e Assinatura)

(Nome e Assinatura)

(Nome e Assinatura)

Dissertação defendida e aprovada em: 
Dedico este trabalho a todas as crianças e jovens que, com suas vidas ajudaram a construir a minha história. 


\section{AGRADECIMENTOS}

Agradeço a Capes pelo financiamento, sem o qual este trabalho não seria possível.

Ao Newton pelo acompanhamento carinhoso e pela força nos períodos de desespero.

A Sylvia, minha orientadora, pelo incentivo constante e por oferecer um acompanhamento que respeita a opinião e o modo de ser e pensar de seus orientandos.

Aos jovens que participaram dessa pesquisa - Alex, Breno, Douglas e Lucas.

Ao Zeca e a Lurdinha pelas contribuições fundamentais durante a minha formação e atuação profissional e pelas contribuições valiosas no Exame de Qualificação.

A Associação Novolhar pelos tempos que trabalhei lá e ao Paulo Santiago por ter me passado o contato dos jovens que entrevistei.

A Elaine, dedicada profissional que conheci na Associação Mutirão, pela apresentação de Douglas.

A Eliane pela leitura atenta da entrevista do Breno, pela companhia em uma longa e louca viagem pelo mundo e pelo incentivo para a realização do mestrado.

A Fátima pela amizade e por ter aceitado o meu pedido para leitura dessa dissertação. Ao Edu e ao Matheus por cuidarem de tudo enquanto ela lia o texto, trabalhava, fazia seu mestrado....

A minha irmã Larissa pelas indicações de textos, pela assistência na estrutura da escrita e pelo apoio ao longo do mestrado.

Ao Snoopy pelo socorro imediato quando um falso vírus resolveu aparecer nos arquivos da dissertação.

Ao Ciro que sempre socorre quando o assunto é informática.

Aos meus pais Isa e Paulo pelo incentivo constante aos estudos.

A Cecília, a Nalva, a Leny e a todos do PST que me auxiliaram quando precisei.

As funcionários da secretaria de pós-graduação e da biblioteca pelo apoio aos alunos da Psico. 


\section{SUMÁRIO}

Resumo viii

Abstract

1. Apresentação 2

2. Introdução 9

3. A distância necessária - a pesquisa 22

4. Os adolescentes julgados autores de atos infracionais 36

4.1. A adolescência 36

4.2. Perfil dos adolescentes que cumprem medidas socioeducativas $\quad 42$ no Estado de São Paulo

5. Os jovens entrevistados - o recorte da violência ao longo de 57 suas vidas

5.1. Alex - a guerra na cidade grande 62

5.2. Breno - o corpo sem forma, a perda do passado 68

5.3. Douglas - a (des)confiança e a violência sentida 71

5.4. Lucas - a vida em rebelião, a violência no dia-a-dia 80

6. O processo de exclusão e o fetiche das mercadorias 87

7. Infração - o ato na (im)possibilidade da ação 114

8. As violências 133

$\begin{array}{ll}\text { 8.1. Os dados que ajudam a compreender o fenômeno } & 133\end{array}$

8.2. As crianças e adolescentes como vítimas de graves violações 137 aos direitos humanos e violência fatal

8.3. Todos são vítimas: os adolescentes vitimados pela violência $\quad 140$ transformam-se em autores de violência

8.4. Analisando a violência praticada e sofrida por adolescentes 146

8.5. A possibilidade do terror 152

9. As leis 164 
9.1. O Estatuto da Criança e do Adolescente e a prática infracional

9.2. As medidas socioeducativas em números

10. A mídia

11. Aproximação - o resgate de cada um

11.1. A história de Breno

11.2. A história de Lucas

11.3. A história de Alex 232

11.4. A história de Douglas

12. Considerações finais - a costura possível

Anexos

A-Entrevista Alex

B-Entrevista Breno

C-Entrevista Douglas 297

D-Entrevista Lucas

Referências bibliográficas 


\section{LISTA DE TABELAS}

Tabela $n^{\circ}$

Página

1. Escolaridade dos adolescentes internos da Febem-SP em 2006

2. Distribuição das ocorrências policiais que envolvem adolescentes infratores, segundo a natureza da infração - município de São Paulo 1988-1996.

3. Número de adolescentes e jovens no sistema socioeducativo (SSE) segundo a modalidade de atendimento no sistema - Brasil (Janeiro/2004).

4. Número de adolescentes e jovens no sistema socioeducativo, por modalidade de medida, segundo região (Janeiro/2004).

5. Número de adolescentes em meio fechado - estado de São Paulo em 2006.

6. Como o Estatuto da Criança e do Adolescente foi citado nas matérias em que foi mencionado.

7. Quantidade de preso por faixa etária no sistema penitenciário adulto no estado de São Paulo em Junho de 2007. 


\section{RESUMO}

Bombardi, V. M. A rebelião do dia-a-dia: uma leitura sobre adolescentes autores de atos infracionais. São Paulo. 2008. 342p. Dissertação (Mestrado) Instituto de Psicologia. Universidade de São Paulo.

Este trabalho partiu da hipótese de que adolescentes cometem ato infracional como decorrência do processo de formação do indivíduo, engendrado na sociedade de consumo. Teve o objetivo de dar voz a esses adolescentes. Ouvilos para transformá-los em agentes de sua própria história. Partiu de concepções críticas de psicologia, de homem e de mundo enfocando a história da sociedade ocidental em relação à possibilidade de formação/constituição do ser humano. A metodologia utilizada foi o estudo de caso. Para tanto coletou informações a partir de várias fontes de evidências, sendo elas: a análise documental sobre as leis que lidam com a questão da infância brasileira e sobre o que foi divulgado pela mídia quando o assunto eram as crianças e adolescentes; registros sobre estatísticas da violência no Brasil e sobre o perfil dos adolescentes que cumpriram uma medida socioeducativa; entrevistas com quatro jovens que cometeram ato infracional na adolescência e observação direta proporcionada por experiência anterior de trabalho com esse público. A dissertação apresentou o fenômeno da prática infracional de adolescentes como consequência da impossibilidade de plena formação do humano na sociedade atual. O fetichismo exercido pelas mercadorias, a influência da indústria cultural e da pseudoformação oferecida pelas escolas, a inexistência de espaços de convivência entre homens livres foram componentes fundamentais para entender a violência efetuada e sofrida pelos jovens. Estes estão impedidos de aparecerem como seres plurais e ao mesmo tempo únicos.

Palavras-chave: adolescentes em conflito com a lei; violência; mídia; fetichismo da mercadoria; visibilidade perversa; condição humana. 


\begin{abstract}
Bombardi, V. M. A rebelião do dia-a-dia: (A Day-by-day Rebellion) An interpretation about young offenders. São Paulo. 2008 (342p) Dissertation (mastering) Instituto de Psicologia. Universidade de São Paulo.
\end{abstract}

This study originated from the hypothesis that adolescents commit offences due to the process of formation of the individual, inserted in the consuming society. It has had as main objective to give those adolescents a say. To hear them to make them agents of their own history. It stemmed from critical conceptions of psychology, of the man and of the world, focusing on the History of the western society related to the possibility of formation/constitution of the human being. The methodology employed was the case study. Thus, some information has been collected from several sources of evidence, such as: the documental analysis about the laws which deal with the question of the Brazilian childhood and about what has been broadcast by the media when the subject has been children and teenagers, registers about statistics of the violence in Brazil and about the profile of the adolescents who have been submited to a social-educative measure; interviews with four youngsters who commited offences as teenagers and direct observation provided by previous working experience with this group. The dissertation presented the phenomenon of the teenage criminal practice as consequence of the failing in fully forming humans in the present society. The fetiche exerted by products, the influence of the cultural industry and of the pseudoformation offered by schools, the lack of interactive spaces among free men have been the fundamental components to understand the violence commited and undergone by the youth. These are prevented from emerging as plural beings and as well as single ones.

Key words: Young offenders; violence; media; fetiche of the products; perverse visibility; human condition. 
Capítulo 1 - APRESENTAÇÃO 


\section{APRESENTAÇÃO}

[...] Fugimos destes homens que, agora reduzindo os outros ao objeto de suas ameaças, fogem de si mesmos - perdemos, nós todos. (...) Entre nós, o medo e o silêncio [....]

[...] A humilhação pede a voz e não as mordaças. Perdemos a chance de escutá-los e, escutando-os, considerar nossa parte na produção de sua indigência. (GONÇALVES FILHO. 1995. p.163)

No transcorrer do primeiro ano do curso de psicologia, eu e uma amiga da faculdade estávamos indo ao Vale do Anhangabaú para assistir a um show musical patrocinado pela prefeitura de São Paulo. Logo após a saída do metrô, na Avenida Xavier de Toledo, em um canto debaixo de uma marquise, nós avistamos dois policiais surrando um menino que, pela aparência, estava dormindo nas ruas há tempos. Fiquei estática diante da cena. Queria fazer algo, mas a cena violenta paralisou-me. Um transeunte que acompanhava a situação nos afastou do local. Afirmou que sofreríamos conseqüências caso interviéssemos. Até hoje não sei ao certo a que conseqüências ele se referia, mas com certeza aquela cena deixou marcas.

$$
\equiv
$$

O ano era 1997 e eu trabalhava no SOS Criança com crianças em situação de rua. Dirigindo o carro no caminho para o trabalho, o trânsito lento permitiu que eu observasse em volta. Meu olhar cruzou com um garoto sentado na calçada da Avenida Rebouças. Logo à frente o farol fechou e eu, absorta na cena vista, não percebi a aproximação daquele menino. Com um caco de vidro na mão ele me obrigou a dar-lhe dinheiro. Tentei dialogar, mas não havia espaço para a palavra. A violência paralisante obriga a seguir a ordem dada. Fiquei pensando que poucas pessoas olham nos olhos dos meninos maltrapilhos que pedem nos faróis. Invadi um espaço pouco exercitado; sem o treino da troca, também fui invadida. 
No início de 2004 fui convidada a exercer a função de diretora em uma unidade de semiliberdade da Febem. Era uma semiliberdade invertida: os adolescentes passavam o dia na unidade e iam para casa à noite.

Proposta nova, funcionários novos, muitas esperanças.

Alguns problemas foram percebidos logo de início: o prédio era um antigo presídio, completamente inadequado para o cumprimento de medidas socioeducativas. Não houve apresentação e discussão da proposta de trabalho para as outras unidades e funcionários da instituição. As questões pessoais e institucionais logo se fizeram presentes nos encaminhamentos dos adolescentes, no descrédito ao trabalho, nas supervisões incoerentes com a "nova proposta".

Impossível estabelecer mudanças radicais de cima para baixo. Elas são construídas no fazer cotidiano, com a ação e transformação de todos os envolvidos: dirigentes, técnicos, adolescentes, familiares. A superação das contradições pressupõe a transformação de todos.

A unidade permaneceu em funcionamento por cerca de dois anos. Cada profissional levou consigo algo transformado. Eu carreguei a vontade de estudar para compreender esses meninos que muito me ensinaram.

\section{$\equiv$}

Sexta-feira, mês de dezembro de 2006, o ônibus em direção ao centro da cidade estava lotado. Fiquei na porta alguns pontos até que pudesse avançar para o meio do coletivo. Quando já estava sentada, um homem que aparentava ter entre 40 e 50 anos se aproximou. Carregava uma sacola do "Dose Certa" e parecia exausto. Perguntei se ele estava se sentindo bem, apontei para a sacola de remédios... Ele respondeu que estava bem e que ia ao centro da cidade para dar baixa na sua Condicional.... A conversa engrenou.

Esse senhor falou-me dos três anos que ficou na cadeia, do que aconteceu para ser preso, de como era a vida lá dentro, de como estava a vida aqui fora.

Ele comentou que dentro da cadeia era muito difícil - não se pode dever para ninguém; você tem o direito de não querer entrar no "esquema",

\footnotetext{
${ }^{1}$ Programa do Governo do Estado de São Paulo para distribuição de medicamentos.
} 
mas precisa ficar quieto; não pode contar nada do que sabe; não deve receber cartas para não identificarem seu endereço e irem mexer com sua família. Enlouquecedor?

Aquele senhor não olhava pra mim no início da conversa - vergonha? Medo de ser identificado? Ele estava disposto a falar e eu a ouvir. Logo os olhares puderam se cruzar. Olhares rápidos e desconfiados. De vez em quando olhava pra mim, outras vezes seus olhos percorriam o entorno....

A viagem chegou ao fim na Praça Ramos de Azevedo. Fomos os últimos a descer do ônibus. Fiquei olhando ele avançar pela escadaria do Vale do Anhangabaú.....

Algumas frases ditas por aquele senhor ficaram na cabeça...

Eles sabem que eu saí, perguntaram se quero ajuda, mas não aceitei, e depois, como vai ficar?

Expliquei pro meu filho que a vida lá dentro não é fácil, ele já sabe, a escolha é dele, mas se se envolver, não traga ninguém pra dentro da minha casa.

Quando o Comando assumiu, melhorou muito, a cadeia está mais certa agora. Eu tirei três anos, parece que foram dez.

Eles me ajudaram com advogado, não posso falar nada do que vi.

Eu não estou em casa, estou em... pra afastar um pouco de lá.

Os policiais acham que são juízes, mas a gente sabe que tem o direito de passar por processo e ser julgado pelo juiz, a gente sabe desse direito. Apanhei muito, mas eles não são juízes...

Tenho uma filha e um filho, eu expliquei tudo pra eles, a escolha é deles.

Quanto a se pensar a partir dessas cenas! Como entender a violência? Como são construídas as escolhas para entrar no crime? Como encontrar o humano de cada um, perdidos que estamos nessa metrópole excludente e injusta?

Outras tantas histórias ouvidas e partilhadas durante os 12 anos de trabalho com crianças e adolescentes estão presentes nesta pesquisa. Foi por esses encontros que escolhi o tema: adolescente pobre, autor de ato infracional. 
servir? Estes enigmas não constituem enigmas para eles próprios? [...] Ainda resistimos a sua humanidade, por que?(GONÇALVES FILHO. 1995. p. 2)

Essas e outras questões levaram-me a trabalhar com adolescentes e jovens pobres, moradores das periferias da Grande São Paulo. As perguntas que inquietavam o professor durante a elaboração de sua dissertação foram plantadas também em nós, bolsistas-monitores da disciplina Psicologia Social II, em 1994/1995.

Mais de dez anos depois, realizei essa pesquisa com adolescentes que foram julgados autores de atos infracionais. Por que só olhamos para eles quando batem no vidro fechado do carro ou quando estão nos telhados das Febem(s)? Quem são? Onde moram? Como pensam suas vidas?

Alex, Lucas, Douglas e Breno ${ }^{2}$ foram jovens que partilharam suas histórias comigo para a elaboração desta dissertação. Por meio dos quatro jovens dei voz a muitos outros.

Proponho incentivar os leitores na escuta desse grupo que é pouco ouvido, raramente é olhado, e no geral, só é tocado quando está apanhando.

$\mathrm{Na}$ Introdução da dissertação propus a hipótese da pesquisa, a pergunta inicial e os objetivos. Aproximo o leitor do tema de meu interesse.

No capítulo A Distância Necessária - A Pesquisa foi apresentado o referencial teórico, a metodologia que mais se adequou à questão que foi desenvolvida ao longo do trabalho e a maneira pela qual conheci e entrevistei os jovens que participaram desta pesquisa.

Em Os Adolescentes Julgados Autores de Atos Infracionais foi discutido o conceito de adolescência. No mesmo capítulo foi apresentado o perfil dos adolescentes que cumpriam medida socioeducativa na Febem - SP, atual Fundação Casa, em maio de 2006. Esses dados foram acompanhados de uma discussão pertinente envolvendo a história dos jovens entrevistados.

No capítulo Os Jovens Entrevistados - o recorte da violência em suas vidas foi feito um resgate das situações violentas que vivenciaram. Foram

\footnotetext{
${ }^{2}$ Os nomes são fictícios para evitar identificações.
} 
considerados atos violentos qualquer ação ou omissão que impedisse a humanidade no homem - tanto na vida dos jovens entrevistados como de suas vítimas. Aqui o leitor pode iniciar um contato com a singularidade dos sujeitos.

O Processo de Exclusão e o Fetiche da Mercadoria é o capítulo em que foram discutidos aspectos da sociedade capitalista que, junto com outras situações, compõem um campo de forças que pode levar uma pessoa à prática de atos infracionais. Martins, Adorno, Horkheimer e Roman foram os autores que auxiliaram na elaboração desse pensamento.

No capítulo Infração - O Ato na (IM)Possibilidade da Ação foi discutida, com o apoio da obra de Hannah Arendt, a impossibilidade de plena formação do indivíduo na sociedade contemporânea. A autora permitiu pensar as condições em que a ação política poderia transformar o encontro entre as pessoas em uma ação entre seres singulares.

Em As Violências foram discutidos dados que contextualizam a violência adolescente. Eles são, antes de tudo, vítimas, mais que autores de atos violentos. Os dados analisados foram obtidos a partir de uma pesquisa realizada pelo Núcleo de Estudos de Violência da USP. No mesmo capítulo foram discutidos aspectos da violência e a possibilidade do terror na sociedade contemporânea.

O capítulo As Leis apresentou o processo histórico de elaboração de leis que regeram, ao longo do tempo, a vida das crianças e adolescentes brasileiros. Conhecer esse processo auxiliou na compreensão do fenômeno da prática infracional de pessoas com menos de 18 anos.

A Mídia é um capítulo que mostrou a importância do papel da imprensa na afirmação de conceitos que promovem uma determinada visão dos acontecimentos. Foram utilizados documentos que analisaram o comportamento da mídia impressa brasileira quando o assunto envolvia crianças e/ou adolescentes. 
Aproximação - O resgate de cada um levantou aspectos da vida dos jovens entrevistados que foram importantes para que eles deixassem de praticar infrações. O encontro com um outro, diferente na forma de ser e igual na sua condição humana. $\mathrm{O}$ encontro destituído de interesses. Um encontro entre pessoas.

Finalmente o capítulo Considerações Finais - A Costura Possível realizou uma aproximação entre todos os aspectos discutidos ao longo do trabalho.

Nos Anexos é possível encontrar as entrevistas dos quatro jovens na íntegra. Ali eles aparecem sem o recorte do olhar do pesquisador.

Todos os capítulos foram fundamentais para o entendimento de um fenômeno tão complexo como a prática infracional de adolescentes na sociedade brasileira contemporânea. A separação da dissertação em capítulos se faz necessária para tornar claro o pensamento do pesquisador. Porém, os assuntos estão todos interligados, o que pode provocar a impressão de que houve repetição na discussão.

Houve sim a repetição na citação de algumas falas dos jovens entrevistados, pois a experiência de uma pessoa nunca é desconectada de outros aspectos de sua vida. Contextualizar um fato pode auxiliar na discussão de um assunto e ao mesmo tempo manter o indivíduo inteiro com sua história. 
Capítulo 2 - INTRODUÇÃO 


\section{INTRODUÇÃO}

[...] O remédio para a humanidade desfeita é ainda a humanidade. (GONÇALVES FILHO. 1995. p. 164)

A prática infracional de adolescentes é um fenômeno complexo contraditório e dialético. Há determinações sociais e há condições individuais presentes no engendramento dessa questão. Porém, a mídia, a escola e as pessoas em geral afirmam (apoiados em um determinado olhar da ciência) que as infrações cometidas devem-se, exclusivamente, a condições pessoais (interiores ao indivíduo) ou no máximo, a condições familiares.

Existe uma representação na sociedade brasileira de que os jovens pobres são responsáveis pelos alarmantes índices de criminalidade.

[...] Esta mentalidade acaba por propor medidas de equacionamento deste adolescente-problema que se caracterizam por práticas repressivas, excludentes, pela convivência com o extermínio dos jovens, por justificar práticas cruéis, como o encarceramento e a tortura nos equipamentos destinados ao processo socioeducativo, por aderir a propostas equivocadas como a redução da idade penal, sempre retirando a credibilidade da legislação em vigor - o Estatuto da Criança e do Adolescente [...]. Esta mentalidade [...] exige, para sua desmontagem, a demonstração, tanto quanto possível, da multideterminação deste fenômeno, de sua articulação com os vários aspectos da vida coletiva, da cultura. (TRASSI. 2006. p. 17)

$\mathrm{O}$ ato infracional pode ter inúmeros significados: inconformismo, insubmissão, resistência à opressão, rebeldia, procura por apoio, afastamento das pessoas, violência sofrida e atualizada, vontade de mudança etc. Com todos esses possíveis significados, torna-se no mínimo ingênuo afirmar que a prática infracional de adolescentes é um acontecimento determinado por um único aspecto.

Esse trabalho pretendeu discutir a importância de se verificar as condições que vão para além do indivíduo, na prática infracional de adolescentes. 
“[...] ao deslocar a produção social da delinqüência para a hereditariedade, a família, a estrutura psíquica, ocultam-se suas origens históricas e sociopolíticas." (VICENTIN. 2005. p.38)

Desde que me formei na graduação em Psicologia, trabalhei com crianças em situação de rua e adolescentes e jovens pobres, moradores das periferias da Grande São Paulo. Alguns cometeram atos infracionais e cumpriram uma medida socioeducativa - de internação, semiliberdade, liberdade assistida (LA) ou prestação de serviços à comunidade (PSC).

$\mathrm{Na}$ Associação Novolhar ${ }^{5}$, tive a oportunidade de convivência prolongada com os adolescentes que estavam inseridos nas medidas socioeducativas de semiliberdade, LA ou PSC. A instituição oferecia um curso de capacitação na área de vídeo-produção e o objetivo era, através da produção de matérias jornalísticas, vídeo-clips e vídeos institucionais, construir junto com os adolescentes uma forma de estar no mundo que fosse autônoma, participativa, crítica e transformadora. A intenção não era adaptálos ao status quo, mas sim construir, com eles, mudanças em suas vidas.

Durante o desenvolvimento do trabalho tínhamos uma certeza - o fato de um adolescente cometer um ato infracional é um acontecimento engendrado por condições sociais e individuais; ou seja, para compreender esse fenômeno, não adianta estudar só os indivíduos ou só a sociedade, mas o encontro dos dois.

A partir de certas leituras, entre elas, o texto "Para um novo humanismo: contribuições da psicologia social" (DAMERGIAN e TASSARA. 1996), algumas afirmações importantes chamaram-me a atenção.

As relações sociais estão veladas pela ideologia e certas condições histórico-mundiais estão "garantindo" esse velamento. Fato que pode ser pensado a partir dos pseudos liberalismos denominados de neo-

\footnotetext{
${ }^{5}$ Associação Novolhar - www.novolhar.org.br. OSCIP que tem por missão contribuir para formação e desenvolvimento integral de crianças, adolescentes e jovens, suas famílias e comunidade, de modo crítico e criativo.
} 
liberalismos, que estão por trás de políticas econômicas produtoras de desigualdades sociais;

$\checkmark$ A impossibilidade de formação do humano nas condições determinadas pelo sistema capitalista de produção existente no mundo ocidental do final do século $\mathrm{XX}$, com mostras de que tendem a piorar as condições de exploração do trabalhador;

$\checkmark$ Essa sociedade capitalista está produzindo um processo de exclusão para diversos grupos de pessoas (entre eles, as famílias dos adolescentes que cometem ato infracional);

$\checkmark$ A mídia tem um importante papel no processo de impedimento da formação da identidade individual e grupal necessárias para a autonomia/democracia e questionamento dessa política de exclusões;

$\checkmark$ A necessidade dos dominados (os que possuem apenas sua mão-deobra como moeda no sistema capitalista de produção) romperem com o consenso da subordinação, ou seja, serem esclarecidos do processo de exploração a que estão submetidos cotidianamente.

A Psicologia Social pode contribuir para a transformação e superação dessas condições e unir forças no compromisso com uma nova possibilidade de existência e convivência entre ricos e pobres, com uma nova forma dos homens viverem em comunidades.

Nesse mesmo texto (DAMERGIAN e TASSARA. 1996), a definição de Psicologia Social revelou a importância de se fazer a pesquisa que propus sob a luz das contribuições possíveis para esse domínio da ciência. Uma vez que para ela, o homem é criador de história e de cultura.

Tais contribuições tornam-se mais relevantes quando se considera como seu domínio a compreensão das inter-relações dos aspectos cognitivos e afetivos de representações sociais compartilhadas por grupos, examinando quais condições sociais, linguagens e instrumentos de comunicação estão envolvidos na formação e preservação de um sistema de representações, e descrevendo as condições sob as quais esta estrutura ajuda a criação 
de uma visão coletiva. (Joodelet citado por Hughes, 1993 citado por DAMERGIAN e TASSARA. 1996)

Este trabalho apresentou o fenômeno da prática infracional por adolescentes como decorrência das condições sociais e da impossibilidade de plena formação do humano na sociedade atual. O fetichismo exercido pelas mercadorias, a Indústria Cultural e a pseudoformação ${ }^{6}$ oferecida pelas escolas são componentes fundamentais para entender a violência efetuada e sofrida pelos jovens.

Há a necessidade de vários olhares para compreender a questão.

[...] ir para além da aparência (do sintoma) e das representações sociais falseadoras da realidade [...] $\mathrm{O}$ tema adolescência-violência é um ponto crítico, de saturação, condensação de múltiplas determinações, pois revelador das mutações, transformações da cultura, dos padrões de relação entre os humanos, da fragilidade dos vínculos amorosos, do modo de pensar, sentir, agir - estar no mundo - dos indivíduos, neste momento histórico. (TRASSI. 2006. pp.204- 205)

Parti da hipótese de que os adolescentes que cometem ato infracional são fruto do processo de formação do indivíduo, engendrado na sociedade atual e que, portanto, o ato infracional é um fenômeno composto por condições individuais e sociais.

Marin (2002. p. 150) afirma que a delinqüência funciona como um "[...] mecanismo de denúncia social, afirmação do Eu, busca do mundo que foi perdido, rompido abrupta e arbitrariamente." Então, o ato infracional pode ser uma forma de pertencimento, de ser notado por essa sociedade que massifica, onde todos devem ser iguais a um modelo estabelecido?

Os adolescentes pobres que cometem atos infracionais sofrem e praticam múltiplas formas de violência. Cometer um ato infracional pode ser uma maneira de sentir-se incluído na sociedade do consumo?

\footnotetext{
${ }^{6}$ Conceitos que serão discutidos ao longo do texto.
} 
Ou será que o ato infracional seria uma forma de mostrar o seu descontentamento em relação às humilhações sofridas ao longo dos séculos, mesmo que o ato individual não proporcione mudanças no sistema opressor?

São questões amplas e complementares.

Ao longo do trabalho foi difícil definir uma única pergunta - todas estavam imbricadas. Essas perguntas, na realidade, mostraram-me que o interessante seria conhecer o fenômeno: quem são, como vivem e o que pensam os adolescentes autores de atos infracionais? $\mathrm{O}$ que $\mathrm{o}$ ato infracional de adolescentes está mostrando? Como os jovens conseguiram sair da vida criminal?

$\mathrm{O}$ ato infracional incluiu o adolescente na sociedade de consumo, produziu a sensação de pertencimento à sua comunidade, ao mesmo tempo em que produziu isolamento e desumanizou-o. Afastou-o das demais pessoas que foram vítimas de suas práticas e daquelas que ficaram com medo deles.

O mesmo adolescente passou a ser visto e desejado por mulheres que valorizavam sua coragem como sinal de virilidade masculina, pois elas acreditam que esta característica está presente em atos criminosos. Ao infracionar o jovem não questionou a sociedade em que vive, sentiu-se e atuou como vítima incapaz de críticas.

Ramia (1989) em "O Paradoxo do menor infrator institucionalizado: ser considerado anti-social pelo código penal, ao mesmo tempo em que reproduz a sociedade capitalista", citado por Vieira (2003. pp. 62-63) afirma:

“[...] $\mathrm{O}$ infrator agride os princípios da sociedade capitalista, na sua atividade infracional, mas reproduz os valores dominantes do capitalismo. Isso quer dizer que até mesmo sua atividade considerada ilegal e anti-social é motivada pela ideologia dominante e pelo mecanismo da alienação."

Violante (1982. p. 186), em "O dilema do decente malandro", citado por Vicentin (2005. p. 199), afirma que os atos infracionais:

São manifestações de revolta, de insubmissão às condições de vida que lhes são socialmente impostas. Não podem ser considerados comportamentos revolucionários porque se dão ao 
nível individual, competitivo, de modo desorganizado, demonstrando o limite possível da consciência desses indivíduos e a presença de crenças e valores dominantes. Não são, por isso, comportamentos transformadores de sua condição de vida, senão mantenedores. Não são a causa da desordem social, mas se constituem na sua denúncia.

$\mathrm{O}$ ato infracional pode significar uma rebeldia adolescente, mas essa reação os mantém adaptados ao mercado consumidor, normalizados frente aos desejos construídos para essa faixa da população.

Algumas situações que compõem um campo de forças que promove o engendramento do fenômeno podem ser enumeradas.

Entre elas, sugiro:

$\checkmark$ a pouca possibilidade de identificação com uma figura de autoridade que contribua para a formação do indivíduo, pois a identificação com seres genéricos, figuras vazias de história e identidade presentes no momento atual e incentivadas pela indústria cultural estão impedindo a humanização das pessoas;

$\checkmark$ o sentimento de desvalorização da sua cultura, desarticulada pela indústria cultural, poderosa indústria que se sobrepõe às várias iniciativas de valorização de sua comunidade - uma tentativa de resgate da história de cada grupo;

$\checkmark$ a impossibilidade de desvelar a ideologia dominante (de que os donos do capital têm o direito de explorar o trabalhador), levando-o a rebelar-se através da violência ou transgressão de regras;

$\checkmark$ a identificação com o valor de alguém a partir do valor dos objetos que pode adquirir, ou seja, a coisificação do humano;

$\checkmark$ o impedimento da plena formação do humano em uma sociedade que não permite a existência de homens livres.

A necessária desigualdade imposta pelo modo de produção capitalista entre aqueles que possuem os meios de produção e aqueles que têm apenas a 
sua força de trabalho, impõe a necessidade de organização de leis para que essa situação se sustente. Na sociedade atual a violência está legitimada como o uso da força para garantir o poder da minoria e da manutenção da propriedade privada.

O jovem brasileiro está envolvido por condições sociais que alimentam a idéia de que aquele que possui objetos de valor é que pode ser considerado como ser humano. Os objetos apresentados pela indústria cultural mudam com uma velocidade tão alucinante que a todo o momento o indivíduo acredita não ser alguém, pois sempre estará defasado em relação à aparição de novos objetos.

A ausência de condições dignas de vida, em que as necessidades básicas da existência não estão sendo satisfeitas; os trabalhos desumanos que mal garantem a permanência do indivíduo no mundo; a falta de espaços públicos de encontro com outros homens para troca de experiências, ação e aparição são uma constante. $\mathrm{O}$ consumo exagerado de mercadorias que praticamente não possuem existência, nem permitem ao homem se sentir integrante desse mundo, impedem a ação humana, como aponta Arendt (1997). E podemos afirmar que esse impedimento está presente para os adolescentes pobres, moradores das periferias das grandes cidades.

O adolescente que comete uma infração deve ser responsabilizado pelo seu ato - para isso servem as medidas socioeducativas. Não deve ser transformado em um criminoso - visto pela sociedade como alguém que deve ser enclausurado e afastado do convívio social.

Os adolescentes pobres brasileiros estão sendo vistos como sinônimos de violência, crime, perigo. Essa forma de vê-los encobre a multideterminação do fenômeno e transforma $o$ ato infracional em consequiência da pobreza.

Os adolescentes que cometem ato infracional demonstram com seus atos o quanto não foi possível para as pessoas enxergá-los antes de cometerem uma infração. 
Pela perversa relação inclusão-exclusão que permeia a sociedade capitalista, ele se torna incluído quando passa a assumir o

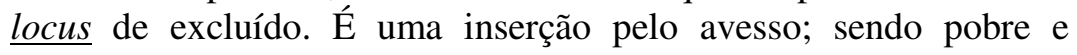
destituído de valor, passa a ter valor como abandonado ou como infrator, pois só assim consegue espaço para se inserir socialmente. (CALIL. 2003. p. 159-160)

Sua revolta individual faz aparecer questões sociais como o desenraizamento que ocorre pela necessidade de inclusão na lógica do capital para acúmulo de bens e serviços; as relações sociais desgastadas pela lógica egoísta necessária ao desenvolvimento do capitalismo; a necessidade de obtenção de objetos que, carregados de desejo, promovem a sensação de valorização pessoal, mas que na verdade depreciam o ser humano, coisificando-o.

A violência dos adolescentes é a reprodução da violência sofrida pela desumanização, coisificação e massificação provocada pela sociedade de consumo que o sistema capitalista de produção promove. O capitalismo é muito mais que um sistema econômico, ele delineia uma forma de existência.

José de Souza Martins, em "O modo capitalista de pensar" (1980. p.ix), afirma:

Entendo que o modo capitalista de produção, na sua acepção clássica, é também modo capitalista de pensar e deste não se separa [...] $O$ modo capitalista de pensar, enquanto modo de produção de idéias, marca tanto o senso comum quanto o conhecimento científico. Define a produção das diferentes modalidades de idéias necessárias à produção das mercadorias nas condições de exploração capitalista, da coisificação das relações sociais e da desumanização do homem. Não se refere estritamente ao modo como pensa o capitalista, mas ao modo de pensar necessário à reprodução do capitalismo, à reelaboração das suas bases de sustentação - ideológicas e sociais.

A condição econômica - a pobreza - agrava, mas não é responsável pelo cometimento de infrações, vide o número elevado de jovens das classes média e alta envolvidos com atos infracionais. O modo capitalista de pensar perpassa todas as classes sociais e, portanto, a desumanização e a coisificação produtoras de violência estão promovendo a socialização de todos os jovens. 
A pesquisa acadêmica deve promover o esclarecimento dos envolvidos, dar voz aos oprimidos e não produzir, ou reafirmar, preconceitos com bases científicas. É preciso tomar cuidado, pois:

[...] O conhecimento significa poder, e o serviço que certos modos de pensar prestam ao exercício do poder social transformamnos em "verdades" que o próprio poder torna inquestionável [...] A ciência justificou e deu aval à prática iníqua que condenou milhões de homens à escravidão [...] a exclusão sempre se fez acompanhada de justificativas que afirmam princípios de sanidade mental no caso dos loucos e/ou princípios de ordem social no caso de outros excluídos - os vagabundos, os mendigos, os subversivos. (MELLO. 2001. p. 81-82).

Essa pesquisa pretendeu dar voz aos adolescentes que cometeram atos infracionais. O que os jovens estão querendo dizer quando cometem uma infração?

A fala a seguir expõe a importância da pesquisa crítica:

Ao justificar a produção social da delinqüência pela estrutura psíquica, pela hereditariedade, e pela família (desestruturada), ocultam-se suas origens históricas, sociais e políticas. Dessa forma, por meio dessas justificativas legitima-se a desigualdade social e a violência, desconsiderando-se as inúmeras relações existentes nesse processo. [...] O jovem, dessa forma, deve ser compreendido em conexão com a história da sociedade. (FEFFERMANN. 2006. p. 185)

Nenhum mecanismo individual ou social promove, sozinho, a delinquiência; nenhum comportamento humano pode estar baseado em premissas do tipo "se isso, então aquilo", causa e efeito, sim e não. Não há histórias de vida típicas que derivem para a delinqüência. Para o adolescente cometer uma infração houve uma seqüência de rupturas.

Certas condições não podem ser previstas e, portanto, não devem produzir práticas higienistas.

Não há uma trajetória biográfica típica que derive para a delinqüência, ao contrário do que apregoam certas tendências na literatura, inspiradas em teses criminológicas discutíveis, que elegem a desorganização familiar, a pobreza, a baixa escolaridade, a falta de profissionalização, a intermitência no trabalho como estímulos à construção de uma carreira no crime. De fato, a derivação para a delinquiência pode estar associada a tais situações, estar associada a 
algumas delas combinadas entre si, ou a nenhuma delas. (ADORNO. 1993. p.194)

Vicentin (2005. p. 213) utiliza-se de diversos autores para concluir que o ato infracional tem inúmeros significados e está atravessado por diversas questões sociais: ética do trabalho versus ética da malandragem; insubmissão, contestação, denúncia; humildes filhos de trabalhadores pobres versus corajosos "ladrões"; manutenção dos padrões sociais aceitáveis para a ocorrência de crimes, sem ameaças à ordem econômica etc. Vicentin chama os atos infracionais de "hiper-realismo" como uma estratégia de sobrevivência para não desaparecer. Acredita também que ele seja uma excelente estratégia de comunicação que se conecta perfeitamente aos modos midiáticos/performáticos contemporâneos de aparecer.

A sociedade capitalista impõe ao sujeito a necessidade de obtenção de objetos para sentir-se valorizado. É como se fosse comprar a felicidade com a obtenção e ostentação de mercadorias.

Adolescentes pobres, excluídos que estão da possibilidade financeira de aquisição desses objetos, quando os arrancam de um outro ser, rompem o pacto social de respeito à propriedade privada, e às vezes, o respeito à própria vida, para obtenção desses objetos e sensação de valorização pessoal e social.

Quando isso acontece, eles revelam a contradição social - existência de pobres, para que outros sejam ricos - de uma maneira perversa. Não resolvem a contradição, atuam sobre ela, negam ao outro a possibilidade de posse, arrancando-lhe o objeto de desejo. O poder de fetiche da mercadoria exerce sobre ele um poder desumanizador.

“[...] Pouco compreendendo os determinantes da injustiça social, mas sentindo na pele suas decorrências, adolescentes podem querer resolver a contradição social da qual vivem os efeitos, pela transgressão de um dos mais caros preceitos dessa sociedade que os oprime." (ROMAN. 2007. p.230)

Certa vez, na Associação Novolhar, realizei uma atividade com os adolescentes que freqüentavam o curso de vídeo-produção. Eram todos 
moradores das periferias da cidade de São Paulo. Alguns haviam cometido atos infracionais e estavam cumprindo uma medida socioeducativa. Eles tinham que pensar como estaria sua vida dali a dez anos. Todos - moças e rapazes - responderam com desejos semelhantes: queriam morar em uma boa casa, possuir um carro do ano, estar casados e ter vários filhos.

Esse sonho era de cada um, mas também de todos os jovens pobres. Esse sonho coletivo demonstrou o que foi ensinado aos jovens, desde que eram crianças: para serem felizes é necessário obter bens e mostrá-los aos outros. Para alguns jovens, alcançar esse sonho significa colocar sua vida em risco. Para outros, resta a resignação de continuar tentando e percorrer um longo caminho onde poucos conseguem chegar - a riqueza material. Não por demérito individual, mas por força da própria engrenagem social.

Essa pesquisa partiu de concepções teóricas que afirmam que o indivíduo constitui-se em uma relação dialética com a sociedade em que vive, e que a vida dos adolescentes é mediada pelo contexto histórico-social da humanidade.

Esse trabalho teve o objetivo de discutir a prática infracional de adolescentes como uma conseqüência do impedimento da constituição do humano na sociedade atual.

Teve também o objetivo de dar voz aos adolescentes para ir além das aparências e do senso comum. Ouvi-los para transformá-los em agentes de sua própria história.

Pretendeu contribuir para que a universidade assuma um de seus importantes papéis: o de oferecer conhecimentos a serviço do enfrentamento de graves questões sociais.

Para dar conta desses objetivos foi importante buscar um referencial teórico-crítico de homem, de mundo e de psicologia social, enfocando a história da sociedade ocidental em relação à possibilidade de formação/constituição do ser humano. Tornou-se fundamental compreender 
quem é esse jovem que vive em nossa sociedade, quais suas expectativas e necessidades, quais condições estão proporcionando a formação desse sujeito.

À psicologia cabe entender como a vida particular dos indivíduos influencia e sofre as influências (dialeticamente) do contexto histórico-cultural da humanidade.

Por mais que verifiquemos o poder de determinação da estrutura social, a psicologia se coloca em um nível de análise que demonstra a singularidade com que os sujeitos se apropriam das circunstâncias dadas para satisfazerem suas necessidades. Nesse nível, as relações entre os sujeitos carregam simultaneamente algo de reprodução da estrutura social, mas também de recriação, ineditismo, potência de ruptura e de desenvolvimento humano. (ROMAN. 2007. p. 77)

Essa ciência tem um importante papel no desenvolvimento de teorias (produção de conhecimento) e de práticas que contribuam para a promoção de indivíduos emancipados e conscientes de sua condição humana. Conscientes também da estrutura econômica e política da sociedade em que vivem, detentores dos conhecimentos elaborados pelo homem na história da humanidade, sujeitos de sua própria vida.

A partir dos conhecimentos produzidos por essa pesquisa, acredito que os psicólogos poderão ter uma atuação profissional mais próxima das necessidades do adolescente que cometeu um ato infracional e poderão contribuir para que os próprios jovens, suas famílias e a sociedade em geral construam saídas coletivas para uma questão que é de todos nós.

Para que todos possam enfrentar esse fenômeno é preciso compreendêlo. É necessário produzir um conhecimento responsável, crítico, comprometido com a possibilidade de transformação, não de encarceramento. 
Capítulo 3 - A DISTÂNCIA NECESSÁRIA - A PESQUISA 


\section{A DISTÂNCIA NECESSÁRIA - A PESQUISA}

Qual a metodologia de trabalho investigativo mais pertinente possível para capturar um objeto em movimento, em construção, um objeto "vivo" que produz novos e complexos acontecimentos no mundo das relações que o transmutam? Como capturar um objeto que se constrói recíproca e ininterruptamente porque articulado, imbricado com todos os aspectos da vida social? Quais os procedimentos para circunscrever este objeto que revela a si e àquilo que está para além de sua circunscrição, que reverbera? (TRASSI. 2006. p. 19)

A questão dos adolescentes que cometem atos infracionais não pode ser entendida como um fenômeno simples.

Para não reduzir um fenômeno tão complexo, o seu estudo exige o encontro de várias áreas do conhecimento como sociologia, história, psicologia, pedagogia, direito etc. A visão microscópica é necessária - o indivíduo, sua história pessoal. Mas também uma visão mais ampliada do fenômeno - as condições sociais, o encontro do individual com o social.

A biografia e os dados estatísticos são complementares para a análise da questão proposta por essa pesquisa.

[...] o caso particular, o detalhe de uma biografia não detectado em uma pesquisa estatística, acaba por demonstrar aspectos das práticas e formas de relação social que podem conduzir à apreensão das transformações do fenômeno. Os dados estatísticos, ao mesmo tempo, auxiliam na contextualização do fenômeno na sociedade. (TRASSI. 2006. pp. 19-20)

Pela leitura do texto The Paradigm Dialog, de E. G. Guba (1990) e as discussões realizadas na disciplina de pós-graduação intitulada "Pesquisa Científica em Psicologia Social: Abordagens, Métodos e Técnicas”, acredito que essa pesquisa insere-se, prioritariamente, dentro do paradigma da Teoria Crítica.

Para Guba (1990), a ciência produzida a partir desse paradigma é uma ação política, tem como fundamento a idéia de uma sociedade emancipada, o desvendamento e desvelamento dos sujeitos e a conseqüente transformação social. 
Estudar sobre adolescentes que cometem ato infracional foi uma escolha que se deu a partir de uma prática comprometida com a emancipação desses jovens. Desde a escolha do meu objeto, a própria pesquisa e a divulgação de seus resultados - todo esse processo - foi uma ação política.

O diálogo com os jovens que aceitaram participar da pesquisa foi estabelecido de acordo com o pressuposto da emancipação do sujeito: esclarecimento sobre o objetivo da pesquisa, diálogo sobre a importância da sua visão dos fatos, discussão sobre a escolha em participar ou não da pesquisa, a leitura posterior do texto obtido a partir da transcrição da fala que foi enviada aos jovens para que eles modificassem o que achassem necessário.

A pesquisa carregou a intenção de trabalhar para a identificação, desvelamento dos sujeitos e transformação dessa sociedade que produz esse fenômeno - adolescentes que cometem atos infracionais. O resultado pretendeu mostrar a importância do esclarecimento dos adolescentes, dos psicólogos e demais profissionais que desenvolvem atividades com esse público.

Segundo Guba (1990), a Teoria Crítica deve questionar e explicitar os seus próprios fundamentos - conceitual e metodologicamente. Nesta pesquisa foi importante explicitar os conceitos de adolescência, violência, fetichismo da mercadoria, possibilidade de constituição do humano em cada um e o papel da mídia nessa sociedade. $\mathrm{O}$ autor afirma que a Teoria Crítica partilha, ontologicamente, de um realismo crítico, ou seja, deve ocorrer um questionamento de verdades externas ao sujeito - no caso da minha pesquisa, o fato de muitas pessoas afirmarem que a prática infracional é um fenômeno individual, praticado por indivíduos autônomos.

Também foi importante questionar e esclarecer a relação que se estabelece entre o pesquisador e o adolescente que cometeu ato infracional. A relação de pesquisa é assimétrica e deve ser sempre discutida.

Da escolha do objeto e dos sujeitos, da teoria envolvida na discussão até a metodologia para obtenção dos resultados, há presença de valores do 
pesquisador. Levar em consideração e trabalhar com esses valores é um outro pressuposto do paradigma da Teoria Crítica.

Para se fazer isso devem ser explicitados os modos de pensar, entender e questionar o mundo à nossa volta - o texto The Paradigm Dialog (GUBA. 1990) define essa epistemologia como subjetivista. A metodologia é dialógica e transformadora; a ação, conseqüentemente, deve buscar a autonomia e a emancipação dos sujeitos e a transformação da sociedade.

Acredito que, no caso da minha pesquisa, a metodologia também é hermenêutica e dialética, pois as construções individuais foram extraídas e refinadas a partir da análise dos textos obtidos na transcrição das entrevistas. As idéias contidas nessas falas foram analisadas e discutidas dialeticamente com a teoria e com as demais fontes de evidência coletadas.

Enfim, o cuidado de explicitar a teoria usada na análise, a escolha do objeto de pesquisa, dos sujeitos envolvidos e da discussão dos resultados são fundamentos importantes para uma pesquisa que se pretende esclarecedora e transformadora de uma certa realidade. Esse foi o pressuposto fundamental da pesquisa que desenvolvi.

Como foi indicado no capítulo anterior, a pesquisa pretendeu analisar o ato infracional: quem são, como vivem e o que pensam os adolescentes autores de atos infracionais? O que o ato infracional de adolescentes está mostrando? Como os jovens conseguiram sair da vida criminal?

A partir dessas questões e pelo fato do ato infracional de adolescentes ser um fenômeno multideterminado, em que várias circunstâncias convergem, de maneira dialética e não linear, para o seu engendramento, foi possível definir o método de pesquisa como sendo o de Estudo de Caso.

Yin (2001. p.19) propõe a seguinte definição para esse método: “[...] os estudos de caso representam a estratégia preferida quando se colocam questões do tipo "como" e "por que", quando o pesquisador tem pouco controle sobre eventos e quando o foco se encontra em fenômenos contemporâneos inseridos em algum contexto da vida real." Portanto, a metodologia de pesquisa 
escolhida auxiliou na compreensão de um fenômeno social complexo como o ato infracional de adolescentes.

Os estudos de caso promovem uma pesquisa que pode ser generalizável para proposições teóricas e não para populações ou universos. Assim, o meu objetivo, ao escolher essa metodologia, foi de expandir e generalizar teorias e não enumerar freqüências. As teorias que comumente tentam analisar o ato infracional de adolescentes partem de pressupostos unicamente individuais ou sociais. Essa pesquisa pretendeu pensar o fenômeno no entrecruzamento do individual com o social.

Apontando a necessidade de que a investigação de um estudo de caso exige a coleta de dados por meio de várias fontes (YIN. 2001. p.107 e seguintes) e que essas devam convergir para que ocorra um encadeamento das evidências, foram utilizadas quatro fontes de evidências: análise documental, registros em arquivos, entrevistas, observação direta.

A análise documental foi um importante resgate sobre a história das leis que lidam com a infância e juventude no Brasil, além de uma análise sobre a mídia brasileira e latino-americana quando o assunto envolvia crianças e adolescentes.

A análise histórica sobre o tema foi fundamental para o entendimento da constituição do fenômeno na atualidade. Nesse levantamento, a apresentação das leis que tratam sobre a questão, especificamente a passagem do Código de Menores para o Estatuto da Criança e do Adolescente (ECA) e o Sistema Nacional Socioeducativo (SINASE), tornou-se necessário.

A leitura crítica dessas leis demonstrou como a sociedade brasileira entende esse fenômeno, como lida atualmente e como lidou no passado. Entender o processo histórico de constituição do "problema" auxilia no desvendamento das forças que o engendram e constituem.

Os documentos puderam auxiliar na compreensão do fenômeno, corroborando informações coletadas pelas entrevistas com os jovens, indicando alguns pontos a serem analisados e aprofundando o conhecimento sobre o tema. 
Outros documentos importantes foram os relatórios produzidos pela Agência de Notícias dos Direitos da Infância - ANDI.

A ANDI produz relatórios que analisam o comportamento da mídia brasileira e latino-americana quando o assunto é a infância e a juventude. Para tanto, cerca de 50 jornais impressos são acompanhados diariamente. As inserções sobre crianças e adolescentes são catalogadas, separadas por assunto e analisadas segundo critérios construídos para esse fim.

Conhecer como a imprensa lida com a questão da infância e adolescência brasileira, como expõe as determinações legais sobre o tema (análise do ECA), como as políticas públicas sobre infância e adolescência são consideradas na compreensão do fenômeno, por que algumas propostas de mudança da legislação estão em curso no Congresso Nacional auxilia o entendimento de como a sociedade - trabalhadores da área ou não - lida com essa questão.

Registros em arquivos: foram analisadas estatísticas sobre o perfil dos adolescentes que cometeram atos infracionais e cumpriram medida socioeducativa na Febem - SP e estatísticas sobre as violências cometidas e sofridas por adolescentes e jovens.

Essas informações ajudaram a conhecer o perfil do adolescente que cometeu um ato infracional e cumpriu medida socioeducativa na Febem de São Paulo: idade, sexo, escolaridade, trabalho, moradia, informações sobre sua família. Auxiliaram também a jogar luz sobre o fato de que a violência cometida por adolescentes segue o mesmo padrão da violência cometida por adultos, além de mostrar que os adolescentes são vítimas de violência, tanto quando são alvo, como quando são autores de um ato violento.

Entrevistas com jovens que cometeram atos infracionais na adolescência.

No início da pesquisa a proposta era coletar informações através de três tipos de entrevistas: entrevistas individuais com jovens que tivessem cometido 
infrações; entrevistas com seus familiares; uma entrevista coletiva com os adolescentes que participaram da pesquisa.

Após a realização de entrevistas individuais com quatro diferentes jovens, o material agrupado já era grande e suficiente para promover a discussão proposta por essa dissertação, fato que fez com que a idéia original fosse alterada.

Assim, com os jovens, o método de coleta de dados denominado História Oral demonstrou ser apropriado. De acordo com Freitas (2002. p.15) esse método "[...] possibilita reflexões sobre o registro dos fatos na voz dos próprios protagonistas." Os relatos orais captam informações originais do sujeito que jamais seriam conquistadas de outra forma.

Para se realizar entrevistas é fundamental que o pesquisador tenha um conhecimento prévio sobre o assunto em questão. Minha experiência profissional anterior contribuiu e facilitou no desenrolar das entrevistas e na sua posterior análise.

Cada um dos quatro jovens forneceu um único depoimento. Os encontros duraram, no geral, pouco mais de uma hora cada um.

O principal assunto da entrevista - o fato de eles terem cometido ato infracional - foi escolha do pesquisador e as questões específicas foram sendo colocadas durante os depoimentos a partir das falas dos jovens, caso eles próprios não abordassem o tema espontaneamente.

Nas entrevistas, o interessante foi o jovem discorrer sobre sua vida: sua família, idade, onde morava, como era freqüentar a escola, quais suas experiências de trabalho e geração de renda, o que fazia para se divertir, o que leva um adolescente a cometer um ato infracional e o que leva a deixar de praticar infrações e, conforme o caso, como se deu o cumprimento de uma medida socioeducativa.

Os encontros com os jovens tiveram início com uma explicação sobre a pesquisa e o motivo pelo qual eu gostaria que eles participassem, além de um 
pedido de permissão para que a conversa fosse gravada. O convite para participar da entrevista já havia sido feito por telefone.

Todos os depoimentos começaram com um pedido do pesquisador para que o jovem contasse sobre sua vida: qual sua idade; onde tinha nascido; informações familiares; informações sobre escolaridade e trabalho etc.

Assim, todos começaram um relato livre sobre sua história de vida, desde sua infância até chegar ao momento atual. Sempre que possível, a interferência do pesquisador ocorreu apenas para clarear informações. O período em que cometeram atos infracionais e o cumprimento da medida socioeducativa foi relatado livremente, sem o uso de perguntas fechadas.

A relação que esse jovem estabeleceu entre a sua história de vida e a experiência de ter cometido um ato infracional proporcionou a fonte para discussão do cruzamento do social com o individual e promoveu, no diálogo com a teoria, o entendimento do engendramento desse fenômeno.

A importância do material colhido a partir dos depoimentos orais não se dá pela "verdade" ou "falsidade" das informações, mas sim pela forma como aquele indivíduo vivenciou experiências que, apesar de únicas, são sempre coletivas. Queiroz (1988. p. 21) afirma que "[...] O crédito a respeito do que é narrado será testado, não pela credibilidade do narrador, mas sim pelo cotejo de seu relato com dados oriundos de outras fontes, que mostrará sua convergência ou não."

As experiências falam de um tempo histórico, de uma determinada classe social, a partir de um espaço geográfico na cidade, de comportamentos e valores, de ideologias que perpassam a forma de vida e a cultura do grupo ao qual pertence o depoente.

Observação direta durante os anos de trabalho com adolescentes pobres e/ou que cometeram atos infracionais.

A observação direta em períodos anteriores à pesquisa formal serviu para o resgate de alguns eventos que proporcionaram informações coletadas diretamente sobre o fenômeno em estudo. 
O trabalho com os adolescentes que cometeram atos infracionais - em sala de aula; nas ruas do centro da capital ou nos bairros periféricos da cidade (local de moradia de uma grande parcela dos adolescentes que cometem atos infracionais); em unidades da Febem para o cumprimento das medidas socioeducativas de internação ou semiliberdade; em espaços públicos para o acompanhamento de atividades culturais de interesse dos jovens etc. contribuiu para conhecer muitos jovens, alguns familiares desses adolescentes, sua forma de pensar e agir. Essas impressões pessoais foram utilizadas com cuidado e sempre que possível, com registro minucioso do evento citado.

"Qualquer atuação que se queira responsável e consistente deve ser acompanhada por um grau considerável de conhecimento a respeito do contexto em que se insere, de modo que atuação profissional e pesquisa nunca devem ser separadas.” (ROMAN. 2007. p. 89)

Para a discussão deste trabalho optei por inserir trechos das falas dos jovens entrevistados. A transcrição da fala do sujeito permite que o leitor entre em contato com as idéias oferecidas pelo próprio entrevistado, permite que o leitor possa conhecer o outro, mesmo que a escolha dos trechos usados seja feita pelo pesquisador.

Quando o pesquisador faz uso do texto transcrito, ele utiliza os relatos a partir de sua forma de pensar e organizar a fala do outro. As partes selecionadas foram escolhidas de acordo com o interesse desta pesquisa; por isso, para que o leitor tenha contato com o material inteiro, sem recortes ou organizações do pesquisador, a transcrição literal consta dos anexos desta dissertação.

As entrevistas e as transcrições foram feitas pela própria pesquisadora, o que já garantiu uma aproximação com as falas dos jovens. O material escrito foi lido e relido diversas vezes. Diversas "escutas” foram necessárias.

Em uma primeira leitura houve uma aproximação do conteúdo e num segundo momento houve separação dos temas presentes em cada uma das entrevistas. Uma terceira leitura foi importante para marcar trechos que 
chamaram a atenção nas falas. Na quarta leitura foi realizada uma construção de categorias. A partir de novas leituras deu-se o processo de análise das entrevistas. Essas foram desorganizadas e separadas em dois tópicos principais, que denominei "violências" e "resgate".

As histórias dos jovens não foram contadas, evidentemente, seguindo uma seqüência linear ou temporal dos acontecimentos. Os assuntos foram separados de maneira a facilitar a análise do pesquisador, sempre respeitando o ponto de vista do entrevistado.

Os depoimentos dos jovens foram muito importantes e a análise do material, entrecruzada com a teoria, enriqueceu esta pesquisa. A análise significa "[...] decompor um texto, fragmentá-lo em seus elementos fundamentais, isto é, separar claramente os diversos componentes, recortá-los, a fim de utilizar somente o que é compatível com a síntese que se busca." (QUEIROZ. 1988. p.19)

Entrevistador e depoente possuem responsabilidades um com o outro. Esse não deve ser um encontro efêmero, dotado de interesses subentendidos. Os objetivos da pesquisa foram explicitados e debatidos com o entrevistado. Suas razões e disponibilidade para participar da pesquisa também precisaram ser discutidas e clareadas.

O fato de eu trabalhar com esse público há anos permitiu uma aproximação entre entrevistador e depoente; porém, a distância social que nos separa foi levada em consideração. Os dois entraram para essa relação como sujeitos conscientes, inclusive da posição de ambos na pesquisa.

A relação da entrevista é uma relação social e as relações historicamente construídas entre ambos foram consideradas. Não se pode omitir as diferenças ou fingir que elas não existem.

Deve-se "[...] perceber e controlar no campo, na própria condução da entrevista, os efeitos da estrutura social na qual ela se realiza [....]. Principalmente esforçando-se para [...] controlar os efeitos da própria pesquisa 
e começar a interrogação já dominando os efeitos inevitáveis das perguntas." (BOURDIEU. 1999. p. 694)

Às vezes o entrevistado pode dizer aquilo que ele acha que o pesquisador quer ouvir. Para minimizar essa possibilidade, procurei entrevistar jovens que já me conhecessem. Dessa forma, o estabelecimento do vínculo de confiança necessário para que a entrevista ocorresse livremente se estabeleceria com mais facilidade.

Para a escolha dos jovens entrevistados algumas questões foram ponderadas a fim de facilitar o desenvolvimento da conversa:

- Encontrar jovens que eu já conhecesse e que tivessem cometido infrações na adolescência;

- No momento da entrevista os jovens deveriam ter mais de 18 anos e já terem cumprido sua medida socioeducativa, sem nenhum vínculo com a Febem. Dessa forma eles estariam mais afastados da experiência, podendo retomá-la através da memória;

- Eles, necessariamente, deveriam querer participar da pesquisa.

Na tentativa de encontrar esses jovens, procurei a Associação Novolhar, instituição onde eu havia trabalhado de 2000 a 2002 e que poderia me auxiliar a encontrar alguns jovens com o perfil acima. O coordenador do Novolhar passou-me os contatos de Alex, Lucas e Breno.

Liguei para Alex convidando-o para a entrevista. Relembramos os tempos em que ele foi aluno do Novolhar e expliquei que o coordenador havia me passado o seu contato. Relatei também qual era a pesquisa e o meu interesse em ouvi-lo, incentivando-o a contar sua vida e experiência infracional. Marcamos de nos encontrar no seu local de trabalho. Com sua permissão a entrevista foi gravada, transcrita e posteriormente enviada a ele por e-mail para que fizesse qualquer sugestão ou alteração em sua fala.

O caminho até Lucas foi semelhante ao descrito para encontrar Alex, com a diferença de que a entrevista foi realizada nas dependências do 
Novolhar. Lucas também permitiu que sua entrevista fosse gravada e posteriormente transcrita e enviada por e-mail para que ele efetuasse sugestões ou modificações em sua fala.

Para contatar Breno liguei para seu celular diversas vezes. Em todas elas atendeu a secretária eletrônica; então, resolvi deixar recado me identificando e deixando telefones de contato para que ele retornasse a ligação. Enviei, além disso, um e-mail explicando a pesquisa e apresentando o meu interesse em conversar com ele.

Sem retorno, entrei novamente em contato com o Novolhar para verificar se o número do telefone estava correto, pois a secretária eletrônica do celular não tinha identificação. Tive a sorte de Breno estar no Novolhar no momento da minha ligação. Falamos ao telefone, expliquei a pesquisa e o meu interesse em conversarmos. Ele não se lembrou de mim e não quis marcar nenhum compromisso. Ficou de entrar em contato quando nossa conversa fosse possível.

No dia seguinte ele me ligou e agendamos para nos encontrarmos no Novolhar. Logo que nos vimos percebemos, eu e ele, que não nos conhecíamos. Ele tinha freqüentado o Novolhar anos antes de eu trabalhar na instituição.

Convidando-o para a entrevista, expliquei a pesquisa de mestrado, quem eu era, o que fazia, qual o meu percurso profissional e propus sua participação, apesar do fato de não nos conhecermos. Breno consentiu e nos dirigimos para a sala onde se guardam os equipamentos de gravação da Produtora Novolhar. A escolha dessa sala deveu-se ao fato de que não seríamos incomodados, pois é uma sala pouco utilizada. Ela estava toda arrumada e limpa, só precisamos buscar cadeiras. Breno incomodou-se um pouco com os cabos que estavam pendurados e organizados em um painel, mas mesmo assim aceitou estar naquela sala, desde que as janelas fossem abertas, o que ocorreu. 
Breno permitiu que a entrevista fosse gravada e transcrita. Posteriormente foi enviada por e-mail para sugestões ou modificações que achasse necessárias.

A entrevista com Breno foi a mais difícil. Ele parecia muito desconfiado, sendo evasivo nas respostas. Em alguns momentos cheguei a perguntar se ele realmente queria continuar a entrevista, pois não era necessário se não quisesse. Acredito que essa dificuldade no estabelecimento de um vínculo de confiança tenha ocorrido em parte porque não nos conhecíamos, em parte por características pessoais do jovem (como pode ser observado na entrevista) e também porque o assunto tratado era de caráter muito pessoal.

Pela dificuldade de contatar outros adolescentes que já haviam passado por cursos no Novolhar e que me conhecessem, procurei a coordenadora de um Núcleo Socioeducativo ${ }^{9}$ (já nos conhecíamos porque eu havia trabalhado em outro núcleo da mesma instituição) e solicitei a ela que convidasse algum jovem que tivesse cometido algum ato infracional na adolescência. Douglas foi convidado pela coordenadora dessa instituição. Ele não me conhecia, mas aceitou participar da pesquisa. Sua entrevista foi concedida nas dependências da Associação Mutirão. Ela foi gravada e posteriormente transcrita, impressa e enviada a ele para possíveis modificações.

Apesar de não nos conhecermos, a entrevista com Douglas fluiu muito bem. Ele dizia que queria contar sua experiência para poder ajudar outras pessoas a não passarem por situações semelhantes. Acredito que tenha sido com esse argumento que a coordenadora do Mutirão o convidou para a entrevista. Estávamos os dois bem à vontade.

No decorrer da entrevista percebi que Douglas havia cometido infrações na adolescência, mas só havia sido preso depois de adulto. Douglas não cumpriu medida socioeducativa. Naquele momento ele ainda cumpria pena no sistema prisional adulto. Resolvi manter sua entrevista pela riqueza

\footnotetext{
${ }^{9}$ Associação Mutirão do Pobre, localizada na Zona Norte de São Paulo.
} 
das informações obtidas. Além disso, sua experiência mostrou-se semelhante à dos outros jovens entrevistados.

Todos os jovens entrevistados cometeram infrações na adolescência. Alex, Breno e Lucas foram julgados e tiveram que cumprir medidas socioeducativas, respectivamente de: internação e liberdade assistida; internação, semiliberdade e liberdade assistida; prestação de serviços à comunidade na Febem SP. Douglas, conforme exposto acima, foi preso e condenado depois de adulto, fato que fez com que cumprisse pena no sistema penitenciário.

Certa vez, em conversa com um jovem que cumpria uma medida socioeducativa de semiliberdade, ele me disse: "a palavra da senhora faz curva!"

"Há palavras que, de tão atraídas pelas convenções dos discursos diários e pelos preconceitos de classe, já não nos fazem pensar mais." (GONÇALVES FILHO, 1995, p.7) Foi assim que aquele jovem entendeu a minha fala!

O encontro com esses jovens e seus discursos nos coloca a pensar - a palavra da senhora faz curva? Que susto! Ele dizia que a minha palavra "não seguia pelo reto", não tinha coerência. Tudo que eu não queria tinha acontecido. Eu sentia e desejava transmitir respeito, coerência. Quem vai contar algo para outro a quem a palavra faz curva? 
Capítulo 4 - OS ADOLESCENTES JULGADOS AUTORES DE ATOS INFRACIONAIS 


\section{OS ADOLESCENTES JULGADOS AUTORES DE ATOS INFRACIONAIS}

A concepção de infância como uma das estações da vida, alegre e despreocupada, com seus folguedos e sua liberdade, e a juventude como o tempo de experimentação e turbulência, ambos definidos como período de inteligência e da espontaneidade generosa... [...] No entanto, ela está marcada pela história e pela posição de classe, longe do valor universal que a ela se quer atribuir. Essa concepção é normativa, diz o que deveria ser e não como é, de fato, vivida a infância e a juventude para a grande maioria dos jovens no Brasil. (MELLO. 2001. p. 84)

A revolta consiste, portanto, na confrontação desesperada da interrogação humana frente ao silêncio do mundo. Nasce assim, do espetáculo da desrazão, diante de uma condição injusta e incompreensível. Porém, paradoxalmente, como paixão cega, reivindica a ordem em meio ao caos [...] ultrapassando o tempo do silêncio, a revolta é julgamento e desejo, assim como portadora de valores, que [...] ultrapassam o indivíduo em si. Leva-o afinal mais longe que a simples recusa inicial da ordem. (SALES. 2004. pp. 258-259)

\subsection{A Adolescência}

Os conceitos de infância e adolescência são construções culturais que revelam o modo como as pessoas de determinada cultura organizam e reproduzem as condições materiais de existência.

Calil (2003) afirmou que o conceito de adolescência surgiu no século XIX apresentado por Rosseau em "Emílio ou da Educação". No fim do mesmo século a psicanálise marcou o conceito como um período em que o indivíduo vive "[...] um intenso sentimento de luto e uma imensa angústia, enfatizando o conflito pais e filhos, resultante das dificuldades, necessidades e mudanças do adolescente, como um aspecto importante desta turbulência emocional." (CALIL. 2003. p.144).

A adolescência é uma produção da sociedade ocidental a partir do século XX e desde então, as formas de ser adolescente já mudaram muito. 
Diferentes teorias psicológicas enfatizaram a adolescência como um período de crise turbulenta e confusa, natural, universal e necessária para o desenvolvimento do ser humano. As teorias psicanalíticas são responsáveis pela popularização da adolescência como um período de crise no indivíduo.

Veja a fala de Evaristo de Moraes, em texto do início do século XX, reveladora do modo como teorias naturalizantes podem transformar um indivíduo em criminoso (MORAES. 1927. pp. 25-26):

"Dadas estas características essenciaes da alma do adolescente - a instabilidade, ou mobilidade, e a intensidade dos sentimentos - é bem de ver que a ellas deve corresponder uma criminalidade especial."

Os estudos de Margaret Mead (1933) relatam a existência de culturas diversas onde a passagem da criança para a vida adulta é vivida de forma diferente. Com ela foi possível pensar a adolescência a partir de aspectos culturais e não um período vivido universalmente como uma crise turbulenta e necessária para a constituição do indivíduo adulto.

Ozella (2003) em "A adolescência e os psicólogos: a concepção e a prática dos profissionais" realizou um resgate das concepções de adolescência para os profissionais de psicologia e para autores clássicos sobre o assunto (Osório e Aberastury ${ }^{11}$ ) e apontou que a naturalização e a patologização de uma fase da vida do indivíduo permeiam os discursos ainda hoje.

Algumas expressões são usadas para definir a adolescência a partir de concepções naturalizantes: fase universal, crise, turbulência, síndrome normal.

Trassi (2006. p. 211 e seguintes) faz um levantamento das principais concepções de adolescência para a psicologia para definir esse como um tema polêmico. Baseada em diversos autores afirma que o início da adolescência é determinado pelas mudanças biológicas que ocorrem com o advento da

\footnotetext{
${ }^{11}$ Osório, L. C. Adolescente hoje. Porto Alegre: Artes Médicas. 1989 e Aberastury, A. Adolescência. Porto Alegre: Artes Médicas. 1980.
} 
puberdade. Isso é um consenso para diversas especialidades: medicina, psicologia, antropologia. ${ }^{12}$

Winnicott levanta o aspecto fundamental desse período: a adolescência é "[...] essencialmente um período de descoberta pessoal. Cada indivíduo está empenhado numa experiência vital, um problema de existência, e de estabelecimento de uma identidade.” (2005. p. 163). Buscar o seu espaço no mundo implica em encontrar figuras de identificação, modos de ser e de agir.

Acredito que a adolescência não é uma fase natural do intervalo entre ser criança e ser adulto, nem tampouco é vivida de maneira universal como definem as teorias naturalizantes. É um período da vida constituído social e culturalmente. Cada grupo vive um processo de descobertas das possibilidades de inserção no mundo adulto de acordo com necessidades determinadas pela sua condição econômica, social e cultural. A adolescência é um processo histórico e cultural.

"[...] existem "adolescências", que vão se constituir a partir do contexto social, histórico, econômico e político, entre outros, nos quais os sujeitos adolescentes estiverem inseridos [...]" (VIEIRA. 2003. p. 91)

$\mathrm{O}$ adolescente tem que lidar com as mudanças advindas da puberdade. O modo como ele lida com elas baseia-se em padrões que vão se estabelecendo desde a infância. No desenvolvimento do adolescente o papel desempenhado pelo meio social e cultural em que vive tem fundamental importância.

$\mathrm{O}$ adolescente busca uma forma de ser e de agir. Na tentativa de encontrar o seu espaço no mundo adulto ele está vulnerável às propagandas e modismos de sua época, cultura e classe social. Ele imita comportamentos, tem sonhos e desejos para o futuro, tenta ser igual ou diferente aos padrões estabelecidos na sociedade em que vive. Busca descobrir a si mesmo no mundo.

\footnotetext{
${ }^{12}$ G. Stanley Hall (1844-1924); Margaret Mead (1933); Erik H. Erikson (1968); Aberastury (1981); José Outeiral (1998); Françoise Dolto (1990); Contardo Calligaris (2000).
} 
Esse é um período vivido de formas diferentes por diferentes grupos culturais. Não é uma fase natural e biológica, é historicamente constituída:

Como afirma Ozella (2002.p.21):

[...] a adolescência é criada historicamente pelo homem, enquanto representação e enquanto fato social e psicológico. É constituída como significado na cultura, na linguagem que permeia as relações sociais [...] A adolescência não é um período natural do desenvolvimento. É um momento significado e interpretado pelo homem [...] o jovem não é algo por natureza. São características que surgem nas relações sociais, em um processo no qual o jovem se coloca inteiro, com suas características pessoais e seu corpo.

Como qualquer adolescente, o jovem da periferia tenta inserir-se no mundo adulto, conhecendo suas regras, disputando espaço com outros jovens, definindo seu modo de ser e de agir. A cultura atual valoriza padrões de conduta individualistas, onde as pessoas se aproximam de outras por interesses.

A adolescência vivida sob a influência do sistema capitalista de produção está cada vez mais extensa para uns e mais curta para outros. A entrada no mercado de trabalho e/ou a constituição da própria família têm sido o marco para definir a passagem para a vida adulta.

As famílias que possuem renda incentivam seus filhos a estudarem e se prepararem para entrar no mercado de trabalho. Esses jovens estudam, fazem faculdade e começam a viver a vida adulta a partir dos 24 anos, depois de graduados. Eles vivem um longo período sob a tutela dos pais, em uma situação ambígua frente aos adultos que ainda determinam o que devem fazer, mas já tendo condições de tomar suas decisões. Ou seja, as condições históricas, sociais e culturais estão determinando as possibilidades dessa faixa da população viver o período de preparação para a vida adulta.

$\mathrm{O}$ adolescente pobre morador da periferia de uma cidade como São Paulo precisa estudar e trabalhar para ajudar no sustento da família. Esse adolescente, como qualquer outro, procura auto-conhecimento e inserir-se na vida adulta. Pela necessidade financeira, ele entra no mercado de trabalho sem qualificação, e muitas vezes, acaba constituindo família ainda cedo. 
Vive em bairros distantes dos centros produtores dos modelos estampados pela indústria cultural nas vitrines, na televisão e na internet. São esses exemplos, produzidos pela classe favorecida economicamente e divulgados para todas as pessoas, que aprende a gostar e desejar. Por essa visão os jovens pobres são considerados como inferiores, pois não estudaram e não puderam se preparar para conseguir bons empregos. Eles engrossam as filas do desemprego ou do subemprego.

As figuras de identificação, necessárias para o desenvolvimento emocional do adolescente, são apresentadas pela indústria cultural e esvaziadas de sentido quando se imagina uma vida em que nem as condições básicas de existência como moradia, saúde e educação foram plenamente satisfeitas.

As adversidades da vida; o desejo de mercadorias produzidas pela ação humana, mas que fornecem poder a quem as possui; a violência cotidiana que espreita sua existência; a falta de opção por espaços de lazer em sua comunidade; a dificuldade em conseguir um emprego; as utopias coletivas; a insegurança da vida adulta; o trabalho; o estudo; os valores de sua comunidade entre outros, constituem aspectos importantes na construção do desejo do adolescente pobre.

Calil (2003. p. 147) afirma que as crianças e adolescentes filhos das classes pobres interiorizam o significado de perigo que as pessoas atribuem àquele que se apresenta diferente dos padrões propostos pela classe economicamente favorecida e que determina a visão hegemônica de certo e errado. Assim, assumindo o papel de sujeito perigoso, passa a ser o que a sociedade espera dele.

$\mathrm{O}$ ato infracional cometido por adolescentes é um fenômeno mundial. Acontece em países ricos e pobres e em diferentes regimes políticos: EUA, Canadá, França, Colômbia, Moçambique, Inglaterra, Cuba, China. A distribuição desigual da renda e a necessidade da posse de objetos do desejo 
ajudam a compreender a existência de jovens que entram cada vez mais cedo na criminalidade, em situações culturais tão diversas.

Os adolescentes que cometem ato infracional não encontram (e necessitam) intérpretes capazes e dispostos a atinar com o sentido das suas ações. Eles são vítimas de compreensão distorcida e preconceituosa. Eles pedem interpretação para suas ações - interpretação da ação pela voz do agente. A ação deve encontrar alguém, um sujeito e não um criminoso. Nos adolescentes autores de atos infracionais, estes, os atos, impedem a aparência daqueles, os homens.

A juventude da classe média brasileira das décadas de 60 e 70 foi vista como rebelde, com utopias coletivas. Os filhos da classe pobre eram vistos como apáticos. Na década de 80 os jovens pertencentes às classes economicamente favorecidas foram vistos como "rebeldes sem causa". A juventude da classe pobre, a partir da década de 90 passou a circular pela cidade, ao contrário de seus pais. Até hoje são vistos como "perigosos" pela classe dominante e formadora de opinião.

"Às vezes a juventude é vista como produtora de utopias, revolucionária, às vezes é vista como ameaça e risco." (VICENTIN. 2005. p. 246) Sempre que a conduta adolescente é patologizada, ou seja, transformada em problema, perde-se a possibilidade de compreensão de um fenômeno complexo e transformador.

$\mathrm{O}$ ato infracional dos adolescentes, pobres ou ricos, não é um ato coletivo, ele não tem a intenção de mudar o status quo. A revolta é individual, mas a produção do fenômeno é da ordem do coletivo.

Nos próximos capítulos serão apresentadas questões que estão imbricadas na produção do ato infracional, inclusive a não possibilidade de constituir-se como ser autônomo na sociedade que busca a felicidade a qualquer custo por meio da aquisição de objetos. 


\subsection{Perfil dos adolescentes que cumprem medidas socioeducativas no Estado de São Paulo}

A seguir serão apresentados alguns aspectos considerados importantes por essa pesquisa para conhecer o perfil dos adolescentes julgados autores de atos infracionais e inseridos em medidas socioeducativas, atendidos pela Febem - $\mathrm{SP}^{13}$.

A Febem-SP, atual Fundação Casa, em conjunto com o Instituto Uniemp, realizou, em maio de 2006, uma pesquisa sobre o perfil dos adolescentes em medidas de internação, semiliberdade, LA e PSC.

Da população internada (medida socioeducativa restritiva de liberdade), $96 \%$ eram do sexo masculino e 4\%, feminino. A hipótese para esses números é que os adolescentes do sexo masculino praticam mais infrações, essas infrações são mais graves ou, quando as meninas participam de ações graves, não estão na posição de comando.

A maioria dos adolescentes internados (59\%) possuía idade entre 16 e 17 anos. Os jovens entrevistados contaram que começaram a infracionar com 13, 14 anos, mas não foram pegos pela polícia nas primeiras vezes e sim quando mais velhos.

Outra possibilidade para a idade das apreensões estar acima dos 16 anos é que as infrações cometidas por adolescentes de 13 ou 14 anos seriam mais leves, o que levaria o sistema judiciário a dispensá-los.

aí você faz a primeira vez, dá certo, faz a segunda vez, dá certo, aí você não para mais, enquanto você não... não vê aquele objetivo: você morre ou você sobrevive e vai preso, você... (Lucas)

antes de eu ir preso já tinha feito outros assaltos, né, tinha feito outros assaltos e meu primeiro assalto foi no mercado perto de casa... (Alex)

bom, mas isso não aconteceu e acho que isso que me estimulou a... a querer mais, porque eu não fui preso da primeira vez, não fui preso da primeira

\footnotetext{
13 Pesquisa Febem Internos - Maio 2006. Disponível em: <http://www.febem.sp.gov.br/files/pdf/pesquisafebem/pesquisainternos.pdf> Acesso em: 22 nov 2006. e Pesquisa Febem La e Semiliberdade - Maio de 2006. Disponível em <http://www.febem.sp.gov.br/files/pdf/pesquisafebem/pesquisaLA_Semi.pdf> Acesso em: 22 nov 2006.
} 
vez, não fui preso da segunda, e aí no dia... não, eu, ainda... fiz alguns assaltos antes, eu fiz assalto à Lotérica... (Alex)

A escolaridade dos adolescentes quando entraram no sistema socioeducativo estava entre o $5^{\circ}$ e o $8^{\circ}$ anos do Ensino Fundamental. A tabela abaixo indica que eles progrediram nos estudos dentro da Febem, pois aumentou a porcentagem dos graus mais adiantados de escolarização.

Tabela 1- Escolaridade dos adolescentes internos da Febem-SP em 2006

\begin{tabular}{|c|c|c|c|c|}
\hline Escolaridade & Fundamental I & Fundamental II & Médio & Outros \\
\hline Antes da Febem & $14 \%$ & $71 \%$ & $15 \%$ & $1 \%$ \\
\hline $\begin{array}{c}\text { Durante a MSE em } \\
2006\end{array}$ & $9 \%$ & $59 \%$ & $27 \%$ & $5 \%$ \\
\hline \multicolumn{2}{|l}{} \\
\hline
\end{tabular}

Se for feita uma análise entre grau de escolaridade e idade dos adolescentes internos, verifica-se um atraso na escolarização, pois adolescentes com 16 e 17 anos deveriam estar no Ensino Médio.

Dois dos jovens entrevistados contaram que tiveram experiências de inclusão na classe especial, ou seja, ela foi usada para inserir crianças que se apresentavam diferentes do que era esperado, mas que certamente não possuíam nenhum grau de deficiência, pré-requisito para a entrada nesse tipo de classe.

[A sua experiência na escola, B., como foi?] Ah... foi bacana, me colocaram numa sala especial eu sendo normal. [Por que fizeram isso? Um psicólogo sem vergonha fez isso com você?] $E$, vai saber, vai na escola P. M. e pergunta. [Aí você ficou na sala especial?] Isso mesmo. [Muitos anos?] Não sei, o ano que eu estudei lá. (Breno)

[Por que você saiu ?] - da escola

Porque eu era... vamos se dizer assim, eu era a criança problemática, né? Chegava as molecadas, falava coisa pra mim e eu batia neles... é... eu era ignorante, era traste ruim como que dizem os baianos, então o que acontece, daí batia, quebrava vidro da escola é... pichava... é... tinha época de gang também, de pichação, daí o que acontece? Sempre arrumei encrenca dentro de escola e não prestava muita atenção na aula, queria mais namorar, não prestava atenção, fugia de casa às 11 h da manh... da noite pra ir pro salão na sexta-feira com 11 anos de idade e assim foi indo, minha vida sempre foi nessa, nesse... nesse seguido, né? Daí o que acontece? Eu ia pra escola, 
tudo, mas não prestava atenção, daí teve umas... é... umas psicólogas que... esses negócio de escola, daí fez um... psicologia, um negócio comigo, uma consulta comigo, daí falou pra minha mãe que eu precisava de mais atenção, que eu tinha que ficar em sala particular... [Tipo especial, como assim?] Isso, sala especial... [Isso você tinha quantos anos?] Eu tinha uns... 10 anos, uns 10 não, uns 10, 11 anos... [Você sabia ler e escrever nessa época?] Sabia mais ou menos... Daí minha mãe falou "não, vão te colocar numa sala especial, só que é dois meses", só que quando eu fiquei sabendo a real que eu tinha que fazer 2 anos pra completar um ano nessa coisa e eu tinha que ficar com pessoas que era... doentes mentais, que tinha problema de fala, com síndrome... não que eu tenha algum preconceito com isso, que nessa época até namorei com uma menina que tinha problema assim, né? Que não escutava direito... então o que acontece, só que aí eu fui ficando ali, até peguei um pouco de gagueira por causa disso aí... então quando eu fiquei sabendo a real eu não aceitei, falei não, a senhora falou que era dois meses, agora tem que ficar 2 anos pra completar um ano, que não sei que... daí não fui mais pra escola, me mandavam pra escola, tudo, eu ia, mas em vez de eu ir pra Santana, que eu estudava em Santana no T. B., daí eu passava por baixo do ônibus, daí gastava meu dinheiro de condução nos fliperama, no shopping e voltava... como se tivesse ido pra escola, daí ficava aqui no M. e do M. eu ia pra casa... (Douglas)

\section{Lucas falou da falta que sentiu em ter alguém que pudesse conversar} com ele sobre a importância da escola. Nesse caso, a própria escola não conseguiu fazer-se importante em sua vida.

[ você falou que parou de estudar na oitava, né? O que aconteceu aí? Quando você era novinho que você começou... que você falou que entrou no mercadinho do bairro... você estava estudando?] Então, eu tava e não tava entendeu? Escola... tipo que nem eu falei, eu não tive aquela pessoa pra falar "pô, escola é fundamental pra sua vida, pro seu futuro..." entendeu? "Você vai ter prioridade numa escola...." então não, ninguém me falava, então não me via.... (Lucas)

A experiência de Alex foi de bagunçar e ser expulso da escola:

Nossa, a gente bagunçava muito na escola, mas não tinha chegado a época de usar drogas... a gente bagunçava muito e... a gente xingava as professoras e... ia expulso da escola e ia... ia pras ruas e meu... e a gente mexia com todo mundo e ninguém... era uma época boa sim, época boa de bagunceiro mesmo, a gente aproveitava bem a infância e a adolescência... (Alex)

"A criança que não estuda deixa a escola por motivos ligados às condições materiais de sua existência. Quando os jovens podem ir à escola, muitas vezes seu interesse desaparece pela força do desinteresse que a escola 
manifesta por eles. É um impasse de indiferença mútua.” (MELLO. 1999. p. 3)

Em relação a condições de trabalho verifica-se que, no momento da apreensão, 54\% dos adolescentes afirmaram não estar trabalhando. Dos 46\% que afirmaram estar trabalhando, apenas 3\% tinham carteira assinada e 64\% afirmaram ter trabalho regular. Deve-se ter atenção a esses dados, pois não é possível afirmar que a ausência de vínculos formais de trabalho leve o adolescente, ou mesmo o adulto, ao mundo do crime. Mas mostram como as políticas públicas para a inserção no mercado de trabalho são falhas.

É... como eu estava trabalhando de garçom, tinha vez que eu tinha que trabalhar na quarta, na quinta e na sexta e é os dias que mais conta falta, assim, que mais vale e aí eu estudava à noite e pra trabalhar era à noite, aí tipo se fosse pra estudar de manhã não arrumava vaga porque eu era muito mais velho do que todo mundo (risos) aí nunca acaba dando pra conciliar as coisas assim, manja? E... sei lá, é isso. (Breno)

então hoje em dia o que adquiri... só problema pra mim hoje em dia tenho 23 anos, não tenho grau de escolaridade bom, tenho uma passagem na justiça, então o que eu vou adquirir um bom serviço pra mim, um bom serviço que eu vou adquirir ou é de ajudante de pedreiro ou... qualquer outro, agora alguma firma você não arruma nunca mais... nunca mais... então o que acontece? Vou ter que ralar muito mais pra ter uma oportunidade...

(...)

Porque graças a Deus quem tá me dando uma oportunidade é esse rapaz aí

que eu trabalho no baile, certo que é pouco, mas é um dinheiro que ajuda, às vezes eu chego.(...) então hoje em dia eu dou graças a Deus que Deus colocou ele no meu caminho, ele, a tia Elaine, que eu pego parafuso com ela pra fazer também. (Douglas)

E como que, hoje em dia, oitava série praticamente não é nada, eu estou querendo voltar a estudar, mas... porque quando eu trabalhava na $C$ [de office-boy] eu trabalhava numa pizzaria também à noite, então eu saía da C. e ia pra pizzaria, por quê? Porque eu tinha que me manter, aí não tem nem pai, nem mãe, nem família, nem nada, você mesmo tem que se manter, então eu escolheria... ou eu trabalhava pra bancar a casa, entendeu? (Lucas) 
As ocupações exercidas eram, no geral, sem necessidade de especialização ou elevado grau de instrução: ajudante/servente de pedreiro, $16 \%$; lavador de carros, $8 \%$; ajudante geral, 6\%; ambulante, $4 \%$; serviços gerais, $3 \%$. Outras ocupações: reciclagem, panfletagem, ajudante de mecânico, cobrador de lotação, entregador de pizza, funileiro, feirante, balconista, mecânico.

Essas ocupações denotam que o direito à profissionalização dos adolescentes acima dos 14 anos está sendo desrespeitado.

São, no geral, ocupações desqualificadas que tendem a reduzir a criança e o jovem a mão-de-obra barata. Não há respeito ao ser humano em desenvolvimento e muito menos preocupação com a cidadania e a dignidade pessoal. $\mathrm{O}$ trabalho infanto-juvenil parece ser o paradigma da exploração capitalista. Não há qualquer compromisso com o futuro das crianças, pois as ocupações que exercem aproximam-se muito do trabalho forçado, não exigem formação profissional adequada e não solicitam intelectualmente os jovens. (MELLO. 1999. p.4)

Em relação às suas famílias a pesquisa destacou que $51 \%$ dos adolescentes moravam só com a mãe, $23 \%$ com pai e mãe, $7 \%$ só com o pai.

Dois dos jovens entrevistados para essa pesquisa (Alex e Douglas) moravam com a mãe quando cometeram infrações. Alex contou que durante a semana morava na casa do pai porque era mais perto da escola. Douglas contou que perdeu o contato com o pai quando criança. Os outros dois (Lucas e Breno) moravam em instituições desde a primeira infância.

Em relação ao grau de instrução dos pais, $60 \%$ não souberam responder qual a escolaridade do pai e $36 \%$ não sabiam a escolaridade da mãe. Por aqueles que sabiam sobre o grau de instrução de seus pais, nota-se que eles possuíam escolaridade baixa, pois $48 \%$ das mães e $28 \%$ dos pais estudaram até o Fundamental II. Apenas 1\% das mães e 2\% dos pais tinham nível superior.

Os pais também possuíam ocupações mal remuneradas. Estas não exigiam muita escolaridade e necessitavam de pouca ou nenhuma 
especialização. Para os pais, as profissões que apareceram foram: pedreiro, 12\%; caminhoneiro, 4\%; trabalhador rural, 2\%; ajudante geral, $2 \%$; mecânico, comerciante, pintor de residências, também com $2 \%$ cada um. As mães eram: domésticas, 24\%; faxineiras, $10 \%$; cozinheiras, 4\%; costureiras, 3\%; ambulantes, auxiliares de limpeza, promotoras de vendas apareceram com $2 \%$ cada.

Em relação à moradia, $64 \%$ afirmaram morar em uma casa de classe média baixa ou classe pobre. Suas casas ficavam em bairros com coleta de lixo, transporte público, água encanada e com escola e posto de saúde próximos.

No geral moravam em bairros afastados do centro da cidade, com casas muito pequenas que foram construídas pelo governo (as COHABs, CDHUs e Cingapuras) ou em bairros em que os moradores ocuparam a terra e lutaram para conseguir a infra-estrutura básica. Seus pais lutaram por moradia e os jovens não se apropriaram dessa experiência de luta. Daí a extrema dificuldade dos jovens para encontrarem um lugar em um tecido urbano tão desagregador.

O perfil dos adolescentes em meio aberto indicou semelhanças com o perfil dos adolescentes em meio fechado. Chamou a atenção, porém, a porcentagem de meninos e meninas: a maioria continuou sendo do sexo masculino (87\%) . Mas aumentou a proporção de garotas cumprindo medidas em meio aberto (13\%), em relação à proporção em meio fechado.

A escolaridade e as idades eram semelhantes ao perfil da população internada: idades entre 16 e 17 anos e escolaridade no Fundamental II (69\%).

Em relação ao trabalho, $34 \%$ trabalhavam antes da medida socioeducativa e $13 \%$ dos que trabalhavam tinham registro em carteira. As principais ocupações eram: ajudante, 36\%; ajudante de pedreiro, $10 \%$; ajudante geral, 9\%; trabalhos manuais, $18 \%$; entregador, $9 \%$; vendedor, $8 \%$.

Em relação ao bairro em que moravam, assim como na população internada, em geral possuíam coleta de lixo, transporte público, água encanada, escola e posto de saúde perto. 
A auto-classificação sobre moradia indicou uma distribuição em três categorias: casa de classe média (30\%), casa de classe média baixa (33\%) e casa de classe pobre $(29 \%)$.

A escolaridade e as ocupações dos pais apareceram semelhantes ao já citado para o meio fechado.

$\mathrm{Na}$ realidade, a escolaridade e as ocupações de pais e filhos, tanto dos que cumpriam medidas socioeducativas de meio fechado como de meio aberto, apareceram bem semelhantes.

A sociedade de classes produziu o proletário, este indivíduo reduzido ao trabalho desqualificado em quem parece esvanecer-se o rosto humano. A sociedade de classes produziu o proletário para que trabalhasse por todos e em condições aviltantes: conseguiu tornar assustadores aqueles que não pode dispensar. (GONÇALVES FILHO. 1995. pp. 158-159)

Nos anos de 2000 e 2001 o ILANUD $^{14}$ realizou uma pesquisa, no município de São Paulo, com adolescentes acusados de autoria de ato infracional, ou seja, no início do processo judicial, antes de qualquer determinação por medida socioeducativa.

O perfil apresentado por essa pesquisa indicou semelhanças com o perfil de internos ou em cumprimento de medidas de meio aberto exposto anteriormente. Acrescentou ainda que a maior parte dos adolescentes apreendidos residia em bairros pobres e periféricos da capital como Itaquera, Guaianazes, Sapopemba, Santo Amaro e Vila Nova Cachoeirinha.

A Zona Leste da capital apareceu em primeiro lugar como região de origem dos adolescentes $(34,1 \%)$ e a Zona Sul em segundo, com 30,4\%.

Os bairros pobres e periféricos representam o sistema político e econômico vigente e se mantêm pelo mecanismo necessário à reprodução do capital. A experiência de estar em casa, abrigado dos perigos da rua e das

\footnotetext{
14 ALMEIDA, E.M.; HOJDA, A.; KAHN, T.; SPOSATO, K. B. Defesa Técnica de Adolescentes Acusados da Autoria de Atos Infracionais em São Paulo. Revista do Ilanud n. 22. São Paulo. 2002.
} 
humilhações sofridas ao longo do processo de trabalho pode ser satisfeita nas casas inacabadas dos bairros periféricos. A casa dos pobres protege e acolhe.

A comparação histórica e sociológica mostra que, se gueto e subúrbio têm em comum ser, cada um em sua ordem nacional respectiva, zonas de relegação situadas no mais baixo da hierarquia urbana, eles não diferem menos em sua composição social, sua textura institucional, sua função no sistema metropolitano, e sobretudo pelos mecanismos e os princípios de segregação e agregação dos quais eles são o produto. (BOURDIEU. 1999. p. 168)

Os dados apresentados mostraram um panorama da situação dos adolescentes que cometeram ato infracional: baixa escolaridade, moradores das periferias das grandes cidades, não inseridos no mercado de trabalho ou inseridos de forma precária. Esses adolescentes e suas famílias estavam sendo vítimas de processos sociais, políticos e econômicos excludentes.

Fica evidente portanto, que a suspeita ou mesmo a prática de atos infracionais por estes jovens revela muitas vezes, a exclusão social e a marginalização a que são submetidos, impedindo, conseqüentemente a realização plena de seus direitos, antes mesmo do cometimento de uma infração penal. (ALMEIDA; HOJDA, KAHN; SPOSATO. 2002. p. 17)

Todos os jovens entrevistados para essa pesquisa eram moradores de bairros pobres de São Paulo, áreas que expulsam seus moradores para regiões mais nobres da cidade, tanto para trabalharem como para se divertirem. Alex e Lucas moravam na Zona Leste, em bairros tão afastados entre si como o são do centro da cidade. Douglas morava na periferia da zona Norte e Breno morava próximo ao Centro da cidade, bairro que, apesar de estar na região central, é constituído por moradias precárias como cortiços e pensões e habitado por trabalhadores que exercem funções desqualificadas e que recebem baixos salários.

Os jovens pertencem a um espaço geográfico da cidade e identificam-se com ele - basta reparar nas assinaturas de pichações e grafites nos muros da cidade (ZL - Zona Leste; ZN - Zona Norte e assim por diante). 
Você tem que sair dali [da comunidade na periferia], é... ali a gente... pô, tem que mostrar pra ele como que faz pra ele sair dali, senão... se ele ficar nesses pensamentos ele nunca vai sair dali, entendeu? Nunca vai ter um... uma vida fora, nunca vai ter um conhecimento fora, nunca vai poder, tipo, andar de avião, que nem as pessoas lá mesmo onde eu moro, as pessoas falam "ah, pô, queria andar de avião, isso e aquilo". Peguei e falei, meu, você quer andar de avião... é só você correr atrás... é só você correr atrás... (Lucas)

\footnotetext{
O jovem fala de não pertencimento a um espaço e à cidade. Aprende a vida na periferia, pois é ali que ela se dá nua e crua, mas se quiser viver melhor, as "oportunidades estão fora da sua comunidade". Ele está falando da não possibilidade de enraizamento. Para que exista a humanidade no homem, o enraizamento é necessário. Na realidade ele está dizendo de um impedimento de viver.
}

É preciso sair do seu bairro que, estigmatizado pela sociedade, estigmatiza quem nele reside. Para escapar das humilhações que sofre quem assume a posição de submissão e sujeita-se a trabalhos sub-valorizados, é preciso ir para espaços valorizados da cidade e sentir-se pertencente, mesmo que momentânea e ilusoriamente.

O desenraizamento é a posição que o sujeito ocupa de não pertencimento a uma comunidade, da impossibilidade de sentir-se parte de uma cultura própria, de ter uma opinião significativa que será escutada por outros. Os jovens pobres das grandes cidades então inseridos em uma lógica que os torna invisíveis: todos podem ser um ou nenhum ao mesmo tempo. A opinião de um é considerada a de todos, como se não pudessem ser eles mesmos.

“[...] Não ter raízes significa não ter no mundo um lugar reconhecido e garantido pelos outros, ser supérfluo significa não pertencer ao mundo de forma alguma", (ARENDT. 2004. p.528).

A situação do desenraizamento é uma privação dos direitos humanos, pior do que a impossibilidade de liberdade e justiça. Para o sujeito desenraizado qualquer ato seu será julgado da mesma maneira - normalmente de forma pejorativa. "[...] a não ser que cometa um crime, receberá um tratamento independente do que ele faça ou deixe de fazer." (ARENDT. 2004. p. 330).

A seguir, insiro um breve relato sobre a história pessoal dos adolescentes entrevistados. Pobreza e desorganização familiar não são 
responsáveis diretos pelo cometimento de uma infração, como será discutido ao longo desse trabalho, mas fazem parte do engendramento do fenômeno.

A sociedade atual promove para uma parcela significativa da população

a vivência de um processo de exclusão: desenraizamento, desemprego ou trabalhos pouco remunerados, moradias precárias etc.

Então, morei no Bairro do Limão até os 4 anos de idade com a minha mãe, por dificuldades, que a minha mãe bebia muito e eu que tinha que carregar os meus irmãos nas costas e o pessoal, os vizinhos, resolveu chamar o SOS Criança e nisso que o SOS Criança veio e tirou nós, eu e meu irmão da nossa mãe... eu tinha 4 anos, meu irmão tinha 3, e aí tinha eu, meu irmão, minha irmã que tinha 2 e um que tinha 8 meses, acho... Chamaram o SOS Criança porque minha mãe batia demais na gente e ela bebia demais, aí a gente foi parar no SOS Criança, aí eu e meu irmão ficou no SOS Criança, desde os 4 anos até os 9 anos de idade. Depois, nesses 9 anos de idade a gente foi morar com, foi morar com um Padre (...) lá da Pompéia, aí a gente morou um tempo com ele, morou acho que 3 anos com ele (...) Nesses 11 anos de idade, a minha mãe chegou a falecer, aí eu fui morar com a minha família, tudo, aí eles me tiraram de lá e eu fui morar com a minha família lá em N.P.. Morei em N.P. até os 14 anos de idade, aí eu peguei e voltei, nessa que eu voltei, fui morar em São Mateus com a minha vó... (Lucas)

Bom, vim pra cá com um ano e meio, é... meus pais, meu pai, minha mãe estava desempregada quando chegou pra cá, meu pai estava trabalhando. Porque minha mãe trabalhava num hospital lá em Fortaleza, trabalhava já tinha 8 anos, ai ela pediu as contas pra poder vir pra São Paulo, porque achava que a vida aqui seria melhor e meu pai também achava... que aqui... eu teria, é... teria uma vida boa é... sobre cuidado de médico, seria mais fácil o acesso a medicamentos, que em Fortaleza era precária as coisas assim. Bom... acho que... minha infância... [Aí vocês vieram morar onde?] Aqui em São Paulo na região de Itaquera...

(...)

... e quando a minha mãe começou a trabalhar, meu pai falava que ela ia... ela começou a trabalhar e de repente começou a estudar também, né? Pra poder acabar os estudos e... começar uma nova vida aqui em São Paulo... E aí meu pai xingava ela, falava que ela era uma vagabunda... que ela não ia trabalhar, ia ficar com outros caras..., outros homens, traía ele, não sei quê. Isso meu pai bêbado falando. Ele falava isso pra minha mãe e aí minha mãe foi ficando com raiva e acabaram se separando quando eu tinha... 16 anos... (Alex)

Eu tenho 23 anos, nasci dia 31/12/83, morava ali na Vila Constança, Zona Norte.(...) comecei a estudar com 7 anos... (...) eu fui assim criado pela minha mãe, meu pai eu conhecia, só que ele morava longe e eu ia visitar ele de vez em quando, chegou um tempo que eu não visitava mais ele... (...) quando eu nunca mais vi ele eu tinha uns 9 anos de idade [...] minha mãe trabalhava muito como funcionária pública...(...) como você não é criado pelos pais, você sempre tem uma festividade na escola, dia dos pais... como 
eu fazia teatro é... até aqui no Mutirão, na escola, isso aí, sempre tinha aqueles brinquedinhos, aqueles bagulhos pra dar pros pais, tudo, eu pegava e não tinha pra quem dar, via as crianças abraçando tudo ali e você ficava assim mal... que você ficava sentido, porque você não tinha ninguém ali pra você está comemorando junto, a única pessoa era a minha mãe, minha mãe trabalhava muito...

(...)

Eu tenho uma... que é a consideração, né? Que é a filha da minha mulher com outra pessoa e tenho uma que eu nunca vi, é com uma outra menina que é a R., hoje em dia ela deve ter uns 7 anos, 7 ou 8, que eu nunca vi que ela fugiu com a nenê... (...) nunca vi... nem registrei, só sei por causa da família deles, tudo, mas não me falam de paradeiro, não me falam de nada, hoje em dia sei que outro rapaz registrou ela, assumiu a criança e dizem parece que ele é ladrão também, essas coisa e também que se eu fosse lá ele ia me matar, daí eu ia até cobrar, como que eles dizem, cobrar essa fita, eu ia lá, né? Mas deixei quieto, pra lá... foi quando eu comecei a pôr umas coisas na cabeça...

(...)

... meu irmão trabalha muito e de vez em quando chega e bebe, né? Daí já chega, toma banho, deita e dorme pra ir trabalhar no outro dia. Meu outro irmão mais velho só... Deus que guarda ele, né? Que é viciado, é viciado também ele... [Em bebida?] Também, bebida... em... crack, em... cocaína, esses negócio... (Douglas)

eu nasci, pelo menos me disseram aqui em São Paulo, eu sou paulistano, ããããa... estudei até a... oitava série e tô aí... passei muito pela rua... [Morou na rua?] Morei na rua, é... que mais... morei na casa de menor na Djalma Dutra.......\} [Tem irmãos, não?] Devo ter, alguns... minha mãe era prostituta. [Não teve muito contato com ela?] Tive, acho que o suficiente, por isso que ela me deixou. [Tá, aí você foi pra essa casa?] Não, morei na rua depois que eu fui pra casa... [Quando você ficava na rua você ficava onde?] Vários lugares, nunca tem um lugar. (Breno)

De acordo com "As diretrizes das Nações Unidas para a Prevenção da Delinqüência Juvenil" (Diretrizes de Riad) "[...] a prevenção da delinqüência juvenil requer, por parte de toda a sociedade, esforços que garantam um desenvolvimento harmônico dos adolescentes e que respeitem e promovam a sua personalidade a partir da primeira infância" (CURY, GARRIDO \& MARÇURA. 2002. p. 288).

Segundo as caracterizações sócio-econômicas, de moradia, escolaridade e trabalho apresentadas acima, pode-se afirmar que as famílias dos adolescentes que cometeram ato infracional viviam, no momento da infração, um processo de exclusão social, econômica e política. Estavam privados de renda, direitos, esperança. 
"Embora a população brasileira esteja mais educada e possua domicílios com mais infra-estrutura, é ainda muito pobre, conformando um amplo segmento que é obrigado a residir em favelas, loteamentos periféricos ou terras agrícolas improdutivas." (SALES. 2004. p.69)

Para as crianças e jovens das periferias faltam oportunidades de receberem uma boa educação, apesar da maioria do povo brasileiro ter, atualmente, acesso à escola; ou de receberem boa saúde, apesar de, como vimos anteriormente, os adolescentes residirem em bairros que possuem postos de saúde; possuírem oportunidade no mercado formal de trabalho, ou de morar em uma casa própria etc...

Os jovens que moram na periferia das grandes cidades sofrem com as pressões da indústria cultural, com a falta de trabalho que proporcione aprendizagem e crescimento, com a qualidade da educação que recebem. Eles não têm dinheiro para consumir, sentem-se desvalorizados, humilhados. Grande parte deles se conforma - daí o pequeno número dos que optam por cometer infrações. Alguns reagem com violência à violência sofrida - a revolta pode proporcionar o autoritarismo. Outros tentam entender e criticar a situação - a revolta também pode proporcionar a crítica e o pensar por contradição.

A proposta da sociedade brasileira para diminuição do número de adolescentes que cometem atos infracionais tem sido individual, responsabilizando unicamente os jovens.

Esse discurso é tão contundente que impregna nas pessoas. No capítulo sobre a mídia será possível verificar como a imprensa auxilia na compreensão do problema como uma questão individual.

Veja a fala de um dos jovens que encara o problema individualmente. A ideologia dominante faz crer que o problema é seu! É ele que precisa ser forte para não aceitar convites para trabalhar no tráfico de drogas, é ele que precisa trabalhar para poder sair da periferia. 
caminho bate na porta da sua casa, esse caminho bate, todo dia, todo dia bate, então... pra você ser forte é difícil, é difícil... (Lucas)

Esse adolescente não tem consciência que o tráfico de drogas mobiliza milhões de dólares mundialmente ou que as casas populares são afastadas do centro para que os 'pobres' fiquem longe o suficiente para não serem vistos pelos 'ricos'.

O tráfico de drogas é uma atividade econômica que deve ser entendida no contexto da sociedade de consumo. Seu universo está dentro da lógica perversa do capital e das relações de trabalho aviltantes. Ele estimula a circulação legal e ilegal de dinheiro e armas, movimenta milhares de reais por ano. Além de definir a circulação de dinheiro, define também a circulação de pessoas.

“[...] O tráfico de drogas, do mesmo modo que outros mercados ilegais, aparece como resposta à marginalidade econômica de países, regiões ou parcelas da população, vítimas do crescimento econômico desigual e da desilusão social, e das constelações de tensões, conflitos e antagonismos." (FEFFERMANN. 2006. p. 35)

A lógica perversa do capital está presente no mundo do crime, com a diferença que nesse, as regras são claras, a dominação é explícita e a punição não é o desemprego ou a humilhação, mas a perda da vida. Até para servir de exemplo para outros...

Feffermann (2006) relata estas características para o tráfico de drogas, mas pelas falas dos jovens entrevistados as mesmas estão presentes quando se trata de outros crimes:

Pode-se imaginar que se criam elos de gratidão que, na realidade, transformam-se em elos de subserviência, de sujeição. A ajuda exige uma contrapartida. A solidariedade tem um preço, que é o silêncio e a convivência com o que se vive. O silêncio reforça o discurso do medo. É o discurso do capitalista: a empresa assegura algumas regalias ao funcionário - vale-refeição, vale-transporte, paga a escola do filho do funcionário, cria a perspectiva de ascensão, mas aprisiona o funcionário. (FEFFERMANN. 2006. p. 278) 
A redução da maioridade penal é uma proposta que corrobora a convicção de que as razões para se entrar no mundo do crime são individuais. Essa proposta conta com o apoio de setores conservadores da sociedade, que lucram com a venda de armas, equipamentos e serviços de segurança particular. Para obterem lucros precisam disseminar o sentimento de insegurança social e de impunidade.

Faz-se necessário uma crítica sobre os mecanismos que a sociedade mantém para deixar à margem uma enorme parcela de adolescentes e jovens: a pseudo-educação oferecida, poucos espaços de cultura e lazer, pouca ou nenhuma oportunidade de efetiva participação em grupos em que a palavra e a ação de homens livres possam proporcionar a humanização das pessoas. É necessário buscar as brechas existentes para superação das contradições presentes na sociedade capitalista. 
Capítulo 5 - OS JOVENS ENTREVISTADOS O RECORTE DA VIOLÊNCIA AO LONGO DE SUAS VIDAS 


\title{
5. OS JOVENS ENTREVISTADOS - O RECORTE DA VIOLÊNCIA AO LONGO DE SUAS VIDAS
}

\begin{abstract}
A violência é, pois, manifestação do poder, expressão de como as relações sociais estão aqui organizadas, de como o capitalismo se engendrou e se perpetua no país. É exploração, opressão e dominação, mas não é somente força pura, é também ideologia e sutileza. Violência que embora seja estruturalmente produzida pelas elites, como um dos mecanismos que sustentam e fazem a política e a economia, não constitui seu patrimônio exclusivo. Reproduzida pelos mais diversos extratos sociais, tende, porém, a ser associada de maneira reducionista e invertida, pelo senso comum aos mais pobres e miseráveis, vistos como "classes perigosas" e de onde provêm os "maus elementos". (SALES. 2004. p. 48)
\end{abstract}

Algumas condições devem ser levadas em consideração para se pensar a violência que pode sofrer um indivíduo.

Para a psicanálise, a violência é fundadora da civilização e determinante na subjetividade dos indivíduos. "[...] é assumindo a violência fundamental que se permite a relação com o outro de forma criativa e não fusionada [...] É a condição do aparecimento do sujeito." (MARIN. 2002. p. 142). Se a violência fundamental não for assumida, o sujeito fica exposto a uma sensação de desamparo intensa, o que pode levá-lo a querer destruir o outro como forma de manter sua singularidade. (MARIN. 2002. p.165).

Em outro momento, Marin afirma que em "[...] uma sociedade que não garante um lugar para seus indivíduos, que produz e reproduz situações de exclusão das mais diferentes ordens - de classe socioeconômica, de gênero, de raça etc - , está ativando uma violência aniquiladora.” ( 2002. p.78).

“[...] Se a derivação para a violência e para o crime configura-se como uma espécie de opção, escolha ou vontade de alguns, [...] é justamente porque, em algum momento, as leis deixaram de ser aplicadas." (PERES, CARDIA, SANTOS. 2006. p.31). Essas podem ser as leis da sociedade ou a lei da interdição pela cultura, que garante a constituição de um indivíduo. 
A unidade familiar, ou quem exerce esse papel, tem importância fundamental no desenvolvimento emocional saudável de uma pessoa.

Para que o indivíduo se desenvolva de forma saudável, é importante garantir certa constância e previsibilidade no ambiente e no cuidador. Um ambiente caótico significa que a área central da personalidade da pessoa em formação deve ser protegida para evitar danos. Essa proteção impede o desenvolvimento emocional satisfatório.

Todas as crianças precisam crescer em um ambiente que suporte sua agressividade, que a nomeie, transforme e dê lugar a ela na constituição de uma existência saudável. A agressividade faz parte da constituição do ser humano. $\mathrm{O}$ adulto que cuida precisa interagir de forma a permitir ao outro agir com autonomia, garantindo regras de convivência que auxiliem na constituição de um indivíduo que reconhece no outro um ser diferente dele mesmo.

“[...] o que as crianças precisam é de estabilidade ambiental, cuidados individuais e continuidade desses cuidados." (WINNICOTT. 2005. p. 82)

Quando essa relação de cuidado de um indivíduo adulto com uma criança não foi possível de ser estabelecida - ou por afastamento da criança ou por falta de condições emocionais daquele que cuida - a criança sofre em não conseguir nomear suas emoções, irrita-se, desconfia, destrói aqueles que se aproximam dela, impõe a necessidade de ser limitada, contida em sua agressividade.

Quando as instituições básicas responsáveis pela socialização do indivíduo falham - a família, a escola, a comunidade - a polícia, como representante da sociedade para garantir a ordem, exerce o poder de impor limite àquele que desesperadamente busca-o externamente, pela impossibilidade de construí-lo internamente.

Os adolescentes que cometem atos infracionais buscam na sociedade um limite que não foi possível ser internalizado, ou por falha no ambiente, ou 
porque, quando crianças, não puderam sentir a presença segura de adultos protetores e responsáveis por eles.

Para reconstruir esse laço primário saudável que não foi possível de se estabelecer é necessário um ambiente acolhedor, em que a criança ou o adolescente possam sentir confiança. Um ambiente com pessoas que agüentem sua agressividade, para que ela seja contida e transformada em algo produtivo cultural e socialmente.

"É tarefa do adulto impedir que essa agressão fuja ao controle, proporcionando uma autoridade confiante dentro de cujos limites um certo grau de maldade pode ser dramatizado e usufruído sem perigo. A retirada gradual dessa autoridade é uma parte importante do lidar com adolescentes [...]" (WINNICOTT. 2005. p. 101)

$\mathrm{O}$ adolescente que rouba um objeto de alguém pode estar tentando desesperadamente buscar apoio. Ele está expressando um protesto pela privação vivida ou sentida durante a primeira infância. Seu ato demonstra sua raiva pelo sentimento de privação, vivido depois de um período de bons cuidados. Demonstra também o desejo por estabelecer uma relação saudável que se perdeu em alguma fase da sua vida infantil. $O$ jovem acredita que o mundo externo, que o privou um dia e destruiu suas defesas internas, deve ser responsabilizado e sofrer, assim como ele, conseqüências dolorosas.

Nos mais simples termos possíveis, a tendência anti-social é uma tentativa de estabelecer uma reivindicação [...] No comportamento anti-social patológico, o jovem anti-social é impelido a corrigir, e a fazer com que a família ou a sociedade corrija a omissão que foi esquecida. O comportamento anti-social pertence a um momento de esperança numa criança que está, sob outros aspectos, sem esperança. No ponto de origem da tendência anti-social está uma privação, e o comportamento anti-social visa corrigir o efeito da privação, negando-a. (WINNICOTT. 2005. p. 295)

Quando trabalhei no SOS Criança, conheci a história de Pezinho, um garoto que morava nas ruas. Vivia sozinho, não seguia um grupo fixo de amigos. Sempre se virava para conseguir comida, roupas, banho e abrigo. De tempos em tempos ele se deixava apreender pelos policiais, cometia pequenos 
furtos para ser encaminhado para a Febem. Nessas ocasiões ele dizia que estava com saudade da 'xepa'15. Pezinho buscava o cuidado dos funcionários da instituição que, de uma forma talvez precária, mantinha-o seguro das possibilidades e perigos que a rua oferecia para ele.

Aquela criança pedia limites quando não suportava mais estar sozinho com sua agressividade.

Neste capítulo foi realizado um recorte na fala de cada um dos entrevistados para perceber as violências sofridas ao longo de suas vidas.

Foram situações que aparentemente podiam não ter um caráter violento ou bruto, mas que produziram humilhações e sofrimentos. Aquela violência não nomeada que torna o sujeito impotente frente à possibilidade de enfrentála. Entre essas violências, destaco a necessidade de trabalhar cedo para ajudar a sustentar a família, as experiências mal sucedidas na escola, a criminalidade que espreita a formação do jovem, as relações familiares desgastadas pelo abandono dos pais ou pela necessidade deles trabalharem e se ausentarem de casa e dos filhos, a falta de diálogo etc.

Também a violência da homogeneização de corpos e mentes, a patologização do diferente, do "vagabundo", do lento, mas também do rápido, do apático e do falante etc.

Este capítulo ajudou a compor a história, o contexto sócio-econômico, cultural e emocional em que viveram esses adolescentes e tantos outros que não participaram ativamente desta pesquisa, mas que vivem em condições semelhantes.

Nas entrevistas dos jovens foi possível perceber a socialização dos adolescentes no contexto da violência. A violência é uma produção humana e implica em efeitos tanto na esfera pública como na privada.

As violências presentes na vida de todos compõem uma história de violência que acompanha a vida das classes populares no Brasil.

“A disseminação da violência está articulada com o fracasso dos mecanismos sociais de regulação da vida coletiva.” (TRASSI. 2006. p. 207)

\footnotetext{
${ }^{15}$ Xepa é a comida servida na Febem.
} 
A revolta adolescente faz uso da violência por ser esta bastante conhecida em suas vidas - eles a sofrem cotidianamente. A violência legitimada pelas forças do Estado para manter a ordem passa a ser usada e vista como legítima por aqueles que querem transformar e eliminar a violência de suas vidas.

A revolta que usa de violência briga para não sofrer humilhações. A revolta exige que a passividade e a servidão se movimentem.

A história pessoal singulariza o sujeito e dá voz ao agente da ação: aquele que foi visto unicamente pelo recorte da prática infracional e agente da violência, agora é visto e apresentado como aquele que sofreu diversas formas de discriminação, humilhação e maus-tratos, aquele que sofreu experiências violentas e injustas produzidas pelas instituições responsáveis por representar a lei - a família, o sistema judiciário, a polícia.

Nesse momento, estando inteiros com suas histórias, esses jovens podem ser vistos e ouvidos de uma outra maneira. Produzem emoção no leitor, podem ser entendidos, criticados por seus atos, discriminados ou recriminados. Foram aqui apresentados como seres humanos que partilham uma história comum com o resto da humanidade e que ajudam a construir essa história.

Os destaques que virão a seguir não devem servir para justificar a prática infracional desses jovens. A violência vivida por eles deve ser levada em consideração ao serem analisadas suas experiências infracionais.

“[...] Na verdade, a violência está mais relacionada com a desigualdade social e sua expressão jurídica, que é a desigualdade de direitos; acredito que a desigualdade de direitos afeta mais diretamente a questão da violência." (ADORNO. 2000. p. 132) 


\subsection{Alex - a guerra na cidade grande}

\section{A expulsão da família da terra natal - a violência do desenraizamento}

... Então, eu nasci em Fortaleza dia 21 de novembro de 1983, vim pra São Paulo eu tinha mais ou menos um ano e meio, minha família toda, tenho dois irmãos, um irmão e uma irmã [...] minha mãe trabalhava num hospital lá em Fortaleza, trabalhava já tinha 8 anos, aí ela pediu as contas pra poder vir pra São Paulo, porque achava que a vida aqui seria melhor e meu pai também achava... que aqui... eu teria, é... teria uma vida boa é... sobre cuidado de médico, seria mais fácil o acesso a medicamentos, que em Fortaleza era precária as coisas assim.

\section{O alcoolismo, as brigas e a separação dos pais - a violência doméstica}

... Aos 15 anos meus pais se separaram, antes meus pais já queriam se separar quando eu era mais novo, mas eles esperaram eu crescer mais um pouco pra... [...] Mas um dia eu descobri porque que era os motivos... os motivos era porque o meu pai batia muito na minha mãe, bebia demais e brigava muito... e quando a minha mãe começou a trabalhar, meu pai falava que ela ia... ela começou a trabalhar e de repente começou a estudar também, né? Pra poder acabar os estudos e... começar uma nova vida aqui em São Paulo... E aí meu pai xingava ela, falava que ela era uma vagabunda... que ela não ia trabalhar, ia ficar com outros caras..., outros homens, traía ele, não sei quê. Isso meu pai bêbado falando.

\section{O grupo perigoso que amedronta a comunidade e impõe respeito pelo medo - a violência contra eles mesmos e contra os outros - A valorização da imagem}

A gente jogava uma bola, mas a gente era o grupo que os... que o pessoal da nossa idade tinha mais medo... e a gente jogava bola, e o pessoal jogava bola com medo da gente, assim... e isso era estranho, era estranho e ao mesmo tempo... é... nós se sentíamos bem de tá, tá meio que dominando o espaço assim...

[Isso vocês sentiam como legal?] Isso a gente se sentia bem com isso, porque... era uma forma de criar um certo respeito..., criar um certo respeito no meio da... da comunidade, no meio da malandragem, a gente tinha um certo respeito, porque a gente já, desde pequeno, desde os 15 anos a gente já tava começando a roubar, assaltar e... a gente fez isso sozinhos, sozinhos que eu digo, não precisou de ninguém que já estava no meio do crime pra gente poder começar a assaltar.

\section{A necessidade de trabalho precoce}

eu acho que todos tinham... o mesmo... a mesma cabeça... de que... por mais que a nossa família tivesse assim... passando uma necessidade, a gente já 
tava com a cabeça assim... que a gente tinha que ser homem, homem é... pra poder já sustentar a família, mas não querer trabalhar, porque na época era só diversão, né...

\section{A marginalidade presente na periferia espreita a formação do adolescente pobre}

essa idéia, mas eu acho que foi isso, de alguma forma essa idéia veio de outra pessoa, de outra pessoa fora do grupo, que deu a idéia pra gente de combinar tudo certinho antes de... de chegar pro assalto.

$$
\text { [...] }
$$

nisso a gente já tá em outro tempo, começamos a conviver com outras pessoas que assaltavam também, mas a gente sempre assaltava o mesmo grupo, como parceiros, amigos de escola viraram parceiros, que já não ia pra escola, já não queria mais saber de nada só queria saber de dinheiro, de assalto... de viver no meio da malandragem e de sentir que as pessoas tinham medo, algumas pessoas tinham medo da gente.

\section{A violência do silêncio - a falta de diálogo na família}

Pra ser sincero... eu... eu fui... porque... eu vi aquela revolta dos meus pais e assim, de uma certa maneira quando eles se separaram, meu pai não ganhava tanto pra, pra sustentar e aí começou a atrasar algumas coisas e aí eu queria ajudar de alguma forma, mas eu não conseguia trabalho, né? Eu não sabia por onde procurar um trabalho, não tinha um conhecimento... não tinha alguém que chegasse pra mim "oh, é... tem um trabalho aqui, vai lá, procura, e aí tinha uns meios mais fáceis, assim, que eu já conhecia, eu acho que é por isso...

\section{O uso da força na palavra e nos gestos - a violência nos assaltos}

... e eu dei voz de assalto, e eu que estava com essa arma de brinquedo, acho que foi a primeira vez que eu cheguei e dei voz de assalto, porque da outra vez era aquele grupo e o grupo só chegou, mostrou a arma, pegou e foi embora, agora não, agora a gente já estava meio especializado em dar voz de assalto, pra pessoa já se sentir intimidada e a gente já pegar o dinheiro que estava com ela, e ela estava com o dinheiro no envelope, uma parte no envelope e outra parte no bolso. E aí chegamos os três, eu agarrei essa vítima que era um homem, que eu não lembro se ele estava de óculos ou não, mas era... era um homem, eu agarrei ela pelo pescoço e pus o... a arma na cabeça dela e falei que era um assalto que a gente queria só o dinheiro, se ela quisesse ir embora ia ter que dar o dinheiro.

$$
\text { [...] }
$$

... a gente acabou tomando o revólver dele e assaltando a lotérica, a gente mandou todo mundo pro chão, tinha umas pessoas muito com medo, já chorando, gritando, a gente pediu pra elas ficarem quietas, mas mesmo assim a reação das pessoas era... era extremamente amen..., amedrontosas enquanto a gente tava fazendo uma coisa assim... que pra nós já tinha virado diversão, já era como roubar doce de criança, mesmo que ela grite, você pega o doce e sai correndo (risos) e não liga pra ela, assim...

$$
\text { [...] }
$$


... e aí eu meti... eu coloquei a arma sobre a cabeça da... do cara, que era... como a gente falava era... eu meti a peça na cabeça do Beco e... dei a voz de assalto... [...] eu lembro e aí eu... eu não tinha nenhuma bala dentro do revólver, não, minto, eu tinha uma bala dentro do revólver e aí eu jog... dei um soco na vítima, peguei ela e joguei assim ela... [...] joguei a vítima de uma tal maneira que ela estava... ela caiu no chão, era um... um moleque da idade que eu tô agora...

$$
\text { [...] }
$$

o tiozão não queria dar, não queria dar de nenhuma maneira... e tava dentro do bolso, ela tinha colocado em dois bolsos, pôs um tanto num bolso e o outro no outro bolso. Só que quando ela chegou no bar ela entrou dentro do banheiro direto... a gente tomou uma coca-cola esperando ele sair, quando ele saiu ele tomou, pediu uma cerveja, quando ele pediu uma cerveja pro dono do bar, a gente deu voz de assalto e aí o dono do bar é... deitou no chão e tinha mais duas pessoas no bar também que ficou assustada e... colocou a mão na cabeça e... não lembro se só... só levantou as mãos, mas a vítima falou que não ia dar o dinheiro... e aí o que que eu fiz, na revolta de que ela não dava o dinheiro, e meu, meu parceiro entre aspas, que... que tava ali comigo, que pegou... que queria também o dinheiro que tava na... tava na fita, na missão, né? Como a gente dizia... que tava no lugar comigo, ele não conseguia encontrar o dinheiro... só que ele tinha entrado dentro do banheiro, a vítima, e eu acho que colocou no... colocou por dentro da calça, né? Por dentro da cueca dele e aí ele procurando no bolso ele não conseguia, aí o cara falou que não tava com dinheiro, que não tava com dinheiro, nisso eu já... nessa hora eu me injuriei e o meu parceiro também, eu dei um soco na barriga do car., da vítima, eu dei duas coronhadas na cabeça e uma no nariz, nisso começou a escorrer sangue, começou a sangrar e o cara caiu no chão, na hora que o cara caiu no chão, aí ele pois... é... bateu assim no saco do cara, o meu parceiro botou assim a mão por dentro da calça e pegou o, pegou o dinheiro, pegou um... um bolo de dinheiro - assim mais ou menos, dessa altura assim [fazia o gesto] - tinha 50, 100 reais embolado num elástico, aí o cara tava com 50 reais só no bolso de trás, que era, eu acho que pra pagar a cerveja... pra trocar esse dinheiro...

\section{A ética na malandragem - a violência dentro do mundo do crime}

... que menor a gente achava que... a gente achava não... o menor ficava bem pouco tempo que o de maior, e o de maior perdia a vida enquanto era preso a primeira vez, perdia a vida não, em assim, não conseguia mais um trabalho... não conseguia mais nada, e menor não, menor era sempre aquele cara que segurava todos os $B O$ de... do grupo todo, se tivesse o grupo só de maior, o menor ia levar a peça, pegar o dinheiro, fazia tudo enquanto o de maior só escalava ou só chegava junto, dava um soco ou apavorava a vítima, pegava o dinheiro, mas o menor, se fosse preso os 4 e tivesse só um maior, tipo assim, três maior de idade e um menor, o menor era o que segurava o refrão, segurava o $B O$ dos 4 e falava que ele estava com a peça, que não conhecia esses caras, ou conhecia mesmo, tava na rua, não sei que... inventava qualquer história pra que não fosse preso os de maior, porque se você levasse, se você caguetasse, que era... cagüetar na gíria é... é você dedurar outra pessoa, né? Então... o de menor tinha sempre que ter uma história pra que os de maior não fosse preso junto com ele... é... porque senão se caguetasse é... chegasse na Febem ou em... ou não voltava mais 
pra casa, ia ser morto quando voltasse pra casa se não fosse morto na própria Febem... [Ia ser morto por quem, se voltasse pra casa? Pelo próprio grupo?] Pelo próprio grupo porque caguetou e levou os outros preso ou senão perdia o respeito no crime e nunca mais assaltava... nunca mais assaltava e nunca mais ia ter a convivência com essas outras pessoas, né? [...] E aí... você não tinha... não tinha respeito na quebrada, não tinha respeito aonde morasse.

$$
\text { [...] }
$$

...uma amizade, uma amizade super sincera assim, mas sincera até o ponto que você não, que você não deixe falha nenhuma com nenhum... é... não deixe nenhuma falha, nem um pé sequer... nenhum... rastro, assim... você vai ser bem conceituado, bem considerado e vai ter uma amizade sincera, mas se não acontece isso, você é traído de a ponte de... as próprias... o próprio convívio que as próprias pessoas chegarem a matar você.......] A lei é você nunca falhar no crime... é, quer dizer, nunca falhar com o seu... por exemplo, se você vai num assalto e cagueta, já é uma falha, se você vai num assalto e vai preso e o pessoal que tá na rua não ajudar a sua família, não... não seguir à risca com você... não chegar junto com você, que é o que diz, né? Você também já tá deixando falha no crime e aí você não é conceituado, não é bem visto, né? E aí isso vai acumulando na... na mente das pessoas e quando você dá... chega um ponto que você dá uma falha, os caras já falam todas as falhas anteriormente que você já deu e aí acrescenta mais essa e aí você acaba morrendo ou... sendo espancado, ou... sei lá...

$$
\text { [...] }
$$

os próprios colegas que estavam comigo foram lá e falaram pra minha mãe: "ó, o Alex foi preso, ele está em tal delegacia”, porque eles já são... já sabiam, né? (...) aí esse dinheiro que a gente pegou, eles deram tudo pra minha mãe, não, minto, não deram tudo, deram... 900 reais pra minha mãe, pra minha mãe se manter um pouco e... e ir lá me ver, me visitar, porque logo logo eu estaria na rua..

\section{As duas faces da mesma moeda - a violência dos e contra os policiais}

... eu acho que eu já estava com tanto... ódio assim de, de não ser preso... de, ódio de policial porque também na... nas ruas aonde que a gente ficava, a gente sempre era o mesmo grupo e aí... eles tinha meio que medo assim, porque quando a gente era... era abordado por eles, eles batiam e diziam que uma hora ou outra eles iam pegar e iam matar a gente.. [...], mas ao mesmo tempo eu fiquei com medo, fiquei com medo, de repente eu atirar e matar os policiais e... de repente ser preso por homicídio, uma coisa assim.

\section{Os acordos possíveis - a violência da corrupção}

...chamava eles de mão branca porque eles eram... eles já eram policiais disfarçados é... vestidos normal e vocês não... nem se ligavam que eram policiais [...] porque que a gente chamava eles de mão branca, porque eles tinham... com eles tinham um acerto, assim tinha um acerto de você dar um dinheiro e você não ir preso e nessa vez que eu fui preso eu tentei ainda fazer acerto com os policiais... 


\section{Os castigos físicos - a violência da tortura}

...bom aí eles me levaram pra viatura e me fizeram... me bateram bastante até eu falar quem tava comigo. [...] Bom, nesse dia eu apanhei bastante que era pra eu levar os policiais até minha casa, que era pra cagüetar as pessoas que estavam junto comigo, mas eu resisti a..., a toda a... a toda essa pressão de apanhar, de me baterem, torturar, de uma certa maneira e não levei ninguém preso junto comigo, assim, mas tinham pessoas que estavam junto comigo.

... apanhei de novo, mas tomei muito tapa na cara, muito, muito mesmo, que era de mão aberta assim e tinha um policial que, que falava assim pra mim que... que quando eu saísse, que ele ia me matar porque... eu era um ladrão pé de chinelo, que não precisava eu ter batido tanto na vítima, e a vítima foi parar no hospital também.

\section{A rebelião - a violência dos e contra os funcionários e policiais}

...acho que o momento mais crítico assim na Febem... nessa época, teve outros né, de apanhar... de não sei que, mas teve uma rebelião que a gente quebrou tudo e a Choque entrou, a gente teve que entrar pra dentro dos barracos antes que ela... que a Choque começasse a jogar gás, gás lacrimogêneo e começar a bater, só que nisso os barraco, os barracos ficaram aberto e a gente de coruja e ficaram cada guard... um guarda... dois guardas da Choque em cada barraco, assim... eram... 6 barracos, cabiam 12, 12 menores em cada barraco que eram 6 por 12... que dava 68... né? [...] e nesse dia a gente tomou uma ducha que era de, que era de mangueira de extintores, sabe? De bombeiro, água gelada, meu! E a corrente da água muito forte, nossa! Minhas costas ficou toda vermelha porque a gente agachou, ficou de... é... a gente ficou de... de... como é que é? Assim, e com a mão na cabeça... [...] Ficou de cócoras, canguru, é cócoras, com a mão sobre a cabeça assim ó [gesto] por baixo do joelho assim e... a gente ficou por três horas mais ou menos, não podia se mexer... se mexesse, a gente tomava... banho... a gente já tinha tomado esse banho gelado de... essa mangueira e não estava calor, estava frio...

$$
\text { [...] }
$$

na rebelião os caras pegaram esse cara.. que ele era... ele era estrupador e... tava no seguro e quando virou a casa, que era a rebelião, né, quando o motim aconteceu, ai os caras pegaram ele, colocaram em cima de um colchão assim ó e pegaram, a gente chamava de Highlander, que era umas naifas, que eram uns, umas barras de ferro, que a gente apontava no chão mesmo e aí virava uma lança, com a ponta de lança e atravessou no coração do cara de uma tal maneira... que aí eles fizeram... meio que uma churrasqueira com carne do cara, que botaram de atravessado ele, ele assim é... na Highlander, na... nessa barra de ferro, colocaram entre as grades... uma grade e outra grade de um portão aberto assim, era um portão aberto e um fechado, colocaram entre ele, colocaram o colchão embaixo, tacaram fogo nele, deixaram ele queimar e aí arrancaram o pescoço, arrancaram o pescoço dele com... acho que era um... um... facão bem afiado, só que era também de barra de ferro, só que era aquela barra de ferro mais... mais fina e aí afiava, né, e arrancaram o pescoço dele assim e 
ele ficou com a cabeça assim e jorrando sangue, já tava morto... já tava morto e aí ele começou a queimar, queimar e aí depois é... pegaram o corpo dele e queimaram e jogaram pra Choque, e jogaram pros funcionários lá, nisso tinha um monte de refém lá que era os funcionários e tinha os Seguro que era refém também nosso... bom, mas isso foi só... algum, algumas coisas que ficaram assim na cabeça, é marcado, gravado que assim é... não... é inesquecível, mas tem outras coisas também que eu passei muito, que eram também piores...

\section{A violência da discriminação}

Mas eu terminei o terceiro, ó... eu passei no chute na sétima, passei no chute na oitava, passei no chute no primeiro, estudei na Febem, estudei na Febem, tinha escola lá, tinha uns cursos profissionalizantes, mas o... o certificado que davam era... por exemplo é... certificamos que A. é... teve... concluiu o curso no Complexo Franco da Rocha, sabe assim? Como cê vai apresentar uma coisa que... porque é um passado, assim, não é inesquecível, mas é um passado, assim, que você, que pra algumas, algumas pessoas, que pra alguns lugares você não tem que dizer e... falar que você passou pela Febem, não sei o quê...

$$
\text { [...] }
$$

Então, mas é isso, mas a convivência com a minha mãe está super bem, super boa, assim, ela está super feliz, super feliz, ela fala de mim, assim, pra qualquer pessoa com muito orgulho de..., mas ela não fala que eu já passei pela Febem, essas coisas, mas ela fala com muito orgulho que.. que é eu que cuido dela porque meus irmão estão casados...

\section{A dor materna - a violência de ver um filho preso}

depois da delegacia, que minha mãe já tinha ido lá, ela... chorou bastante e ela teve um AVC, que é o derrame... que é o derrame na... bom, aí ela... nesse dia ela teve um AVC foi direto pro hospital, não lembro qual hospital que ela foi, mas ela foi pra algum hospital lá próximo...

$$
\text { [...] }
$$

ela ficou internada 2 vezes, na primeira vez e na segunda vez ela ficou internada no Hospital do Câncer, é... com o mesmo problema que era de AVC... minha mãe teve dois AVCs e no decorrer da minha... da minha tirada de cadeia que era... no meu tempo na Febem ela teve AVC, teve também por causa da rebelião que mostrava o negócio, tal e aí ela teve esse AVC de novo... 


\subsection{Breno - o corpo sem forma, a perda do passado}

\section{A passagem pela rua}

passei muito pela rua... [Morou na rua?] Morei na rua, é... que mais... morei na casa de menor na Djalma Dutra...

$$
\text { [...] }
$$

presenciei nos meus olhos a invasão do Carandiru quando eu era moleque, morava lá na Luz, não lembro nem a data, mas presenciei os caras entrando, cordão de gente, de família lá na frente, tomei um tapão no meio da cabeça... [De quem?] Dos... da cavalaria... e é isso, lembro como se fosse hoje... hum, mas continua.

\section{A família - a violência na ausência}

[Tem irmãos, não?] Devo ter, alguns... minha mãe era prostituta. [Não teve muito contato com ela?] Tive, acho que o suficiente, por isso que ela me deixou.

\section{[...]}

É... eu sempre fui excluído da escola... aí teve essa parada, aí tipo reunião de pais, não tinha pai, sabe essas coisas que vai te deixando meio mal assim? Mas assim eu fui devagar e sempre e tô aí.

\section{O fracasso da escola}

[A sua experiência na escola, B., como foi?] Ah... foi bacana, me colocaram numa sala especial eu sendo normal. (...) [ Muitos anos?] Não sei, o ano que eu estudei lá.

\section{A violência da sobrevivência - a fome, a moradia}

E eu aprendi que o negócio é, mesmo que você peça, oh por favor me dá? Que nem hoje, eu estava, tipo ó eu tô com... 7 mangos, tá ligado? Aí eu tava, só que de manhã eu estava só com 4, aí peguei o metrô sobrou 2, tá ligado? Depois tomei um açaí porque... é como se fosse um prato de comida, né? Aí ainda tinha 10 reais, troquei, agora estou com 7 reais e... tipo... só vivendo, sabe assim? Só devagar e sempre na pegada.

$$
\text { [...] }
$$

acho que eu vou, deixa melhorar agora, eu pagar o aluguel que inclusive não paguei todo o aluguel, preciso arrumar uma grana, por isso que eu vim aqui falar: meu, por favor, entendeu assim?

\section{A violência da palavra na ausência dela}

Acho que você tem que viver pra você aprender, não adianta ficar só perguntando, né? Eu perguntei muito e teve pessoas que ficaram quietas, por isso que eu tô... meu, eu tô aprendendo que tem que ficar quieto, só isso, ficar quieto... Continua, desculpa... [...] Então, mas eu acabei de te falar que é melhor ficar quieto do que contar, entendeu? Então o quê? Você que é a psicóloga, não é assim? Os psicólogos eles só ouvem, não falam nada. 


\section{$[\ldots]$}

Então, na... você sabe que na Grécia, a... na... acho que você já deve ter lido, não preciso te falar mais nada, mas continua. [Não? Pode falar, eu não sei do que você está falando.] Não... você estudou, eu não estudei, não sei do que você está falando, pô? Continua.

$$
\text { [...] }
$$

Porque você tem que viver pra você saber, não preciso te falar.

$$
\text { [...] }
$$

Eu tô falando, cara! Mas eu tô ficando quieto que eu tô aprendendo que o negócio é calar a boca!

\section{A violência na impossibilidade de desejos futuros}

[O que você gosta de fazer na vida?] Não tem o que eu gosto de fazer na vida... [Tem o que você não gosta?] É... que eu não goste? Também... acho que é tudo na hora, tudo ali, você vai saber, até coisa que eu não gostei e fiz, depois... na hora que eu fiz, eu falei puta que merda! Que merda! Que merda! Mas aí você vai e as coisas estão indo e... é uma fita, né malandro? o que foi gravado já foi gravado (risos) não dá pra voltar (risos) entendeu?

[...]

... eu só vivi coisa ruim, só isso... acho que por isso que eu sou do bem (risos)

$$
\text { [...] }
$$

$E$, que talvez role amanhã um trampo e que se Deus quiser vai rolar mais, né? Pagar o aluguel, comer...

$$
\text { [...] }
$$

Não, não, deixando a vida andar não! A vida não pode andar, você tem que andar, né?

$$
[\ldots]
$$

Não... não tem nem pensar, o negócio é na hora, a gente tem que ver ali na hora, eu não tenho, não falo assim "ah, é isso ou não é" entendeu? Porque... nunca foi assim, cara, comigo... eu sou meio 8 e 80, sabe assim? Meio espuleta, sabe pimentão, pimenta, sei lá.

$$
\text { [...] }
$$

Ah eu não acho nada, só na hora, só quem vive aquela coisa que sabe, eu não sei porque eu não vivi aquilo. O que eu vivi eu na hora lidei, eu depois bati com a cabeça e quase me soquei (risos) tá ligado? Sei lá...

$$
\text { [...] }
$$

[Do hoje você pensa no amanhã? Ou do hoje você pensa o hoje?] Só na hora mocinha... (risos)

\section{A possibilidade do desejo - não repetir uma história - a raiva aparece}

[Mas você morou na rua, né?] Morei. [Hoje você moraria?] Oh, eu vou te falar a verdade assim, se precisar cara, eu tô aí, tá ligado, só que eu fazer de tudo pra não, não fazer isso, mas... eu não quero, e tipo assim, se acontecer meu, desculpa aí, tá ligado? Eu tô aí, quem quiser me ajudar me ajude, quem não quiser, firmão, eu sou um cara do bem, eu... se não der certo firmão, eu não vou me matar que eu não sou covarde, tá ligado? Agora eu não sei porque você falou se eu não moraria na rua... [...] Eu acho que você não deve nem pensar nisso, né? Acho que a coisa é pensar 
positivo, sabe assim, eu penso positivo todo dia, eu desejo coisas boas pra todo mundo e... o que desejarem pra mim, sabe assim... é isso aí cara, eu não penso nada disso e eu acho que você não deveria nem falar isso, desculpa. Tá ligado? Eu não sou seu pai, sua mãe, nem sou mais velho que você, mas eu acho que você não deveria nem pensar isso... [Do que eu não deveria nem pensar?] Isso que você falou, não quero nem repetir, nem pensar nisso, isso aí é uma coisa ruim, sai daqui...

\section{A possibilidade de sonhos - implica-se neles?}

[Qual é seu maior sonho?] ... meu maior sonho não dá pra te falar porque não tem um maior assim... [Tem muitos?] É, sei lá, acho que todo mundo tem todos, né? Quer ter tudo, eu sou mais simples, vim debaixo, mas eu quero ser alguém, ser uma pessoa de bem, sabe assim? Fazer o bem, é... ter o que eu não tive, dar uma boa vida pra minha mulher, que eu tiver e... sei lá, é isso, viver, viver bem, sei lá... poder viajar, conhecer os lugares, a... mesmo que eu não seja um artista, a... continuar fazendo o meu barro, a... mesmo que eu não vire um câmera, continuar filmando, mesmo que eu não seja um cantor, ou um compositor, mas continuar fazendo o que eu faço, ser o cara simples que eu sou, entendeu? Assim e devagar e sempre a gente tá aí. Entendeu?

$$
\text { [...] }
$$

Eu queria estudar numa escola boa, sabe assim, manja assim? Aprender, sei lá, fazer uma USP, alguma coisa assim, sei lá, ou senão, só Deus sabe, só na hora, né?

$$
\text { [...] }
$$

Eu acho que se você aprender um pouquinho de cada coisa, na sua cabeça você constrói uma outra coisa...

\section{A violência da corrupção}

É... eu fui pego aí... inclusive eu trabalhava na Cosesp, a... eu tinha tíquetes no bolso, assim, a carcereira roubou meus tíquetes, tá ligado? O delegado falou que se eu pagasse pra ele, ele não faria nada e depois eu tive que comparecer... 


\subsection{Douglas - a (des)confiança e a violência sentida}

\section{A ausência sentida - a falta do pai; a necessidade de trabalho da mãe para sobrevivência financeira da família}

...daí o que acontece... várias dificuldades em casa, problemas com a família, como que eu fui assim criado pela minha mãe, meu pai eu conhecia, só que ele morava longe e eu ia visitar ele de vez em quando, chegou um tempo que eu não visitava mais ele... [...] Quando eu não via mais eu tinha uns... quando eu nunca mais vi ele eu tinha uns 9 anos de idade. Daí o que acontece... eu comecei a vim pro Mutirão, estudei no Mutirão tudo, que foi uma ótima coisa, só que, como você não é criado pelos pais, você sempre tem uma festividade na escola, dia dos pais... como eu fazia teatro é... até aqui no Mutirão, na escola, isso aí, sempre tinha aqueles brinquedinhos, aqueles bagulhos pra dar pros pais, tudo, eu pegava e não tinha pra quem dar, via as crianças abraçando tudo ali e você ficava assim mal... que você ficava sentido, porque você não tinha ninguém ali pra você está comemorando junto, a única pessoa era a minha mãe, minha mãe trabalhava muito como funcionária pública...

\section{O fracasso da escola}

Porque eu era... vamos se dizer assim, eu era a criança problemática, né? Chegava as molecadas, falava coisa pra mim e eu batia neles... é... eu era ignorante, era traste ruim como que dizem os baianos, então o que acontece, daí batia, quebrava vidro da escola é... pichava... é... tinha época de gang também, de pichação, daí o que acontece? Sempre arrumei encrenca dentro de escola e não prestava muita atenção na aula, queria mais namorar, não prestava atenção, fugia de casa às 11 h da manh... da noite pra ir pro salão na sexta-feira com 11 anos de idade e assim foi indo, minha vida sempre foi nessa, nesse... nesse seguido, né? Daí o que acontece? Eu ia pra escola, tudo, mas não prestava atenção, daí teve umas... é... umas psicólogas que... esses negócio de escola, daí fez um... psicologia, um negócio comigo, uma consulta comigo, daí falou pra minha mãe que eu precisava de mais atenção, que eu tinha que ficar em sala particular... [Tipo especial, como assim?] Isso, sala especial...

\section{A necessidade de trabalho precoce}

...daí eu comecei adolescente tudo, comecei a trabalhar tudo, daí eu ganhei uma oportunidade de serviço, já conhecia as pessoas da malandragem, já conhecia as pessoas certas, as pessoas erradas, daí eu falei "mãe, arrumei um serviço como entregador de pizza"...

\section{A marginalidade presente na periferia espreita a formação do adolescente pobre}

... daí ela pensou, ela e meu irmão mais velho pensou que eu ia catar a moto pra ficar zoando, aprontando por aí pela rua, daí ela falou "não vou te dar!", que não sei que, dai eu acabei discutindo com minha mãe, com meu 
irmão, também não quero mais nada de ninguém, não quero saber, "já que vocês não vão me ajudar então eu vou me ajudar do meu jeito, vocês não podem me arrumar o dinheiro, então eu arrumo do meu jeito”. Aí eu comecei a roubar, conhecia já amigos meus que roubavam, comecei a roubar, né? Ia no supermercado, tudo...

$$
\text { [...] }
$$

então o que acontece, você pede uma ajuda pra uma pessoa pra você não entrar e às vezes por conseqüências da vida, você acaba entrando nessa, nessa vida, não... uma coisa, vamos se dizer, te obriga, você olha ali, você, você procura arrumar um serviço, uma coisa, mas você não consegue, por causa que... hoje em dia, se você tiver idade demais você não arruma mais serviço e se você tem a idade, pede a experiência, como você? Você acaba de fazer um curso disso, mas como que você vai ter um ano de experiência e carteira assinada, sendo que ninguém te dá uma oportunidade, então o que acontece, daí você olha ali, você vê um cara ali que tava roubando, vendendo droga e sempre com dinheiro, sempre com ... [...] O tempo todo, ainda vejo porque ainda conheço, hoje eles no lugar dele e eu no meu lugar, cumprimento, tudo...

$$
\text { [...] }
$$

Daí depois disso que nós fomos confundidos com esses rapaz do PCC, esses ladrão aí, daí o que acontece? Que nós mudamos totalmente a nossa mente: "Agora nós vamos roubar mesmo de mão armada e se vier alguém nós vamos mandar bala pra cima". A vida acaba criando você desse jeito, a rua, entendeu? Às vezes, um adolescente, o que ele quer, ele quer um pouco de atenção, se você que nem... nessa época, tudo, eu vendi drogas também na rua, tinha biqueira que (...) mesmo tendo meu próprio ponto, então o que acontece, é... às vezes chega um adolescente que você... chega ali ele está com problema dentro de casa e às vezes o que ele recebe mais um carinho, um conforto é do cara que tá na biqueira, que está ali na droga, então o que acontece, chega ali "não, o que foi, senta, vamos conversar, não, mas isso é coisa que acontece..." sempre está colocando a pessoa pra frente e vai puxando mais a juventude pro lado dele.

$$
\text { [...] }
$$

que eu acho que até os seus 16 anos, 17 anos tem muito adolescente que ainda não sabe o que faz, tem influência, influenciado por outros, pelos amigos, tipo, vai lá, nós dois, nós consegue, nós tamo sem dinheiro pra ir pra festa, pro baile, vamos lá catar não sei que ali que é fácil, né?

\section{A violência do silêncio - a falta de diálogo na família e na escola}

Falta conversa entre os pais, hoje em dia tem mais pessoas é... assim... que não é da família, pessoas assim que dão uma explicação pra nós, que nós precisava ouvir do que, dos nossos pais, das nossas mães, que mulher você recebe mais é... da tua... conversam mais com a mãe, né?

$$
\text { [...] }
$$

Tem que ter muito diálogo... hoje em dia também os professores... hoje em dia, que falta mais o diálogo, carinho do professor, (...) Tem que ter mais carinho, amizade, você vê que aquela criança está tendo problema dentro de casa, né? Que você percebe, então você tentar adquirir aquela criança pra você, ela sempre está ali, não, se sentir querida, pelo menos por alguém, daí é isso...

$$
[\ldots]
$$


Ah... não tinha... não tinha mais um... como ela falava, "não faz isso", eu chegava e falava "vou aqui no supermercado, né?" encontrava com uns amigos meus nesse supermercado e eu ficava 3, 4 dias sem aparecer dentro de casa... eu andava todo de preto, de coturno, calça rasgada, ia pra cemitério, voltava, maquiagem na cara, batom preto, esses negócio tudo e voltava depois de 4 dias... Quando eu falava "ah, vou ficar uns 15, 20 dias" eu ficava uns 6, 7 meses sem aparecer em casa, eu sempre sumia, desaparecia sempre, dai comecei a freqüentar, a fazer delito, 155 e assim foi indo... foi crescendo... e chega uma hora que a juventude fala é o seguinte "chega, quero alguma coisa que ou me dá dinheiro mesmo ou... né?" Alguma coisa assim...

\section{As brigas de gang}

Que... eu curtia rock também... a qual eu comecei a usar droga depois que eu comecei curtir rock, que eu curtia som gótico, ia pra cemitério, dormia dentro de cemitério, com gangs, né? Que era os góticos, tinha punk do lado, skinhead... batia, dava facada, esses negócios tudo...

\section{Os acordos possíveis, a violência da corrupção}

... aliás ele é semi-aberto pra quem tem dinheiro porque você tem que sair pra fora, você sai pra fora de manhã... [...] Que nem, eu falo que é pra quem tem dinheiro, por quê? Porque tem muitos esquemas lá dentro que muitos compra a carta de emprego, dai sai pra fora, volta a roubar, paga os $R \$ 300,00$, daí desses $R \$ 300,00$ fica acho que $75 \%$ pra casa, $20 \%$ pra tá... é... conta liberdade, né? E o resto você pega $R \$ 220,00$ no final do mês...

$$
\text { [...] }
$$

daí já acharam nós pelas roupas, pelas bicicletas e nós fomos preso de novo, fomos eu e eles, assinamos 157 e 288 que é formação de quadrilha, com 4, com 5. Daí um foi embora porque os polícia conhecia ele e liberou ele por causa que ele trabalhava num negócio... num bar, numa lanchonete em S., que o dono de lá era policial também e daí como eles conhecia, soltaram ele. [...] Não pagou nada, quer dizer falaram "quando nós for lá vocês vão liberar umas feijoadas pra nós". "Não, pode ir que está na minha conta!" Aí soltou ele.

$$
\text { [...] }
$$

[Como o celular entra?] Ah, entra pelas mulheres e também, como agora que tem por causa do raio x que tá tendo agora, ele não mostra, mas ele apita se passar, então o que acontece, não entra mais, entra agora pelos próprios funcionários mesmo. [Eles querem o que em troca?] Dinheiro, tá na faixa de 3 a 4 mil reais pra poder você estar com um celular bom lá dentro. É, informação também, mas isso é mais do pessoal que é da faxina, naonde que tem mais acesso aos funcionário.

$$
\text { [...] }
$$

[Tem acordo entre esse pessoal do Comando e os juízes?] Ah tem, tem, tem... o juiz hoje em dia... é... se você tiver dinheiro mesmo, você sai da cadeia... se você não tiver...

$$
\text { [...] }
$$

Você que já teve processo na justiça, você está vindo da escola ou de qualquer outro lugar, se o policial ele te para, se ele for com a sua cara ele só puxa o seu documento vê que você não tem nada, que você está limpo, que você está chegando de algum lugar, do serviço, eles vão e te solta, 
agora se eles não vão com a sua cara, eles mesmos jogam drogas no seu bolso, eles mesmo te prende por coisa que não tem nada a ver... isso... que nem tem muitos hoje em dia, policiais andam com drogas, passam em biqueira, né? Que chamam de biqueira, chega lá apreende as drogas, não prende os caras porque usam... tem vez que tem, você vê policial que está mons... monstruado, né? Que tá doidão, entendeu? Conheço amigo meu, policial também que fala "nossa, tem vez que os caras aqui, que eu tô lá, levam lá pra... pra C., nós corta os caras na bala, aí falam bem assim mesmo!" Que nem, isso eu escutei no próprio radinho, um amigo meu que tem os conhecimento com os polícia, né? Não é ladrão nem nada, aí eu escuto o pessoal falando pra ele no radinho "ó mano, você fica no gelo, não anda ali pelos F. da T. entre a rua 9, o barzinho da rua 9 e a rua 10, nenhuma lojinha, fala pra fechar tudo, porque se nós tromba alguém na rua nós vamos assassinar"! Então é assim, hoje em dia, polícia também que fala... vem ficar com o pessoal, que nem aqui já aconteceu na rua, que eu conheço, com droga, fala "ó, pra nós te soltar nós quer 10 mil, 5 mil, 7 mil", teve a vez do meu primo que não tinha nada a ver com crime nenhum... é... pra ele sair da rua que quando mataram um policial, atiraram num policial, aí prenderam ele, falou que se ele não pagasse 7 mil que eles iam jogar esse crime nas costas dele... e teve que pagar, né? A situação é... sujeita, eles pedia, tem que pagar e que eles às vezes você paga, cê pensa que está firmão e eles tão aí cada vez querendo mais, isso... a corrupção é muito grande, uma corrupção muito grande...

\section{A violência do assalto contra uma vítima violentada pelo álcool}

...dai eu andando de bicicleta, eu mais meu primo, mais 2 amigos nossos, aliás, 3... daí... 2 amigos nosso viu um rapaz alcoolizado na rua, daí falaram "vamos tomar ele", daí os moleques foram, tomaram ele, tudo, daí nós indo embora, paramos no $H$. aqui na C., daí fomos atua... atualizado, preso de novo...

\section{A violência do sistema: polícia, cadeia, fórum, Febem}

... precisava de dinheiro que eu queria fazer a minha festa de aniversário, queria ajuntar que a gente estava com problema com polícia também, que tinha confundido eи e o meu primo com outra pessoa, não, queria matar nós mesmo, por causa que tinha um "irmão", um irmão do PCC, que chama, é... que chamava o mesmo apelido que meu primo, daí o que acontece, eles vem atrás de nós, que queria matar nós que pensava que era eles. Aí nós teve que sair fugido daqui... aí quando nós voltamos, nós falamos "não, não quero mais saber, rezamos, pedimos tanto pra Deus pra não entrar nessa vida, não adiantou, agora nós vamos entrar de cabeça, daí começamos a roubar, compramos arma, roubamos, compramos arma, fazendo festa toda semana, e assim foi indo...

$$
\text { [...] }
$$

Você fica uma noite lá aguardando o caminhão pra vir buscar os presos, né? Daí lá, nossa! É horrível, lá o chão é todo molhado, chão de concreto, cimento puro, todo molhado, o lugar não entra ar nenhum, cada rato que o rabo dele é quase do tamanho do meu braço... horrivel, horrivel, horrivel, horrivel, precária mesmo, tanto que, nós mesmo que estava ali, nós estamos pagando pelo que fez, não merece nenhum privilégio, mas ali a 
conseqüência é terrível, até o rato chegava a arrastar até o saco de lixo, de tão grande, de força que tinha.

$$
\text { [...] }
$$

Ah, pra castigar... só pra castigar. Daí saia de lá nós ia lá pra... como que é o nome? Pra... pro Hospital das Clínicas fazer perícia, mas que não adianta nada... [Vocês apanharam lá?] Não, eu apanhei no dia que eu fui preso, na delegacia, eu mais um amigo meu, tomamos umas bicas dos polícias... [...] Ah, eu acho errado, né? Porque ali nós já estamos, já estamos algemados, já não estamos mais armados, daí vai querer agredir, porque aí eu já acho que é abuso de autoridade, não é verdade? Agora se nós estivesse armado e eles também ou numa fuga e eles atirassem, aí ia ser uma defesa deles, tudo... Não criticando nem um lado nem o outro, que os dois lados são errados...

$$
\text { [...] }
$$

Os polícia lá dentro do fórum, bate... é porque sempre tem isso... nós tem... é como o fórum é uma coisa demorada, que você vai de manhã cedo, cê sai de manhã cedo umas oito horas da manhã, daí você vai e fica na inclusão do $C D P$, daí vem o Bonde, daí você vem lá, daí chega o Choque, daí você tem que tirar sua roupa todinha, bater no chão, abaixar três vezes, mostrar a língua, sobe pro Bonde, lá dentro fica maior demora, daí tem que fazer tudo de novo, daí você sobe lá dentro fica na cela até ter a sua hora de julgamento, daí bom, você já está cansado, morrendo de fome, que a única coisa que eles dão é dois pão com queijo e um suquinho, daí você quer ir embora logo, daí começa a gritar "olha o Bonde, solta nós, manda nós embora”, daí o que acontece, daí sempre tem algum bravo, policial bravo vem e joga spray de pimenta em nós, leva a gente pra uma outra cela, bate em nós...

$$
\text { [...] }
$$

Isso... dentro da cadeia... é... policial, Agente Penitenciário que agride nós, é... fala palavra até pras nossas visitas, cantam nossas visitas. Nossa... muito...

$$
\text { [...] }
$$

Que nem esse meu parceiro que foi preso a primeira vez, ele foi pra Febem, ele era menor, então eu conversei com ele e... tem muitas coisas ali que... você está assistindo, eles coloca a televisão lá pra você assistir, que é 1 hora, 2 horas de televisão, só que você tem que ficar lá sentado em posição, com as pernas juntas, cruzado, né? E de cabeça baixa, você não pode nem vê a televisão, se você vê você apanha é... o que acontece? Você ali tem coisas que é cortado, tipo tem... é vício, né, fazer o quê? Tem jovens que fumam, lá você pode pegar uma, um maço de cigarros pra dividir pra todo mundo e tem que durar até o próximo, até o outro dia, que acontece, um cigarro pra cada um e quem fuma, eu fumo mesmo, quem vai falar que consegue ficar um dia... você fica desesperado, atordoado, então com agressão com tudo, então nisso mesmo que eles vão quebrar, vão quebrar a cadeia, vão grudar os funcionários...

\section{O sistema desrespeita os prazos dos processos}

Dessa vez não, que da primeira vez eu fui da 39 direto pra Colônia, por causa que como eu recebi o semi-aberto direto, eles não podem manter você preso no fechado ou em qualquer cadeia, porque se acontece alguma coisa, cai nas costas do diretor, mas tem muitas pessoas dentro do CDP também que foi condenado na Colônia e está ainda... 3, 4, 6 meses ainda lá dentro 
que não poderia estar, então lá o que acontece? Você só tem o benefício se você... é... é lento. Se você tem um advogado que você paga pra ele pra estar recorrendo, funciona, mas não é tão rápido que se você estivesse no Fundão.

\section{A violência sentida na humilhação}

... sobre a roupa também, que a roupa nossa que nós usava era como se fosse uma roupa de... de lixeiro, né? Que é o coletinho laranja, a calça laranja, né? E fora que você vai pro fórum vestido com essa roupa também, sem tênis, de chinelo, aquela humilhação do fórum, e jogam spray de pimenta na nossa cara...

$$
\text { [...] }
$$

Isso, porque daí o pessoal do Choque nem entra dentro dos barracos, só entra só os próprios funcionários, só entra só pra escolta. Daí o que acontece, daí bagunça, joga nossas coisas tudo no chão, vira o barraco de tudo, depois nós temos que levar tudo de volta.

$$
\text { [...] }
$$

É... tinha viado morando conosco, travesti, né? Que eles moram separados, numa cama separada, não pode, que é ordem da cadeia, você não pode..., não dos policiais, dos agentes, dos próprios presos mesmo. Você não pode manter relação com... relação homossexual dentro da cadeia, daí o que acontece, eles guardavam o nosso celular, guardava dentro deles, é... eles guardavam drogas... Isso, e recebiam também por isso.

\section{Os castigos físicos - a violência da tortura}

Dentro do Fórum é isso, porque aí é lá embaixo, lá embaixo é só polícia, ninguém ouve nada, é tudo no meio deles, a única coisa que vê é nós, spray de pimenta na cara que... tossindo sangue, cuspindo sangue pelo nariz, porque sufoca, a gente vai tossir aquilo queima, é horrivel. Fora que também te manda tirar nossa roupa, joga spray de pimenta e aquilo onde cata queima.

$$
\text { [...] }
$$

Castigo é uma celinha, uma sala pequena, que só tem uma cama só, mais ou menos é uns 2 metros por 1 metro. Daí tem o banheiro, tem uma caminha, uma cama aqui e o chapão de ferro. Você só vê a muralha, mais nada, e até a comida que você recebe, você recebe pela uma frestinha que tem na chapa. Daí fiquei 8 dias lá, só saí mais cedo por causa da anistia do dia das mães.

$$
\text { [...] }
$$

A comida chegava... a gente ia pagar a alimentação é... 5 horas da tarde o almoço, o café, o almoço e o café, nós já estava roxo de fome porque já tinha chegado o Choque, já tinha arrastado tudo nosso, alimentação estragado que eles pisa é... depende, também depende da situação, né? Pisam, chutam, estragam nossas coisas, então o que acontece, nós já estava varado de fome, tinha vezes que era meia noite e estava chegando a janta, às vezes chegava, como nós foi pro castigo eu cansei de ver, porque você tem acesso à primeira portaria, aonde que fica que chega o carro da alimentação, a firma contratada que coloca ali no carrinho e depois vai embora e ali a comida ficava por várias horas... é... ficava ali na Radial debaixo do sol, às vezes chegava até meia morna e quando você ia pegar ela 
estava quente de tanto sol que já tinha ficado. E assim ia... no castigo, demoravam pra servir a alimentação...

\section{A rebelião - a violência dos e contra os funcionários e policiais}

Ficamos na nossa, daí no domingo que nós fomos tomar a cadeia, daí o Belém 1 virou e logo em seguida virou o Belém 2, só que nisso os Agentes já estavam preparados, já estavam armados, atiraram pra cima dos meninos que estavam no corredor e os Muralhas também, aí atiraram pra dentro das celas a qual teve três mortes lá dentro, teve um que estava na capa, morreu com um tiro de fuzil, né? Morreu ele e mais um outro com uma bala só, é... pessoas machucadas, foram mais de 18 pessoas machucadas, é... e... sem contar a agressão dos funcionários também, né? A qual que revoltaram mais os presos lá dentro, que teve pessoas, amigos nossos que estavam vivo e eles estavam ali futucando com ferro, enfiando ferro "morre agora seu P... seu Pececinho de merda" enfiando os ferros nos nossos amigos, nossos companheiros e nós vendo tudo...

$$
\text { [...] }
$$

...eu vi coisa que foi terrível... é os Faxina com pano na cara, com faca que nós mesmos teve... que nós mesmo amolamos pra poder grudar os funcionários é... Muralha atirando de (...) de fuzil pra cima de nós, amigos nosso perdeu metade de mão, perdeu dedo, tomou tiro, é... ficou por lá na enfermaria porque não saíram de dentro, não foram pra hospital nem nada, só sai se você estiver realmente morto, que nem, eu tenho um problema no pé, né? Aqui o pé quebrado, só que eu não ajeitei ele direito, então ele dói, que é fora do lugar, pra você fazer tratamento, não tem como, você fica do jeito que você está mesmo... eles te dão um remédio, mas uns remédio mixuruca, né?

$$
\text { [...] }
$$

Mas é o único jeito pra gente chamar a atenção da reportagem pra situação da população... que nem esses ataques, esses negócio, foi o modo de chamar a atenção, de parar São Paulo [refere-se aos ataques a bancos e delegacias, atribuídos ao PCC em 2006] pra ver uma coisa, colocaram... mandaram pessoas colocar placas na rua, tudo, pra explicar pra população que não era pra população, nós estava matando polícia, polícia, carcereiro que estavam realmente prejudicando nós, que nem... carcereiro que bate em nós lá dentro, machuca nós lá dentro e nós não pode fazer nada com eles lá dentro...

\section{As duas faces da mesma moeda - a violência dos e contra os policiais}

Isso... dentro da cadeia... é... policial, Agente Penitenciário que agride nós, é... fala palavra até pras nossas visitas, cantam nossas visitas. Nossa... muito... [Vocês viam?] Não, cê não via, mas chegava as visitas ficava atordoada, comentava, chorava e você lá dentro, você não podia fazer nada, a não ser se um dos Agentes, esses Agentes entrasse pra dentro e nós grudasse ele, é o único modo de nós defender e pedir pra dar algum direito pra nós.

$$
\text { [...] }
$$

... você fica desesperado, atordoado, então com agressão com tudo, então nisso mesmo que eles vão quebrar, vão quebrar a cadeia, vão grudar os 
funcionários, que nem lá no Belém que nós foi virar alguma coisa, a cadeia, que nem nós viramos na 39 também, nós avisava é... tinha funcionário que nós falava, "ó, amanhã é seu plantão, nem aparece que amanhã nós vamos virar a cadeia e dependendo quem tiver aqui nós vamos grudar". [...] Isso, nós avisava, pra não ter nada, nada acontecer com eles, né? Tem funcionários ali que trata você como gente, agora tem outros que trata você pior do que um cachorro, do que um bicho, então isso que acontece, acontece muito na molecada, na juventude e a juventude hoje em dia que ela quer ser mais malandra, né?

\section{A violência da discriminação}

Então, o que acontece, vi bastante pessoas que estavam dentro da cadeia, que a qual são acusados, foram condenados já pelos crimes que não cometeram, que nem, estavam passando em frente a um lugar que mataram uma pessoa, só porque os dois eram pretos, os dois foram autuados, como se diz, em flagrante, como se tivesse matado a pessoa...

$$
\text { [...] }
$$

...então hoje em dia, mesmo eu mudando meu jeito de ser, meu modo de andar, meu modo de viver, mas tem muita... como que eu chamo... é... pessoas é... julgam, ó lá, tá preso, foi preso... tem muita gente, muitas pessoas, tem mãe de amigos meu que não quer ver eles conversando comigo é... [...] que muitos lugares que eu vou tem amigos que eu conheço, que por sinal hoje em dia eu nem falo, nem tento lembrar, nem lembro do meu passado... falam ah, você viu, não sei que... aquele ladrão ali... misericórdia, não gosto nem de passar nessas ruas, já dou uma de nunca foi pego, nem conheço... mas hoje em dia é assim que eu vou levando a minha vida assim, desse jeito...

$$
\text { [...] }
$$

... eles sempre pede a ficha criminal, né? Consta como que se você tá... vamos dizer como se você está preso ainda, né? Você está devendo ainda alguma coisa. Então você não consegue, pela discriminação, a qual, hoje em dia, tem muitas pessoas que estão entrando na marginalidade ou continuam por falta de oportunidades...

\section{A ética na malandragem - a violência dentro do mundo do crime}

Pra você entrar tem que ter uma pessoa, um pouco mais... conhecida sua, que já tem um tempo no Comando, daí o que acontece? Ele vai trazer o estatuto pra você, você não pode cagüetar, você não pode estar se metendo em confusão, você não pode matar qualquer pessoa em vão, essas coisas... tem que estar sempre ali pra tentar resolver os problemas da comunidade e... pra você vender suas drogas, você está roubando tudo, mas longe, sempre mantendo a ordem na comunidade, no bairro, então o que acontece? Daí você tem um certo concerto com essa pessoa que é chamado "companheiro leal", que é "primo leal", daí eles vêm, pede o estatuto pra torre, pros general que são os que têm muitos anos, né? 10 anos, 11 anos de Comando, dai eles mandam, traz o estatuto pra você, o que você pode e o que você não pode fazer, daí eles vêm, ele e mais outro irmão e joga uma água na sua cabeça, está te batizando e te dá um estatuto, se você dependendo... e você tem que pagar uma caixinha todo mês é... se eu não me engano, acho que é de 1000 reais pra quem está na rua, quem está na cadeia, no CDP, são 200 reais. [...] Drogas, celulares, armas é... 
advogados, essas coisas toda, ônibus pra fretar pra família pra ir pro Fundão, que tem lugar, tem pessoal que é mais de 18 horas daqui pra lá, que tem famílias que não tem o dinheiro pra tá indo pra lá, então o Comando, eles dão o ônibus pro pessoal ir... então o que acontece? Se você fazer alguma coisa de errado pro Comando, então o que acontece? A única conta que você tem que pagar é com a vida, você morre, é decretado, entra mais... faz uma reunião com um monte de irmão, irmão da torre, tudo e faz aquela reunião, se vê que você está errado mesmo, você... é pedida a cabeça, então você perde seu papel, o estatuto e... é enforcado na hora... [...] Daí você tem que pagar todo mês uma taxinha, se você não pagar essa taxinha, você é excluído... [...] Você tem que pagar essa taxinha, se você não pagar você é excluído 15 dias de gancho, é... 15 dias de excluimento, se você não pagar, daí você é excluído de vez, dependendo do seu padrinho, se for um padrinho forte, com muito tempo de Comando, de PCC você mantém vivo, você fica vivo, senão você morre também..

\section{A violência do desemprego}

... você olha ali, você, você procura arrumar um serviço, uma coisa, mas você não consegue, por causa que... hoje em dia, se você tiver idade demais você não arruma mais serviço e se você tem a idade, pede a experiência, como você? Você acaba de fazer um curso disso, mas como que você vai ter um ano de experiência e carteira assinada, sendo que ninguém te dá uma oportunidade, então o que acontece, daí você olha ali, você vê um cara ali que tava roubando, vendendo droga e sempre com dinheiro, sempre com...

$$
\text { [...] }
$$

...então hoje em dia o que adquiri... só problema pra mim hoje em dia tenho 23 anos, não tenho grau de escolaridade bom, tenho uma passagem na justiça, então o que eu vou adquirir um bom serviço pra mim, um bom serviço que eu vou adquirir ou é de ajudante de pedreiro ou... qualquer outro, agora alguma firma você não arruma nunca mais... nunca mais... então o que acontece? Vou ter que ralar muito mais pra ter uma oportunidade...

\section{A dor materna - a violência de ver um filho preso}

Foi também... o fato também da primeira vez minha mãe teve uns problemas tudo, da primeira vez minha mãe teve um aneurisma cerebral, né? Um derrame... nervoso, né? Porque... eu preso e ela com problema no serviço... problemas com meu padrasto é... ajuntou com emoção boa que foi o casamento do meu irmão, ajuntou tudo isso, aí ela teve um AVC, né?

\section{A segregação da cidade}

...só que hoje em dia falta oportunidades pros jovens da... vamos se dizer, da Cohab, né? Moradias do bairro... porque hoje em dia muitas pessoas arrumam coisas assim, mas lá pro lado de Santana, Centro... longe, que é pra pessoas que têm dinheiro, pra jovens que têm dinheiro e os jovens que não tem dinheiro, que são pobre, não tem dinheiro pra onde sair... 


\subsection{Lucas - a vida em rebelião, a violência no dia-a-dia}

\section{A violência doméstica e o afastamento da família de origem}

Então, eu nasci no Bairro do Limão, na Casa Verde, morei lá na... ali na favela do Agreste, ali com a minha mãe, morei com ela até os 4 anos de idade... Então, morei no Bairro do Limão até os 4 anos de idade com a minha mãe, por dificuldades, que a minha mãe bebia muito e eu que tinha que carregar os meus irmãos nas costas e o pessoal, os vizinhos resolveu chamar o SOS Criança e nisso que o SOS Criança veio e tirou nós, eu e meu irmão da nossa mãe... [...] Chamaram o SOS Criança porque minha mãe batia demais na gente e ela bebia demais, aí a gente foi parar no SOS Criança, aí eu e meu irmão ficou no SOS Criança, desde os 4 anos até os 9 anos de idade. Depois, nesses 9 anos de idade a gente foi morar com, foi morar com um Padre, o Padre Jaime lá da Pompéia, aí a gente morou um tempo com ele, morou acho que 3 anos com ele...

$$
\text { [...] }
$$

porque não adianta eu fazer que nem meu pai fez, ou que nem minha mãe fez, me colocar no mundo e me jogar pro SOS Criança, entendeu?

$$
\text { [...] }
$$

... porque tipo, eu não tive aquela criação de pai e mãe, entendeu? Pai e mãe desde pequeno, eu tive até os 3 pra 4 anos, entendeu? O que eu fui criado mesmo foi em orfanato, entendeu? Fui criado em orfanato e aí conforme eu fui tendo idade fui passando pela minha família...

\section{O fracasso da escola}

Então, eu tava e não tava entendeu? Escola... tipo que nem eu falei, eu não tive aquela pessoa pra falar "pô, escola é fundamental pra sua vida, pro seu futuro..." entendeu? "Você vai ter prioridade numa escola..." então não, ninguém me falava, então não me via...

\section{A marginalidade presente na periferia espreita a formação do adolescente pobre}

Então a gente começava a tipo, a ter uma amizade diferenciada, um chegava "e aí, vamos fazer isso, vamos fazer aquilo" aí a gente não, não sei que, mas tudo começa, sabe, tipo, você quer comer uma bolacha você não tem dinheiro, tudo começa ali no mercado, no mercado do lado da sua casa... a gente vai pegava bolacha, pegava Danone e assim começava 155, 155 escondido... aí nisso eu comecei a... comecei a andar com esse pessoal, tudo, mas nunca chegava a me envolver com eles... aí chegou o tempo que eu queria tênis, queria roupa, queria aquilo, sabe, ninguém me dava... então eu comecei a... roubar, comecei a roubar, aí eu comprei minha arma...

$$
\text { [...] }
$$

Chega nesse limite... que nem esse meu parceiro que eu estava falando que... ele, a mãe dele e ele deu uma força pra mim, pra mim passar o final de semana lá, ele... tipo... ele não tinha passagem nem nada, ele trabalhava na Vega, tudo... e ele tipo, sabe? Foi um menino sossegado... aí conforme foi passando esses tempos, ele começou a ter uma amizade diferente lá, entendeu? Começou a ter uma amizade diferente, aí mesmo trabalhando ele começava a roubar, com 18 anos! 
[...]

[E quando um garoto novo entra nesse mundo, comete uma infração, o que você acha que leva ele?] Uma lição de vida... acho que não adianta a família conversar, não adianta... tipo... você dar conselho, eu dar conselho, a gente tem que passar por isso pra saber qual que é a realidade, entendeu? [...] Ao masculino e ao feminino também, que... hoje em dia é a mesma coisa, porque... na parte como eu fui ver, quando eu fui gravar lá a Febem das meninas, nossa! Tinha menina ali que você olhava, falava "meu, que você está fazendo aqui?" entendeu? Porque tinha menina que não precisava daquilo, é isso que eu estou falando... as pessoas precisam, precisam passar por, precisam ver como que é pra aprender, porque tem menina aí que tem pai, tem mãe, tem vida boa aí e fica... vai roubar! [Você tem idéia do que leva elas a roubar?] Amizade! Amizade... amizade... amizade e liberdade da mãe e do pai, tipo, pode sair, pode fazer o que quiser, tudo começa no baile, né? Vai a primeira vez num baile, aí faz a segunda vez, você vai pegando amizade, amizade, amizade, quando você vai ver... "ah vamos ali fazer não sei que", aí você faz a primeira vez, dá certo, faz a segunda vez, dá certo, aí você não pára mais, enquanto você não... não vê aquele objetivo: você morre ou você sobrevive e vai preso, você...

$[\ldots]$

... porque, na porta de casa todo dia bate lá... "ô, vamos fazer uma fita, trabalha aqui numa boca, ou faz isso e aquilo..." entendeu?[...] É... esse caminho bate na porta da sua casa, esse caminho bate, todo dia, todo dia bate, então... pra você ser forte é difícil, é difícil... que nem numa rebelião, uma rebelião você... não é, o pessoal fala, uma rebelião é dentro de cadeia, não... rebelião é o dia-a-dia, entendeu? Rebelião é o dia-a-dia... cada dia você tem que vencer uma rebelião, senão você... perde ela completamente...

$[\ldots]$

... você vê ali, você pô... você está ali conversando de repente chega um e pá, matou o maluco aqui na sua frente, entendeu? Isso acontece diariamente... entendeu?

\section{A violência da discriminação}

Como que pode isso daí acontecer? A pessoa faz tudo certinho, ninguém aceita, agora quando acontece alguma coisa... e tipo essa secretária aí, ela sabia que eu tinha passado pela Febem, entendeu? Que minha chefe confiava tanto nela que foi e falou e tipo, eu tinha falado pra minha chefe: "ó, não fala pra ninguém que não é bom, não é todo mundo que tem esse pensamento que a pessoa mudou, que a pessoa está afim de fazer o trabalho, tudo, não é todo mundo que vê desse jeito, é não sei quê." e acabou contando pra ela, acho que em um bate papo delas... todo mundo falava bem da gente lá, acabou contando, entendeu? E eu acho que ela julgou nisso, porque eu tinha passado pela Febem.. é... pra mim tinha a ver com isso, entendeu? E essa T. do RH também sabia porque ela que tinha me colocado lá, né? Aí tudo bem, né? Aí...eles pegaram e me mandaram embora, eu peguei e falei: ó, não vou assinar, eles queriam que eu assinasse a demissão, né? Eu peguei e falei: eu não vou... não vou assinar nada enquanto eu não falar com o pessoal do sindicato...

$$
\text { [...] }
$$

Tem que ver nessa forma... acho que... é... a televisão tinha que decatar o menor, não só o menor, mas o preso mesmo, que quando sai, alguns tenta se recuperar, tenta procurar um trabalho, tenta mudar de vida e não... as 
pessoas vira a cara pra eles, entendeu? As pessoas não olha do mesmo jeito que, tipo... ah, eu não passei pela Febem, eu não passei pela cadeia, então eu tenho prioridade dentro do trabalho e aquele que passou, mesmo aceitando ele, fica com pé atrás, porque se some alguma coisa, vai culpar quem? Aquele que não teve passagem? Entendeu?

\section{A violência do desemprego}

Aí como que a Novolhar tá, sabe? Não está tendo freela, não está tendo essas coisas, então eu tô procurando vários empregos, entendeu? Porque eu não quero, eu não procuro ter aquele pensamento, pó, tô precisando eu vou roubar, roubar sabe? Por que eu sei que hoje eu tenho 22 anos, já... eu sei que, se eu for preso, ninguém, ninguém vai... depois... é... tipo, eu não vou conseguir recuperar minha vida, entendeu? Mesmo... eu tendo minha casa, eu tendo minhas coisas eu não vou conseguir voltar pra... que isso daí vai me prejudicar, então meu pensamento é o quê? É eu conseguir fazer alguma coisa, entendeu? É eu chegar e... bom.. vamos... o que que tem pra mim fazer, sabe? E qual o trabalho que tem? Se não tiver nada na parte que eu gosto de câmera... alguma coisa, qualquer trabalho, entendeu? Eu saio procurando por aí, entrego currículo todos os dias... acordo cedo, vou lá no sindicato, no... sindicato em Santo André que eu moro lá perto, eu moro em São Mateus, mas fica do lado, aí eu vou pra vários lugares entregar currículo, tipo eu não abaixo minha cabeça, entendeu?

$$
\text { [...] }
$$

... que nem... a maioria não consegue emprego, a maioria rouba porque não consegue emprego, daí... precisa alimentar a família, não consegue emprego, não consegue aquilo, que que eles vão fazer? Aí... todo mundo fala, aqui não tem trabalho pra menor, ou... tipo... não tem trabalho pra quem não estudou... tipo isso, entendeu? As pessoas vão acatando isso, vão acatando isso... e começam a se envolver com as pessoas que... sabe? Trabalha na boca... começa a vender droga, começa a passar droga, começa a... fazer uma fitinha aqui, começa a fazer uma fitinha ali, então quando você vai ver você já está totalmente envolvido, entendeu?

\section{A ética na malandragem - a violência dentro do mundo do crime}

Sozinho, nunca gostei de ir com alguém porque era, eu achava que era trairagem, porque se você pegasse uma coisa alta, aí um podia ser traíra com o outro, que nem acontece várias ocasiões que um chega a matar o próprio amigo por causa do dinheiro.

$$
\text { [...] }
$$

Ah... a gente aprende muita coisa...muita coisa... ah, a gente aprende que... que nem as pessoas falam, o mundo do crime não é um lugar de diversão, entendeu? Mesmo você... pô, você pode ser considerado o que for... você pode ser o bandido que for, você tá lá dentro... você deu um pezinho, alguma coisa errada, neguinho vai e te mata, ninguém quer saber se você é... um bandidão ou se você é um zé ninguém, entendeu? Então isso as pessoas começam a aprender, tem muito adolescente aí que completa... que começa a completar 18, 19 anos, vai preso e não agüenta... não agüenta o... aperto lá dentro, porque é... é... ali é um lugar que... meu! 


\section{A violência do sistema: Febem}

E mais velhos... e assim... tipo eu não via, eu não via inspiração pra mim lá dentro, tipo, eles falam que Febem resgata, é pra resgatar os adolescentes, mas ali tem... fica totalmente no mundo do crime, ali não tem resgate, ali é pra você se afundar cada vez mais... [...] o trato... o... como é que se diz, o trato da pessoa, o trato do ser humano, entendeu? Eles não tratavam a gente bem, tratavam a gente mal e a gente ficava mais trancado do que saía pra jogar bola, saía pra estudar, então a gente não via vantagem em nada, então o que que a gente fazia, a gente ia fazer rebelião toda hora pra fugir, entendeu?

$$
\text { [...] }
$$

É... várias mudanças, porque a gente tem uma passagem por... pelo um lugar, tipo pela Febem... a gente já, a gente já tem noção... é só a gente mesmo ter olhar do que que é o mundo, não adianta uma pessoa que nunca passou... ou fez faculdade, fez isso e aquilo, chegar e falar a Febem é isso, é isso, é isso, a televisão, ela mostra a Febem uma coisa, entendeu? [O que que é a Febem, você que passou por lá?] A Febem é... um lugar, na onde, na onde te leva, te leva ao mundo do crime praticamente, te leva a uma continuação do mundo do crime, não tem... como é que se diz? Não tem uma... a revolução, não tem uma ajuda especial, entendeu? A televisão mostra a Febem tipo Tatuapé, lá os menor tem atividade, tem isso, tem aquilo, mas ali Tatuapé, e os outros lugares e as outras Febem... eles esconde, eles esconde Franco da Rocha, eles esconde Parelheiros, entendeu? Hoje em dia eu não sei como que está, que deve ter mudado algumas coisas, mas eu acho que está do mesmo jeito, do jeito que estava... a gente mal chegava, a gente já apanhava, entendeu? A gente já apanhava e como você vai se recuperar num lugar que você já chega apanhando...

$$
\text { [...] }
$$

Não... é... eu acho que as pessoas... as pessoas deveriam, tipo a Febem, a Febem tinha que dar oportunidades pra... pras pessoas de fora ver como que é lá dentro, mostrar o mundo real, não um mundo falso, entendeu? Mesma coisa na cadeia, na cadeia eles falam... é, presídio bonito aqui... fiz outro ali, fiz outro ali, mas e o dia-a-dia daquelas pessoas, entendeu? Que nem tem... na onde que o Fernandinho Beiramar está lá, você fica na cela o dia todo sem poder fazer nada, é mais fácil a pessoa se matar, entendeu? Ficar trancado ali no local o dia todo, você não vê ninguém, não vê sol, não vê nada e aí isso é vida pra o ser humano? Como é que a pessoa vai se recuperar daquele jeito? O que que ele vai fazer? Vai fugir e continuar aprontando... porque não tem, não tem um... uma ajuda pra eles, não só pra eles como pras outras pessoas...

\section{A violência do silêncio - a falta de diálogo na família e no trabalho}

...na semiliberdade a gente podia todo final de semana ir pra casa, né? Ficar com os familiares, e nisso meu, meu avô, ele não me aceitou de volta, ele não me aceitou de volta e isso foi inspiração nenhuma, falei: ah, ele não me quer de volta, não tenho mais ninguém, então eu vou... me afundar, entendeu? Eu tô nessa vida, eu vou prosseguir do jeito que eu estou aí...

$$
\text { [...] }
$$

Não, a T. do RH, falou “ó, você está sendo despedido por causa disso...” eu peguei e falei: ó, vocês podem me mandar embora por justa causa se for eu, mas eu quero que vocês me provem que foi eu, né? (...) eu peguei e falei, ó 
se vocês me provar que foi embora, que... que eu fiz isso, vocês podem mandar por justa causa, eu não quero receber nada, entendeu? Aí ela pegou e estava enrolando lá, ficaram enrolando, ficaram enrolando e pegou e falou "pode trabalhar normal", (...) Aí eu voltei no outro dia, quando é... (...) aí essa... a secretária que estava de chefe lá, ela pegou e me falou "ó, a Tânia quer falar com você lá no RH”, aí eu fui lá, peguei e falei: pode falar que está na hora do jornal e eu tenho que voltar correndo, senão atrasa tudo lá, ela pegou e falou "não, você não precisa voltar, você está sendo despedido." Aí eu peguei e falei: não, mas cadê? Vocês provaram? Aí ela falou tipo "não, isso aí é o chefe... chefe, não sei que que está mandando e a gente não pode fazer nada" entendeu? Aí eu peguei e falei: pó, mano, mas assim vocês acabam comigo, entendeu? [...]

\section{A violência do dia-a-dia}

É... esse caminho bate na porta da sua casa, esse caminho bate, todo dia, todo dia bate, então... pra você ser forte é difícil, é difícil... que nem numa rebelião, uma rebelião você... não é, o pessoal fala, uma rebelião é dentro de cadeia, não... rebelião é o dia-a-dia, entendeu? Rebelião é o dia-a-dia... cada dia você tem que vencer uma rebelião, senão você... perde ela completamente... [Como que é essa rebelião do dia-a-dia?] Rebelião no diaa-dia é você... é você acordar... saber que você... saber que você pode conseguir um trabalho, ou se você tem um trabalho, você vai pro trabalho, faz seu trabalho, volta pra casa, se tá... ao deitar da noite se está tudo bem, entendeu? Não aconteceu nada com a sua família, não levou uma bala perdida, não levou isso e aquilo, não foi roubar, não foi fazer nada... isso é uma rebelião, entendeu? É você vencer o dia, entendeu? Você não deixar o... tipo... o capeta te dominar, porque ... assim, mesmo... mesmo, tipo... você tendo... você tendo as coisas, você quer ter mais, você quer ter mais, então... toda hora vem aquela maldade no seu pensamento, então você tem que matar aquilo, entendeu? Você tem que matar... então eu acho que isso é uma rebelião... uma rebelião da sobrevivência do dia-a-dia, tipo que nem... até seu próprio vizinho, até no seu bairro mesmo, que... como que a gente diz, na cadeia, acontece alguma coisa você debate, você debate... entendeu? Se o maluco está errado, se você está errado, você passa pelo errado e... tá tudo bem, entendeu? Tipo, tudo bem naquele termo, né? Não está nada bem, mas também não está tão difícil... e aqui fora é tipo, aconteceu alguma coisa, você vai debater, não tem debate, não tem debate, é bala que rola, entendeu? Ou você morre ou você sobrevive, entendeu? Aqui fora é assim. É isso que é uma rebelião, entendeu? Lá dentro você tem que ser humilde, aqui mais humilde ainda, você tem que saber levar as pessoas, tem que saber conversar com as pessoas, mesmo... mesmo você não querendo, tem sempre aquele que quer desarrumar com você. (...) A gente tem que ocorrer com tudo isso, e isso daí acontece com todo mundo, tipo você tem um carro, você sai daqui, ali em um farol, neguinho vai e te assalta, entendeu? Isso é... é uma rebelião perdida... você perdeu o que você lutou pra pagar pra ... porque ali você não vai ter de volta, se a polícia não consegue pegar, você nunca mais vai ver seu carro, entendeu? Eu acho assim... 
Como foi possível observar na apresentação das entrevistas, alguns tópicos coincidem para os quatro jovens entrevistados. Esse aspecto foi proposital no recorte das entrevistas. Dessa forma, foi possível salientar o que há de comum e o que há de singular nas violências sofridas pelos jovens em suas vidas.

Todos eles sofreram inúmeros tipos de violência e relatam a falta que sentiram de ter alguém para dialogar, alguém em quem poderiam confiar e de quem receber orientações - falha das instituições família e escola, inexistência de instituições de cultura e lazer. Para saírem da vida do crime, relatam que precisaram confiar em alguém. A necessidade do encontro com o outro, como será apresentado em capítulo oportuno.

As contradições e ambigüidades então presentes nas falas dos adolescentes, afinal eles vivem em um mundo de contradições! Está presente também a possibilidade de superação das contradições no encontro com outro ser humano! E isso é necessário resgatar quando se trabalha com esses jovens. 
Capítulo 6 - O PROCESSO DE EXCLUSÃO E O FETICHE DAS MERCADORIAS 


\title{
6. O PROCESSO DE EXCLUSÃO E O FETICHE DAS MERCADORIAS
}

\begin{abstract}
[...] Nós necessitamos a aparição: o surgimento da natureza, o surgimento dos seres e, de modo decisivo, o surgimento dos outros homens (...) A reificação é um bloqueador de aparências, interrompe nas coisas, nos animais, nos homens o seu poder de aparição. (...) As aparências bloqueadas são aversivas. No racismo, a pelo do negro parece deixar de contar como uma pele que faz aparição de um homem. (GONÇALVES FILHO. 1995. p.155)
\end{abstract}

A constituição de muitos países se funda na defesa do direito à vida, à liberdade, à igualdade e a autonomia do indivíduo em face das instituições, contra a arbitrariedade dos poderes constituídos. Essas premissas, apesar de positivas frente a uma história anterior, subordinam-se ao direito à propriedade, trazendo implicações individualistas e desigualdade social. (SALES. 2004. p.28)

“A história dos direitos é também uma história das classes sociais e dos projetos sociais em disputa. Uma história de lutas sociais, de forças históricas em confronto, cada qual com o objetivo de tornar dominantes suas concepções e interesses, bem como uma determinada forma de cultura e sociedade." (SALES. 2004. p.34)

No Brasil, as pessoas não partilham das mesmas possibilidades, mesmo que sejam considerados iguais politicamente. $\mathrm{O}$ que é considerado uma infração para as pessoas pobres, é visto apenas como um desvio de conduta quando a mesma situação é cometida por uma pessoa que pertence às camadas médias da sociedade.

Os reais fundamentos da sociedade brasileira são o individualismo egoísta, a desigualdade, o privilégio de alguns, a desumanização de grande parcela da população. 
A criminalização ${ }^{16}$ dos atos de uma classe social (pobres) ou de um grupo de pessoas que se aproximam pela faixa etária (os adolescentes) transforma em suspeito qualquer indivíduo de uma dada categoria, independente de sua atuação. Ao mesmo tempo em que individualiza o crime e descontextualiza a sua aparição na sociedade.

Nas palavras de Chauí (2000. p.90) ${ }^{17}$ citado por Sales (2004. pp. 83-84) “[...] essa naturalização [da pobreza], que esvazia a gênese histórica da desigualdade e da diferença, permite a naturalização de todas as formas visíveis e invisíveis de violência."

Ainda mais quando o Estado promove mais violência ao favorecer o grupo dos que possuem renda em prejuízo dos que possuem apenas a sua força de trabalho. O Estado tem a função de proteger os indivíduos uns dos outros, pois a não igualdade social entre os membros de uma cidade ou comunidade, ou seja, a diferença entre aqueles que possuem os meios de produção e as propriedades ou aqueles que detêm apenas a sua força de trabalho, impõem a rivalidade entre as partes.

O uso da força e até da violência foram legitimadas socialmente para esse fim. O constante acúmulo de capital de uma pequena parcela da população, em detrimento da expropriação de muitos gera a necessidade do Estado promover a proteção da propriedade privada. Para que ocorresse o acúmulo de capital para alguns, muitos necessariamente foram expropriados.

As possibilidades apresentadas pelo sistema capitalista de produção não proporciona a todos os homens a participação na divisão dos lucros do trabalho social, deixando grande parte da população excluída das conquistas provenientes do desenvolvimento da tecnologia, da aquisição de conhecimento, das novas alternativas de lazer e conforto.

\footnotetext{
${ }^{16}$ Criminalizar - Tornar criminal. / Criminal - que diz respeito a crime./ Crime - Violação dolosa ou culposa da lei penal. Violação das regras que a sociedade considera indispensáveis à sua existência. Infração moral grave. Delito. In Michaelis: moderno dicionário da língua portuguesa. São Paulo. Companhia Melhoramentos. 1998. Dicionário.

${ }^{17}$ Chaú́, M. Brasil: mito fundador e sociedade autoritária. São Paulo: Fundação Perseu Abramo. 2000 .
} 
[...] a expropriação e o acúmulo de riqueza não resultaram simplesmente em novas propriedades nem levaram a uma nova redistribuição da riqueza, mas realimentaram o processo para gerar mais expropriação, maior produtividade e mais apropriações (...) o processo de acúmulo de riqueza, tal como o conhecemos, estimulado pelo processo vital e, por sua vez, estimulando a vida humana, é possível somente se o mundo e a própria mundanidade do homem forem sacrificadas. (ARENDT. 1997.p. 267-268)

Esse processo excludente faz parte da própria lógica do sistema capitalista que exclui para incluir de outra forma: a inclusão precária e marginal pelo consumo. As pessoas podem estar excluídas e incluídas ao mesmo tempo. Podem estar integradas do ponto de vista da igualdade jurídica e formal garantida pela sociedade livre, mas ao mesmo tempo, podem estar excluídas socialmente e integradas economicamente na reprodução ampliada do capital - vendendo sua força de trabalho e consumindo mercadorias.

"Portanto, contraditoriamente situadas em face das possibilidades de participação plena nos meios de afirmação da sociedade contemporânea, como o mercado, o consumo e a propriedade." (MARTINS. 2003b. p.16)

A condição de trabalhador subordinado ao capital encerra contradições:

O trabalho do operário é social, mas o produto do seu trabalho é privado. A divisão dos resultados é desigual e injusta. A possibilidade de superação dessa contradição, com emancipação e humanização de todos está posta na relação capital-trabalho.

Outra contradição que fica escondida na relação do trabalhador com o capitalista é o fato de que aquele produz mais do que recebe por seu trabalho. $\mathrm{O}$ valor que ultrapassa o necessário para o operário sobreviver fica de posse de quem explora o seu trabalho e é dono dos meios de produção.

Essa contradição está latente na consciência do operário, mesmo que ele não se dê conta. Mas em momentos de crise na reprodução dessas relações sociais coisificadas - desemprego, baixos salários - a contradição aflora e torna difícil acreditar na concretização de sonhos prometidos por essa sociedade, e na ilusão de igualdade proposta pela economia capitalista, que esconde as contradições e injustiças próprias do seu funcionamento. Ou seja, a 
ruptura com o capital pode encerrar a possibilidade de superação dessa alienação da relação entre capital e trabalho em que vive o operário/trabalhador.

A lógica do capital obriga as pessoas a se subordinarem a ela, o que faz com que suas relações pessoais sejam mediatizadas por mercadorias, tornamse relações entre coisas. As relações coisificadas entre as pessoas concretiza-se em relações esporádicas, permeadas e mantidas por interesses. O trabalhador se desumaniza nessa socialização. Essas relações impedem a plena constituição do humano.

Há a necessidade de que o trabalhador não perceba a contradição, ou seja, um auto-engano é necessariamente mantido na relação que ele estabelece entre o capital e o trabalho. O auto-engano é constitutivo da relação social. Ele é mantido por mecanismos culturais e ideológicos de ilusão igualitária nas relações de trabalho.

Torna-se necessário acreditar na igualdade jurídica e liberdade propostas pela sociedade capitalista, ou seja, a de que o trabalhador pode escolher para quem vender a sua força de trabalho.

Essa igualdade e liberdade escondem a relação desigual, escondem a apropriação da mais-valia por parte do capitalista. A alienação é necessária para manter a reprodução das relações sociais na economia capitalista. $\mathrm{O}$ autoengano se recria cotidianamente e ideologicamente para que o trabalhador não entre em conflito consciente com a sociabilidade das relações de trabalho.

A contradição encerrada na produção social do trabalho, com a apropriação privada das riquezas provenientes desse trabalho - asseguradas pela igualdade jurídica e executadas na desigualdade econômica - permite a possibilidade de superação dessa situação.

O trabalhador pode tentar superar essa contradição de modo alienado, sem questionar de fato a contradição em que vive e se reproduz. Nesse caso, ele tenta apoderar-se das riquezas distribuídas desigualmente - busca na ascensão social uma saída individual. 
Mas a contradição em que vive o trabalhador é uma contradição social, para se libertar ele precisa ter uma ação coletiva, precisa libertar a sociedade inteira. Sua ação, nesse caso, torna-se uma ação de classe, inovadora. Essa é uma possibilidade histórica. É a possibilidade de libertação do humano na sociedade das relações coisificadas.

Para se libertar o ser humano precisa entrar em contato com outros seres humanos, sem a mediação das coisas e dos interesses. Precisa buscar espaços de participação coletiva, de encontro com outro humano.

As pessoas que vivem o processo de exclusão tentam modificar sua condição com estratégias de sobrevivência que os mantém na mesma condição de exclusão e inclusão precárias. Os bicos, trambiques, trabalhos informais e até as infrações penais são maneiras que a população tem encontrado para garantir alguma renda e sobrevivência. Os jovens entrevistados falam da entrada no mundo infracional pela falta de emprego como pode ser visto no trecho a seguir.

Eu acho isso... eu acho que precisa....precisa assim ter... ter uma reganância forte e ter uma prioridade também, um futuro... que nem... a maioria não consegue emprego, a maioria rouba porque não consegue emprego, daí... precisa alimentar a família, não consegue emprego, não consegue aquilo, que que eles vão fazer? Aí.. todo mundo fala, aqui não tem trabalho pra menor, ou... tipo... não tem trabalho pra quem não estudou... tipo isso, entendeu? As pessoas vão acatando isso, vão acatando isso... e começam a se envolver com as pessoas que... sabe? Trabalha na boca... . começa a vender droga, começa a passar droga, começa a ... fazer uma fitinha aqui, começa a fazer uma fitinha ali, então quando você vai ver você já está totalmente envolvido, entendeu?(Lucas)

[...] uma coisa, vamos se dizer, te obriga, você olha ali, você, você procura arrumar um serviço, uma coisa, mas você não consegue, por causa que.... hoje em dia, se você tiver idade demais você não arruma mais serviço e se você tem a idade, pede a experiência, como você? Você acaba de fazer um curso disso, mas como que você vai ter um ano de experiência e carteira assinada, sendo que ninguém te dá uma oportunidade, então o que acontece, daí você olha ali, você vê um cara ali que tava roubando, vendendo droga e sempre com dinheiro, sempre com .... (Douglas)

No depoimento do Lucas foi possível perceber também sua indignação com um amigo que começa a roubar mesmo tendo trabalho. O rapaz de 18 anos não tinha nenhuma passagem pela Febem e trabalhava na Vega Sopave, 
uma prestadora de serviços de coleta de lixo. Quais as possibilidades que esse jovem tinha diante de um emprego que explora sua força física ao extremo, não garante renda para sobrevivência do corpo, muito menos proporciona meios de ele questionar a expropriação sofrida? A saída encontrada por ele foi individual.

Chega nesse limite... que nem esse meu parceiro que eu estava falando que... ele, a mãe dele e ele deu uma força pra mim, pra mim passar o final de semana lá, ele... tipo... ele não tinha passagem nem nada, ele trabalhava na Vega, tudo... e ele tipo, sabe? Foi um menino sossegado... aí conforme foi passando esses tempos, ele começou a ter uma amizade diferente lá, entendeu? Começou a ter uma amizade diferente, aí mesmo trabalhando ele começava a roubar, com 18 anos!

(...)

[O que você acha que fez ele sair dessa onda, L.? Você contribuiu?] Ah... eu acho que... eu contribuí numa parte, mas quem contribuiu mesmo foi ele, foi ele mesmo, como foi eu mesmo que me contribuí, senão não tinha jeito mesmo... então o que que aconteceu? Ele teve que passar, ele teve que passar duas vezes pela cadeia pra ele vê? Entendeu? Acho que a primeira não foi suficiente, teve que passar a segunda.... e.... acho que a perda da mãe dele foi fatal pra ele, mexeu.... e agora ele está aí....

(Lucas)

O excluído tenta se incluir nessa sociedade, não tenta transformá-la. Os mecanismos sociais impedem a consciência do sistema de forças nas quais todos estão inseridos. Mantém os indivíduos afastados das possibilidades de participação plena e transformação social.

Esse desenvolvimento anômalo não se manifesta apenas nas privações que produz e dissemina. Manifesta-se, também nas estratégias de sobrevivência por meio das quais os pobres teimam em fazer parte daquilo que não os quer senão como vítimas e beneficiários residuais de suas possibilidades. (...) Nessas estratégias nem sempre compatíveis com o bem comum, no recurso ao ilegal e ao anti-social por parte das vítimas, a sociedade inteira é alcançada e comprometida nas compreensíveis ações de sobrevivência daqueles aos quais ela não oferece a apropriada alternativa de vida. (MARTINS. 2003b. p. 10-11)

Para que o Brasil se tornasse um país competitivo no mercado globalizado os processos de industrialização e desenvolvimento foram 
realizados à custa de planos e projetos econômicos, políticos e militares que levaram à míngua grande parcela da população brasileira.

O êxodo das pessoas das áreas rurais para a cidade, pois o plantio de grãos para exportação mecanizou o campo e expulsou trabalhadores para as periferias dos grandes centros; a terceirização de mão-de-obra para baratear custos de produção e o aumento do exército de reserva tornaram precárias as relações de trabalho.

As políticas econômicas promoveram a inclusão precária e marginal de uma considerável parcela da população. Esse grupo de pessoas, entre elas grande parte das famílias dos adolescentes que cometeram ato infracional, são incluídas apenas em termos do que é necessário para manterem-se reproduzindo como força de trabalho e consumo no sistema capitalista de produção, sem modificação da situação, sem que reivindiquem ou protestem pelas injustiças que sofrem.

A partir da década de 90 o trabalhador passou a demorar mais tempo para entrar novamente na lógica ampliada do capital como força de trabalho. Mas de acordo com as possibilidades advindas da criatividade das estratégias de sobrevivência, consegue manter-se como consumidor. Na verdade, um consumidor daquilo que sobra, do resto, das mercadorias com pequenos defeitos, das prestações infindáveis e com juros altos nas lojas de departamentos, dos leilões de imóveis credores etc.

O desenvolvimento social não acompanhou o desenvolvimento da tecnologia e das possibilidades advindas pelo desenvolvimento do capital. A força de luta foi abafada pela repressão explícita, pela inclusão ideológica, pela força da indústria cultural.

A sociedade capitalista produziu tecnologia e riquezas suficientes para que toda a humanidade pudesse usufruir desse avanço, porém, uma grande parte das pessoas está incluída no processo de produção da riqueza, mas não da sua distribuição. 
Em suas conseqüências sociais adversas, o modelo de desenvolvimento econômico que se firmou no mundo contemporâneo leva simultaneamente a extremos de progresso tecnológico e de bem-estar para setores limitados da sociedade e a extremos de privação, de pobreza e marginalização social para outros setores da população. (MARTINS. 2003b. p.13)

Essa exclusão, com conseqüente inclusão precária é inerente ao sistema capitalista de produção da forma como está hoje.

A miséria e a pobreza material impediram as pessoas da proteção da família e da propriedade. A família não protege porque todos os seus membros, espoliados pelas condições de trabalho, ou falta dele, não conseguem dar apoio e orientação aos mais jovens.

como você não é criado pelos pais, você sempre tem uma festividade na escola, dia dos pais... (...) e não tinha pra quem dar, via as crianças abraçando tudo ali e você ficava assim mal... que você ficava sentido, porque você não tinha ninguém ali pra você está comemorando junto, a única pessoa era a minha mãe, minha mãe trabalhava muito como funcionária pública, daí o que acontece, em...

(...)

É... talvez eu não teria.... acontecido tudo o que aconteceu comigo hoje em dia, que nem hoje em dia eu sento com as minhas sobrinhas, tudo, converso com elas, tem as minhas sobrinhas que tem, a mais velha tem 15, converso com elas tudo, explico o que é.... o que é camisinha, o que é relação.... eu faço isso porque minha cunhada não tem aquela coragem, meu irmão trabalha muito e de vez em quando chega e bebe, né? Daí já chega, toma banho, deita e dorme pra ir trabalhar no outro dia. Meu outro irmão mais velho só.... Deus que guarda ele, né? Que é viciado, é viciado também ele.... (Douglas)

A proteção da propriedade não acontece porque os trabalhadores pobres não conseguem obter recursos para a compra de uma casa que sirva como descanso para o corpo e abrigo para a memória da família.

A pseudoformação oferecida nas escolas, nos centros culturais, nos meios de comunicação é aquela que impossibilita o sujeito de pensar o real de forma distinta da que lhe é mostrada.

O pseudoformado (ADORNO. 1996) é aquele que está adaptado à sociedade e não questiona, possui uma formação com fim em si mesma, é aquele que precisa mostrar que sabe tudo e pode discorrer sobre qualquer 
assunto, mas na verdade não conhece nada ou o faz apenas superficialmente, ele despreza a cultura e não reconhece sua importância. Esse indivíduo perde a capacidade de crítica, de ironia, está sempre de acordo com o que se espera dele e com o que ele aprendeu que deve ser.

Os adolescentes pobres são ignorados pelas pessoas, são "vistos" apenas quando cometem uma infração, sobem nos telhados das Febem(s), estampam a contradição da sociedade de forma a não ser possível ignorá-los. Nesses casos são tidos como bandidos, perigosos, precisam ser banidos do contato social. Mas foi literalmente a falta de contato com o humano no outro que provocou tudo isso.

O desejo dos adolescentes pobres da periferia de uma grande cidade como São Paulo demonstra semelhança com o desejo dos jovens ricos. Como afirma José de Souza Martins:

[...] O estamento dos excluídos reproduz, degradadas, as formas próprias, conspícuas, do outro estamento; o tênis de qualidade inferior do adolescente pobre reproduz o tênis sofisticado do adolescente rico. Faz do mundo do excluído um mundo mimético, de formas que ganham vida no lugar da substância. É o mundo do imaginário, da consciência fantasiosa e manipulável. (MARTINS. 2003a. p. 36)

Esse mundo sonhado pelos adolescentes pobres é o mundo apresentado pela indústria cultural nos cinemas, na televisão, nas escolas, em jornais e revistas.

A indústria cultural produz bens dizendo que são fundamentais para as pessoas que por seu lado, acreditam na real necessidade delas. A indústria produz o desejo e o transforma em necessidade. "A atitude do público que, pretensamente e de fato, favorece o sistema da indústria cultural é uma parte integrante do sistema, não sua desculpa." (HORKHEIMER e ADORNO. 1985. p. 115)

Todos são bombardeados com informações e produtos de consumo que dizem o que devem vestir, comer e sentir. Aquele que não segue essa "orientação" é discriminado, desvalorizado e humilhado. O trabalho, os 
estudos e as relações pessoais são impregnados dessas informações: o trabalho é alienante, a educação oferecida é incompleta, as relações são superficiais e efêmeras.

Ah, tipo assim, você.... você é um adolescente, você vê seus amigos de roupas novas, você vê seus amigos de moto, tendo dinheiro pra sair com namoradas, esses negócios, e você... e você sempre quando você tem, se vai num lugar, se você tem uma calça você não tem um tênis, então você vai num lugar você é tirado sarro, os próprios amigos, às vezes até primo, parentes também que tem alguma coisa e não ajudam, então o que acontece, você pede uma ajuda pra uma pessoa pra você não entrar e às vezes por conseqüências da vida, você acaba entrando nessa, nessa vida, não...(Douglas)

Esses mecanismos ensinam que o valor de uma pessoa está nos objetos que pode adquirir. Objetos que transcendem a necessidade, objetos que tornam o ser humano refém de sua necessidade. Objeto que traz humanidade ao mesmo tempo em que desumaniza.

Alguns entram na criminalidade para conseguirem os objetos do desejo, outros lutam por terminar os estudos, conseguir o primeiro emprego, cursar uma faculdade privada.

Todos eles, os ricos e os pobres, os que estão dentro e os que estão fora da ordem moral estabelecida estão rendidos à estrutura social dominante e aos ditames da indústria cultural e da massificação.

Então você não consegue, pela discriminação, a qual, hoje em dia, tem muitas pessoas que estão entrando na marginalidade ou continuam por falta de oportunidades... (Douglas)

A nova forma de desigualdade produz a sensação de igualdade no plano ideológico, mas não no plano material. A casa dos pobres, conseguida com um enorme sacrifício, leva-os a condição de humanos, viram "gente" perante outras "gentes".

Peguei esse dinheiro aí que eu tava e eu tinha uma moto e eu tenho um Chevete também, né? O carro, aí eu peguei e falei: não, vou vender minha moto, tipo eu tava devendo nas Casas Bahia, eu vou vender minha moto, quito as Casas Bahia e aí eu vejo o que dá pra mim tirar, né? Aí eu peguei esse dinheirinho e comprei um terreno lá pra mim construir minha 
casa, eu e minha esposa, entendeu? Aí eu falei, a gente tem que ter o nosso lugar, a gente pegou, construiu nossa casa lá, tudo e tirou os móveis nas Casas Bahia e aí tipo... (Lucas)

O adolescente pobre sabe que ele é considerado cidadão de segunda categoria, que para ele a justiça não auxilia, pelo contrário, pune. É isso que ele vive no dia-a-dia das batidas policiais dos ônibus que circulam na periferia, no travamento das portas "automáticas" dos bancos, no desrespeito sofrido dentro de uma unidade de internação da Febem de São Paulo. O direito de todos vira o privilégio de alguns.

eu acho que eu já estava com tanto... ódio assim de, de não ser preso... de, ódio de policial porque também na... nas ruas aonde que a gente ficava, a gente sempre era o mesmo grupo e aí... eles tinha meio que medo assim, porque quando a gente era... era abordado por eles, eles batiam e diziam que uma hora ou outra eles iam pegar e iam matar a gente.. não sei porque, acho que era porque, quando estava aquele mesmo grupo, aquele mesmo grupo fumando maconha, as pessoas que eram da região ali.. falavam pra eles... ligavam... denunciavam e ali eles vinham e via que era a gente que estava fumando maconha... [Eles batiam?]. Se batiam? Nossa! muito... (Alex)

A igualdade dessa sociedade está na relação de trabalho livre, em oposição à relação de trabalho escravo. Mas há uma contradição a ser observada: os trabalhadores estão livres socialmente, pois não dependem de ninguém para terem o poder sobre sua força de trabalho, mas são dependentes economicamente, pois não têm os meios de produção e não estão em condições de escolher para quem querem vender sua força de trabalho. No momento há mais gente querendo vender sua força de trabalho do que donos do capital e dos meios de produção querendo comprá-la.

A procura por qualquer emprego é premente:

Não está tendo freela, não está tendo essas coisas, então eu tô procurando vários empregos, entendeu? Porque eu não quero, eu não procuro ter aquele pensamento, pô tô precisando eu vou roubar, roubar sabe? Por que eu sei que hoje eu tenho 22 anos, já... eu sei que, se eu for preso, ninguém, ninguém vai... depois... é... tipo, eu não vou conseguir recuperar minha vida, entendeu? Mesmo... eu tendo minha casa, eu tendo minhas coisas eu não vou conseguir voltar pra... que isso daí vai me prejudicar, então meu pensamento é o quê? É eu conseguir fazer alguma 
coisa, entendeu? É eu chegar e... bom.. vamos... o que que tem pra mim fazer, sabe? E qual o trabalho que tem? Se não tiver nada na parte que eu gosto de câmera... alguma coisa, qualquer trabalho, entendeu? (Lucas)

Quando não se pode conseguir um trabalho, a possibilidade que se apresenta pode ser a entrada na criminalidade:

que nem... a maioria não consegue emprego, a maioria rouba porque não consegue emprego, daí... precisa alimentar a família, não consegue emprego, não consegue aquilo, que que eles vão fazer? Aí.. todo mundo fala, aqui não tem trabalho pra menor, ou... tipo... não tem trabalho pra quem não estudou... tipo isso, entendeu? As pessoas vão acatando isso, vão acatando isso... e começam a se envolver com as pessoas que... sabe? Trabalha na boca... . começa a vender droga, começa a passar droga, começa a ... fazer uma fitinha aqui, começa a fazer uma fitinha ali, então quando você vai ver você já está totalmente envolvido, entendeu? Então eu acho assim... (Lucas)

Hoje em dia tem muitos jovens, muitas pessoas assim que vão, né? Pro mundo do crime por causa da precisão, porque precisam... [De comer ou precisa de roupas, essas coisas?] De comer, de roupa, de dinheiro pra poder se manter, né?(Douglas)

Os jovens falam da necessidade de emprego ou trabalho para garantir o consumo. Consumo esse estimulado pela mídia, pela escola, pelos amigos. Mas como reagir frente a falta concreta de possibilidade de obtenção de renda?

No livro "A Miséria do Mundo" há um trecho em que os autores falam sobre a problemática da moradia e da vida dos jovens nos guetos americanos. Longe de fazer uma comparação entre a realidade das periferias paulistanas e os guetos de Los Angeles, não há como deixar de perceber algumas coincidências nas falas dos entrevistados. Em certo momento, há o seguinte comentário:

A troco de que escolher a via legit quando as recompensas que decorrentes são tão magras e quase tão aleatórias que, tangíveis e imediatas, mesmo que sejam de alto risco, prometidas pela economia de rua que, além de um campo de onde ostentar os valores de honra viris que formam a base da cultura pública do gueto, oferece, se não a realidade, pelo menos a ilusão de ser patrão de si mesmo, e por isso a possibilidade de escapar à humilhação e à discriminação que são o destino quotidiano dos que aceitam os slave jobs da nova economia de serviços. [...] (BOURDEIU. 1999. p. 188) 
Juridicamente, operário e capitalista são iguais, mas nessa igualdade está a sua subordinação. A vontade de um não está subordinada a vontade do outro. Há um juiz que deve decidir com imparcialidade. A subordinação está no fato de que o trabalhador é obrigado a vender sua força de trabalho ao capitalista para poder sobreviver. Além disso, o capitalista compra mais que o trabalho necessário para que o trabalhador sobreviva, o capitalista compra trabalho excedente, compra mais-valia. Mas paga, em forma de salário, apenas o valor que o trabalhador precisa para se manter como força de trabalho e se reproduzir para criar nova força de trabalho para o futuro. O capitalista retém o valor excedente em forma de meios de produção, de renda, de mercadorias.

Em épocas atrás havia um maior poder de barganha da classe trabalhadora para discutir com o dono do capital e reivindicar melhores salários, mas hoje, com a falta de emprego, esse poder de luta diminuiu e a luta pelo emprego passou a ser fundamental nas lutas entre trabalhadores e capitalistas.

Veja a fala de um dos adolescentes que foi demitido por preconceito e ficou com receio de correr atrás dos seus direitos de trabalhador.

[...] aí eu peguei e falei: não, tranqüilo, aí eu fui, recebi meus benefícios, tudo.... o pessoal do sindicato também falou pra colocar no pau, mas aí o que que acontece? Se eu colocasse no pau, e depois, se eu quisesse entrar em outra emissora? Como que ali é uma rede de televisão, eles conhecem tudo, entendeu? Iam falar "ah não, ele colocou a gente no pau, então não vamos aceitar ele, né?” (Lucas)

Do ponto de vista da sociedade capitalista o trabalhador é um indivíduo porque sua liberdade pessoal e seus direitos pessoais não podem ser eliminados. O trabalho individual do operário é produtor de trabalho social e de riqueza social.

A força de trabalho do trabalhador é mercadoria que ele vende ao capitalista, independente da mercadoria concreta que produz. No mundo do operário, seu trabalho é separado do produto (mercadoria) do trabalho. O valor de um e de outro são obtidos não através da conversão do tempo 
empregado para a produção, mas de acordo com a produção de mais-valia e através da lógica do mercado.

A luta da classe operária, no Brasil, tem sido uma luta por diminuição da exploração, não por superação da contradição da sociedade capitalista. E, no início do século XXI já não é uma luta por melhores salários e condições de trabalho, é uma luta por emprego. É uma luta “(...) pela preservação do capital e pela preservação das relações capitalistas." (MARTINS. 2003b. p.88). Não é uma luta contra o capitalismo.

A relação de exploração da sociedade capitalista está chegando a extremos, como será a sua superação?

Há processos sociais excludentes, mas não há exclusões consumadas, definitivas, irremediáveis. Uma sociedade cujo núcleo é a acumulação de capital e cuja contrapartida é a privação social e cultural tende a empurrar "para fora", a excluir, mas ao mesmo tempo o faz para incluir ainda que de forma degradada, ainda que em condições sociais adversas. O "excluído" é, na melhor das hipóteses, a vivência pessoal de um momento transitório, fugaz ou demorado, de exclusão-integração, de "sair" e "reentrar" no processo de reprodução social. E sair de um jeito e reentrar de outro, pois a sociedade contemporânea é uma sociedade que pede contínua ressocialização de seus membros, contínua reelaboração das identidades. (MARTINS. 2003b. p.46).

A sociedade capitalista atual propõe um acordo fundamental: o respeito à propriedade privada. Partilhar essa premissa torna-se o sustentáculo da construção da dignidade pessoal e da ordem social. Violar esse direito produz reações nos mecanismos institucionais para controle dos atos humanos.

Há uma promessa implicada nessa lei, que é ensinada nos espaços de socialização (família, escola, igrejas etc), a de que haverá uma recompensa para aqueles que se sujeitarem a lógica do capital e ao mercado de trabalho.

Para a maioria da população que não possui os meios de produção e está obrigada a vender sua força de trabalho por valores que são suficientes apenas para a reprodução física da força pessoal, qual será essa recompensa? A dignidade humana? Parece que não. 
As estatísticas sobre a qualidade de vida da população, medidas através do IDH - Índice de Desenvolvimento Humano, indicam que a qualidade de vida do brasileiro nos grandes centros urbanos é bem precária. O Relatório de Desenvolvimento Humano das Nações Unidas relata que o IDH brasileiro cresceu: passou de 0,788 em 2003 para 0,792 em 2004, resultado que mantém o país entre as 83 nações de médio desenvolvimento humano ${ }^{18}$. No entanto, há fortes diferenças regionais na qualidade de vida da população. Na grande São Paulo, o IDH-M (municipal) em 2000 era de 0,828. Apesar do índice da grande São Paulo ser superior ao do Brasil, tem-se que levar em conta as desigualdades dentro do próprio município.

Pelos dados apresentados no capítulo Os adolescentes julgados autores de atos infracionais vê-se que a realidade das famílias dos adolescentes que foram julgados autores de atos infracionais está longe de ser digna e ideal. Os trabalhos pouco especializados; a baixa escolaridade dos pais, e mesmo dos jovens; as condições de moradia e renda etc, mostram que eles estão bem abaixo do que poderia ser considerado uma vida humana confortável.

Quando trabalhei na Associação Novolhar conheci Roberto. O adolescente chegou para o curso de Vídeo e Produção com 17 anos. Estava cumprindo uma medida socioeducativa de liberdade assistida. Quando foi apreendido pela polícia, frequentava escola e vivia com a namorada e um filho na periferia da zona sul de São Paulo. O pai era Pastor de igreja evangélica e a mãe dona de casa. Seus pais responsabilizaram-se por ele perante o poder judiciário quando foram comunicados pela justiça que o rapaz tinha sido apreendido por cometer um ato infracional.

Roberto freqüentou o curso poucos meses. Comentava a necessidade de arrumar trabalho para sustentar a mulher e o filho. Certo dia telefonou

\footnotetext{
${ }^{18}$ O IDH foi criado para medir o nível de desenvolvimento humano dos países a partir de indicadores de educação (alfabetização e taxa de matrícula), longevidade (expectativa de vida ao nascer) e renda (PIB per capita). Seus valores variam de 0 (nenhum desenvolvimento humano) a 1 (desenvolvimento humano total). Países com IDH até 0,499 são considerados de desenvolvimento humano baixo; com índices entre 0,500 e 0,799 são considerados de desenvolvimento humano médio; e com índices maiores que 0,800 são considerados de desenvolvimento humano alto. www.pnud.org.br, acessado em 03/10/2007.
} 
avisando que havia arrumado um trabalho de segurança na 'Loja de Um Real'. Pediu desculpas por ter se comprometido a fazer o curso até o final e estar abandonando no meio.

Quase um ano depois, voltou a nos procurar para conversar.... Contou que quando estava na vida do crime tinha dinheiro para sustentar a família, tinha prestígio no bairro, agora (mostrou a carteira de trabalho registrada) tinha emprego fixo, ganhava um salário mínimo, sentia-se humilhado por depender do pai para pagar o aluguel e comprar comida para o filho. Não tinha mais a consideração dos outros.

O trabalho aviltante que explora em demasia a força do trabalhador e que serve, quando muito para simples subsistência e sobrevivência de sua família, perde o caráter de atividade em que a humanidade se realiza. Sem saber, Roberto reclamava da sua humanidade perdida....

Estar na criminalidade leva as pessoas a serem valorizadas pelos membros da sua comunidade. Essa consideração obtida pela via do crime não é a valorização daquele que considera o outro pelas suas idéias, que permite um modelo positivo para o jovem em formação.

A valorização pessoal pelo 'poder' adquirido com a vida do crime impõe aos indivíduos a não possibilidade de humanização. Tanto para aquele que acha que está com o poder, quanto para os que apenas o almejam.

E também hoje em dia tem muitos jovens, adolescentes, que vão pelos outros... "ah aquele ali é bandidão, aquele ali já tirou tantos dias na cadeia, aquele tem uma biqueira ali, é isso assim, assim, assim, né"? Então o que acontece? Eu vou andar do lado dele.... então pra você andar do lado dele... pra se sentir... como se fosse uma pessoa da mídia, então falam isso pra molecada... "ah, eu ando com tal irmão assim, assim, assim, ah eu faço umas corridas ali também, que não sei que..." [Isso valoriza as pessoas?] $E$, pra eles! Pra mim não valoriza ninguém, mas pra muitas pessoas.... é mais no meio da juventude, da molecada, é pra eles "nossa, você anda com tal!" Então pra muitos é até vangloriando, é como se fosse um deus.... (Douglas)

Segundo Douglas, os jovens da periferia querem ser como os "bandidões" pelo status que possuem e dessa forma seriam valorizados como são as pessoas da mídia. Nota-se que o interessante é ser visto: como 
'bandido' ou como 'mocinho'. Aparenta existir apenas essas duas possibilidades, mas afinal, são esses os modelos divulgados a exaustão pelos meios de comunicação.

$\mathrm{Na}$ nossa sociedade, as pessoas podem viver na pobreza quase absoluta e isso é tolerável pelo acordo social - mas não podem pegar o que não lhes pertencem - atitude que é condenável por todos. É o respeito pela propriedade privada sendo mais valorizado que o respeito a uma vida digna.

A aquisição de mercadorias e serviços é fundamental para o desenvolvimento do sistema capitalista de produção. A circulação do capital é a força motriz das engrenagens de produção, circulação e venda de produtos. Para que a máquina não pare, o consumo é incentivado por todos os meios possíveis. Passa a ser valorizado socialmente aquele que possui renda para consumir.

Hanna Arendt (1997) afirma que o valor de um produto é adquirido quando o objeto aparece na esfera pública e torna-se mercadoria. $\mathrm{O}$ valor independe da quantidade de trabalho ou labor necessário à sua produção. Também não é levado em consideração o capital investido, o lucro obtido ou o material utilizado na confecção do objeto “[...] mas [depende] única e exclusivamente [d]a esfera pública, na qual o objeto surge para ser estimado, exigido ou desdenhado. $\mathrm{O}$ valor é aquela qualidade que nenhuma coisa pode ter na privatividade, mas que todas adquirem automaticamente assim que surgem em público." (ARENDT. 1997.p.177) As coisas passam a ter valor na comparação com outras coisas. O valor é mutável e independe da vontade do homem.

Na sociedade atual estabelece-se uma relação entre o valor de alguém e o valor do objeto que possui, ou seja, da sua possibilidade de compra. "[...] tem valor quem sempre pode ter objetos valorizados, [...] nesta relação entre sujeito e objeto, o valor está primordialmente relacionado ao objeto, que, em relação com outros objetos, tem seu valor relativizado e transferido ao sujeito [...]" (ROMAN, 2007. p. 6) 
A pessoa pode ser valorizada ou desvalorizada por sua aparência física, de acordo com as roupas que usa, com um corte de cabelo específico, pelo bairro em que mora, pela construção de sua casa, pelos alimentos que consome etc. O sentimento pessoal pode ser de sucesso e poder, se tiver objetos valorizados; ou de fracasso, caso não possa obtê-los. Esses sentimentos mobilizam o sujeito para a necessidade de obter renda: através do mercado de trabalho ou cometendo infrações.

Eu acho que quando a gente arrumava briga, a gente sempre era o mesmo grupo e ninguém mexia com a gente, quando mexia com um mexia com todos, então quando a gente pegava pra bater era todos contra aquele e era uma covardia tremenda, mas a gente achava engraçado, achava bom e acho que era por isso... (Alex)

mas a gente sempre assaltava o mesmo grupo, como parceiros, amigos de escola viraram parceiros, que já não ia pra escola, já não queria mais saber de nada só queria saber de dinheiro, de assalto.... de viver no meio da malandragem e de sentir que as pessoas tinham medo, algumas pessoas tinham medo da gente. Isso a gente se sentia bem com isso, porque.... era uma forma de criar um certo respeito..., criar um certo respeito no meio da... da comunidade, no meio da malandragem, a gente tinha um certo respeito, porque a gente já, desde pequeno, desde os 15 anos a gente já tava começando a roubar, assaltar e... a gente fez isso sozinhos, sozinhos que eu digo, não precisou de ninguém que já estava no meio do crime pra gente poder começar a assaltar. (Alex)

O jovem busca reconhecimento social para se perceber como sujeito distinto de outros, busca visibilidade. E a busca da identidade masculina, na sociedade brasileira está na força física, na virilidade, na "esperteza", em ser homem.

[...] a gente ia começar a brincadeira de roubar os outros pra gente não depender mais da... dos nossos pais... porque... eu acho que todos tinham... o mesmo... a mesma cabeça... de que.... por mais que a nossa família tivesse assim... passando uma necessidade, a gente já tava com a cabeça assim... que a gente tinha que ser homem, homem é... pra poder já sustentar a família, mas não querer trabalhar, porque na época era só diversão, né (....)aí a gente foi contar as moedas, não lembro quanto tinha, mas foi muito pouco e a gente ficou super feliz assim de ter o nosso próprio dinheiro, sem precisar que nossos pais dessem.... dessem esse dinheiro pra gente.... (Alex) 
Esses jovens estão criticando e afirmando a sociedade da qual são produto: se o grupo de jovens pode mostrar o descontentamento com a situação de exclusão vivida por eles, os seus atos reafirmam os valores da sociedade que criticam - sentirem-se reconhecidos, terem bens materiais etc.

Os jovens entrevistados mostram como os adolescentes querem ter objetos para sentirem-se pertencentes a um grupo. Os adolescentes querem se sentir importantes, dominar à força na impossibilidade de ter de outra maneira.

aí chegou o tempo que eu queria tênis, queria roupa, queria aquilo, sabe, ninguém me dava.... então eu comecei a .... roubar, comecei a roubar, aí eu comprei minha arma...(Lucas)

eu acho que é isso, a convivência e a necessidade e a vontade de... de assim, de ganância de ter o seu próprio dinheiro, assim, de ver algumas pessoas com carro, moto, com dinheiro fácil.... e você ter aquela ganância de, de ter pra você.... De ter coisas, essas coisas, da maneira mais fácil possível, mas... depois você cresce, amadurece, sabe... sabe que não é dessa maneira. (Alex)

Bom, deixa eu lembrar... A gente jogava uma bola, mas a gente era o grupo que os... que o pessoal da nossa idade tinha mais medo... e a gente jogava bola, e o pessoal jogava bola com medo da gente, assim... e isso era estranho, era estranho e ao mesmo tempo .... é... nós se sentíamos bem de tá, tá meio que dominando o espaço assim....

(...)

nisso a gente já tá em outro tempo, começamos a conviver com outras pessoas que assaltavam também, mas a gente sempre assaltava o mesmo grupo, como parceiros, amigos de escola viraram parceiros, que já não ia pra escola, já não queria mais saber de nada só queria saber de dinheiro, de assalto.... de viver no meio da malandragem e de sentir que as pessoas tinham medo, algumas pessoas tinham medo da gente.

[ Isso vocês sentiam como legal?]

Isso a gente se sentia bem com isso, porque.... era uma forma de criar um certo respeito..., criar um certo respeito no meio da... da comunidade, no meio da malandragem, a gente tinha um certo respeito... (Alex)

Os objetos são necessários para a proteção do corpo, para o deslocamento na cidade, para o conforto das pessoas. Os objetos carregam a história do trabalho e dos trabalhadores. O ser humano precisa desses objetos para que sua humanização ocorra. Mas o que esses jovens almejam são objetos fetichizados pelo poder que a eles será remetido caso possam adquiri-los. 
Aquele que consegue obter os objetos valorizados do momento - e esses mudam com uma velocidade impressionante! - sente-se valorizado e potente frente às outras pessoas. Sendo que, esses outros, também o valoram positivamente. Nessas circunstâncias, o ser humano só sente que possui poder quando está de posse de algo. Mas, contraditoriamente, ter posse de objetos que transformam o próprio sujeito em um deles, faz com que o sujeito fique, na verdade, em poder das coisas, desumanizando-se.

Esses objetos são apresentados pela indústria cultural e podem ser: roupas de grife, um carro do ano, a marca de um cigarro, enfim, uma série de mercadorias que conferem status. O status empodera o sujeito que passa a ser valorizado pelo grupo de pares e desejado por mulheres. "[...] o objeto é investido do poder de humanizar sujeitos objetificados. Para adquirir esse atributo valioso, a coisa é separada da rede de relações sociais que a produzem, tomando para si o que é constituído pela atividade humana." (ROMAN. 2007. p.71).

O desejo de sentir-se forte e poderoso movimenta o sujeito para a aquisição desses objetos fetichizados. O desejo de visibilidade do jovem o leva a obter esses objetos que ele julga garantirem sua aparição. $\mathrm{O}$ ato infracional pode levar o jovem a adquirir esses objetos, a invisibilidade perversa do adolescente pobre o leva a uma visibilidade também perversa. $\mathrm{O}$ objeto não o transforma em humano, mas o desumaniza cada vez mais.

“[...] No afã de ter tudo [...] sonho, poder, reconhecimento etc mergulham rumo aos riscos e perigos do desconhecido e se vêem enredados, de fato, pela alienação, pelo dinheiro e pela violência.” (SALES. 2004. p. 122)

Os objetos fetichizados perdem sua referência histórica e dependente do trabalho humano. Cada objeto carrega em si a história da humanidade e o trabalho humano necessário para a sua elaboração e construção.

$\mathrm{Na}$ sociedade capitalista, a mercadoria incorpora o trabalho humano abstrato em forma de valor, como se este fosse um de seus atributos naturais, apagando assim os traços que definem suas origens como produto das redes sociais de trabalho [...] Enquanto o valor de uma mercadoria passa a ser espelhado por outra, que 
"naturalmente" teria esse atributo, as relações sociais de trabalho são encobertas. [...] (ROMAN. 2007. p.8)

O valor, produto das relações humanas, é atribuído ao objeto, como se fosse da natureza dele, portanto, abstraindo-o da história humana que o produziu.

A mesma separação que ocorre na sociedade capitalista entre o dono dos meios de produção e o trabalhador, e que encobre a separação entre produtor e objeto produzido ocorre na separação do valor do objeto e do trabalho humano necessário para produção desse valor.

A relação de trabalho aviltante a que o operário está submetido aliena-o de sua humanidade, subordinando-o às necessidades de sobrevivência individual.

Todos os objetos, incluindo aí a comida necessária para a manutenção do corpo do trabalhador, são mercadorias com seu valor de uso e de troca. Todas carregam a história da humanidade ao mostrar, inclusive na sua ausência, que existe uma classe de expropriados historicamente constituídos pelo sistema capitalista de produção, onde os meios de produção estão nas mãos de poucas pessoas.

A sociedade capitalista valoriza a apropriação individual de recursos, tanto para a sobrevivência do sujeito como para sua ostentação. Há uma valorização da competição entre pessoas e grupos.

$\mathrm{O}$ adolescente que comete uma infração com a intenção de obter os objetos que foram imbuídos de valor humano, para sentir-se valorizado por outros e por si mesmo, age, sem saber, "como se incorporasse a nudez da espoliação capitalista: não é dono quem faz, mas quem usurpa." (ROMAN. 2007. p. 10).

Quando alguém rouba para comer há uma espécie de camaradagem, como se fosse tolerável pela sociedade a naturalidade da necessidade de comida. Porém, ao naturalizar e tolerar o acontecido, o processo histórico de existência de uma classe de expropriados que não pode conseguir, sequer, o mínimo necessário para sobrevivência da força de trabalho fica escondido. 
O processo sócio-histórico deve ser sempre investigado e explicitado no entendimento de fenômenos aparentemente individuais, porém historicamente constituídos.

Essa sociedade valoriza a realização das satisfações no "aqui e agora". As conseqüências não são medidas na busca desse desejo. Em uma cidade como São Paulo, parece que todos têm acesso às possibilidades e mercadorias oferecidas pelo desenvolvimento da tecnologia, porém essa possibilidade é aparente e está muito distante quando se vive na miséria das periferias da cidade, imersos na lógica excludente do capital que privilegia alguns em detrimento de muitos.

A indústria cultural afirma que todos devem ser iguais, devem ter necessidade de consumir os bens valorizados por uma indústria muito maior que a vontade individual desses jovens. O jovem Lucas disse em seu depoimento que "cada um vê com uma visão diferente", mas a visão diferente dele é trabalhar ou roubar, o destino do dinheiro adquirido é o consumo das mesmas mercadorias.

Os jovens buscam no consumo, no poder (virilidade, masculinidade), no valor atribuído a si pela obtenção de certas mercadorias e no dinheiro a busca por sua humanidade. Humanidade essa que, como será apresentado no próximo capítulo, não está disponível nas prateleiras.

A indústria cultural ensina a todos que as desigualdades, as incoerências, os valores morais, todo o mecanismo para manter as pessoas humilhadas, consumindo, são naturais. "A violência da sociedade industrial instalou-se nos homens de uma vez por todas. Os produtos da indústria cultural podem ter a certeza de que até mesmo os distraídos vão consumi-los alertamente." (HORKHEIMER e ADORNO. 1985. p.119) As informações são "oferecidas" em todos os momentos e situações: no trabalho e no descanso, nos noticiários e nas novelas da televisão, no cinema, na música etc.

Como foi visto na vida de Roberto, no exemplo citado acima, a sociedade valoriza o trabalhador honesto, a carteira assinada é um sonho, mas 
o salário mensal humilha. "Assim como os dominados sempre levaram mais a sério do que os dominadores a moral que deles recebiam, hoje em dia as massas logradas sucumbem mais facilmente ao mito do sucesso que os bemsucedidos." (HORKHEIMER e ADORNO. 1985. p.125.)

O trabalho que deve inserir na sociedade, inclui e expulsa do consumo, da dignidade, da possibilidade de tornar-se um indivíduo autônomo. Pois, frequentemente, os trabalhos oferecidos aos jovens são alienantes e não proporcionam o desenvolvimento da crítica e da autonomia.

A indústria cultural se baseia em dados estatísticos que classificam os consumidores em níveis de consumo e cada qual deve se comportar de acordo com o que é esperado para o seu nível. O indivíduo foi transformado em uma massa homogênea e sem possibilidade de escolha. Não há indivíduo e não há escolha. Não há tensão entre indivíduo e sociedade, um foi tomado pelo outro.

A industrialização com produção de bens de consumo que poderiam retirar o homem de atividades desumanas, a produção de produtos para o descanso e o lazer e a indústria da cultura e do entretenimento não tornaram o homem mais humano, como se dizia na promessa inicial. "A indústria cultural não cessa de lograr seus consumidores quanto ao que está continuamente a lhes prometer." (HORKHEIMER e ADORNO. 1985. p. 130)

A promessa de sucesso como o mocinho do cinema, a possibilidade de "ficar rico" como os cantores de música regional sertaneja, o fumante de certa marca de cigarro que vive rodeado de mulheres bonitas como mostra o comercial de televisão etc estão aí para todos. A indústria cultural engana a possibilidade de satisfação, mas a afirma como necessário.

A ideologia se esconde no cálculo da probabilidade (...) Só um pode tirar a sorte grande, só um pode se tornar célebre, e mesmo se todos têm a mesma probabilidade, esta é para cada um tão mínima que é melhor riscá-la de vez e regozijar-se com a felicidade do outro, que poderia ser ele próprio e que, no entanto, jamais é. (HORKHEIMER e ADORNO. 1985. p. 135- 136)

Ensinaram aos adolescentes que cometeram atos infracionais que todos são iguais e substituíveis. É isso que a indústria cultural propaga o tempo todo. 
Mas ensina também que o acaso pode levar você ao sucesso, não precisa se preocupar com nada, se tiver sorte, conseguirá.

A ideologia molda-se ao que é mais interessante em cada caso. Ninguém fica sem resposta. Apesar de parecer um discurso vago por adaptarse às várias situações, a ideologia não é menos potente, pelo contrário e por isso mesmo, torna-se cada vez mais o discurso da dominação. A perpetuação da sociedade desigual permanece.

As massas desmoralizadas por uma vida submetida à coerção do sistema, e cujo único sinal de civilização são comportamentos inculcados à força e deixando transparecer sempre sua fúria e rebeldia latentes, devem ser compelidas à ordem pelo espetáculo de uma vida inexorável e da conduta exemplar das pessoas concernidas. (HORKHEIMER e ADORNO. 1985. p.143)

A violência é uma resposta à transformação de todos em mercadorias, à pseudoformação oferecida, a esse mundo coisificado que precisa explicar tudo sem deixar possibilidade do indivíduo pensar e preencher espaços com criatividade e autonomia. Essa sociedade civilizada suscita a crueldade.

A desumanização implantada pelo processo capitalista de produção negou aos trabalhadores todos os pressupostos para a formação e, acima de tudo, o ócio. As tentativas pedagógicas de remediar a situação transformaram-se em caricaturas. Toda a chamada 'educação popular' (....) nutriu-se da ilusão de que a formação, por si mesma e isolada, poderia revogar a exclusão do proletariado, que sabemos ser uma realidade socialmente constituída. (ADORNO. 1996. p. 393)

Reformas pedagógicas não resolvem o problema da pseudoformação, uma vez que essa é uma questão social. O oferecimento de bens culturais, disponíveis a todos pela indústria cultural não favorece a formação do indivíduo. Sua apresentação como bem de consumo - mercadoria para formação, massificado e resumido, converte-o em pseudocultura e esta só favorece a psudoformação.

As informações em tempo real, proporcionadas pela imprensa e pela internet, também não auxiliam a formação do indivíduo. Elas isolam os 
acontecimentos, faltam conexões entre uma notícia e outra, o estilo de escrita, os textos curtos e superficiais não afetam a experiência do leitor. "Na substituição da antiga forma narrativa pela informação, e da informação pela sensação reflete-se a crescente atrofia da experiência." (BENJAMIN. 1989. p.107)

A educação não é transmitida aos alunos como experiência, pois os próprios professores, pseudoformados, não possuem o conhecimento como experiência, aquele que é incorporado e pode ser transmitido com empatia, coerência, graça. O mundo civilizado que pode proporcionar conhecimentos a todos não valoriza a experiência e a conseqüente formação do indivíduo crítico.

A instituição responsável pelos adolescentes que cometem ato infracional, durante o período de cumprimento da medida socioeducativa (Febem) faz questão de apagar essa possibilidade de consciência e resistência. Ocupa o espaço e o tempo dos internos com lições de moral, tudo está previsto e controlado, apaga-se a possibilidade da crítica. Domesticam-se corpos e mentes e junto com elas a possibilidade de rebeldia e questionamento. São considerados aptos a sair aqueles que passam a proferir o discurso da adaptação: "quero trabalhar, estudar e viver bem com a minha família, Senhora".

Nessa sociedade em que predominam a pseudoformação e os ataques da indústria cultural, o indivíduo, na verdade um encontro de universais genéricos, não é um indivíduo autônomo. É um sujeito que não pode ser ele mesmo, mas sim o que se diz que ele tem que ser. É assim que ele sente, é assim que ele é ensinado.

Essa sociedade também não valoriza o encontro entre as pessoas, com relações livres de interesses subentendidos. A sociedade atual carece de enraizamento: uma comunidade, uma casa, uma história pessoal, histórias que explicam os mistérios e o pertencimento a esse mundo. Um mundo de coisas e 
de gentes, onde as relações do humano com o humano e também do humano com o não humano são fundamentais.

Mas o sistema é contraditório, ao mesmo tempo em que produz o véu que encobre a realidade, também ensina, nas escolas, conteúdos que permitem a crítica à pseudoformação. Os indivíduos não são totalmente reduzidos pela indústria cultural e pela pseudoformação, há alguma possibilidade de resistência. O paradoxo da situação é que o véu produzido pela pseudoformação é frágil, mas não se consegue rompê-lo. Isso ocorre porque o mecanismo que veda a visão do real carrega elementos subjetivos/afetivos que fazem com que o indivíduo saiba como tem que ser, acreditando que é a sua vontade que faz ser como se é.

Uma volta ao passado não seria a maneira de mudar o curso da história da sociedade ocidental. Faz-se necessário uma crítica a pseudocultura, à luz do espírito do passado, mas sem que se volte a ele. 
Capítulo 7 - INFRAÇÃO - O ATO NA (IM)POSSIBILIDADE DA AÇÃO 


\section{INFRAÇÃO - O ATO NA (IM)POSSIBILIDADE DA AÇÃO}

[...] O poder só é efetivado enquanto a palavra e o ato não se divorciam, quando as palavras não são vazias e os atos não são brutais, quando as palavras não são empregadas para velar intenções, mas para revelar realidades, e os atos não são usados para violar e destruir, mas para criar relações e novas realidades. (ARENDT. 1997. p. 212)

$\mathrm{O}$ ato infracional é um ato de violência. Para o seu exercício o autor e a vítima sofreram violências: humilhações sofridas ao longo de anos, violência física pelo uso da força, violência na surpresa do ato, violência na subtração de algo, violência pelo desrespeito às regras coletivas, violência do desrespeito aos direitos humanos, entre tantas outras.

Na busca por encontrar qual seria a maneira de organizar a convivência entre os homens sem a necessidade do uso da força e da violência, algumas idéias foram levantadas por Arendt (1988).

As leis podem funcionar como disciplinadoras do homem na coletividade sem o uso da força, mas elas não garantem a isenção de que um grupo ou indivíduo não se sobreponha a outros. As leis são construídas para garantir os interesses de quem as construiu, podendo assim haver violência no controle do poder. É o que ocorre por exemplo com a violência permitida para que seja respeitado o direito à propriedade privada.

Outra maneira da autoridade ser reconhecida seria pela apresentação de circunstâncias que compelem a mente humana a pensar de determinada maneira, ou seja, ocorrendo um controle pela razão e pelo conhecimento. Porém, só uma minoria tem acesso a evidências baseadas no desenvolvimento da ciência, o que lança o problema de como convencer a maioria sem o uso da violência.

A autoridade é necessária e implica uma relação desigual entre duas pessoas ou dois grupos. Para que ela aconteça aquele que é comandado deve legitimar o poder do outro. Isso só pode ocorrer sem o uso da força quando o elemento coercitivo ou de convencimento está na relação estabelecida entre as partes. 
Historicamente, essa situação ocorre nas relações entre mestre e aprendiz. Porém, é importante ressaltar que essas relações foram assim estabelecidas dentro de um contexto, não foram dadas naturalmente, foram construídas por homens na relação com outros homens.

A análise da autora (ARENDT. 1988) aponta que os gregos pensavam a autoridade baseada no conhecimento e aptidão de peritos, ou seja, na produção da ciência. Os romanos acreditavam que o que pode sustentar a autoridade de uns sobre outros é o respeito e reconhecimento da sabedoria das gerações passadas, com seus conhecimentos sendo atualizados a cada momento presente.

"Enquanto essa tradição fosse ininterrupta, a autoridade estaria intata, e agir sem autoridade e tradição, sem padrões e modelos aceitos e consagrados pelo tempo, sem o préstimo da sabedoria dos pais fundadores, era inconcebível.” (ARENDT. 1988. p. 166)

Assim, a persuasão exercida a partir do conhecimento e da razão, ou a partir do respeito à tradição dos antepassados não são auto-evidentes, foram construídas. Atualmente foi perdido, na sociedade brasileira, o respeito aos mais velhos pela sabedoria que possuem.

A perda da valorização do passado como fundador da relação de autoridade entre as pessoas fez com que atualmente o homem tenha perdido a noção de história e de pertencimento a um contexto. Assim a aparência é de que as coisas sempre foram da mesma maneira. De que elas são como são por forças naturais ou individuais.

Ao mesmo tempo, o valor da autoridade daquele que tem o conhecimento - do educador ou sábio - também se perdeu. A crise moderna da perda da autoridade transformou a violência em uma forma legitimada pela minoria para organização da maioria.

Ao longo da história do ocidente o povo foi persuadido do que era certo ou errado, tanto política como moralmente, de acordo com os interesses de uma minoria. A ideologia dominante foi e continua sendo imposta tanto pela 
produção de "ciências" comprometidas com o status quo, quanto com a valorização de um passado em que as regras são determinadas pela tradição do poder e prevalência do interesse de alguns sobre muitos.

O convívio humano necessita do poder de alguns, legitimado pela maioria. Para o exercício do poder, como afirma a autora, não é necessário a força dos atos, nem o esvaziamento de sentido das palavras. O poder é a condição humana da pluralidade.

$\mathrm{Na}$ sociedade capitalista ocidental o interesse das classes que detêm o capital predomina sobre os que possuem apenas a sua própria força de trabalho. A soberania de um sobre outros é exercida com o uso da violência física ou emocional, explícita ou camuflada.

A violência pode destruir o poder, mas nunca substituí-lo. Por outro lado, uma ameaça ao poder é a união da força da maioria. Por isso aqueles que têm o poder, sistematicamente minam a união do pensamento e da força do grupo oponente e numericamente maior.

A alienação do trabalhador em relação à expropriação de suas forças é uma forma de coerção, sem o uso aparente da violência. Mas na realidade, o não uso da força física para obrigar o trabalhador a se sujeitar as condições inumanas de trabalho e vida não significa que esta não seja uma relação violentadora. Na sociedade atual a relação entre os homens foi violentada pelo capital.

Hanna Arendt (1988) afirma que todas as atividades em que o homem se confronta com a natureza - o ato de fabricar e produzir objetos - há necessariamente um elemento de violência.

Já as relações que ocorrem entre os homens, como a fala e a ação, não seriam necessariamente violentas. Para isso, os homens precisariam estar livres das necessidades biológicas de existência, reunidos em um espaço público com outros homens e em uma relação de igualdade entre todos. Nessas condições a palavra e a ação do homem livre poderiam prevalecer. 
"[...] sempre que o mundo artificial não se torna palco para ação e discurso - como ocorre com comunidades governadas despoticamente que os banem para a estreiteza dos lares, impedindo assim o ascenso de uma esfera pública - a liberdade não possui realidade concreta" (ARENDT. 1988. p.195)

Os moradores das periferias das capitais brasileiras que sofrem com a violência urbana, com precárias condições de transporte, moradia, trabalho, alimentação etc, permanecem grande parte do seu pouco tempo livre (aquele não dedicado ao trabalho) resolvendo questões da sobrevivência e, quando esta consegue ser sanada, as energias física e mental já não estão disponíveis para encontros públicos. Não há espaços de liberdade nessas condições.

Os homens não podem exercer sua liberdade, uma vez que há outros seres humanos que não estão nessa condição. A liberdade de um depende da liberdade de todos. E, liberdade não deve ser confundida com livre arbítrio como ocorreu com esse conceito na tradição cristã, nem com soberania ou poder de um sobre outros.

Para Arendt (1997. p.350) "[...] liberdade não é a liberdade moderna e privada da não-interferência, mas sim a liberdade pública da participação democrática [...] liberdade exige um espaço público da palavra e da ação."

A liberdade só pode existir em condições de atualização do novo em cada ser que surge no mundo. A liberdade "[...] só se desenvolve com plenitude onde a ação tiver criado seu próprio espaço concreto onde possa, por assim dizer, sair de seu esconderijo e fazer sua aparição." (ARENDT. 1988. p. 218)

Ao cometer uma infração o adolescente pobre atualiza princípios: as humilhações e violências sofridas ao longo da sua vida individual, mas também àquelas vividas historicamente por seu grupo de origem, as faltas sentidas, os desejos não satisfeitos.

Os sentimentos atualizados em cada ato são atravessados por determinações sociais, de classe e individuais. Cometer um ato infracional não é uma questão de liberdade individual ou de ausência dela, mas de julgamento 
do certo e do errado em cada momento. E, sem dúvida, as condições que constroem esse julgamento mudam de acordo com a cultura, com a classe social, com condições individuais de existência.

A ação do adolescente quando comete uma infração não é um ato livre: ele não foi obrigado a isso, mas não há a ação de um homem livre que atualiza e transforma o passado no presente de cada ação.

Com seu ato ele acredita estar restaurando sua dignidade, sua liberdade e inclusão no mundo do consumo de bens e serviços. Ele busca preencher um espaço anteriormente ocupado pela sensação de ter sido negligenciado pela família, pela escola, pela sociedade.

A infração o coloca na posição daquele que desrespeitou o pacto da propriedade privada e o põe em evidência social. $\mathrm{O}$ adolescente que comete um ato infracional não pode ser libertado das amarras que o prendem a uma história pessoal e coletiva.

Como afirmo no título desse capítulo: o ato na (im)possibilidade da ação. $\mathrm{O}$ ato em uma ação possível frente a sua história - a violência sofrida é atualizada em cada ato violento. $\mathrm{O}$ ato na impossibilidade da ação. $\mathrm{O}$ único ato possível quando a ação e a palavra entre homens livres não se torna possível o humano impossibilitado por condições miseráveis de existência impõe a desumanização do outro.

$\mathrm{O}$ adolescente pobre que comete um ato infracional está impedido na sua condição humana.

Hanna Arendt em A Condição Humana (1997) apresenta o que chama de condições da existência humana: o labor, o trabalho e a ação. Define o labor como a atividade necessária à sobrevivência do corpo humano e consequiente reprodução da espécie. Para essa sobrevivência os objetos produzidos são consumidos. “[...] todo labor nada deixa atrás de si: o resultado do seu esforço é consumido quase tão depressa quanto o esforço é despendido.” (1997. p. 98) 
Os produtos provenientes de um só homem podem assegurar, além de sua própria existência, a de outras pessoas também. O labor não tem começo nem fim, preso que está ao processo vital.

O trabalho é a atividade que produz a permanência e existência do homem no mundo. Corresponde à produção de objetos para o uso, que não são consumidos imediatamente. Eles podem durar mais que o tempo de uma vida individual, dando assim a possibilidade da existência histórica.

$\mathrm{Na}$ atividade do trabalho o homem produz os artefatos humanos a partir de suas mãos e transformação da natureza. $O$ trabalho possui uma produtividade própria, ou seja, a força humana. Essa força não se esgota quando o produto estiver acabado, nem quando produziu o suficiente para sua própria sobrevivência.

A ação é a atividade que ocorre diretamente entre os homens, sem a mediação de objetos. Ela depende da pluralidade humana, do fato de nunca existir um ser humano igual ao outro. Ela cria a condição para a lembrança e a história. A ação é irreversível, tem um começo previsível, mas não tem fim.

A autora propõe distinção entre atividades que comumente são chamadas apenas por trabalho. Sustenta também que o trabalho executado por operários na sociedade capitalista moderna pode ser enunciado como um tipo de labor, dadas as condições de sua realização.

[...] enquanto a especialização do trabalho é essencialmente guiada pelo próprio produto acabado, cuja natureza é exigir diferentes habilidades que, em seguida, são reunidas e organizadas em um conjunto, a divisão do labor, pelo contrário, pressupõe a equivalência qualitativa de todas as atividades isoladas para as quais nenhuma qualificação é necessária; e estas atividades não têm uma finalidade em si mesmas; mas representam, de fato, somente certas quantidades de "labor power", somadas umas às outras de modo puramente quantitativo." (ARENDT. 1997. p. 135)

A produção de objetos de uso que são feitos para serem consumidos rapidamente, as condições de trabalho que levam o trabalhador a uma atividade que não tem fim, a divisão do trabalho que torna as pessoas responsáveis por uma ínfima parte que se juntará com outras para a construção do objeto, acrescido do fato que o trabalhador jamais vê a coisa pronta, nem 
tampouco tem dinheiro para consumi-la, caracterizam o labor - aquela atividade em que as "fadigas e penas" do organismo só terminam quando o ser biológico morre.

A revolução industrial substituiu todo o artesanato pelo labor, o resultado foi que as coisas do mundo moderno se tornaram produtos do labor, cujo destino natural é serem consumidos, ao invés de produtos do trabalho, que se destinam a ser usados. (...) mas a produção em massa seria, além disso, completamente impossível sem a substituição de trabalhadores e da especialização por operários e pela divisão do labor. (ARENDT. 1997. p. 137)

Os objetos de uso produzidos de forma abundante na sociedade atual foram transformados em objetos de consumo. Eram feitos para durar, mas na sociedade atual devem ser substituídos sempre, e cada vez mais rápido, para que a máquina capitalista possa continuar rodando no seu ritmo alucinante. $\mathrm{O}$ consumo nunca satisfaz e a pessoa é sempre impelida a obter novos objetos, mesmo que os anteriores ainda estejam em bom estado. O consumo atual devora e destrói os objetos e as pessoas.

Em nossa necessidade de substituir cada vez mais depressa as coisas mundanas que nos rodeiam, já não podemos nos dar ao luxo de usá-las, de respeitar e preservar sua inerente durabilidade, temos que consumir, devorar, por assim dizer, nossas casas, nossos móveis, nossos carros, como se estes fossem as "boas coisas" da natureza que se deteriorariam se não fossem logo trazidas para o ciclo infindável do metabolismo do homem com a natureza. (ARENDT. 1997. p. 138)

O consumo exagerado transformou tudo e todos em "utilidades": objetos úteis são meios para se chegar a um fim específico, pessoas "úteis" são aquelas que ajudam o outro a obter algo. Todos estão se relacionando com objetivos individualistas para se sentir melhor ou superior a outros. Como se todas as coisas e pessoas só existissem como meios para se chegar a um fim

A condição atual de emancipação do trabalhador, que é livre para vender sua força de trabalho em contraposição ao trabalho escravo, não tornou o homem um ser livre. Ele está submetido às infinitas necessidades do corpo que consome. Sabe-se que as necessidades do corpo humano impõem o exercício do labor. Somente quando essas condições, necessárias para a 
existência do corpo físico forem satisfeitas torna-se possível pensar em homens livres - e para sanar essas necessidades, certa dose de violência e força são necessárias. A sociedade do labor e do consumo, como define Arendt (1997), exige a perda da individualidade e transforma todos em um só corpo, dependente do ritmo biológico.

Segundo Arendt (1997. p. 40) "[...] a violência é o ato pré-político de libertar-se da necessidade da vida para conquistar a liberdade do mundo." Nesse mundo, a liberdade possibilitaria a palavra e a ação no convívio com outros homens livres, iguais em condição de liberdade e diferentes na diversidade de possibilidades de ser de cada um.

A sociedade moderna - pautada na exploração da força de trabalho que transformou em labor; na ênfase ao consumo exagerado de bens que deveriam ser duráveis, além do consumo de bens necessários à sobrevivência; na impossibilidade do aparecimento do diferente - aboliu a ação espontânea e a reação inusitada, exigindo que todos ajam igualmente, como cópias de um único modelo.

A ação e o discurso são atos exclusivamente humanos que foram banidos da esfera pública, mas são impossíveis na esfera privada, do lar. Ação e discurso pedem a existência de outros homens, iguais em condições de liberdade e aparição; plurais em sua possibilidade de existir. Sem essas características não há convivência humana. A realidade do mundo está presente para o homem na aparição de, e com outros homens.

"[...] Somente quando as coisas podem ser vistas por muitas pessoas, numa variedade de aspectos, sem mudar de identidade, de sorte que os que estão à sua volta sabem que vêem o mesmo na mais completa diversidade, pode a realidade do mundo manifestar-se de maneira real e fidedigna." (ARENDT. 1997. p. 67)

O homem que vive impedido da aparição pública que permite a espontaneidade, não se dá a conhecer, fica privado da relação com outros homens, é como se não existisse. "O que quer que ele faça permanece sem 
importância ou consequiência para os outros, e o que tem importância para ele é desprovido de interesse para os outros". (ARENDT. 1997. p. 68)

A condição para a existência desse espaço de aparência na esfera pública é a pluralidade entre os homens. Atualmente a pluralidade, a espontaneidade e a diferença entre as pessoas estão impedidas pela valorização do único, de todos pensarem e agirem da mesma forma.

A impossibilidade de aparição dos jovens das periferias das grandes cidades leva-os a sentirem-se sem importância, como se nada que fizessem fosse visto ou ouvido por outros. Isso fica claro na fala do jovem entrevistado, referindo-se ao período em que estava cumprindo a medida socioeducativa de semiliberdade:

Semiliberdade, isso, aí tipo... na semiliberdade a gente podia todo final de semana ir pra casa, né? Ficar com os familiares, e nisso meu, meu avô, ele não me aceitou de volta, ele não me aceitou de volta e isso foi inspiração nenhuma, falei: ah ele não me quer de volta, não tenho mais ninguém, então eu vou... me afundar, entendeu? Eu tô nessa vida, eu vou prosseguir do jeito que eu estou aí... (Lucas)

Em conversas informais com adolescentes que cometeram atos infracionais, quando inquiridos sobre a vida arriscada que a prática infracional proporciona, ouvi a seguinte frase: "Se morrer, enterra, vem outro e faz o serviço...." Essa é a máxima sensação de não pertencer à humanidade. É o desespero de quem não pode aparecer.

Na sociedade atual a admiração pública está sendo consumida como status. A necessidade de aparição para manter a realidade do mundo foi esvaziada de sentido e transformada em alimento a ser consumido para enaltecer a vaidade individual.

Se a humanidade precisa da instância pública, pode-se afirmar que ela necessita, na mesma medida, da proteção da esfera privada. É nesse contexto que as necessidades vitais da existência humana podem ser garantidas. Nesse contexto a autoridade e a proteção da família são fundamentais para o desenvolvimento psíquico do indivíduo. 
Se o ser humano precisa do labor para sua sobrevivência física, da ação e do discurso no espaço público com outros homens para garantir sua pluralidade e liberdade, também necessita do trabalho para a produção de bens que garantem a permanência e durabilidade do mundo. A produção de objetos que não são consumíveis, como as coisas que são usadas de acordo com certos hábitos e cultura e com as quais nos habituamos, garante a familiaridade do mundo e o intercâmbio entre os homens.

"A realidade e a confiabilidade do mundo humano repousam basicamente no fato de que estamos rodeados de coisas mais permanentes que a atividade pela qual foram produzidas, e potencialmente ainda mais permanentes que a vida de seus autores." (ARENDT. 1997. p.107)

A produção de objetos a partir do trabalho, com sua história e cultura garantem ao homem uma existência estável nesse mundo de constantes transformações. Aqueles objetos que atravessam gerações e que duram mais que a existência individual contam a história de uma família, de uma comunidade, de um povo. Essa construção garante ao homem sua permanência no mundo, seu pertencimento como ser humano.

Os objetos produzidos pelo trabalho humano e que se destinam ao uso, transcendem sua utilidade na medida em que dão sentido à vida humana. Carregam a memória e a história de um povo.

Quando os jovens dessa pesquisa relataram que um dos motivos que os levaram a entrar na criminalidade foi a obtenção de objetos (como roupas, tênis, motos) uma observação torna-se fundamental: os objetos são necessários para a vida do homem - as roupas abrigam o corpo, o tênis protege o pé, o veículo facilita o deslocamento.

Mas os jovens almejam objetos valorizados socialmente, que possuem uma marca ou modelo específico. $\mathrm{O}$ seu desejo por objetos transcende a pura utilidade, transcende a proteção do corpo. Os objetos desejados são frutos de um mecanismo perverso de imbuir certas necessidades - o fetiche exercido pelas mercadorias. 
A prática infracional impede o aparecimento do jovem e desse outro, detentor do dinheiro e do desejo do adolescente. Nos trechos abaixo é possível perceber como o outro não pode aparecer:

Nesse dia era a tal da saidinha, pra que? Ninguém ia gastar o dinheiro que a gente sempre dividia, ninguém ia gastar o dinheiro que a gente ia comprar arma e droga, comprar arma e droga....ia, aí a gente fizemo a (?) $e$ ganhamo 4 mil e 500, nesse dia que era de um boy que estava trabalhando, foi pegar... provavelmente deve ter pegado dinheiro da empresa pra pagar seus funcionários, ou pra pagar alguma conta da empresa e a gente acabou assaltando esse, esse funcionário da empresa que era um boy, né? Que é aquele... é o ...é o cara da empresa que faz o... leva documento, faz pagamentos... e aí ele não estava fazendo pagamento, ele sacou esse dinheiro, ele sacou esse dinheiro e esse cara que estava de terno e gravata, com... com a arma na cintura é... a gente falava que ele ia escalar a vítima, ele escalou a vítima que era a... que era escolher a vítima e a quantidade de dinheiro, quem que era.... e aí ele deu o sinal pra gente e eu não pensei duas vezes em ... em por a arma... a gente já tava com um oitão que era do cara da Lotérica, que era o cara da Lotérica, que era um oitão que era Canela Seca... é um 38 que ele é mais fino, se não me engano.. que eu não entendo mais, que eu nunca mais peguei numa arma, assim, mas se eu não me engano ele tinha 5 tiros assim, no tambor e ele era fino, assim, um pouco grande e o cabo, acho que chamava de Canela Seca porque o cabo era muito fino e era, era muito ruim.. (rsss) era muito ruim.... e aí eu meti... eu coloquei a arma sobre a cabeça da... do cara, que era... como a gente falava era... eu meti a peça na cabeça do Beco e... dei a voz de assalto... e aí a gente... o cara tipo... tinha mais um cara com a gente, nesse dia a gente tinha ido em 3 só, e aí o que tava com nós fez o recolhe, que era pegar o dinheiro e pegar minha arma e sair correndo, só que nesse dia, tinha uma banca de jornal que tava bem escondida, tinha uma viatura vindo na faixa que era de ônibus e tava vindo, tava vindo de contra mim, só que eu... eles não tinham visto eu assaltando a vítima, na hora que eu pus o revólver na cintura que eu pus a peça na cintura eles... deram aquela sirene que fez uieuie lá, nieuieuie (rsss) eu lembro e aí eu... eu não tinha nenhuma bala dentro do revólver, não, minto, eu tinha uma bala dentro do revólver e aí eu jog... dei um soco na vítima, peguei ela e joguei assim ela... enquanto o cara que tinha ficado com a Glock, que tinha.. que tinha bala, já tava na outra esquina, não tinha como, não tinha como ele, na verdade não tinha como ele vir, né... que eu era de menor também ele não... a gente falava que mesmo... que de menor não precisa se arriscar tanto pra... pra salvar um outro, só se estivesse bem próximo, bem junto, só que ele saiu... saiu e foi pra casa e o outro que pegou minha... que pegou o dinheiro também foi... foi pra casa....(Alex)

bom e aí eu.... a gente assaltou a vítima dentro de um bar e a vítima não queria dar o dinheiro, o tiozão não queria dar, não queria dar de nenhuma maneira.... e tava dentro do bolso, ela tinha colocado em dois bolsos, pos um tanto num bolso e o outro no outro bolso. Só que quando ela chegou no bar ela entrou dentro do banheiro direto... a gente tomou uma coca-cola esperando ele sair, quando ele saiu ele tomou, pediu uma cerveja, quando 
ele pediu uma cerveja pro dono do bar, a gente deu voz de assalto e aí o dono do bar é.... deitou no chão e tinha mais duas pessoas no bar também que ficou assustada e... colocou a mão na cabeça e... não lembro se só.... só levantou as mãos, mas a vítima falou que não ia dar o dinheiro... e aí o que que eu fiz, na revolta de que ela não dava o dinheiro, e meu, meu parceiro entre aspas, que... que tava ali comigo, que pegou... que queria também o dinheiro que tava na... tava na fita, na missão, né? Como a gente dizia.... que tava no lugar comigo, ele não conseguia encontrar o dinheiro... só que ele tinha entrado dentro do banheiro, a vítima, e eu acho que colocou no... colocou por dentro da calça, né? Por dentro da cueca dele e aí ele procurando no bolso ele não conseguia, aí o cara falou que não tava com dinheiro, que não tava com dinheiro, nisso eu já... nessa hora eu me injuriei e o meu parceiro também, eu dei um soco na barriga do car., da vítima, eu dei duas coronhadas na cabeça e uma no nariz, nisso começou a escorrer sangue, começou a sangrar e o cara caiu no chão, na hora que o cara caiu no chão, aí ele pois.. é... bateu assim no saco do cara, o meu parceiro botou assim a mão por dentro da calça e pegou o, pegou o dinheiro, pegou um ... um bolo de dinheiro - assim mais ou menos, dessa altura assim (fazia o gesto) - tinha 50, 100 reais embolado num elástico, aí o cara tava com 50 reais só no bolso de trás, que era, eu acho que pra pagar a cerveja... pra trocar esse dinheiro ... (Alex)

O terror da violência de um adolescente está no fato de que suas vítimas são inocentes, escolhidas aleatoriamente, independentes de condutas individuais.

"[...] a perda do respeito nos tempos modernos, ou melhor, a convicção de que só se deve respeito ao que se admira ou se preza, constitui claro sintoma da crescente despersonalização da vida pública e social" (ARENDT. 1997. p.255)

A ação pede o discurso para sua identificação e apresentação do autor. Quem age pensa e executa sua ação. Os adolescentes que cometem ato infracional agem, são atores e autores de seus atos. Mas a ação, quando desacompanhada do discurso que impede a revelação de seu autor/ator transforma-se em repetição de atos mecânicos.

$\mathrm{O}$ ato infracional é a repetição de atos onde o autor torna-se impossibilitado de aparecer, ao mesmo tempo e contraditoriamente que aparece na sua ação de destruição. Aparece o adolescente pobre que deseja objetos valorizados socialmente (ou o dinheiro para sua aquisição). Aparece a violência e humilhação com que foi tratado ao longo da vida. Aparece o mecanismo perverso da sociedade de expropriação de alguns para acumulação 
de outros. Não aparece o jovem, o agente: único, com um nome, uma história, uma família - Alex, Breno, Douglas, Lucas. Nesse caso, a ação perdeu o sentido de aparição do sujeito. A ação é o ineditismo e o novo começo de cada homem na Terra.

A ação é um processo iniciado por um indivíduo que nunca poderá prever com certeza o resultado dela, pois cada ação desencadeia inúmeras outras. Retrospectivamente o autor da ação poderá conhecer a real profundidade e desdobramento de seu ato.

[...] A única solução possível para o problema da irreversibilidade - a impossibilidade de se desfazer o que se fez, embora não se soubesse nem se pudesse saber que se fazia - é a faculdade de perdoar. A solução para o problema da imprevisibilidade da caótica incerteza do futuro, está contida na faculdade de prometer e cumprir promessas. (ARENDT. 1997. p.248)

O conflito pede a palavra para a sua resolução. No mundo contemporâneo a palavra e o encontro com o outro estão impedidos pela violência do dia-a-dia, pela opressão da indústria cultural e valorização do consumo, como já foi explicitado anteriormente. O poder humano de cumprir promessas e de perdoar está sendo pouco utilizado na sociedade atual.

O conflito é inerente à existência humana. Através dele as contradições podem ser superadas. As revoltas e revoluções (ponto máximo de situações conflituosas) são tentativas de rupturas com um passado e instauração de um novo futuro, que apesar de romper com certa tradição, deve levá-la em consideração nas suas aspirações. O sentido da história sempre está presente nesse processo.

A ação e o espaço público de aparição do homem só podem ser possíveis pelo controle mútuo entre os homens e pela capacidade de cumprir promessas. A moralidade de um povo e seus costumes controlam a ação de seus membros.

Quando um jovem se revolta individualmente, rompe com os laços sociais comuns, ele busca uma ruptura e uma atualização de um passado que 
tem uma história e que deve ser levada em consideração. Ele não busca uma transformação social, mas provoca uma mudança em sua vida.

Revoltar-se pode significar cometer um ato infracional. No novo futuro possível ele passa a ser o infrator, o perigoso, mas também o questionador, o valente. Essa ruptura passa a ser vista pela sociedade como individual, sendo que ela é também, histórica e coletiva.

Há a necessidade de se levar em consideração a história anterior, vivida por um indivíduo que está inserido em uma determinada classe social, em um determinado tempo, em uma dada comunidade. A descontinuidade entre o passado e o futuro - a perda da história - transforma os homens em exclusivos seres biológicos. Perde-se o humano no homem. Perde-se a criatividade na possibilidade desse novo ser que habita o mundo.

Cada ser humano "[...] inserindo-se entre um passado infinito e um futuro infinito, deve descobri-lo e, laboriosamente, pavimentá-lo de novo." (ARENDT. 1988. p.40) Cada ser humano deve, através da ação, inserir-se nas possibilidades e potencialidades humanas. A ação revela o agente e refere-se a um contexto.

Os homens se inserem no mundo com palavras e atos. Essas ações garantem ao indivíduo a sua existência singular. A ação não ocorre por necessidade do corpo como o labor, nem pela necessidade de objetos como o trabalho. A ação pode ser estimulada, mas não treinada.

Onde, na sociedade atual, existe esse espaço de troca e liberdade? A escola poderia cumprir esse papel, mas não o faz. E da maneira como está organizada, não pode fazer.

"Se a ação, como início, corresponde ao fato do nascimento, se é a efetivação da condição humana da natalidade, o discurso corresponde ao fato da distinção e é a efetivação da condição humana da pluralidade, isto é, do viver como ser distinto e singular entre iguais." (ARENDT. 1997. p.191)

A revelação do agente no ato acompanhado de discurso, o aparecimento desse ser singular que está inserido em um contexto, em uma "teia de 
relações", produz conseqüências imediatas. Cada ato desencadeia novas inserções nessa teia de relações entre as pessoas. A resposta a um ato está imbricada em uma teia de relações que influencia e sofre influência para uma nova ação, de maneira dialética.

Sem a ação para pôr em movimento no mundo o novo começo de que cada homem é capaz por haver nascido, "não há nada que seja novo debaixo do sol", sem o discurso para materializar e celebrar, ainda que provisoriamente, as coisas novas que surgem e resplandecem, "não há memória", sem a permanência duradoura do artifício humano, "não haverá recordação das coisas que têm de suceder depois de nós". E sem o poder, o espaço da aparência produzido pela ação e pelo discurso em público desaparecerá tão rapidamente como o ato ou a palavra viva. (ARENDT. 1997. p.216)

O espaço que permite a aparência do sujeito, sua ação e discurso, é fundamental para que ele se constitua único e diferente dos outros e, possa também, partilhar a história da sua comunidade, do seu povo.

Atualmente esse espaço de aparição está impedido. Não há um convívio desinteressado entre as pessoas, a ação e o discurso que mostram o agente estão impedidos. $\mathrm{O}$ contato entre as pessoas estabelece-se na base de interesses individuais ou da troca - daquele que vende ou compra um serviço ou força de trabalho. Estabeleceu-se uma relação entre mercadorias e não entre seres humanos. Nesse contexto está-se constituindo a juventude brasileira.

Nessa sociedade em que as relações entre as pessoas são mantidas por interesses e fetichizadas pelo desejo de mercadorias sempre diferentes, o individualismo está em toda parte.

Com Sales (2004. p. 168) afirmamos que:

No caso dos adolescentes infratores, na impossibilidade de conquistarem o direito a essa participação na esfera pública e, por conseqüência, a chance de serem vistos e reconhecidos como sujeitos, eles adotam a violência como estratégia e esta se torna o seu principal passaporte para a visibilidade numa era de cidadania virtual.

Marcos foi um garoto que conheci quando trabalhei com crianças e adolescentes em situação de rua em uma área nobre da cidade de São Paulo: o movimentado cruzamento das avenidas Faria Lima e Rebouças. 
O garoto contava que tinha um irmão gêmeo que fora levado em adoção por seu pai, ainda bebê, no momento do falecimento de sua mãe. Marcos brigava constantemente com o genitor porque achava que sua situação precária de vida devia-se ao fato de ter permanecido com ele.

Moravam em um bairro de moradias populares em uma cidade da região metropolitana de São Paulo. As relações desgastadas e o alcoolismo do pai impulsionaram o garoto para a rua.

Franzino e de fisionomia sempre fechada, Marcos era usuário freqüente de cola e crack. Foi considerado muito perigoso pelos moradores, comerciantes e policiais da região. Era conhecido por todos por sua agressividade, mendicância e pequenos furtos.

A relação que o garoto estabeleceu com os educadores de rua também era de medo. Ele ameaçava e brigava com todos. Vários pediram transferência por sentirem-se amedrontados. Quando ameaçou uma educadora com um pedaço de ferro pontiagudo tive a certeza que eu e ele havíamos construído um vínculo de confiança, pois consegui fazê-lo desistir de agredi-la. Um boletim de ocorrência de ameaça foi feito e os policiais da região o levaram para a Febem.

Havia demorado alguns meses para conquistar a confiança daquele garoto. Isso se deu depois da percepção de que a sua maneira de apresentar-se e relacionar-se com todos era impondo medo. Quem conseguisse romper essa enorme barreira inicial encontrava um garoto de apenas 13 anos, amedrontado pelas vivências da rua e pelo uso contínuo de crack.

A condição de sua visibilidade era o medo. Uma visibilidade perversa que o impedia de entrar em contato com as pessoas e consigo mesmo.

Visitei-o na Febem algumas vezes. Com sua permissão, realizei visita domiciliar no intuito de conhecer seu pai e sua história. Havia um longo trabalho a fazer...

Por questões institucionais mudei de setor e passei a trabalhar com as crianças em situação de rua na região central da cidade. Nunca mais o vi. 
Soube que quando saiu da Febem me procurou. Não pudemos nos encontrar. Sua história ficou comigo....

Para os transeuntes, comerciantes e moradores da Avenida Faria Lima pouco importava quem era o Marcos e qual sua história. O desejo de todos era de que aquele que aparecia - o terrível Marcos - fosse retirado das ruas daquela região e fosse para a Febem, para o SOS Criança ou para a periferia onde morava seu pai. $\mathrm{O}$ contato com o outro estava impedido na visibilidade perversa dos meninos do farol.

A visibilidade conquistada por aqueles sujeitos em sua denúncia-movimento, mediada muitas vezes pela violência, é todavia paradoxal: de um lado, a sociedade tende a não considerar a fala/ações de seres [ditos] anti-socias [...] que romperam com o pacto da cidadania regulada e da ótica de trabalho. De outro, não fosse a insubmissão de que são portadores, não se enxergaria as condições subumanas a que a maioria dos que sofrem privação de liberdade está submetida. (SALES. 2004. p.194)

Quem não aparece não tem visibilidade, está fora da representação e do discurso. $\mathrm{O}$ ato infracional, ou as rebeliões, seriam uma tentativa de tornar visível. Visibilidade essa que se dá de forma perversa, pois se deu à custa da anulação do sujeito e sua subjugação à violência e à ordem existente.

Os adolescentes pobres e os que cometem atos infracionais permanecem na invisibilidade até que seus atos "transgressores" ou "violentos" sejam visíveis por uma espetacularização midiática, dando a eles uma projeção social perversa [visibilidade perversa] pois são usados como contra-modelos para o restante da população. (SALES. 2004. p. 86)

Essa é a maneira perversa que a sociedade atual permite que seus jovens sejam vistos e ouvidos. Porém o seu ato não traz a sua humanidade perdida, ao contrário, os expulsa cada vez mais da possibilidade de ser um indivíduo autônomo, com desejos, com um nome, pertencente a uma comunidade.

Muitos jovens com quem conversei durante todos esses anos de trabalho com adolescentes que cometeram atos infracionais relataram sua inconformidade ao conseguirem freqüentar espaços profissionalizantes, 
culturais ou de lazer apenas depois de terem cometido uma infração e terem sido inseridos em uma medida socioeducativa. Está aí um exemplo de perversidade nas políticas sociais para a juventude. A visibilidade promovida pelo ato infracional transformou o adolescente em um sujeito inserido em políticas para a juventude, algo que não foi possível antes dele cometer uma infração.

Uma das maneiras de se diminuir os índices de infração entre os jovens seria, além da melhora básica em suas condições de vida, com acesso a saúde, educação, moradia e trabalho, o oferecimento de espaços de cultura e lazer ou outros locais em que o jovem poderia ser ele mesmo para se constituir como um ser humano único.

A existência de espaços públicos, onde os sujeitos pudessem aparecer e serem ouvidos, um espaço que fosse democrático e humano, onde todos poderiam se encontrar em paridade de condições, garantiria a realidade da experiência de cada ser e permitiria condições para a humanidade de todos. 
Capítulo 8 - AS VIOLÊNCIAS 


\title{
8. AS VIOLÊNCIAS
}

A melhor forma de determinar se uma pessoa foi expulsa do âmbito da lei é perguntar se, para ela, seria melhor cometer um crime. Se um pequeno furto pode melhorar a sua posição legal, pelo menos temporariamente, podemos estar certos de que foi destituída dos direitos humanos. Pois o crime passa a ser, então, a melhor forma de recuperação de certa igualdade humana, mesmo que ela seja reconhecida como exceção à norma. (ARENDT. 2004. p. 320)

A violência alarma, cancela os nomes, invade as construções e o vizinho, emudece, mata. Mata a vítima, mata o matador: vira "vulto", um "elemento", diz a polícia. (GONÇALVES FILHO. 1995. p.106)

\subsection{Os dados que ajudam a compreender o fenômeno}

\author{
A violência ${ }^{19}$ no Brasil não é fenômeno recente. Desde a época do \\ Brasil colônia ela se faz presente como forma de resolução de conflitos sociais \\ e em tensões nas relações intersubjetivas. Já durante o período republicano a \\ violência estava enraizada e positivamente valorizada. A violência era, e é \\ desde então, legitimada para conter conflitos no campo e na cidade. \\ Na história do Brasil residem
}

[....] as raízes de uma sociedade autoritária, cujas principais características eram segregação racial, desprezo pela massa despossuída, naturalização da grande distância social em termos de condições de vida e trabalho, banalização da violência como recurso à violência privada contra desde os escravos até os trabalhadores [...] Valores e práticas que constituem traços indeléveis no inconsciente coletivo cultural e jurídico-institucional brasileiro. (SALES. 2004. p.41)

\footnotetext{
${ }^{19}$ Conceito de violência segundo ZALUAR (1999) violência vem do latim violentia que remete a vis (força, vigor, emprego de força física ou os recursos do corpo para exercer sua força vital). Essa força torna-se violência quando ultrapassa um limite ou perturba acordos tácitos e regras que ordenam relações, adquirindo carga negativa ou maléfica. É portanto a percepção do limite e da perturbação (e do sofrimento que provoca) que vai caracterizar o ato como violento, percepção essa que varia cultural e historicamente. (ZALUAR, A. Violência e Crime. In MICELI, Sergio (org) O que ler nas ciências sociais brasileiras. São Paulo: Sumaré. 1999. V.1. 13-107.) citado por ADORNO, Sérgio. Exclusão socioeconômica e violência urbana. - NEV- USP; Preparado para o ciclo de Conferências "Sociedad sin Violência", promovido pelo PNUD - El Salvador Disponível em <http:// www.nevusp.org/downloads/down77.zip>. Acessado em 21 nov 2006.
} 
A partir dos anos 80 do século passado verifica-se no Brasil, seguindo uma tendência mundial, um aumento da violência urbana. Sérgio Adorno (2002) aponta quatro aspectos dessa violência: crescimento dos crimes contra o patrimônio e de homicídios dolosos; emergência da criminalidade organizada (tráfico de drogas); graves violações de direitos humanos e explosão de conflitos nas relações intersubjetivas.

As causas para o aumento da violência urbana no Brasil, segundo Sergio Adorno ${ }^{20}$ seriam:

$\checkmark$ mudanças na sociedade e nos padrões convencionais de delinqüência e violência - nos últimos anos ocorreram mudanças nas relações entre capital e trabalho, nas relações entre as pessoas, entre os indivíduos e o Estado e entre os próprios Estados. Essas mudanças repercutiram na natureza dos conflitos sociais e na maneira de sua resolução. Assim, transformaram-se os padrões de delinqüência: aumento do crime organizado (tráfico mundial de drogas), do emprego da violência, da corrupção dos agentes do setor público e graves violações dos direitos humanos.

$\checkmark$ crise no sistema de justiça criminal - mudaram os padrões de violência e o sistema de justiça não acompanhou essas mudanças. Ele deixa impune muitos crimes e, o que é pior, pune de forma diferente certas camadas da população. As penas são mais severas para pessoas negras e migrantes, enquanto os crimes de corrupção cometidos por altos funcionários do Estado não são punidos, ou recebem punições leves e parciais. Em conseqüência tem-se, por parte da população em geral, descrença no sistema de justiça, medo da polícia e subnotificação de ocorrências como roubos e furtos;

\footnotetext{
${ }^{20}$ ADORNO, S. Exclusão Sócio-Econômica e Violência Urbana - NEV- USP; Preparado para o ciclo de Conferências "Sociedad sin Violência", promovido pelo PNUD - El Salvador. Disponível em: $<$ http:// www.nevusp.org.br/downloads/down77.zip>. Acesso em 21 nov 2006.
} 
$\checkmark$ desigualdade social e segregação urbana - conforme aponta o autor, a correlação entre crime e pobreza foi sustentada por diversos autores que viam o sistema capitalista de produção (promotor de exclusões inerentes ao seu funcionamento) como responsável pela ocorrência de crimes. Até hoje o senso comum relaciona diretamente criminalidade e pobreza, discriminando pessoas e grupos. Porém, o perfil social dos adolescentes que cometem infrações é semelhante ao perfil social da população jovem do município de São Paulo. De qualquer maneira, a desigualdade social produz desrespeito aos direitos humanos, sociais e políticos e intensifica as relações violentas e produtoras de violência. A desigualdade social, mas não a pobreza, funciona como propulsora da violência.

A violência extrema pode levar o indivíduo à morte, mas inúmeras outras formas de violência verbal ou não verbal, explícita ou escondida em atos aparentemente corriqueiros, porém opressores produzem efeitos no corpo e na vida de muitas pessoas, principalmente crianças e jovens. Vide capítulo apresentando as violências sofridas pelos jovens entrevistados para essa pesquisa.

Um estudo realizado pelo Núcleo de Violência da USP - Homicídios de crianças e jovens no Brasil: 1980 - 2002 (PERES, CARDIA e SANTOS. 2006) revela, enfatizando pesquisas anteriores que os jovens provenientes de famílias chefiadas por apenas uma pessoa têm maior risco de serem vítimas de violência fatal e outros tipos de violências. Isso porque suas famílias passam por privações econômicas, moram nas periferias desprovidas de recursos básicos como saúde, saneamento adequado, transporte e educação de qualidade.

Esses jovens vivem em condições de risco constante e são acompanhados por um menor número de adultos em condições de darem o suporte necessário para o seu crescimento emocional saudável e de protegê-los da exposição à violência. Apresentam também um vínculo frágil com a 
família, a escola, instituições profissionalizantes ou mesmo o mercado de trabalho.

Em busca de melhores condições de vida e trabalho, ou por não conseguirem arcar com os custos do aluguel, as constantes mudanças de moradia para outras localidades, também expõe os jovens a riscos. Esses seriam oriundos da necessidade de adaptação com novos grupos de pares, pela descoberta de onde é mais saudável a circulação no novo bairro e pela decifração dos códigos de conduta da região. (PERES, CARDIA, SANTOS. 2006. p.24)

Peres, Cardia e Santos (2006. p.36) levantam estudos que identificam os fatores de risco à vitimização, exposição e vulnerabilidade à violência. Entre eles destacam a facilidade na obtenção de armas de fogo, o abuso excessivo de álcool e drogas e a participação em antecedentes criminais graves. Os autores alertam sobre a influência da violência não fatal agressões físicas, sociais, morais, sexuais e psicológicas antecedendo desfechos fatais.

A pobreza não pode ser indicada como um fator determinante no desempenho da violência. Porém a desigualdade social e a segregação urbana são apontadas como fatores de risco, principalmente quando se percebe que, apesar das conquistas econômicas dos últimos anos, ainda é bastante desigual o acesso às instituições promotoras de bem estar social e aos direitos que deveriam ser iguais para todos. Também não é igual para todos a possibilidade de um emprego estável, o consumo de livros e revistas, o acesso a internet.

A pesquisa do Núcleo de violência da USP (PERES, CARDIA, SANTOS. 2006. p.39) aponta que:

Há fortes evidências de que o risco de ser vítima de homicídio é significativamente superior entre aqueles que habitam áreas, regiões ou bairros com déficits sociais e de infra-estrutura urbana [...] Tratase de bairros onde a infra-estrutura urbana é precária; as taxas de mortalidade infantil são elevadas; a ocupação do solo é irregular e, quase sempre, ilegal; e onde é flagrante a ausência de instituições públicas encarregadas de promover o bem-estar sobretudo acesso a lazer para crianças e adolescentes como também de instituições encarregadas de aplicar lei e ordem. A presença dessas agências é, 
não raro, associada aos fatos que denotam violência desmedida, repressão incontida e descaso de atendimento nos postos policiais.

Os dados a seguir indicam que a violência afeta diferentemente as pessoas segundo o sexo, a raça e a faixa etária. Isso indica que histórica e culturalmente alguns grupos sofrem com a violência mais que outros. A chance de um jovem negro, do sexo masculino, que tenha idade entre 15 e 24 anos sofrer violência fatal é muito maior que de qualquer outra pessoa.

\subsection{As crianças e adolescentes como vítimas de graves violações aos direitos humanos e violência fatal}

Entre os anos de 1980 e 2003, ocorreram graves violações de direitos humanos contra crianças e adolescentes no Brasil. Foram 5.718 vítimas. A maior parte foi vítima de execução sumária (53\%), ação com um total de 3.033 crianças e adolescentes entre 0 e 19 anos no País. 43\% foram vítimas de violência policial e $4 \%$ de linchamento. Supõe-se que em mais de $50 \%$ das graves violações dos direitos humanos contra crianças e adolescentes houve envolvimento policial. A grande maioria das vítimas era do sexo masculino em todos os tipos de violação analisados pela pesquisa. (PERES, CARDIA, SANTOS. 2006. p.175)

Pela pesquisa citada, quando consideradas as Instituições de Segurança, as delegacias constituem um ambiente privilegiado para a ocorrência de graves violações dos direitos humanos. Em segundo lugar, estão as Fundações para o Bem-estar do Menor (Febem) e os presídios/penitenciárias. (PERES, CARDIA, SANTOS. 2006. p.181)

68,5\% dos casos de violência policial ocorreram nas delegacias, seguidos pelas Febem(s) e presídios/penitenciárias. Já os linchamentos em locais fechados tiveram $88 \%$ dos casos em delegacias, estando em segundo e terceiro lugares o carro de polícia e Fóruns. (PERES, CARDIA, SANTOS. 2006. p.182) 
Pelos depoimentos dos quatro jovens entrevistados foi possível perceber seus direitos sendo desrespeitados por policiais nas ruas e dentro de delegacias, Febem(s) ou Fórum. (Vide capítulo "Os jovens entrevistados - o recorte da violência em suas vidas")

Em relação aos homicídios contra a população em geral, ou contra adolescentes e jovens, o Brasil não apresenta melhores condições das que foram apresentadas para as graves violações dos direitos humanos contra os jovens.

Segundo o Mapa da Violência 2006, em comparações internacionais com 84 países, o Brasil ocupava a $4^{\mathrm{a}}$ posição no ranking dos homicídios para a população em geral, com uma taxa de 27 para cada cem mil habitantes. Na faixa etária dos 15 aos 24 anos, o Brasil ocupava a $3^{\text {a }}$ colocação com uma taxa de 51,7 homicídios para cada cem mil jovens. (WAISELFISZ. 2006. p.65)

A taxa global de mortalidade da população brasileira caiu de $633 \mathrm{em}$ cem mil habitantes em 1980 para 572 em 2004. Já a taxa de mortalidade juvenil manteve-se praticamente inalterada ao longo do período e até teve um leve aumento, passando de 128 em 1980 para 130 em 2004.

Os motivos das mortes juvenis tiveram alterações aos longos dos anos. Há cinco décadas eram as epidemias e doenças infecciosas as principais causas das mortes nessa faixa etária. Em 2004 a maioria das mortes juvenis foi proporcionada por acidentes de trânsito e homicídios. (WAISELFISZ. 2006. p.21) No estado de São Paulo, no ano de 2004, $77 \%$ dos jovens morreram por causas externas, desses 43,9\% sofreram homicídio e 17,3\% morreram por acidentes com transportes. (WAISELFISZ. 2006. p.23)

A população jovem é a mais atingida no Brasil. Dos 15 aos 24 anos os homicídios atingem sua maior expressividade, principalmente na faixa etária dos 20 aos 24 anos de idade, com taxas em torno de 65 homicídios por 100 mil jovens. (WAISELFISZ. 2006. p.53)

A taxa de homicídios entre os jovens passou de 30,0 (em 100 mil jovens) em 1980 para 51,7 no ano 2004. Já a taxa de homicídios no restante da 
população (não jovem) permaneceu praticamente inalterada, passou de 21,3 em 100 mil para 20,8 no mesmo período.( WAISELFISZ. 2006. p. 73)

No Brasil os homicídios vitimam principalmente a população masculina. No ano de 2004, 92,1\% das mortes foram de homens. Entre os jovens a desvantagem masculina é ainda maior, pois apenas 6,3\% das mortes juvenis foram do sexo feminino. (WAISELFISZ. 2006. p.61)

A raça negra é a mais vitimizada, tanto para a população em geral como para a população jovem. A taxa de homicídio da população negra é bem superior à da população branca. Se na população branca a taxa em 2004 foi de 18,3 homicídios em 100 mil brancos, na população negra foi de 31,7 em 100 mil negros. Isso significa que a população negra teve $73,1 \%$ de vítimas de homicídio a mais do que a população branca. Entre os jovens o problema agrava-se ainda mais: os índices de vitimização elevam-se para 85,3\%. Isto é, a taxa de homicídios dos jovens negros é $85,3 \%$ superior à taxa dos jovens brancos. (WAISELFISZ. 2006. p.58-59)

Esses dados são assustadores e revelam que a população jovem brasileira vive em situação de risco. As elevadas taxas de violência a que os jovens, principalmente do sexo masculino e negro estão expostos mostra o descaso dos sucessivos governos brasileiros e autoridades responsáveis por elaborar e efetivar políticas públicas, que beneficiem os jovens residentes em bairros pobres ou nas periferias das grandes cidades, com baixa escolaridade e pouca qualificação profissional.

O estudo revela um ponto que pode ser considerado positivo: o número de homicídios sofreu um crescimento regular até o ano de 2003, com aumentos em torno de 5,1\% ao ano. Já em 2004, a tendência histórica reverteu-se de forma significativa. O número de homicídios caiu 5,2\% em relação a 2003, fato que pode ser atribuído às políticas de desarmamento desenvolvidas naquele ano. (WAISELFISZ. 2006. p.25) Essa queda no número de homicídios foi mais acentuada para a população jovem. Entre 2003 
e 2004 houve uma queda de 5,7\% no número de homicídios juvenis. Fator também atribuído a política de desarmamento ${ }^{21}$. (WAISELFISZ. 2006. p.29).

As mortes provocadas por causas externas não são as únicas consequiências da violência. Essa ocorre de inúmeras formas que não necessariamente levam a pessoa ao óbito. A vivência com situações violentas pode promover o recrudescimento e o desânimo frente às dificuldades da vida, o envolvimento no mundo do crime, a reprodução da violência sentida durante uma existência individual ou às humilhações sofridas por um grupo social ao longo da história.

Concordamos com o autor quando esse afirma que: “[...] nesse campo estamos sempre atuando diante das consequiências geradas por uma grande diversidade de fatores individuais, grupais, culturais, sociais, econômicos e políticos que se conjugam na explicação de cada situação concreta, fatores que, de forma isolada, não são fáceis de enfrentar ou de solucionar." (WAISELFISZ. 2006. p.159)

\subsection{Todos são vítimas: Os adolescentes vitimados pela violência transformam-se em autores de violência}

Como agente ativo ou como alvo da violência pode-se afirmar que os adolescentes e jovens brasileiros convivem e sofrem cotidianamente com a violência.

A percepção do problema da violência cometida por adolescentes vem se acentuando ao longo da última década. Atualmente a mídia destaca o delito praticado por adolescentes como se esses fossem verdadeiros algozes na escalada da criminalidade. O que não é verdade pelos dados apresentados a seguir. Veja também discussão no capítulo "A Mídia".

21 Foi promulgada, em dezembro de 2003, a Lei $\mathrm{n}^{\circ} 10.826$, conhecida como Estatuto do Desarmamento. O Decreto $\mathrm{n}^{\circ}$ 5.123, que regulamentou a lei, foi publicado em 2 de julho de 2004, começando a vigorar naquela data. Paralelamente, no mês de julho, teve início a campanha do desarmamento como política de entrega voluntária de armas de fogo por parte da população, com compensação monetária. 
"As características dos adolescentes (rebeldia, testagem da autoridade) favorecem a ligação feita pelo senso comum, altamente influenciado pela mídia, da periculosidade dos adolescentes." (TRASSI. 2006. p.165)

Em relação à violência praticada por adolescentes (12 a 18 anos incompletos) Sergio Adorno afirma, em pesquisa realizada para o município de São Paulo, que houve um discreto aumento da violência, se comparados dois períodos de pesquisa 1989-1991 e 1993-1996 22 e que esse índice acompanha o aumento da violência cometida pela população em geral. Porém, há que se ressaltar que o crescimento do crime violento entre os adolescentes é um pouco superior ao crescimento dos crimes violentos efetivados por adultos. (Ver gráfico 1). ${ }^{23}$ Segundo o mesmo autor, essa situação acompanha tendência internacional, verificada principalmente em países como Inglaterra e França.

\footnotetext{
${ }^{22}$ Apesar desses dados referirem-se à década de 90 , não há estudo semelhante para o período atual. Pesquisa realizada pelo Núcleo de Estudos da Violência da USP e relatada nos artigos: ADORNO, S. Criança e Adolescentes e a Violência Urbana. / ADORNO, S.; BORDINI, E. B. T.; LIMA, R. S. de. $\mathrm{O}$ adolescente e as mudanças na criminalidade urbana. São Paulo em Perspectiva. São Paulo, v. 13, n. 4, 1999. / ADORNO, S. Exclusão Sócio-Econômica e Violência Urbana - NEV- USP; Preparado para o ciclo de Conferências "Sociedad sin Violência", promovido pelo PNUD - El Salvador.

${ }^{23}$ Retirado de: ADORNO, S.; BORDINI, E. B. T.; LIMA, R. S. de. O adolescente e as mudanças na criminalidade urbana. São Paulo em Perspectiva. São Paulo, v. 13, n. 4, 1999
} 


\section{GRÁFICO 1}

Participação dos Crimes Violentos no Total de Ocorrências, segundo Tipo de População Município de Săo Paulo - 1988-1996

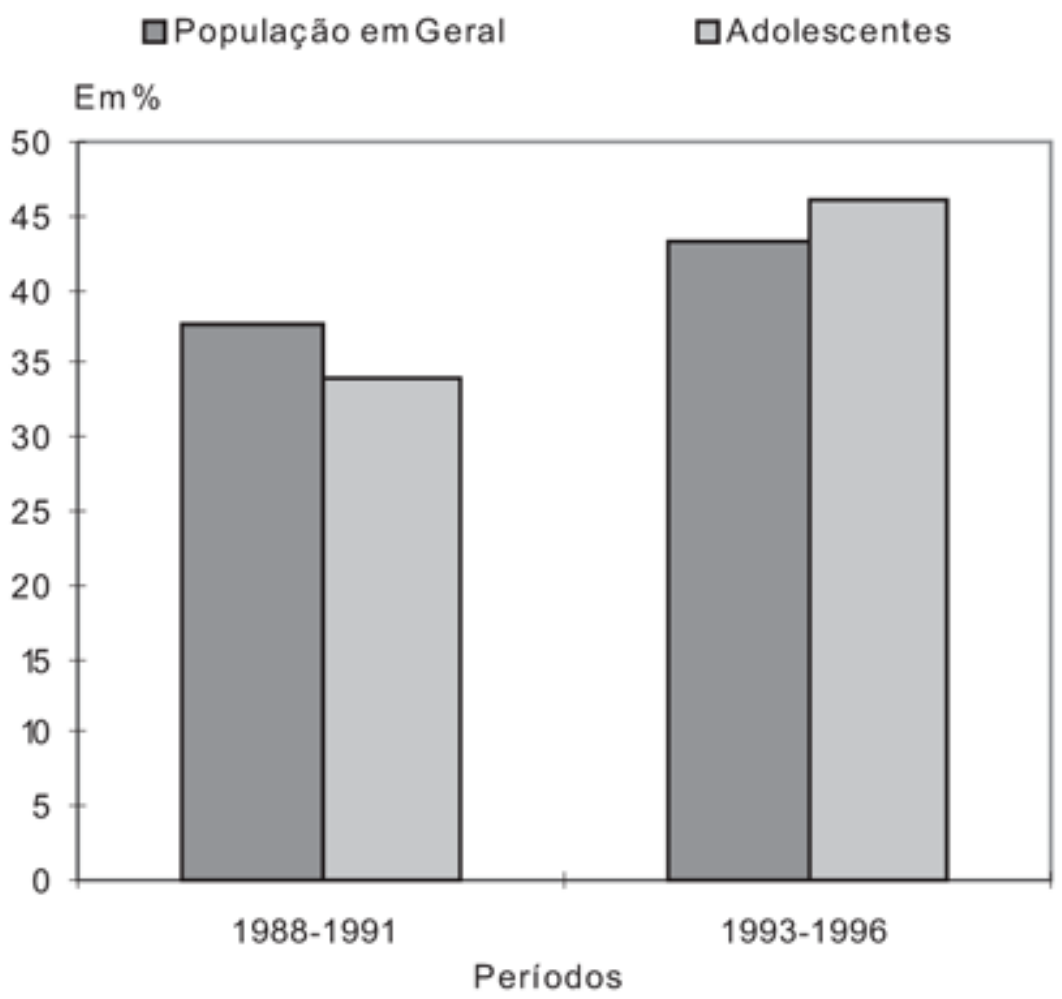

Fonte: Poder Judiciário/Varas Especiais da Infáncia e da Juventude da Capital; Convénio Fundação Sistema Estadual de Análise de Dados - Seade/Núcleo de Estudos da Violência NEV/USP.

Em relação à natureza das infrações cometidas, o perfil dos adolescentes não é diferente da população adulta. Analisando a natureza das infrações cometidas por adolescentes (após determinação da sentença pelo juiz nas Varas Especiais da Infância e Juventude), no município de São Paulo, (ver TABELA 2) ${ }^{24}$ percebe-se um ligeiro aumento no percentual de lesões corporais e roubos e diminuição na porcentagem de furtos, em relação aos

\footnotetext{
${ }^{24}$ Retirado de: ADORNO, S.; BORDINI, E. B. T.; LIMA, R. S. de. O adolescente e as mudanças na criminalidade urbana. São Paulo em Perspectiva. São Paulo, v. 13, n. 4, 1999
} 
dois períodos de pesquisa. Porém, não são mudanças estatisticamente relevantes.

Pela tabela, nota-se que a maioria das infrações cometidas por adolescentes encontra-se caracterizada como "contra o patrimônio", que somados perfizeram 51,1\% das infrações no período de 1993-1996.

A grande porcentagem de delitos classificados por "contra o patrimônio" revela as consequiências de uma sociedade centrada na propriedade privada, na aquisição de mercadorias para valorização pessoal e na multiplicação das possibilidades de objetos produzidos pela indústria.

Essa categoria de infração é considerada menos violenta por não afetar uma pessoa diretamente. As medidas socioeducativas decorrentes devem ser as de meio aberto.

Analisando as infrações cometidas 'contra o patrimônio', pode-se afirmar que estas estão, mesmo que não diretamente, afetando pessoas. As ‘coisas' subtraídas através de furto eram de 'alguém'. Há uma tentativa do adolescente em reparar uma privação sofrida na primeira infância. Tirar algo de 'alguém', uma pessoa que foi tirada dele em um período muito remoto na sua história pessoal.

Mas como afirma Winnicott (2005. p. 145) esse período de privação é posterior a um período inicial em que os cuidados foram satisfeitos, pois senão não seria possível a constituição de um indivíduo inteiro, não cindido. $O$ autor afirma também que a reação a essa privação, vinda através do ato infracional, pode ser considerada um pedido de socorro, um pedido para que a sociedade atue como reparadora do dano sofrido durante sua infância.

Na tabela 2 nota-se também um aumento nas infrações que envolvem tráfico, porte ou consumo de drogas. No primeiro período da pesquisa compreendia $0,70 \%$ das infrações cometidas, já no segundo período compreendia 7,20\% das infrações cometidas.

No grupo de ocorrências "contra a pessoa" nota-se que a taxa de homicídios, somada com a taxa de tentativa de homicídios é de 1,9\% das 
infrações cometidas. Ou seja, o percentual de crimes violentos cometidos por adolescentes foi bem pouco significativo. Bem diferente do que a mídia brasileira apresenta em suas colocações.

Tabela 2 - Distribuição das Ocorrências Policiais que Envolvem Adolescentes Infratores, Segundo a Natureza da Infração - Município de São Paulo - 1988-1996 (em \%)

\begin{tabular}{|c|c|c|}
\hline \multirow[t]{2}{*}{ Natureza } & \multicolumn{2}{|c|}{$\begin{array}{l}\text { Ocorrências } \\
\text { Policiais }\end{array}$} \\
\hline & $\begin{array}{c}1988- \\
1991 \\
\end{array}$ & $\begin{array}{c}1993- \\
1996 \\
\end{array}$ \\
\hline \multicolumn{3}{|l|}{ Contra a Pessoa } \\
\hline Homicídio & - & 1,3 \\
\hline Tentativa de Homicídio & - & 0,6 \\
\hline Seqüestro & 0,1 & 0,0 \\
\hline Lesão Corporal (Agressão) & 6,8 & 11,7 \\
\hline \multicolumn{3}{|l|}{ Contra o Patrimônio } \\
\hline Furto & 23,0 & 18,4 \\
\hline Tentativa de Furto & 6,9 & 7,6 \\
\hline Roubo & 15,6 & 19,0 \\
\hline Roubo seguido de morte (latrocínio) & 0,3 & 0,5 \\
\hline Tentativa de roubo & 2,3 & 4,2 \\
\hline Estelionato/tentativa & 1,4 & 1,4 \\
\hline \multicolumn{3}{|l|}{ Contra a Paz Pública } \\
\hline Membro de quadrilhas ou gangues & 0,2 & 0,2 \\
\hline \multicolumn{3}{|l|}{ Contra a Incolumidade Pública } \\
\hline Uso de drogas & - & 0,7 \\
\hline Porte de drogas & - & 3,6 \\
\hline Tráfico de drogas & 0,7 & 2,9 \\
\hline \multicolumn{3}{|l|}{ Contra os Costumes } \\
\hline Estupro/Tentativa & 0,6 & 0,7 \\
\hline Atentado violento ao pudor & - & 1,0 \\
\hline Outros atos sexuais & - & 0,5 \\
\hline \multicolumn{3}{|l|}{ Outras Ocorrências } \\
\hline Porte de Armas & 6,9 & 4,4 \\
\hline Dirigir sem carteira de habilitação & 9,4 & 6,5 \\
\hline Diversos & 17,8 & 14,8 \\
\hline Total & 100 & 100 \\
\hline
\end{tabular}

Fonte: Poder Judiciário/Varas Especiais da Infância e da Juventude da Capital; Convênio Fundação Sistema Estadual de Análise de Dados - SEAD/ Núcleo de Estudos de Violência NEV/USP 
Uma outra pesquisa, realizada pelo Instituto Latinoamericano das Nações Unidas para a Prevenção do Delito e Tratamento do Delinqüente ILANUD (ALMEIDA.; HOJDA.; KAHN ; SPOSATO. 2002) em que foram coletados dados do município de São Paulo, no período de junho de 2000 a abril de 2001, a partir de entrevistas com adolescentes acusados da autoria de atos infracionais, mas antes da determinação da sentença, mostrou caracterização semelhante a apresentada na pesquisa do NEV-USP

Os crimes "contra o patrimônio", ou seja, roubo e furto equivaliam a grande parte das acusações (45,8\%); os "crimes contra a vida" equivaliam a 10,4\% das acusações, sendo essa porcentagem distribuída entre 6,9\% lesão corporal, $2,1 \%$ ameaça e somente $1,4 \%$ homicídios.

Além destes, merecem destaque nos motivos dos encaminhamentos, o porte de arma (10,0\%), a direção sem habilitação $(7,9 \%)$ e porte e tráfico de drogas $10,4 \%$, porte $(5,2 \%)$ e tráfico de entorpecentes $(5,2 \%)$. Em $60 \%$ dos casos, segundo os entrevistados, a infração foi cometida com a presença de outras pessoas.

Pelas duas pesquisas apresentadas foi possível perceber que os atos infracionais cometidos por adolescentes não foram, em sua maioria, considerados como extremamente violentos. Ver discussão no capítulo "A Mídia".

Adorno, Bordini e Lima (1999) levantaram algumas hipóteses para esse aumento da violência praticada por adolescentes no município de São Paulo, mesmo que seguindo um aumento da violência em geral:

$\checkmark$ esse fenômeno segue uma tendência mundial;

$\checkmark$ seria efeito da chamada "onda jovem" - aumento da população jovem em relação a outras faixas etárias da população

$\checkmark$ influência da participação no crime organizado, principalmente o tráfico de drogas, que tem aliciado crianças e adolescentes para trabalharem;

$\checkmark$ maior inserção dos adolescentes em bandos e quadrilhas. 
Os autores afirmam também que as características dos adolescentes autores de ato infracional não se distinguem dos adolescentes do estrato socioeconômico ao qual pertencem. Afirma também que houve uma redução do número de adolescentes trabalhando e maior número de adolescentes envolvidos na criminalidade que estavam cursando o ensino médio. Isso pode ser um reflexo das políticas estaduais de educação (progressão continuada) e um envolvimento da classe média com a criminalidade.

Trassi (2006. p. 172) relata que na década de 90 vai se construindo um outro perfil do adolescente que comete ato infracional.

[...] Não é mais possível esconder que o adolescente de classe média está presente nas estatísticas; que só a escolaridade não é uma alternativa à prática do ato infracional, que o narcotráfico e o crime organizado arregimentam seus quadros entre adolescentes cada vez maus novos, alterando rapidamente os dados da pesquisa.

\subsection{Analisando a violência praticada e sofrida por adolescentes}

Pelas duas pesquisas apresentadas, verifica-se que os adolescentes não são os principais autores de crimes violentos.

Os jovens não são nem mais, nem menos violentos que a população em geral. Para cada três vítimas de homicídios tem-se um jovem que cometeu homicídio. (ADORNO. 2000. p. 108)

Porém, a mídia, a polícia e a opinião pública propõem, divulgam e manipulam outra forma de ver esses adolescentes. São tratados como bandidos extremamente violentos e perigosos. Esse sistema de representações precisa ser compreendido, explicitado e superado.

É importante perceber no debate entre punição, violência e crime o quanto estas práticas legais e ilegais são dotadas de historicidade, mesmo que comportem conteúdos dessocializadores, bárbaros e destruidores. São atravessadas pelas influências culturais e respondem também a necessidades sociais e econômicas. (SALES. 2004. p.166) 
Como foi visto anteriormente os jovens são mais vítimas de violência do que autores de violência. As mortes violentas ocorrem preferencialmente em bairros periféricos dos grandes centros urbanos. São bairros onde estão presentes cotidianamente diversas formas de violência. Bairros onde a densidade populacional é elevada, onde a infra-estrutura urbana é debilitada, com habitações precárias, acesso restrito a meios de transporte, não há ofertas públicas de saúde, não há oferta de empregos, onde a taxa de natalidade continua elevada, regiões em que há poucos ou inexistem espaços de cultura ou lazer. Mas, Adorno, Bordini e Lima (1999. p.10) afirmam também:

[...] tudo indica que tanto o crescimento da delinqüência juvenil mais propriamente da participação do crime violento nesse movimento - quanto a crescente vitimização de que são alvo os jovens não são fenômenos isolados, próprios de metrópoles com características sociais como as predominantes no município de São Paulo. Possivelmente, processos sociais mais amplos, até mesmo relacionados aos circuitos contemporâneos de internacionalização dos mercados e de integração de estruturas sociais em escala quase planetária, estejam na origem dos fenômenos e fatos observados.

Roman (2007. p. 36) afirma que "Esses jovens parecem, então, responder em ato ao que a sociedade lhes reserva como legado."

O mesmo autor propõe pensarmos a violência como uma organização de diversos aspectos, entre eles: "[...] o contexto sócio-econômico, relações comunitárias, características individuais, aspectos circunstanciais." E continua: "A vinculação entre os tráficos de armas e drogas e a falta de perspectiva das populações jovens, diante dos altos índices de desemprego e do abismo entre as classes sociais, contribuem sobremaneira para o incremento da violência urbana e criminalidade do país." (ROMAN. 2007. p. 36 )

Deve-se levar em conta, como já foi visto em capítulos anteriores o poder que o modo capitalista de existir tem sobre a coisificação das pessoas, sobre a necessidade contínua de consumo, sobre o impedimento do humano no homem. 
Devem ser levadas em conta as determinações históricas que estão presentes no contexto sócio-econômico e que ajudam a compreender a violência.

Assis (1999) acredita que as causas da violência cometida por adolescentes devam ser analisadas em três âmbitos que se inter-relacionam:

$\checkmark$ nível estrutural: onde devem ser analisadas as condições sociais - desigualdade social, desigualdade de oportunidades, falta de expectativas sociais, desestruturação das instituições públicas, facilidade de ingresso no crime organizado entre outros;

$\checkmark$ nível sócio-psicológico: as instituições responsáveis pelo desenvolvimento do adolescente (família, escola etc) com pouco controle sobre suas ações; a influência do grupo de pares;

$\checkmark$ nível individual: características da personalidade do indivíduo.

Se há um aumento na taxa de violência cometida por adolescentes, há impreterivelmente - a necessidade do conjunto da população debruçar-se sobre o tema para elaborar respostas para essas questões. Os jovens praticam violência, mas principalmente, sofrem-na cotidianamente.

[...] Em uma sociedade, como a brasileira, onde não se universalizou o modelo contratual de organização societária, onde não prevalece o reconhecimento do outro como sujeito de direitos, onde muitos se encontram à mercê de poucos, onde vige sem interditos acentuada assimetria no acesso a recursos bem como à sua distribuição, onde a vida de muitos não tem o mesmo valor e significado da vida de alguns, somente pode ser instituída a 'guerra de todos contra todos' como modo de funcionamento regular e normal. Daí que a violação de direitos humanos não seja menos escandalosa que a desigualdade social e o espectro de pobreza. (ADORNO, S. p.38) $)^{25}$

Apesar de parecer impossível a transformação/emancipação do indivíduo nessa sociedade, isso poderá acontecer pela "[....] instauração de processos de reflexividade da socialização e re-socialização como meios

\footnotetext{
25 ADORNO, S. Exclusão Sócio-Econômica e Violência Urbana - NEV- USP; Preparado para o ciclo de Conferências "Sociedad sin Violência", promovido pelo PNUD - El Salvador. Disponível em www.nevusp.org.br/downloads/down77.zip. Acessado em 21/11/2006.
} 
centrais catalisadores da autonomia individual e da emancipação coletiva, garantidoras e produtoras da crítica genuína" (ARDANS e TASSARA. 2003. p.29). Precisamos de uma cultura que respeite as diferenças, onde o elo social e a experiência sejam transmitidos genuinamente, que se possa ser o que se é, convivendo.

Quando, para essa pesquisa, voltei a conversar com jovens que conheci na Associação Novolhar, tive a impressão que conseguimos (alguns técnicos e alguns jovens) percorrer um caminho rumo à emancipação e a busca por direitos para todos.

A demissão....

E eu acho que ela julgou nisso, porque eu tinha passado pela Febem (....) Aí eles pegaram e me mandaram embora, eu peguei e falei (...) não vou assinar nada enquanto não falar com o pessoal do sindicato. (Lucas)

A análise.....

Tem que ver nessa forma ... acho que... é... a televisão tinha que decatar o menor, não só o menor, mas o preso mesmo, que quando sai, alguns tenta se recuperar, tenta procurar um trabalho, tenta mudar de vida e não.... as pessoas vira a cara pra eles, entendeu? As pessoas não olha do mesmo jeito que, tipo.... a eu não passei pela Febem, eu não passei pela cadeia, então eu tenho prioridade dentro do trabalho e aquele que passou, mesmo aceitando ele, fica com pé atrás, porque se some alguma coisa, vai culpar quem? Aquele que não teve passagem? Entendeu? Então eu acho assim, as pessoas deveriam olhar isso.... deveria dar prioridade pra.... o governo Lula deveria ver isso daí, deveria dar prioridade pra essas pessoas também que querem se recuperar, porque não é... não é fácil você pegar e ficar 2, 3 anos numa Febem ou ficar 5, 6 anos em uma cadeia e sair e o mundo estar a mesma coisa, você não consegue emprego nem nada, o que que você vai fazer? Vai ficar aqui passando fome, lógico que não! A pessoa vai querer... (Lucas)

A procura por trabalho....

... eu fui lá, entreguei o meu currículo (...) Aí eu estou procurando contato com ele... é... porque hoje em dia, se você não tiver um contato é bem difícil, né?(Lucas) 
O caminho a ser percorrido é longo e sonhado. Ele sabe os passos a dar, será que conseguirá? Meses depois da entrevista Lucas conseguiu um novo emprego em uma emissora de TV fechada.

O outro que nos faz dizer, o outro que nos ensina, nos choca, sacode a mesmice do senso comum, escancara as relações de poder, uma relação que não se faz fingir. Esses garotos tiveram sorte? Aproveitaram uma oportunidade? O que os fez escapar da violência? A palavra, o encontro com outro humano...

"Nas conversas, interessa a multiplicação dos pontos de vista e não o seu nivelamento: o encontro de pensamentos, não sua igualação." (GONÇALVES FILHO. 1995. p.10) É isso que se deve buscar na conversa com esses meninos.... A violência pede a palavra:

A violência, sempre sem palavras, dessignificada, pede palavras - quando a palavra não é possível, pede a visão (...) Apenas a palavra pode orientar a violência. E o exercício da palavra, ele mesmo, só é possível fora de toda violência. A violência e a palavra, lembra Hannah Arendt, excluem-se mutuamente. (GONÇALVES FILHO. 1995. p.106).

As infrações cometidas pelos adolescentes estão vinculadas a um contexto sócio-histórico. A entrada na criminalidade não é unideterminada socialmente, assim como não é unideterminada individualmente. Há condições históricas e individuais que constroem os caminhos para o desrespeito à propriedade privada ou a sua submissão. Roman ajuda a pensar:

[...] A idéia de um sujeito capaz de escolher entre vários caminhos deixa de explicitar que esses 'caminhos' são formas de existência social no contexto histórico em questão e que, portanto, são decorrentes de outros fenômenos sociais que o precederam. Da mesma forma, o sujeito que escolhe nasce sob determinações de um percurso traçado há gerações pelos representantes da classe social de que descende. Não há sujeitos sem condições históricas, ou "caminhos", que o pré-definam; não há caminhos que não sejam formas de relações sociais possíveis em certo contexto histórico e para certas classes ou indivíduos de acordo com a posição que ocupam nesse contexto, e, por fim, não há escolha que seja absoluta ou abstraída das determinações sociais que o constituem. (2007. p. 14) 
O fato de em uma mesma família haver irmãos, primos e demais indivíduos que foram criados sob as mesmas circunstâncias, que partilharam de uma história social comum e que, nem por isso, todos tenham cometido infrações, propõe a ampliação da discussão sobre os motivos que levam os adolescentes a cometerem infrações. A culpabilização do sujeito, ou da sua família, ou mesmo das condições culturais não devem ser consideradas unilateralmente, como propõe muitas matérias jornalísticas divulgadas na grande imprensa. Vide discussão no capítulo "A Mídia”.

Cada pessoa nasce em uma família, que está inserida em uma cultura, que possui uma história. Essa história familiar e comunitária está inserida em uma história de classe social, que por sua vez faz parte da história de um país, que tem relações com a história da humanidade. Quem faz a história são os homens nas suas interações cotidianas. Essa história individual se faz em reação, superposição, aceitação, negação etc, às suas possibilidades de classe. E então, dialeticamente, vai sendo parte da história da humanidade.

Cada ser humano é único e reage de forma diferente às possibilidades de existência. Cada um se apropria dessas possibilidades de maneira diferente para satisfação de suas necessidades. As ações individuais são atravessadas pelo contexto histórico social, mas carregam o ineditismo da ação, a recriação daquele indivíduo específico.

O ser humano se humaniza na relação com outros de sua espécie. É através do seu semelhante que ele aprende a estar no mundo e a partilhar uma cultura, os objetos, sua história.

[...] Em contato com o outro e mediado pelo outro que lhe concebe como potência e devir, o ser se apropria das objetivações humanas a que tem acesso em seu meio. Essas objetivações são produtos históricos: supõem a ação das gerações passadas, sintetizam no presente um percurso de constituição da humanidade e determinam a subjetivação, uma vez que não há sujeito sem objeto. (ROMAN. 2007. p. 114) 
Portanto, há que se ressaltar que o ser humano utiliza-se de objetos para construção da sua história e que sem estes não seria humano.

Em uma sociedade em que as relações são marcadas por interesses econômicos, as relações entre as pessoas são mediadas por coisas, tornam-se mercadorias. Na falta de objetos e objetivos compartilhados com a comunidade, com um conjunto da sociedade, há um impedimento da ação humana.

A não possibilidade de identificação com o humano no outro promove a violência.

"É preciso que se pense a construção da subjetividade em uma sociedade que tem, na violência, uma forma "natural" de agir." (FEFFERMANN. 2006. p. 311)

\subsection{A possibilidade do terror}

$\mathrm{O}$ século $\mathrm{XX}$ foi um período marcado por rápidas transformações nos costumes e nas ciências. O desenrolar de novas maneiras de construir conhecimento influenciaram os valores de convívio humano. As repostas às perguntas fundamentais da existência, que antes eram buscadas na observação e relação com a natureza, passaram a ser respondidas através da verificação de hipóteses. A dissolução de valores tradicionais e a valorização da busca da verdade científica transformaram a relação entre os homens.

Nesse século os homens mudaram o sentido da História que passou a ser contada, não a partir de fatos ocorridos, mas da criação de realidades que fizessem sentido em um determinado contexto ou para certo grupo - as ideologias.

Para Hanna Arendt (2004. p. 186) ideologias são:

[...] sistemas baseados numa única opinião suficientemente forte para atrair e persuadir um grupo de pessoas e bastante ampla para orientá-las nas experiências e situações da vida moderna. [...] A 
persuasão não é possível sem que o seu apelo corresponda às nossas experiências ou desejos ou [...] necessidades imediatas.

Portanto, o ser humano constrói explicações descoladas da história, mas que têm raízes nos anseios das pessoas para justificar atos de violência, discriminação e racismo.

As explicações eugênicas, poligenistas e darwinistas para as diferenças raciais entre as pessoas (ARENDT. 2004. pp. 207 e seguintes) são construções ideológicas, com bases aparentemente científicas, para justificar o racismo. E assim, justificam também o poder de uns sobre outros.

A escola, instituição responsável por fazer a ponte do mundo privado da casa para o mundo público dos adultos está em crise com o sentido de autoridade. O passado está desvalorizado e o futuro não é mais construído a partir das tradições. Como pensar autoridade e liberdade nesse contexto?

Hannah Arendt (1988) fala da crise da autoridade no mundo moderno e chama a atenção - "O sintoma mais significativo da crise [...] é ter ela se espalhado por áreas pré-políticas tais como a criação dos filhos e a educação, onde a autoridade no sentido mais lato sempre fora aceita como uma necessidade moral $[\ldots] "$

A autora afirma que autoridade exige obediência, que não deve ser confundida com o uso da coerção e da violência para se conseguir o que quer. Nesse caso, a autoridade fracassou. Por outro lado, a autoridade também não deve ser confundida com a persuasão que pede a argumentação. Para haver argumentação supõe-se uma relação de paridade entre as pessoas. A autoridade exige hierarquia e está alicerçada no passado e nas tradições. A autoridade " $[\ldots]$ deu ao mundo a permanência e a durabilidade de que os seres humanos necessitam precisamente por serem mortais." (ARENDT. 1988. p. 131)

A violência não pode ser confundida com autoridade nem deve ser tomada uma pela outra, apesar de, nos dois casos, serem maneiras de se conseguir o que se quer. Historicamente há inúmeros exemplos, como as 
guerras religiosas e os avanços da polícia nos morros cariocas, onde o uso da força é legitimado para a suposta garantia da paz.

A polícia, responsável por manter a ordem social na sociedade ocidental contemporânea, utiliza-se da violência para manter o relacionamento entre os grupos sociais com interesses distintos. O desrespeito aos adolescentes pobres da periferia de São Paulo mostra a quais interesses a polícia está defendendo - a propriedade privada e os donos do capital.

[...] o pensamento policial dominante parecia justificar o medo, fazendo-nos crer que o pobre é sempre suspeito e que os ladrões ou assassinos são "elementos" de que se deve proteger a sociedade. Este raciocínio epidemiológico e simplificador exprime e reforça a dificuldade de se encontrar o homem através da pobreza e, eventualmente, também através de seus crimes. E leva muito rapidamente ao recurso da repressão e do confinamento penitenciário [...] A psicologia do crime proletário e a psicologia da humilhação solicitam-se mutuamente. (GONÇALVES FILHO. 1995. p.159)

Assis (1999) relata em sua pesquisa que os jovens entrevistados sofreram agressões praticadas por policiais nas ruas e delegacias. A corrupção policial também foi relatada com freqüência pelos jovens entrevistados para esse trabalho. Além dos trechos abaixo há outros exemplos no capítulo "Os jovens entrevistados - o recorte da violência em suas vidas"

.... só que aí tinha uns policiais, uns policiais da rua, né? que às vezes eles tavam até com... a gente chamava eles de mão branca porque eles eram... eles já eram policiais disfarçados é... vestidos normal e vocês não... nem se ligavam que eram policiais e a gente chamava eles de mão branca, não, vou chegar nessa parte de porque que a gente chamava eles de mão branca, porque eles tinham... com eles tinham um acerto, assim tinha um acerto de você dar um dinheiro e você não ir preso e nessa vez que eu fui preso eu tentei ainda fazer acerto com os policiais... de eu ir pra casa e chegando em casa eu tinha dinheiro, foi desse próprio assalto que era os caras que estavam comigo, só que eles queriam que eu caguetasse, falasse quem estava comigo e nisso eu apanhei pra caramba, no meio da Avenida mesmo, mó multidão de gente no meio da Av. Paulista. (Alex)

Bom, nesse dia eu apanhei bastante que era pra eu levar os policiais até minha casa, que era pra caguetar as pessoas que estavam comigo, mas eu resisti a..., a toda a.... a toda essa pressão de apanhar, de me baterem, torturar de uma certa maneira e não levei ninguém preso junto comigo... (Alex) 
Daí um foi embora porque os polícia conhecia ele e liberou ele por causa que ele trabalhava num negócio.... num bar, numa lanchonete em S., que o dono de lá era policial também e daí como eles conhecia, soltaram ele.

[Ele pagou?] Não pagou nada, quer dizer falaram "quando nós for lá vocês vão liberar umas feijoadas pra nós". "Não, pode ir que está na minha conta!” Aí soltou ele. (Douglas)

[Tem acordo entre esse pessoal do Comando e os juízes?] Ah tem, tem, tem.... o juiz hoje em dia... é.... se você tiver dinheiro mesmo, você sai da cadeia.... se você não tiver....

(...)

Chegou lá os ladrões ofereceram um dinheiro para liberar eles, 50 mil reais, daí falou não, por esse preço nós tira a arma e tira as mercadorias, fica como tentativa de 155, daí firmeza, fizeram um acordo, daí chegou na 72 e ele falou "e aí, tem como fazer um acerto pra soltar nós?" Daí o carcereiro, o policial lá falou "é o seguinte, se você tiver 200 mil aí, você sai agora", daí ele falou "eh, cê tá é tirando, se quiser eu te dou 200 real, já tô fichado mesmo, vou ficar como fugitivo", daí ele falou "não, cê me dá 70 mil e você vai embora agora, já te dou, pego até o telefone lá na frente pra você ligar pro seu advogado vir trazer o dinheiro", daí não sei o que foi lá que daí não soltaram o dinheiro. (Douglas)

O contato com as agências de controle da ordem pública resulta, não raro, em constrangimentos e intimidações de várias ordens, que compreendem a corrupção, maus-tratos, tortura, a fraude de testemunhas e de provas, a imputação injusta de delitos, o uso de outras crianças e de adultos delinqüentes como forma de intimidação. (ADORNO. 1993. p.205)

O policial quer prender a todo custo, é ele quem decide o destino dos que são presos, aliás, é ele quem decide quem vai preso. Há aí superposição de poderes, há a onipotência do sujeito que pensa estar acima da legislação que garante um julgamento a qualquer acusado. Pior que tudo isso é que a sociedade brasileira valoriza e reforça a postura violenta da polícia. A violência institucionalizada é validada para apoiar certos interesses e para superar "conflitos sociais". Conflitos muitas vezes criados por condições econômicas precárias e por desigualdade na distribuição de renda.

Os policiais acham que são juizes, mas a gente sabe que tem o direito de passar por processo e ser julgado pelo juiz, a gente sabe desse direito. Apanhei muito, mas eles não são juízes... (conversa informal com um ex-presidiário - vide Apresentação) 
"Os policiais agem ou por força das armas ou da corrupção. Imprime-se uma relação de medo diante dessa inconcebível brutalidade. Está-se diante de uma desordem, ou de uma ordem que garante a manutenção do sistema vigente.” (FEFFERMANN. 2006. p. 291)

$\mathrm{Na}$ Febem ou nas instituições responsáveis pelo cumprimento da medida socioeducativa de internação para adolescentes que cometeram atos infracionais, o uso da força é usado no intuito de se obter autoridade. Mas como vimos na definição acima, SE HÁ VIOLÊNCIA, NÃO HÁ AUTORIDADE.

Pesquisa realizada por Roman (2007) relatou que os adolescentes sofreram humilhações constantes e castigos físicos quando estavam sob a tutela do Estado em delegacias ou cumprindo uma medida socioeducativa na Febem-SP.

Assim foram também as experiências de Alex e Lucas:

Eles falam que a Febem resgata (...) mas ali tem... fica totalmente no mundo do crime (...) o trato da pessoa, o trato do ser humano, entendeu? Eles não tratam a gente bem, tratam a gente mal.... (Lucas)

lá tinha seus funcionários.... a gente teve.... acho que o momento mais crítico assim na Febem... nessa época, teve outros né, de apanhar...de não sei que, mas teve uma rebelião que a gente quebrou tudo e a Choque entrou, a gente teve que entrar pra dentro dos barracos antes que ela... que a Choque começasse a jogar gás, gás lacrimogêneo e começar a bater, só que nisso os barraco, os barracos ficaram aberto e a gente de coruja e ficaram cada guard...um guarda.... dois guardas da Choque em cada barraco, assim... eram... 6 barracos, cabiam 12, 12 menores em cada barraco que eram 6 por $12 \ldots$ que dava $68 . .$. né? (Alex)

Para Arendt, (1988. p. 144) "A autoridade implica uma obediência na qual os homens retém sua liberdade [...]", sua potencialidade de espontaneidade, sua capacidade de iniciar algo novo.

Hanna Arendt em Entre o Passado e o Futuro (1988) faz uma breve explanação sobre possíveis formas de governo. Através dele um povo garante a existência da sua nação e luta por manter certa identidade. 
O governo autoritário segue leis que, como uma força externa, legitima seus atos. Uma figura na forma da pirâmide pode representar o governo autoritário. A autoridade e o poder se filtram do topo para a base de forma que os postos acima sempre exercem poder sobre os que estão abaixo. Da base para o topo há linhas convergentes que se juntam em uma fonte de poder no alto. Essa forma de governo autoritário, "com sua estrutura hierárquica, é a mais igualitária de todas as formas, ela incorpora a desigualdade e a distinção como princípios ubíquos."(ARENDT. 1988. p. 169) Os regimes autoritários propõem restrição de liberdade.

Nas tiranias e ditaduras há abolição da liberdade política. O tirano governa por sua própria vontade, como se fosse uma luta de um contra todos, onde todos esses outros, oprimidos, são iguais entre si. Para manter uma forma de governo como essa, o uso da violência é necessária para deixar os membros da população desintegrados e isolados.

Nos regimes totalitários há eliminação de toda a liberdade e espontaneidade com desaparecimento das autoridades tradicionalmente constituídas. No centro de todos está um líder. Seu poder emana do centro para a periferia de um sistema totalmente integrado. "A vantagem desse sistema é que o movimento proporciona a cada um de seus níveis, mesmo sob condições de governo totalitário, a ficção de um mundo normal [...]" (ARENDT. 1988. p.136)

A partir dessas definições passei a tentar compreender qual tipo de governo se estabelece na Febem. Será que isso é possível? Pois essa é uma instituição legitimada pelo governo democrático.... Mas que democracia é essa?

Com a impressão de que aquela instituição era um "mundo à parte" de tão absurda que foram as experiências vivenciadas por mim mesma e, pelos relatos dos adolescentes e jovens que conheci, as deles também não foram diferentes, tive a ousadia de pensá-la como representação de uma mistura de 
totalitarismo com autoritarismo. $\mathrm{O}$ autoritarismo da aparente hierarquia, o totalitarismo do líder central e do terror estabelecido.

Quem governa a Febem são representantes da esfera estadual do governo, na figura de um presidente da instituição. Há uma aparente hierarquia de poderes, pois os cargos superiores possuem poder e influência sobre as decisões tomadas abaixo deles. Essas decisões são respeitadas, mesmo que as pessoas individualmente não concordem com elas, pela necessidade dos funcionários garantirem seus empregos. O controle na instituição é obtido pela necessidade de sobrevivência. A rotatividade de funcionários é intensa.

$\mathrm{Na}$ prática, quem comanda são os funcionários que estão no último degrau da hierarquia e que deveriam cuidar da segurança física e bem estar emocional dos adolescentes. Eles é que disseminam o terror.

Apesar de existirem leis e regras legalmente constituídas (ECA, Direitos Humanos, Constituição Federal) que regulariam a instituição, o poder é conseguido a partir do medo e da violência explícita e camuflada.

Com a missão de "Executar, direta ou indiretamente, as medidas socioeducativas com eficiência, eficácia e efetividade, garantindo os direitos previstos em lei e contribuindo para o retorno do adolescente ao convívio social como protagonista de sua história." e tendo como valores a justiça, a ética e o respeito ao ser humano ${ }^{26}$ a instituição afirma estar de acordo com leis federais e internacionais, mas na prática vem desrespeitando-as sistematicamente.

Debaixo de muito terror a liberdade e espontaneidade de funcionários e internos desapareceram. A possibilidade de ação humana fica abortada e impedida.

Em períodos de crise como nas grandes rebeliões, quem comanda as pequenas partes (unidades) dessa enorme instituição são os próprios adolescentes. Nessas ocasiões eles são tiranos que querem impor sua própria

\footnotetext{
${ }^{26}$ Informações retiradas do site da Fundação Casa, nome atual da Febem- SP. www.casa.sp.gov.br acessado em 30 outubro de 2007.
} 
vontade. Além de serem visivelmente cruéis. Para eles todos são iguais, podendo ser um dos adolescentes ou funcionários, sem direitos, oprimidos. A violência é a arma para se conseguir a ordem desejada e a reivindicação de direitos. As rebeliões têm uma multiplicidade de sentidos e atravessamentos.

.. eu tinha acabado de chegar, né? E aí os caras... na rebelião os caras pegaram esse cara.. que ele era... ele era estrupador e... tava no seguro e quando virou a casa, que era a rebelião, né, quando o motim aconteceu, aí os caras pegaram ele, colocaram em cima de um colchão assim ó e pegaram, a gente chamava de Highlander, que era umas naifas, que eram uns, umas barras de ferro, que a gente apontava no chão mesmo e aí virava uma lança, com a ponta de lança e atravessou no coração do cara de uma tal maneira... que aí eles fizeram... meio que uma churrasqueira com carne do cara, que botaram de atravessado ele, ele assim é... na Highlander, na... nessa barra de ferro, colocaram entre as grades... uma grade e outra grade de um portão aberto assim, era um portão aberto e um fechado, colocaram entre ele, colocaram o colchão embaixo, tacaram fogo nele, deixaram ele queimar e aí arrancaram o pescoço, arrancaram o pescoço dele com....acho que era um... um... facão bem afiado, só que era também de barra de ferro, só que era aquela barra de ferro mais... mais fina e aí afiava, né, e arrancaram o pescoço dele assim e ele ficou com a cabeça assim e jorrando sangue, já tava morto... já tava morto e aí ele começou a queimar, queimar e aí depois é... pegaram o corpo dele e queimaram e jogaram pra Choque, e jogaram pros funcionários lá, nisso tinha um monte de refém lá que era os funcionários e tinha os Seguro que era refém também nosso.....bom, mas isso foi só... algum, algumas coisas que ficaram assim na cabeça, é marcado, gravado que assim é... não... é inesquecível, mas tem outras coisas também que eu passei muito, que eram também piores.... (Alex)

Vicentin (2005. p. 78 e seguintes) expressa as inúmeras possibilidades que uma rebelião pode significar. As rebeliões reivindicam direitos e podem ocorrer por questões políticas e econômicas como a disputa de poder entre facções diferentes, por questões institucionais como uma disputa de poder interna entre funcionários, por questões intersubjetivas dos internos como forma de minimizar as tensões vividas cotidianamente e/ou para obtenção de prestígio pessoal ou privilégios.

As rebeliões fazem os jovens aparecerem, tornam-se visíveis de maneira perversa. A rebelião é "[...] o esforço de "presentificar-se" pela sensação de não serem nada, ninguém[...]" (VICENTIN. 2005. p. 67). Elas são atos de violência denotando o abuso da violência. A visibilidade dos jovens em uma rebelião torna-se necessária para que os invisíveis (crianças e 
adolescentes pobres), descartados e descartáveis pelo sistema capitalista de produção sejam tomados como sujeitos de direitos. Direitos esses que já se fazem presentes na legislação brasileira (ECA) e que não vem sendo cumprido pelo conjunto da sociedade.

A rebelião é, então, insurgência corporal quando os limites e os constrangimentos (sejam eles as humilhações, os espancamentos ou a necessidade de sair do isolamento, de falar) tornam-se intoleráveis. Ela é ponto-limite na expressão de conflitos cuja solução não se pode contar com formas institucionalizadas de negociação política ou jurídica legítimas. (VICENTIN. 2005. p. 105)

A rebelião como forma de ser ouvido, de gritar.... Os jovens precisam falar e serem ouvidos!

Vicentin (2005.p.193) acredita que “[...] se houver formas democráticas, participativas e mais justas de convívio e portanto de pacificação social, estas [as rebeliões] cessarão".

As rebeliões dos adolescentes e adultos encarcerados buscam, mesmo que com o uso explícito da violência, restaurar sua condição de sujeito, romper a sequiência infinita de humilhações.

que nem lá no Belém que nós foi virar alguma coisa, a cadeia, que nem nós viramos na 39 também, nós avisava é... tinha funcionário que nós falava, "ó, amanhã é seu plantão, nem aparece que amanhã nós vamos virar a cadeia e dependendo quem tiver aqui nós vamos grudar". [O pessoal que vocês achavam bacana vocês avisavam?] Isso, nós avisava, pra não ter nada, nada acontecer com eles, né? Tem funcionários ali que trata você como gente, agora tem outros que trata você pior do que um cachorro, do que um bicho.....nós vamos virar a cadeia, nós vamos parar, não vamos pegar bóia, comida, não vamos pegar nada, não vamos receber mais visitas, aquele negócio, a cadeia está parada, não sai fora, que nem aconteceu esses tempos, então é sempre assim, é sempre atrás de algum, algum benefício pros próprios pessoal que estão presos, uma reivindicação, entendeu? Não apoiando porque eles também fazem bastante, muitas coisas erradas..... (Douglas)

o PCC é isso daí, então lá eles roubam, fazem a atividade deles, como todo ladrão, mas está ali pra.... procurar direitos. Hoje em dia através do PCC que hoje tem muitas coisas dentro da cadeia que não tinha antigamente, o direito de ter visita íntima, de ter uma alimentação mais adequada, é.... essas coisas... você não ser mais agredido pelo choque, é.... coisa que antigamente era feito é.... através do jeito deles que é o jeito errado, né? Mas é o único jeito pra gente chamar a atenção da reportagem pra situação da população... que nem esses ataques, esses negócio, foi o modo de chamar 
a atenção, de parar São Paulo pra ver uma coisa, colocaram... mandaram pessoas colocar placas na rua, tudo, pra explicar pra população que não era pra população, nós estava matando polícia, polícia, carcereiro que estavam realmente prejudicando nós, que nem... carcereiro que bate em nós lá dentro, machuca nós lá dentro e nós não pode fazer nada com eles lá dentro, então tem pessoas do Comando que já faz isso aqui fora, primos leal, pessoas assim... é um modo de chamar a atenção.. pra ver o processo, tá entrando com algum recurso pra lá pra dentro... é direito de entrar visita que não seja familiar, de..... entrar uma alimentação mais adequada pra nós, é...

Douglas)

Não podemos nos enganar, as Febem(s) e cadeias são frutos dos desejos e anseios de uma parcela significativa da população. Sua mudança vem sendo solicitada, reivindicada e conquistada lentamente por setores de defesa dos direitos das crianças e adolescentes da sociedade brasileira.

Será que posso falar que nos morros do RJ há emprego do terror? E na Febem de SP? A realidade aterrorizante que considera todos como seres humanos da pior espécie, bandidos cruéis e perversos e que age indiscriminadamente, sempre com violência para a suposta manutenção da "ordem social" não pode ser considerado como instrumento do terror para dar realidade a "mentiras utilitárias" (ARENDT. 2004 p. 390)? Com certeza não posso comparar ao terror utilizado pelo regime totalitário ou a existência das propagandas totalitárias que levaram as massas a acreditarem em eventos construídos com coerência e perversidade, nem mesmo aos campos de concentração. Mas acredito que sejam sim uma forma de "terror" que impede a humanização dos homens.

Hanna Arendt (2004. p. 511) afirma que: "As soluções totalitárias podem muito bem sobreviver à queda dos regimes totalitários sob a forma de forte tentação que surgirá sempre que pareça impossível aliviar a miséria política, social ou econômica de um modo digno do homem."; e que o governo totalitário, além de promover o isolamento político das pessoas para destruir a vida pública, condena os homens à solidão destruindo também a esfera privada. "[...] Baseia-se na solidão, na experiência de não pertencer ao mundo, que é uma das mais radicais e desesperadas experiências que o homem pode ter." (ARENDT. 2004. p.527); A partir dessas considerações a existência de 
Febem(s) e os assassinatos em massa realizados pela polícia nos morros cariocas dão o que pensar....

A violência institucionalizada esteve e está presente ao longo de toda a história do Brasil, inclusive nos dias de hoje. O golpe de 1964 e a vivência da ditadura exacerbaram o autoritarismo e a violência exercida pelo Estado para conter os cidadãos e impor o que esse mesmo Estado, impregnado de uma determinada visão de mundo, acreditava ser "a ordem".

No terreno da criminalidade comum, os efeitos desse amplo processo de reordenação das relações sociais e políticas em torno do regime autoritário não se fizeram por esperar. (...) Nas delegacias e distritos policiais, torturas e maus tratos contra presos, suspeitos de práticas de crimes, constituía rotina nas investigações policiais. (...) Paradoxalmente, no curso do processo de transição democrática, as práticas violentas e arbitrárias de contenção do crime tenderam a acentuar-se. (ADORNO. 2002 p.6).

E os adolescentes continuam a subir nos muros das Febem(s) para serem notados.... E a violência na obtenção de depoimentos continuam nas delegacias.... E o desrespeito aos direitos humanos são visíveis quando se encarceram adolescentes com presos adultos em celas comuns.... 
Capítulo 9 - AS LEIS 


\section{AS LEIS}

[...] A estabilidade das leis corresponde ao constante movimento de todas as coisas humanas, um movimento que jamais pode cessar enquanto os homens nasçam ou morram. As leis circunscrevem cada novo começo e, ao mesmo tempo, asseguram a sua liberdade de movimento, a potencialidade de algo inteiramente novo e imprevisível; os limites das leis positivas são para a existência política do homem o que a memória é para a sua existência histórica: garantem a preexistência de um mundo comum, a realidade de certa continuidade que transcende a duração individual de cada geração, absorve todas as novas origens e delas se alimenta. (ARENDT. 2004. p. 517)

Trassi (2006. pp. 219-220) afirma que desde o século XVI já havia registros de crianças abandonadas na história do Brasil. Eram as crianças portuguesas órfãs que, trazidas pelos jesuítas, serviam como chamariz para atrair as crianças indígenas para a catequese.

No século XVII encontram-se relatos da existência de crianças enjeitadas, filhos de portugueses com as índias brasileiras, ou com as mulheres negras vindas da África. Essas crianças eram recolhidas em lugares denominados "Casas dos Muchachos", que tinham o objetivo de educar as crianças dentro dos preceitos da Igreja católica. (Couto e Melo. 1998. f.1)

No século XVIII os abandonados eram colocados na Roda dos Expostos para serem criados por famílias substitutas. As condições econômicas e os preceitos morais da época foram os principais responsáveis pela existência dessas crianças abandonadas. Eram crianças filhos de famílias pobres ou filhos nascidos fora do casamento de famílias ricas.

O mecanismo de funcionamento da Roda fazia com que a identidade do depositante ficasse preservada, o que aumentou consideravelmente o número de abandonados. Muitas morriam, outras eram entregues às famílias que recebiam dinheiro do Estado para o cuidado da criança até que essa completasse 8 ou 9 anos. A partir daí eram encaminhadas para fazendas ou asilos de caridade. (Couto e Melo. 1998. f.2) 
No século XIX as crônicas referem-se a meninos que viviam em bandos e cometiam delitos nas ruas do Rio de Janeiro. A explosão demográfica e as precárias condições de vida no grande centro urbano levaram um elevado número de pessoas a sobreviver de esmolas e mendicância no centro da capital. Naquela época, perambular pelas ruas era passível de levar o indivíduo à prisão. "[...] uma grande parte da população urbana, principalmente a fadada à pobreza, passou a ser depositada nas "Casas de Correção" como eram chamados os presídios na época”. (Couto e Melo. 1998. f.3) As crianças e adolescentes eram encaminhados para os mesmos locais dos adultos.

Roman (2007. p. 40) citando Bala e Bromwich (2002), afirma que o primeiro sistema de justiça juvenil diferenciado do sistema adulto foi estabelecido nos EUA no final do século XIX. Suas características eram, entre outras: processos judiciários informais e privativos; sentenças indeterminadas - o jovem ficava sob custódia até ser considerado reabilitado; discricionaridade, ou seja, não regulamentação processual; promoção do bemestar da criança que deveria ser "salva" da vida do crime etc.

Eram medidas pautadas no preconceito étnico, discriminatório em relação à pobreza, paternalista e violadoras de direitos. O sistema americano foi modelo para outros países ao redor do mundo.

O Código Penal brasileiro de 1890 cogitou prisões especiais para menores de 18 anos, mas em 1910 ainda não havia sido construído nenhum estabelecimento para esse fim. (TRASSI. 2006. p. 220)

A primeira participação, ainda incipiente, do Estado brasileiro em relação à infância e juventude foi a criação do "Instituto de Menores" na "Casa de Correção da Corte". Essa instituição durou de 1861 a 1865 e destinava-se aos abandonados, aos que fossem apreendidos pela polícia por "vagabundagem", "aos que por má índole não podiam ser corrigidos por seus pais ou tutores", ou os que "não puderem receber uma educação conveniente e apropriada em outro lugar". (Couto e Melo. 1998.f.3) Ou seja, o Estado passou a tutelar a pobreza, como se essa fosse um crime passível de encarceramento. 
A educação moral e religiosa era o objetivo do instituto, como se as famílias pobres não fossem capazes de educar seus filhos.

Evaristo de Moraes em "Criminalidade da infância e da adolescência" (1927), apoiado por diversos autores europeus e americanos, afirma que as condições para a entrada na criminalidade eram de ordem individual e social. A hereditariedade de aspectos físicos, psicológicos e morais afetariam os descendentes. O meio social em que fossem criados poderia levar "mentes fracas" para a delinqüência.

$\mathrm{O}$ autor considera que o alcoolismo dos pais, as transformações da puberdade com o desejo sexual conseqüente poderiam levar a formas psicopáticas de existir. (1927. p. 15)

Outros aspectos levantados por Evaristo de Moraes para a entrada de adolescentes na criminalidade seriam: a desorganização e a má influência moral da família (1927. p. 28); a necessidade dos pais trabalharem fora e deixarem as crianças sob os cuidados de outras pessoas (1927. p. 32); as moradias coletivas ou extremamente pequenas em que pais e filhos dividiam o mesmo cômodo (1927. p. 33)

Com idéias higienistas, a elite pensante da época propunha a "limpeza" dos hábitos e dos espaços urbanos de circulação dos pobres para melhoria da raça. Essas idéias visavam evitar que pessoas ditas "sem moral" pela elite do país, ou viciados em álcool, ou operários que precisavam trabalhar para tentar sustentar suas famílias cuidassem de seus filhos.

No início do século XX os juristas e os médicos, apoiados na idéia de limpeza da raça, passaram a ser responsáveis pela determinação do tratamento dado aos mais pobres. A naturalização da pobreza e a patologização da delinquiência reinavam nos discursos científicos e na prática de tais profissionais.

[...] Na medida em que as teorias científicas da época afirmavam que os comportamentos desviados eram resultado do somatório de características herdadas geneticamente e de hábitos apreendidos no meio social, a internação das crianças em instituições era imprescindível para que se alcançasse a melhoria da "raça 
brasileira", desde que estas se tornassem locais de educação e formação moral. (Couto e Melo. 1998.f. 5)

Essas idéias favoreceram a leitura de que as famílias eram as responsáveis pela situação precária em que se encontrava a infância da época, não levando em consideração que as condições social e econômica do Brasil e a falta de políticas públicas influenciavam tal condição. Essa forma de pensar ainda perpassa o imaginário social para justificar a entrada de crianças e jovens pobres na criminalidade. Aliás, a situação precária de inúmeras crianças e jovens brasileiros, ainda hoje é vista por muitos como sendo responsabilidade dos indivíduos ou de suas famílias.

No século XX as idéias eugênicas de purificação da raça foram trazidas para o Brasil. Uma política voltada às crianças e jovens, considerados responsáveis pelo futuro da nação, foi elaborada. A prática de exercícios físicos, o ensino profissionalizante e a educação moral e cívica eram atividades que deveriam promover, nos mais pobres, hábitos de higiene 'corporal' e 'moral', de acordo com os preceitos determinados pela classe economicamente favorecida.

O Código de Menores de 1927 ou Código Melo Matos como também ficou conhecido foi o instrumento que passou a lidar com jovens de forma diferenciada dos adultos. Tratava dos que eram considerados abandonados, os "abandonados morais", os que não tinham condições financeiras e os que tinham cometido um ato infracional.

Esse instrumento era discriminatório em relação à pobreza, apoiava o disciplinamento dos corpos e não respeitava os direitos civis e sociais. Os pais pobres podiam perder o direito de cuidarem de seus filhos por não terem dinheiro. O juiz poderia encaminhar as crianças ou adolescentes nessas condições para instituições de internação, afastando-os do convívio familiar. Essa prática visava afastar as crianças de um meio ambiente, que se acreditava na época, poderia levá-las à criminalidade. Infelizmente esse pensamento perpassa os discursos de muitos até hoje. 
O Código de Menores de 1927 estipulava que as medidas de 'proteção' e 'amparo' destinavam-se aos menores de 18 anos que estivessem privados de condições mínimas de existência, sofrendo castigos excessivos ou maus-tratos. Para as crianças e adolescentes abandonados e os que cometiam delitos, a proposta era de confinamento, repressão, disciplina e assistencialismo. As crianças deveriam ser afastadas de sua família de origem para serem 'tratadas' em instituições fechadas.

O Código de 1927 segue esses preceitos e pontua um termo que será utilizado até hoje e que criou um rótulo nas crianças e adolescentes pobres do país: menor $^{27}$. Menores eram as crianças e adolescentes que estivessem privados das condições para o seu desenvolvimento físico e moral. Essas categorias eram firmadas pela elite econômica do país para diferenciar os filhos de negros e pobres dos filhos da camada rica da população. As crianças e adolescentes pobres passaram a receber esse termo de forma pejorativa.

Em 1941 o governo brasileiro criou o Serviço de Assistência ao Menor - SAM. Tinha o objetivo de organizar as instituições públicas ou particulares no atendimento à infância. O Estado, seguindo as determinações de juristas e médicos, aciona o seu poder para evitar que as famílias pobres "produzam a delinqüência", conforme a ciência da época acreditava. O Juizado de Menores destinou grande número de crianças e adolescentes pobres aos estabelecimentos correcionais.

O SAM durou 23 anos e com o golpe militar de 1964 os militares criaram a Fundação Nacional para o Bem Estar do Menor (FUNABEM), a qual estariam ligadas, posteriormente, as Febem(s) estaduais.

\footnotetext{
${ }^{27}$ Conforme afirma Adorno (1993. pp. 183-184) o termo menor foi cunhado no Brasil pela medicina legal e reconhecido pelo direito público para separar a população em “[...] responsáveis e irresponsáveis, segundo o critério do discernimento moral e do desenvolvimento psicológico [...] Trata-se da criança cuja existência social e pessoal é reduzida à condição de menoridade, passível, por conseguinte, da intervenção "saneadora" das instituições policiais de repressão e das instituições de assistência e de reparação social." Para maiores detalhes sobre essa questão ver: Lopes, J.S. Escola na FEBEM-SP: em busca do significado.São Paulo. 2006. 149p. Dissertação (mestrado). Instituto de Psicologia. Universidade de São Paulo e Lodoño, F. T. A origem do conceito menor in Priore, M. D. (org) História da criança no Brasil. São Paulo: Editora Contexto. 1991.
} 
As características dessas novas instituições eram semelhantes às do SAM: as famílias pobres continuavam sendo responsabilizadas pelos problemas da infância e adolescência. Eles eram considerados uma doença que necessitava de tratamento. As FUNABEMs deveriam '[...] 'guardar' as crianças e adolescentes para que os mesmos não viessem a cometer atos antisociais e 'reeducar' aqueles que já tivessem praticado algum desses atos." (Couto e Melo. 1998.f.8)

Em 1979 foi aprovado no Congresso o novo Código de Menores (a lei 6.697 de 10/10/79). No seu artigo $2^{\circ}$ define quem era considerado alvo dessa lei - os que estavam em situação irregular. Eram enquadrados nessa categoria os que estavam privados de condições essenciais de sobrevivência, saúde e instrução; vítimas de maus tratos ou castigos imoderados; em perigo moral; privados de representação ou assistência legal; com desvio de conduta, em virtude de grave inadequação familiar ou comunitária e os autores de infração penal. As crianças e adolescentes filhos de famílias pobres eram alvos das políticas discriminatórias da lei. Os juízes de menores poderiam decretar o afastamento das crianças de sua família de origem a qualquer momento.

Trassi (2006. p. 64 e seguintes) faz um levantamento da maneira como a sociedade via os adolescentes infratores na década de 1970. A perambulação pelas ruas e a mendicância eram associadas à delinquência. Apoiados na conduta médica, esses adolescentes eram tidos como anormais (oligofrênicos e doentes mentais).

Culpabilizava-se a ocorrência de adolescentes infratores pela conduta irresponsável dos pais, a chamada "desestruturação familiar". Na realidade, qualquer modelo familiar diferente do que era esperado como correto (pai, mãe e filhos convivendo na mesma casa) era considerado uma desestrutura familiar que poderia causar danos à personalidade dos filhos.

A falta de recursos econômicos da família também era considerada como causador de transtornos na conduta dos adolescentes. Ou seja, era considerado anormal aquele que era diferente. A diferença tinha viés científico 
como na Teoria da Carência Cultural, tão propagada na época e que povoa o imaginário social e o discurso de autoridades do setor até hoje.

No contexto da abertura política e instauração da democracia, mudanças foram sendo sentidas pelo conjunto da sociedade brasileira. A conquista dos direitos civis, ocorrência de transformações sociais e urbanas, transformações nas relações intersubjetivas, de trabalho e emprego, entre outras.

A década de 80 para o Brasil, do ponto de vista social e político foi extremamente importante. Houve mobilização de diversos setores da sociedade em favor da abertura política, ocorreu uma organização dos trabalhadores, foi elaborada uma nova constituição.

Em 1985 nasceu o Movimento Nacional de Meninos e Meninas de Rua que junto com outras Organizações Não Governamentais fundou o Fórum DCA - Fórum Nacional Permanente de Entidades Não Governamentais de Defesa dos Direitos da Criança e do Adolescente, responsável pela mobilização da sociedade civil para aprovar os artigos 227 e 228 da constituição e sua regulamentação: o Estatuto da Criança e do Adolescente (ECA - Lei 8069 de 13 de julho de 1990) ${ }^{28}$.

O antigo Código de Menores que se baseava na doutrina da situação irregular - a lei era para aqueles que não se enquadravam em características esperadas para aquele grupo da população - foi revogado. O ECA passou a considerar todas as crianças e adolescentes como sujeitos de direitos, é a doutrina da proteção integral.

O ECA é uma legislação considerada revolucionária e modelo internacional de estruturação da relação do Estado com as temáticas da infância e adolescência. Seu texto coloca crianças e adolescentes na condição de sujeitos de direito e introduz uma ampla reordenação da forma como a sociedade se relaciona com o Poder Público, além de transformar profundamente o entendimento que até então se tinha das políticas voltadas para esses segmentos populacionais. (ANDI. 2005. p.44)

\footnotetext{
${ }^{28}$ BRASIL. Estatuto da Criança e do Adolescente. Lei $N^{\circ}$ 8069. 13 de julho de 1990. Disponível em: $<$ http://www.planalto.gov.br/civil_03/Leis/L8069.htm. Acesso em: 21 nov 2006.
} 
Pereira (1998. Anexo) ${ }^{29}$ realizou uma comparação entre os códigos de menores e o Estatuto da Criança e do Adolescente em relação a quatro aspectos: concepção política e social, qual visão sobre criança e adolescente estava implícita, quais os mecanismos de participação social e quem deveria fiscalizar o cumprimento da lei.

A autora afirma que o código de 1927 visava proteção e vigilância da infância e adolescência vítimas de maus-tratos ou negligência familiar. $O$ então "menor" era visto como objeto de vigilância pelo juiz. Este podia ser auxiliado por um Conselho para promover a proteção dos "menores". A lei era discriminatória e parcial.

O código de 1979 também era um instrumento de controle sobre a infância e a adolescência. Porém essa lei incluía o Estado e a sociedade como omissos ou transgressores dos direitos básicos. Continuava a "menorização" da infância, principalmente dos pobres que eram vistos como em "situação irregular". A esses cabiam medidas judiciais. O juiz era responsável pelas medidas adotadas e devia zelar pela fiscalização e cumprimento da lei.

O Estatuto da Criança e do Adolescente de 1990, lei em vigência no país, é um instrumento de desenvolvimento social, voltado para todo o conjunto da população, garantindo proteção aos que se encontram em situação de risco social e pessoal. Crianças e adolescentes são considerados sujeitos de direitos e pessoas em condição peculiar de desenvolvimento. A sociedade civil e o Estado são responsáveis pela efetivação da lei. Criou-se uma instância de fiscalização na comunidade para acompanhar o desenvolvimento do trabalho do setor público.

O Estatuto foi fruto de um movimento da sociedade brasileira em favor das crianças e adolescentes do país e está de acordo com legislações internacionais como a Convenção das Nações Unidas sobre os Direitos das

\footnotetext{
${ }^{29}$ Anexo Disponível em: <www.fundabrinq.org.br/_Abrinq/documents/peac/diferenças.pdf.> Acesso em: 24 Janeiro 2008.
} 
Crianças; as Regras Mínimas das Nações Unidas para a administração da Justiça da Infância e da Juventude - Regras de Beijing; as Regras Mínimas das Nações Unidas para os Jovens Privados de Liberdade; as Diretrizes das Nações Unidas para a prevenção da Delinquiência Juvenil - Diretrizes de Riad.

Avanços podem ser percebidos entre os antigos códigos e o ECA, tanto no sentido da nova lei englobar todas as crianças e adolescentes, como ao considerá-los sujeitos em condição peculiar de desenvolvimento. A lei mais abrangente, não discriminatória, exige o comprometimento de toda a sociedade.

O ECA supera as atitudes assistencialistas e repressivas que tinham lugar no Brasil quando se falava em crianças e adolescentes "carentes", "abandonados", "delinquientes". A nova lei exige que o tratamento seja efetivado por força de lei, garantindo que todas as crianças e adolescentes ${ }^{30}$ tenham seus direitos assegurados. As crianças e adolescentes passam a ter direito a voz, a serem ouvidos por terem a total capacidade de se expressar. Eles não podem ficar a mercê de um poder autoritário que a tudo decide sem perceber as necessidades da criança.

O Estatuto da Criança e do Adolescente abrange temas que garantem a proteção e promovem o direito de crianças e adolescentes:

$\checkmark$ sobrevivência - vida, saúde, alimentação;

$\checkmark$ desenvolvimento pessoal e social - educação, cultura, lazer, profissionalização;

$\checkmark$ integridade física, psicológica e moral - respeito, dignidade, liberdade, convivência familiar e comunitária;

$\checkmark$ coloca crianças e adolescentes a salvo de todas as formas de situação de risco pessoal e social - negligência, discriminação, exploração, violência, crueldade, opressão ${ }^{31}$.

\footnotetext{
${ }^{30} \mathrm{O}$ ECA em seu artigo segundo afirma que criança são os indivíduos de 0 a 12 anos incompletos e que adolescentes são aqueles entre 12 e 18 nos incompletos.

${ }^{31}$ Idéias contidas no texto: Sayão, Y. Políticas Públicas de Atendimento para a Infância e Adolescência - Breve Histórico do Estatuto da Criança e do Adolescente. 13 março de 2002. (mimeo).
} 
Conhecer a história das leis que lidam com crianças e adolescentes no Brasil ajuda a entender como a sociedade pensa essa questão e embasado em quê algumas propostas políticas são defendidas por setores conservadores da sociedade

[...] A situação atual, que muitas vezes parece ganhar soluções milagrosas no discurso de políticos, especialistas e governantes, não é resultado de atos cometidos há pouco, senão de uma política que vem sendo construída historicamente e que possui raízes profundas na idéia da correção, da adequação, da repressão e do controle. (VIEIRA. 2003. p.40)

A redução da maioridade penal e outras alterações no ECA são propostas que ocorrem dede 1993, ou seja, quando o estatuto tinha apenas três anos. Soluções simplistas como a redução da idade penal para resolver o problema da criminalidade adolescente são atualizadas a cada evento de morte de pessoas onde há um adolescente envolvido. (Ver discussão no capítulo sobre a Mídia).

\subsection{O Estatuto da Criança e do Adolescente e a prática infracional}

O Estatuto dispõe sobre adolescentes que são acusados de cometerem atos infracionais. No Livro II, Título III - Da Prática de Ato Infracional, afirma o que considera como ato infracional e regula a idade penal:

Art. 103. Considera-se ato infracional a conduta descrita como crime ou contravenção penal.

Por esse artigo percebe-se que o estatuto se baseia no código penal descrito para a população acima dos 18 anos. Classifica, portanto, o ato adolescente como o faz com os adultos. Mas adverte que adolescente não pratica crimes e sim ato infracional.

Art. 104. São penalmente inimputáveis os menores de dezoito anos, sujeitos às medidas previstas nesta Lei.

Parágrafo único. Para os efeitos desta Lei, deve ser considerada a idade do adolescente à data do fato. 
Esse artigo apresenta um fato importante: apesar de não considerar crime o ato praticado por aqueles que possuem menos de 18 anos, considera que aquele que pratica uma infração deve ser responsabilizado.

Art. 105. Ao ato infracional praticado por criança corresponderão as medidas previstas no art. 101 (medidas de proteção).

Nos artigos 106 a 111, prevê os direitos individuais e as garantias processuais dos adolescentes acusados de autoria de ato infracional. Porém, como descreve Roman (2007.p. 46 e seguintes), as garantias processuais nem sempre são cumpridas.

Dos artigos 112 a 128 dispõe sobre as medidas socioeducativas. Essas são as medidas apresentadas pela lei para responsabilizar o adolescente sobre os seus atos. Elas se baseiam na educação e ressocialização.

Vale ressaltar alguns pontos.

As medidas socioeducativas são:

Art. 112 - advertência; obrigação de reparar o dano; prestação de serviços à comunidade; liberdade assistida; inserção em regime de semiliberdade; internação em estabelecimento educacional; qualquer uma das previstas no art. 101, I a VI (medidas de proteção).

$\S 1^{\circ}$ A medida aplicada ao adolescente levará em conta a sua capacidade de cumpri-la, as circunstâncias e a gravidade da infração.

$\S 2^{\circ}$ Em hipótese alguma e sob pretexto algum, será admitida a prestação de trabalho forçado.

Na prática, o que ocorre atualmente é que os adolescentes que cumprem uma medida socioeducativa de internação vivenciam o dia-a-dia do cárcere adulto.

Art. 114. A imposição das medidas previstas nos incisos II a VI do art. 112 pressupõe a existência de provas suficientes da autoria e da materialidade da infração, ressalvada a hipótese de remissão, nos termos do art. 127.

Estar acompanhado dos pais ou responsáveis no ato da audiência, freqüentar escola e possuir trabalho são atenuantes na decisão do juiz em relação a qual medida socioeducativa impor ao adolescente.

Da Internação: 
Art. 121. A internação constitui medida privativa da liberdade, sujeita aos princípios de brevidade, excepcionalidade e respeito à condição peculiar de pessoa em desenvolvimento.

Art. 122. A medida de internação só poderá ser aplicada quando:

I - tratar-se de ato infracional cometido mediante grave ameaça ou violência a pessoa;

II - por reiteração no cometimento de outras infrações graves;

III - por descumprimento reiterado e injustificável da medida anteriormente imposta.

$\S 1^{\circ}$ O prazo de internação na hipótese do inciso III deste artigo não poderá ser superior a três meses.

$\S 2^{\circ}$. Em nenhuma hipótese será aplicada a internação, havendo outra medida adequada.

Art. 123. A internação deverá ser cumprida em entidade exclusiva para adolescentes, em local distinto daquele destinado ao abrigo, obedecida rigorosa separação por critérios de idade, compleição física e gravidade da infração.

Parágrafo único. Durante o período de internação, inclusive provisória, serão obrigatórias atividades pedagógicas.

Pelo relato de Trassi (2006) verifica-se que o Estatuto vem sendo sistematicamente descumprido pelos órgãos responsáveis pelo cumprimento da medida socioeducativa de internação.

Art. 124. São direitos do adolescente privado de liberdade, entre outros, os seguintes:

I - entrevistar-se pessoalmente com o representante do Ministério Público;

II - peticionar diretamente a qualquer autoridade;

III - avistar-se reservadamente com seu defensor;

$I V$ - ser informado de sua situação processual, sempre que solicitada;

$V$ - ser tratado com respeito e dignidade;

VI - permanecer internado na mesma localidade ou naquela mais próxima ao domicílio de seus pais ou responsável;

VII - receber visitas, ao menos, semanalmente;

VIII - corresponder-se com seus familiares e amigos;

$I X$ - ter acesso aos objetos necessários à higiene e asseio pessoal;

$X$ - habitar alojamento em condições adequadas de higiene $e$ salubridade;

$X I$ - receber escolarização e profissionalização;

XII - realizar atividades culturais, esportivas e de lazer: 
XIII - ter acesso aos meios de comunicação social;

XIV - receber assistência religiosa, segundo a sua crença, e desde que assim o deseje;

XV - manter a posse de seus objetos pessoais e dispor de local seguro para guardá-los, recebendo comprovante daqueles porventura depositados em poder da entidade;

XVI - receber, quando de sua desinternação, os documentos pessoais indispensáveis à vida em sociedade.

$\S 1^{\circ}$ Em nenhum caso haverá incomunicabilidade.

$\S 2^{\circ}$ A autoridade judiciária poderá suspender temporariamente a visita, inclusive de pais ou responsável, se existirem motivos sérios e fundados de sua prejudicialidade aos interesses do adolescente.

Art. 125. É dever do Estado zelar pela integridade física e mental dos internos, cabendo-lhe adotar as medidas adequadas de contenção $e$ segurança.

Os relatos dos jovens entrevistados demonstraram que, nem sempre, receberam o tratamento adequado ao seu desenvolvimento e o que está previsto em lei.

Das Entidades de Atendimento

Art. 94. As entidades que desenvolvem programas de internação têm as seguintes obrigações, entre outras:

I - observar os direitos e garantias de que são titulares os adolescentes;

II - não restringir nenhum direito que não tenha sido objeto de restrição na decisão de internação;

III - oferecer atendimento personalizado, em pequenas unidades e grupos reduzidos;

$I V$ - preservar a identidade e oferecer ambiente de respeito e dignidade ao adolescente;

$V$ - diligenciar no sentido do restabelecimento e da preservação dos vínculos familiares;

VI - comunicar à autoridade judiciária, periodicamente, os casos em que se mostre inviável ou impossivel o reatamento dos vínculos familiares;

VII - oferecer instalações físicas em condições adequadas de habitabilidade, higiene, salubridade e segurança e os objetos necessários à higiene pessoal;

VIII - oferecer vestuário e alimentação suficientes e adequados à faixa etária dos adolescentes atendidos;

IX - oferecer cuidados médicos, psicológicos, odontológicos e farmacêuticos;

$X$ - propiciar escolarização e profissionalização;

XI - propiciar atividades culturais, esportivas e de lazer; 
XII - propiciar assistência religiosa àqueles que desejarem, de acordo com suas crenças;

XIII - proceder a estudo social e pessoal de cada caso;

$X I V$ - reavaliar periodicamente cada caso, com intervalo máximo de seis meses, dando ciência dos resultados à autoridade competente;

$X V$ - informar, periodicamente, o adolescente internado sobre sua situação processual;

$X V I$ - comunicar às autoridades competentes todos os casos de adolescentes portadores de moléstias infecto-contagiosas;

XVII - fornecer comprovante de depósito dos pertences dos adolescentes;

XVIII - manter programas destinados ao apoio e acompanhamento de egressos;

XIX - providenciar os documentos necessários ao exercício da cidadania àqueles que não os tiverem;

$X X$ - manter arquivo de anotações onde constem data e circunstâncias do atendimento, nome do adolescente, seus pais ou responsável, parentes, endereços, sexo, idade, acompanhamento da sua formação, relação de seus pertences e demais dados que possibilitem sua identificação $e$ a individualização do atendimento.

Pelo exposto verifica-se que o ECA determina como devem ser cada uma das medidas socioeducativas e em quais circunstâncias devem ser aplicadas. Todas as medidas devem contar com o propósito de promover o desenvolvimento do adolescente; garantir sua integridade física, moral e psicológica; responsabilizá-lo por seus atos; garantir que estejam regularmente matriculados em estabelecimento oficial de ensino e freqüentem as aulas; entre outras.

Apesar do Estatuto definir cada uma das medidas socioeducativas e as circunstâncias que devem ser aplicadas, ele não detalha como as instituições e os poderes legislativos e executivos de cada instância da federação devem executar suas determinações. Para isso foi criado pelo conjunto da sociedade (Estado e Sociedade Civil Organizada) - o SINASE - Sistema Nacional de Atendimento Socioeducativo - que proporciona diretrizes nacionais para o cumprimento do que é previsto no Estatuto da Criança e do Adolescente.

O SINASE é um Projeto de Lei que foi enviado ao Congresso Nacional e serve para regulamentar a execução das medidas destinadas ao adolescente, em razão do cometimento de ato infracional. 
Pelo texto do SINASE:

Entende-se por Sistema Nacional de Atendimento Socioeducativo o conjunto ordenado de princípios, regras e critérios, de caráter jurídico, político, pedagógico, financeiro e administrativo, que envolvem o processo de apuração de ato infracional e de execução de medida socioeducativa, incluindo-se, nele, o sistema nos níveis estaduais, distrital e municipais, bem como todos os planos, políticas e programas específicos de atenção ao adolescente infrator. ${ }^{32}$

O ECA necessita de delimitações como o SINASE propõe, mas também precisa desvincular as infrações com os artigos do código adulto e as medidas socioeducativas com as penas.

Importante lembrar que o ECA não está sendo totalmente aplicado. Nem em relação às condições fundamentais de existência - moradia, saúde, educação etc - nem em relação ao que se determina para a execução das medidas socioeducativas.

As unidades de internação deveriam ser unidades pequenas, com espaço físico adequado e propostas pedagógicas condizentes com o desenvolvimento do adolescente, com atendimento personalizado, oferecendo um ambiente de respeito e dignidade. Mas apesar disso existem ainda diversas unidades que não se adequaram ao necessário.

Hoje em dia eu não sei como que está [a Febem], que deve ter mudado algumas coisas, mas eu acho que está do mesmo jeito, do jeito que estava... a gente mal chegava, a gente já apanhava, entendeu? A gente já apanhava e como você vai se recuperar num lugar que você já chega apanhando... (Lucas)

\footnotetext{
32 Projeto de Lei sobre os sistemas de atendimento socioeducativo. (em tramitação no Congresso Nacional). Disponível em: <http://www.mj.gov.br/sedh/ct/spdca/atendimentosocioeducativo/ PROJETODELEIMEDIDASOCIOEDUCATIVAFINAL >. Acesso em: 21 nov 2006. No dia 12 de julho de 2007 chegou à Câmara Federal o projeto de lei que regulamenta o Sistema Nacional de Atendimento Socioeducativo (Sinase). O projeto foi entregue ao presidente da Câmara, deputado Arlindo Chinaglia (PT-SP).
} 
Lucas tem dúvidas de como está a Febem atualmente, mas infelizmente as notícias não são animadoras nem para São Paulo, nem para outros estados do país.

O Conselho Federal de Psicologia (CFP) e a Ordem dos Advogados do Brasil (OAB) realizaram a Inspeção Nacional às unidades de Internação dos Adolescentes em Conflito com a lei. Foram visitadas, simultaneamente no dia 15/03/2006, unidades de internação em 22 estados e distrito federal. "O objetivo era avaliar os níveis de efetivação dos direitos deferidos aos jovens nesta condição, denunciar as violações, suscitar o debate e propor ações".

As inspeções constataram que havia uma enorme gama de variações nos atendimentos oferecidos a esses jovens, mas em comum, encontraram irregularidades na efetivação das propostas socioeducativas, na adequação dos espaços físicos, no atendimento oferecido aos adolescentes como preconiza o ECA, entre outras irregularidades ${ }^{33}$.

Atualmente, cada estado ou município da Federação efetiva de maneira diversa as medidas socioeducativas. Por exemplo, o ECA e o SINASE determinam que as medidas socioeducativas de prestação de serviço à comunidade e de liberdade assistida devem ser coordenadas pelos municípios, porém, $60 \%$ das capitais ainda não contavam com a municipalização das medidas de meio aberto ${ }^{34}$.

Além das irregularidades presentes nas instituições responsáveis pelo oferecimento da medida socioeducativa de internação, existem outras distorções. Os juízes não seguem um padrão estabelecido nas suas orientações. Há razões subjetivas influenciando as determinações judiciais das medidas socioeducativas. As audiências lembram uma sessão de bronca, mostrando que os juízes consideram que esta deveria ter sido dada pelo pai e que, por falha na

\footnotetext{
${ }^{33}$ Um Retrato das Unidades de Internação dos Adolescentes em Conflito com a Lei - Ação conjunta CFP/OAB - Disponível em: <http://www.pol.org.br/publicacoes/pdf/relatoriocaravanas.pdf > Acesso em: 05 dez 2006

34 Conforme informações da Secretaria Especial de Direitos Humanos - Disponível em: $<$ http://www.mj.gov.br/sedh/ct/noticias-Anexo/apresentacaodolevantamentoconsolidado.doc $>$ Acesso em: 21 nov 2006.
} 
educação oferecida pela família do adolescente, quem estaria exercendo esse papel seria ele próprio.

Segundo o Instituto Latinoamericano das Nações Unidas para a Prevenção do Delito e Tratamento do Delinqüente (ILANUD): (ALMEIDA.; HOJDA; KAHN; SPOSATO. 2002) "Frequentemente os registros oficiais refletem os preconceitos do sistema de justiça criminal com relação a certos grupos, como negros, moradores de rua, moradores da periferia e do sexo masculino e até mesmo adolescentes em situação de risco".

Os juízes, ao exercerem sua função, longe de serem imparciais e neutros, fazem parte da história da nossa sociedade, reproduzindo em atos o que o imaginário social conforma.

[...] pois o que justifica a administração do sofrimento ao infrator é sua imagem socialmente construída como encarnação descontextualizada do mal, contra o qual a sociedade pode extravasar sua crueldade [...] (ROMAN. 2007. p.65)

A pesquisa [ADORNO; LIMA; BORDINI; 1999] mostrou que a aplicação do ECA pelo judiciário pode contribuir para a pouca credibilidade desta lei na medida que abranda as sanções para crimes graves. Considera-se que para a lei ganhar legitimidade na opinião pública, seu uso deveria ser absolutamente rigoroso sem o viés político-ideológico em sua aplicação, o que por um lado garantiria a igualdade de todos os cidadãos perante a lei e, por outro, a responsabilização de todos os adolescentes envolvidos com a prática do ato infracional, tal como preconiza o ECA. (TRASSI. 2006. p. 168)

Apesar do que determina a lei, o Juiz decide pessoalmente sobre a vida dos adolescentes. Não há defensor desde o início do processo, pelo menos os jovens entrevistados não relatam nada sobre isso.

Há uma lógica da moralização para fazer com que o adolescente sinta vergonha e arrependimento e seja punido pelo ato praticado, fato que pode ser interpretado pela constante utilização da medida de internação pelas Varas Especiais da Infância e Adolescência.

O sistema de justiça brasileiro e a população em geral acreditam que impingir punições a quem comete delitos tem a intenção de fazer sofrer aquele 
que transgrediu uma regra, além de amedrontar aquele que pensa em fazer o mesmo.

\subsection{As medidas socioeducativas em números}

As medidas socioeducativas são irregularmente distribuídas. Em janeiro de 2004 (ver tabela 3) havia no Brasil 39.578 adolescentes no sistema socioeducativo. Quase a metade deles cumpria a medida socioeducativa de liberdade assistida (47\%). A medida socioeducativa de semiliberdade era a menos aplicada (3\%), seguida da prestação de serviços à comunidade (19\%). Quase um quarto dos adolescentes estava privado de liberdade (24\%) e se juntarmos a internação provisória, esse percentual subia para $31 \%$.

O grande número de medidas de internação aplicadas aos adolescentes pode demonstrar como a sociedade, através de suas instâncias responsáveis por trabalhar com adolescentes que cometeram atos infracionais - a segurança pública e o judiciário - criminalizam em demasia os atos juvenis.

Tabela 3 - Número de adolescentes e jovens no Sistema Socioeducativo (SSE) segundo a modalidade de atendimento no sistema - Brasil ${ }^{1}$ (Janeiro/2004).

\begin{tabular}{|l|c|c|}
\hline $\begin{array}{l}\text { MODALIDADES DE } \\
\text { ATENDIMENTO }\end{array}$ & $\begin{array}{c}\mathbf{N}^{\circ} \text { DE ADOLESCENTES NO } \\
\text { SSE }\end{array}$ & \% DO TOTAL \\
\hline LIBERDADE ASSISTIDA* & 18.618 & $47 \%$ \\
\hline INTERNAÇÃO & 9.591 & $24 \%$ \\
\hline $\begin{array}{l}\text { PRESTAÇÃO DE SERVIÇOS } \\
\text { À COMUNIDADE** }\end{array}$ & 7.471 & $19 \%$ \\
\hline $\begin{array}{l}\text { INTERNAÇÃO } \\
\text { PROVISORIA*** }\end{array}$ & 2.807 & $7 \%$ \\
\hline SEMI-LIBERDADE**** & 1.091 & $3 \%$ \\
\hline BRASIL & 39.578 & $100 \%$ \\
\hline
\end{tabular}

Fonte: Levantamento da Subsecretaria de Promoção dos Direitos da Criança e do Adolescente/SEDH baseado em informações fornecidas pelos estados - Janeiro/2004.

1. Exceto Piauí para todos os tipos de MSE.

* Exceto Rio Grande do Sul, Espírito Santo, Minas Gerais e Sergipe.

** Exceto Acre, Roraima, Rio Grande do Sul, Distrito Federal, Espírito Santo, Minas Gerais e Rio de Janeiro.

*** Exceto Alagoas.

**** Exceto Mato Grosso, Tocantins e Espírito Santo. 
Há estados que aplicam mais medidas de internação do que outros, há municípios que não aplicam a medida socioeducativa de Prestação de Serviços à Comunidade. Esse fenômeno pode ser observado na tabela 4, abaixo: em 2004 a média nacional para adolescente cumprindo medida socioeducativa em meio fechado era de $34 \%$.

Comparada com a média nacional, a região centro-oeste era a que mantinha menos adolescentes privados de liberdade (28\%) e as regiões nordeste e sudeste eram as que mais privavam de liberdade os adolescentes em medidas socioeducativas, $37 \%$ e $36 \%$ respectivamente.

Tabela 4 - Número de adolescentes e jovens no Sistema Socioeducativo, por modalidade de medida, segundo região (Janeiro/2004).

\begin{tabular}{|c|c|c|}
\hline UF & MEIO FECHADO & MEIO ABERTO \\
\hline NORDESTE* (5.494) & $\mathbf{3 7 \%}(2.039)$ & 63\% (3.455) \\
\hline SUDESTE** (22.022) & $\mathbf{3 6 \%}(7.837)$ & $64 \%(14.185)$ \\
\hline SUL*** (6.413) & $\mathbf{3 1 \%}(1.971)$ & $69 \%(4.442)$ \\
\hline NORTE $^{* * * *}(2.048)$ & $31 \%(637)$ & 69\% (1411) \\
\hline CENTRO-OESTE ${ }^{* * * * *}(3.601)$ & $28 \%(1.005)$ & $72 \%(2.596)$ \\
\hline TOTAL BRASIL (39.578) & $34 \%(13.489)$ & $66 \%(26.089)$ \\
\hline
\end{tabular}

Fonte: Levantamento da Subsecretaria de Promoção dos Direitos da Criança e do Adolescente/SEDH baseado em informações fornecidas pelos estados - Janeiro/2004.

* Exceto Piauí para todas as medidas. Sergipe não informou sobre Liberdade Assistida (MEIO ABERTO) e Alagoas sobre Internação Provisória (MEIO FECHADO).

** Minas Gerais não informou sobre Liberdade Assistida (MEIO ABERTO) e Prestação de Serviços à Comunidade (MEIO ABERTO); Espírito Santo não informou sobre Liberdade Assistida (MEIO ABERTO), Prestação de Serviços à Comunidade (MEIO ABERTO) e Semi-Liberdade (MEIO FECHADO); Rio de Janeiro não informou sobre Prestação de Serviços à Comunidade (MEIO ABERTO).

*** Rio Grande do Sul não informou sobre Liberdade Assistida (MEIO ABERTO) e Prestação de Serviços à Comunidade (MEIO ABERTO).

**** Acre e Roraima não informaram sobre Prestação de Serviços à Comunidade (MEIO ABERTO); Tocantins não informou sobre Semi-Liberdade (MEIO FECHADO).

****** Distrito Federal não informou sobre Prestação de Serviços à Comunidade (MEIO ABERTO); Mato Grosso não informou sobre Semi-Liberdade (MEIO FECHADO).

Em 2006, o número total de internos no sistema socioeducativo de meio fechado, no Brasil, era de 15.426 adolescentes, sendo a maioria (10.446) na internação, seguidos da internação provisória (3.746) e da semiliberdade (1.234). 
Os cinco estados com maior população de internos eram São Paulo, Rio de Janeiro, Rio Grande do Sul, Pernambuco e Paraná, sendo que em São Paulo se concentravam 39\% dos adolescentes em cumprimento de regimes em meio fechado no Brasil, com um ligeiro decréscimo comparado a 2004 quando sua participação chegou a 46\%. Contudo, proporcionalmente à população jovem de cada estado, as unidades federativas que mais internavam eram Acre, Distrito Federal, Amapá, São Paulo e Rondônia.

O maior crescimento de lotação entre 2002 e 2006 aconteceu na internação provisória (34\%), enquanto o número de internos em semiliberdade cresceu apenas 9\%. Tal contraste sugere que na modalidade de atendimento estivesse prevalecendo o critério de uma suposta periculosidade dos adolescentes, levando a adoção da internação provisória como ação emergencial. Chama a atenção o fato de que em Santa Catarina, Paraná, Bahia e Acre existiam mais adolescentes em internação provisória do que em internação.

A medida de semiliberdade foi a menos aplicada de todas as modalidades, sendo inclusive inexistente nos estados do Espírito Santo, Mato Grosso e Tocantins. ${ }^{35}$

Devido às disparidades encontradas em cada estado da federação diversidade na aplicação das medidas socioeducativas, diferença nos gestores responsáveis por cada medida socioeducativa, aproximação ou afastamento às determinações do ECA e do SINASE, essa pesquisa restringiu as análises ao Estado de São Paulo e, sempre que possível, as estatísticas apresentadas levaram em consideração a capital.

Segundo dados levantados pela Secretaria Especial de Direitos Humanos $^{36}$, em janeiro de 2004, o estado de São Paulo tinha, 19.747 adolescentes no sistema socioeducativo. Esses números representavam metade

\footnotetext{
${ }^{35}$ Dados e análise retirados do site da Secretaria Especial de Direitos Humanos. Disponível em: $<$ http:// www.mj.gov.br/sedh/ct/noticias-Anexo/apresentacaodolevantamentoconsolidado >. Acesso em 21 nov 2006.

${ }^{36}$ Fonte: Levantamento da Subsecretaria da Promoção dos Direitos da Criança e do Adolescente/ SEDH baseado em informações fornecidas pelos estados. Disponível em: <http:// www.mj.gov.br/SEDH/ct/spdca/Adolescente-em-mse.doc> Acesso em 21 nov 2006.
} 
da população do sistema no Brasil como um todo e 0,4\% da população de 12 a 18 anos. Desse total, 32\% estavam em meio fechado (internação provisória, internação e semiliberdade) e $68 \%$ em meio aberto (Liberdade Assistida e Prestação de Serviços à Comunidade).

Em 2006 havia no estado de São Paulo 6.059 adolescentes em medidas restritivas de liberdade. (ver distribuição na tabela abaixo).

Tabela 5 - Número de Adolescentes em meio fechado - Estado de São Paulo em 2006.

\begin{tabular}{|l|c|c|c|c|}
\hline Ano & \multicolumn{4}{|c|}{ 2006 } \\
\hline $\begin{array}{l}\text { Internação } \\
\text { Provisória }\end{array}$ & 875 & 71 & 926 & $\begin{array}{c}\text { \% na Pop de 12 a 18 } \\
\text { anos }\end{array}$ \\
\hline Semiliberdade & 310 & 17 & 327 & \\
\hline Internação & 4627 & 179 & 4806 & 0,12 \\
\hline $\begin{array}{l}\text { Total Meio } \\
\text { Fechado }\end{array}$ & 5812 & 247 & 6059 & \\
\hline
\end{tabular}

Não há dados sobre as medidas de meio aberto para o estado. Sabe-se que no município de São Paulo, havia em 2006, 4.517 adolescentes cumprindo liberdade assistida e prestação de serviços à comunidade, com 3.741 e 776 adolescentes, respectivamente em cada medida ${ }^{37}$.

Apenas $0,2 \%$ dos adolescentes estavam envolvidos com atos infracionais. Existe uma falsa idéia de que os adolescentes são responsáveis pelo aumento da crueldade e da criminalidade. A essa idéia “... correspondem propostas de soluções que retiram dele sua característica de adolescente e o vêem exclusivamente como criminoso ou potencialmente criminoso." (TRASSI. 2006. p.15) E nesse sentido se instala o preconceito, o medo, a repugnância, o afastamento em prisões, cada vez mais cedo.

\footnotetext{
${ }^{37}$ As estatísticas disponíveis na Secretaria Especial de Direitos Humanos não são completas em cada ano de pesquisa, assim, alguns dados são encontrados só para um período e não para outro, ou só para regiões/estados e não municípios. O Ilanud em parceria com a SEDH está fazendo esse levantamento nacional sobre as medidas de meio aberto. Foi divulgado em maio de 2007 um relatório parcial, mas a coleta de dados ainda era incipiente, o que impossibilitou que os dados fossem considerados.
} 
Capítulo 10 - A MÍDIA 


\section{A MÍDIA}

As violências sensacionalistas que viram manchete na mídia ocultam as pequenas violências comuns feitas permanentemente com todos os moradores desses bairros [periferias], inclusive com os jovens delinquentes que são também vítimas, nada mais sendo a violência que eles praticam que uma resposta às violências mais invisíveis que eles sofrem desde sua primeira infância, na escola, no mercado de trabalho, [...] (BOURDIEU. 1999. p.79)

A mídia (jornais, revistas, rádio, televisão, internet etc) produz e reproduz uma determinada visão dos acontecimentos. Uma mídia responsável deveria apresentar ao público notícias contextualizadas, com visões plurais e divergentes sobre o assunto tratado, questionando os diversos atores responsáveis, indicando políticas públicas presentes ou que deveriam existir sobre a questão em foco.

Deveria entrevistar representantes dos governos, sociedade civil e especialistas para fundamentar um ponto de vista. Para isso também seria interessante a citação de pesquisas acadêmicas e a discussão sobre a importância da presença do papel das universidades. Discutir propostas de soluções para os problemas apresentados e a análise das legislações que organizam o assunto ajudaria o leitor a compor o seu ponto de vista sobre a questão em pauta.

A mídia tem um papel importantíssimo. Quando um assunto é tratado pela mídia ele ganha visibilidade.

Num cenário ideal, a mídia deve agregar ao espaço ocupado pelos acontecimentos cotidianos três abordagens - enxergar de maneira integrada um problema, buscar verificar se diferenças são (ou como podem ser) respeitadas, e localizar sempre a efetividade e a presença de ações públicas. A imprensa é um veículo notório de agendamento das prioridades de uma sociedade e de mobilização de suas instituições - e um meio indispensável de comunicação entre governo, organizações e sociedade. Oferecer uma visão focada nos elementos mínimos que, combinados, são necessários para que pessoas de um determinado grupo se desenvolvam, é contribuir definitivamente para o bem da coletividade. (ANDI. 2005. p.19) 
“[...] a mídia doravante faz parte integrante da realidade ou, se preferir, produz efeitos de realidade criando uma visão mediática da realidade que contribui para criar a realidade que pretende descrever." (BOURDIEU. 1999. p.75)

A juventude está em toda e nenhuma parte. Em toda porque é quase onipresente na mídia, seja como protagonista dourada do mundo do consumo, seja como protagonista condenável nas páginas policiais. E em nenhuma, pois o que se mostra da juventude são discursos e imagens estereotipadas a seu respeito, em vez das suas vozes, contradições, diferenças e reais necessidades. (ABRAMO; FREITAS; SPOSITO. 2000. capa)

A Agência de Notícias dos Direitos da Infância - ANDI ${ }^{38}$ - analisa diariamente o comportamento da imprensa escrita brasileira quando o foco são as crianças e os adolescentes. Esse monitoramente teve início em 1996 no Brasil e a partir de 2004 na América Latina.

O relatório intitulado "Infância na Mídia: a criança e o adolescente no olhar da imprensa brasileira" (ANDI. 2005. p.5) mostra a evolução da cobertura dos jornais brasileiros sobre infância e adolescência: em 1996 foram 10.700 inserções contra 161.706 no ano de 2004 em 45 jornais brasileiros.

O número bruto de notícias indica uma maior cobertura da imprensa escrita no Brasil, mas a qualidade precisa melhorar. Com raras exceções, as redações se pautaram pelo factual, perdendo valiosas oportunidades de discutir questões centrais para a qualidade de vida de crianças e adolescentes. Tal postura fica evidente com o decréscimo do número de textos que extrapolaram abordagens meramente descritivas. (ANDI. 2005. p.29)

O relatório da ANDI intitulado "Balas Perdidas: um olhar sobre o comportamento da imprensa brasileira quando a criança e o adolescente estão na pauta da violência" foi publicado em 2001. Esse relatório analisou a qualidade das notícias sobre violência envolvendo crianças e adolescentes como vítimas, agressores e/ou testemunhas em 46 jornais de 24 estados do Brasil.

\footnotetext{
${ }^{38}$ ANDI - www.andi.org.br
} 
A primeira constatação foi que $80 \%$ das matérias utilizaram o Boletim de Ocorrência como elemento principal, ou seja, o assunto foi tratado como "caso de polícia". Raramente foi cobrada a presença do poder público ou se denunciou a ausência de políticas públicas. $\mathrm{O}$ fato violento foi descontextualizado das circunstâncias que o engendrou. Houve uma clara falta de compromisso social e com a qualidade da informação gerada para o público.

O relatório (ANDI. 2001) destacou que a mídia fala de adolescentes e jovens em crimes violentos desproporcionalmente. A maioria das infrações cometidas por adolescentes é contra o patrimônio e não contra a pessoa, considerado pelo sistema de justiça como mais violento. Eles também são vistos mais como agressores do que como vítimas. Situação inversa do que ocorre na realidade como foi visto no capítulo "As violências".

O relatório destaca que a mídia:

[...] procura fazer um retrato do imaginário social que recobre o tema, imaginário que a mídia, ao mesmo tempo, reflete e molda. Reflete na medida em que os jornalistas fazem parte da sociedade que retratam e são portadores, como todos nós, de uma certa visão de mundo com relações aos fatos relatados. Molda na medida em que apresenta para o público aspectos específicos e parciais da violência que envolve adolescentes. (ANDI. 2001. p.22)

O mesmo relatório levantou três mitos que aparecem na imprensa e que auxiliam na propagação de inverdades. (ANDI. 2001. p. 15) Esses mitos aparecem porque as notícias são descontextualizadas das estatísticas sobre criminalidade em geral, não há uma discussão sobre políticas públicas pertinentes, os especialistas são pouco ouvidos, a legislação específica (ECA) quase nunca é citada e não é utilizada para sustentar discussões coerentes, entre outros aspectos.

$\checkmark$ Mito do Hiperdimensionamento: os adolescentes foram apontados pela imprensa brasileira como se grande número deles cometesse delitos;

$\checkmark$ Mito da Periculosidade: a imprensa brasileira enfatiza as ações dos adolescentes como sendo de extrema violência. No imaginário coletivo 
é como se os adolescentes fossem responsáveis por um número elevado de delitos graves. Há uma super-representação de crimes violentos e uma sub-representação de crimes não violentos;

$\checkmark$ Mito da impunidade: a impunidade é confundida com inimputabilidade. O desconhecimento sobre o ECA e as Medidas Socioeducativas auxiliam na compreensão distorcida sobre a realidade. As notícias fazem parecer que o adolescente que cumpre uma medida socioeducativa não está sendo responsabilizado por seu ato. A imprensa divulga o ponto de vista de que a "prisão" é a forma de "punir" o jovem e que dessa forma a família da vítima seria compensada.

O número de infrações adolescentes não chega a $10 \%$ dos delitos cometidos por adolescentes e adultos e o número de adolescentes que infracionam, em relação ao total de adolescentes brasileiros, gira em torno de $0,2 \%$. Ver capítulo "As violências" para maiores dados sobre a prática infracional de adolescentes.

A Coordenadoria de Análise e Planejamento da Secretaria de Segurança Pública de São Paulo mostra que os menores de 18 anos participaram de apenas $1 \%$ dos homicídios dolosos no estado (dados referentes ao período de janeiro a outubro de 2003). Segundo a mesma pesquisa, crianças e adolescentes estavam envolvidos em apenas 1,5\% dos roubos e 2,6\% dos latrocínios, o que descaracteriza as ações dos adolescentes como extremamente violentas. (ANDI. 2005. p.41)

A imprensa "[...] Faz muito barulho [...] só que atira para o alto. São balas perdidas, que não atingem o alvo da boa cobertura e por isso ferem o direito do leitor a uma informação de qualidade, pluralista e propositiva." (ANDI. 2001.p.16)

A mídia não cobra políticas públicas, não ajuda a pensar soluções, não contextualiza a violência em relação a economia, política, legislações etc., as 
fontes pesquisadas não são plurais e quando se fala em causas, os apontamentos são unilaterais.

Em 2002, o índice de matérias que apresentam crianças e adolescentes como agentes de violência representava $15,38 \%$ do total das notícias publicadas sobre o tema. Em 2003, passou para 18,20\%, mantendo-se em patamar semelhante - ligeiramente inferior - em 2004. A mídia deve estar atenta ao fato de que o número de adolescentes envolvidos em crimes é bastante inferior ao de meninos e meninas que são vítimas. (ANDI. 2005. p. 41)

As notícias sobre violência envolvendo crianças e adolescentes concentram o uso cotidiano de expressões pejorativas. O termo "menor" é o mais utilizado. Em 2003, a temática já concentrava parte significativa das matérias com menções depreciativas - 32,13\% delas a tinham como foco principal. Mas, em 2004, a Violência passa a concentrar 56,95\% das notícias com termos pejorativos. (ANDI. 2005. p.31)

Os relatórios apresentados pela $\mathrm{ANDI}^{39}$ e publicados em 2001, 2005 e 2007 mostraram que a grande maioria das inserções $(80 \%)$ era de reportagens descritivas.

Elas não apresentam a informação de forma plural e divergente, contextualizada, portando denúncias e soluções para os problemas, apresentando políticas públicas pertinentes ou legislações que tratam sobre criança e adolescente.

As fontes ouvidas para a elaboração dos textos foram unilaterais, sem a presença de estudos e pesquisas que embasassem as informações contidas. As crianças e adolescentes envolvidos ou suas famílias foram ouvidos em poucos casos.

\footnotetext{
39 ANDI. Balas Perdidas: um olhar sobre o comportamento da imprensa brasileira quando a criança e o adolescente estão na pauta da violência. ANDI/DCA-MJ/ AMENCAR. Novembro 2001. Disponível em: $<$ http://www.andi.org.br>. Acesso em: 23 maio 2007.

ANDI. Relatório Infância na Mídia: a criança e o adolescente no olhar da imprensa brasileira. ANDI. Apoio UNICEF/ Inst, Telemig Celular/ Inst. Ayrton Senna . Ano 10. Número 14. Julho 2005. Disponível em: $<$ http://www.andi.org.br>. Acesso em: 23 maio 2007.

ANDI. Direitos, Infância e Agenda Pública: uma análise comparativa da cobertura jornalística latinoamericana. ANDI/ Rede ANDI América Latina. Brasília: ANDI 2007. 74p. il. color. Disponível em: $<$ http://www.andi.org.br>. Acesso em: 15 set 2007.
} 
A mídia trata a violência como sinônimo de criminalidade. Violência é também falta de condições dignas de existência, desrespeito às diferenças, falta de educação e saúde de qualidade etc.

Apenas 4,8\% das notícias enfocam o poder público na problemática infância/adolescência e violência. A imprensa não cobra os atores responsáveis pela elaboração e implementação de políticas públicas para o setor, assim como não ajuda na busca por soluções. A constatação do quanto não se debatem ou sequer se mencionam Políticas Públicas Governamentais voltadas para o enfrentamento dos inúmeros casos de violação de direitos é entristecedor. Em 2003, o número de matérias que enfocavam tais políticas representava apenas $0,51 \%$ do total das notícias sobre o tema da Violência. Em 2004, essa participação diminuiu ainda mais, para 0,45\%. (ANDI. 2005. p. 41)

O Estatuto da Criança e do Adolescente foi citado em pouquíssimas vezes. Dados estatísticos sobre a criminalidade em geral poderiam auxiliar na contextualização da violência sofrida ou praticada por crianças e adolescentes, mas também foram citados poucas vezes nas matérias envolvendo esse público.

A ótica da "ineficiência policial" e da "falta de segurança" prevaleceu nas notícias. Passou-se a idéia de que a violência sofrida ou praticada por adolescentes era um "caso de polícia" e que se houvesse mais policiamento haveria menos violência. Essa visão é parcial e unilateral.

As próprias crianças e os adolescentes, além de suas famílias foram responsabilizados excessivamente pela mídia para justificar a violência. A falta de políticas públicas para que crianças e adolescentes possam crescer com dignidade quase nunca é discutida pela mídia brasileira.

Quando a imprensa discutiu alguma política pública ao relatar casos de violência envolvendo crianças e adolescentes (isso ocorreu em apenas 4,8\% das inserções) as políticas mencionadas foram em relação à política de segurança, reforço no efetivo policial ou alteração na legislação vigente, ou 
seja, as reportagens mostraram uma visão policialesca do assunto. (ANDI. 2001. p. 25)

A violência não foi tratada como fato social e de responsabilidade das três esferas de governo e da sociedade civil. A violência foi tratada individualmente.

Cindindo completamente a ligação entre criminalidade e o funcionamento da sociedade, a mídia desconsiderou as condições sociais que ajudam a explicar a criminalidade: a desigualdade social, o desemprego, as políticas insuficientes de atenção à juventude, a valorização do indivíduo que possui bens, o desrespeito aos direitos fundamentais do cidadão etc.

A mídia produz e reproduz o que acontece no campo ideológico. Uma dissociação entre o adolescente e as condições que o movimentam para a prática infracional ficou premente, como se a imagem do adolescente estivesse colada na de infrator. Manobras ideológicas transformam o adolescente em um ser perigoso que deve ser temido. Ele é mostrado, abstraído das redes sociais que o constituem, transformando-o em um monstro sem rosto, mas sempre pobre, morador de favelas, portando uma arma, ameaçando pessoas.

"Desgarrados das relações sociais que os definem, jovens aparecem colados à infração, como se esta lhes fosse algo intrínseco. A expressão adolescente infrator é forjada de modo que o sujeito e predicado se fundem, fazendo o atributo infrator ser parte da natureza do ser." (ROMAN. 2007. p. $54)^{40}$ Além disso, reforça uma visão estereotipada de que os crimes mais violentos são cometidos por adolescentes.

A mídia reproduz a visão de um olhar vigilante, um olhar de dominação sobre o dominado. Olhar esse também disseminado pela polícia.

As imagens em tempo real do jovem protagonista do seqüestro do ônibus 174 na cidade do Rio de Janeiro mostraram como a mídia pode construir um monstro em poucos segundos. Morador de rua, sobrevivente da

\footnotetext{
${ }^{40}$ Roman, 2007. p.51 a 54 analisa reportagens do Fantástico sobre adolescentes que cometeram atos infracionais, mostrando como a grande imprensa televisiva manipula e desconstrói a informação.
} 
chacina da candelária, informações transformadas em horror pela grande imprensa. Não o horror de como o ser humano é tratado pelas políticas públicas brasileiras, ou melhor, pela ausência delas, mas o horror da aparição de um sujeito cuja história foi usada para justificar um único ato.

Em relação às rebeliões de adolescentes internados em instituições para o cumprimento da medida socioeducativa de internação, a mídia espetaculariza as ações, estigmatiza o jovem perante a sociedade, transformando-os em adolescentes violentos. A linguagem midiática fascina, as imagens impressionam. A aparição perversa do adolescente pobre é mostrada como cenas de um filme de ficção.

No artigo intitulado: "Análise do discurso da imprensa sobre rebeliões de jovens infratores em regime de privação de liberdade", as autoras NJAINE e MINAYO (2002) relataram uma pesquisa em que analisaram como a imprensa escrita do Rio de Janeiro - através dos jornais O Globo, O Dia e Jornal do Brasil - propôs matérias sobre as rebeliões de adolescentes que cumpriram medida socioeducativa de internação nas unidades destinadas a esse fim, no período de setembro de 1997 a agosto de 1998.

A pesquisa analisou os seguintes aspectos: contextualização das instituições para internação do adolescente que cumpria medida socioeducativa de privação de liberdade; as diferentes representações dos atores envolvidos nas rebeliões e quais os motivos, atribuídos pelos jornais, para acontecerem as rebeliões e suas consequiências.

Com algumas diferenças entre os três jornais, foi possível perceber que no geral foram justificadas as ações violentas e repressivas contra os adolescentes por estes serem considerados extremamente perigosos e agressivos, com uma "natureza essencialmente ruim". As causas das rebeliões raramente foram discutidas com profundidade e suas conseqüências foram analisadas apenas em relação a danos materiais e não foram mencionados os efeitos da repressão sofrida pelos adolescentes. 
Os locais de internação foram descritos como locais para bandidos e cadeias e não unidades de medidas socioeducativas para adolescentes em conflito com a lei.

Em relação aos atores envolvidos, raramente os adolescentes ou suas famílias foram ouvidos, sendo dada ênfase para os representantes da lei na área da infância e juventude, além dos funcionários das unidades de atendimento. Em segundo lugar foram ouvidos representantes das entidades civis que lutam na defesa dos direitos das crianças e adolescentes e em terceiro os representantes da segurança pública.

"Prevalecem, portanto, nessa "arena" discursiva, a voz do Estado, das fontes públicas de informação que tendem a ser impessoais, legalistas e reafirmadoras do status quo. Concluindo, na quase totalidade dos textos faltou a palavra dos sujeitos principais, restando-lhes, apenas, a linguagem dos gestos de revolta." (NJAINE e MINAYO. 2002. p. 295)

Njane e Minayo (2002) também afirmaram que a mídia fortalece uma visão negativa e preconceituosa com relação aos adolescentes autores de atos infracionais, contribuindo com a aprovação, por parte da população, de ações violentas contra esse grupo. A imprensa, muito excepcionalmente contribui para uma reflexão mais crítica sobre a complexidade do contexto em que vivem e atuam os adolescentes que cometem atos infracionais.

"A ideologia que os discrimina e os desconhece como sujeitos de direitos e os substantiva como "menores" se produz na sociedade e se reproduz na imprensa por meio do estigma de marginalidade." (NJAINE e MINAYO. 2002. p. 296)

A importância da pesquisa se baseou na idéia de que "[...] nas sociedades modernas, esses meios [de comunicação] ocupam um lugar privilegiado de produção e reprodução do real, tornando-se poderosos interferentes na organização do espaço relacional". (Hobsbawn, 1995; Ramonet, 1998 citado por NJAINE e MINAYO. 2002. p. 286) 
Cada meio de comunicação destina-se a um determinado público e possui uma linha editorial, ou seja, cada meio de comunicação está a serviço de alguém e tem interesses específicos em divulgar uma notícia que irá informar os leitores, mas também ajudá-los a compor uma opinião sobre aquele assunto. Assim, a mídia pode criticar, transformar ou ajudar a manter uma dada situação.

Partindo da informação ${ }^{41}$ de que a maioria dos meios de comunicação do país (emissoras de TV, Rádios e jornais impressos) pertence a poucas famílias abastadas, é possível imaginar que as informações veiculadas têm o intuito de afirmação do poder dos ricos sobre os pobres. "[...] A mídia latinoamericana enfrenta um forte processo de concentração e uso político de seus conteúdos.” (ANDI. 2007. p.10)

[...] Os meios de comunicação agem como construtores privilegiados de representações sociais sobre o crime e a violência, não apenas nomeando e classificando esta prática social, mas criando um circuito de produção de sentidos, passando mesmo a organizá-los, na medida em que pauta a violência na agenda diária da constituição de discursos e sujeitos sociais, aciona práticas institucionais e políticas, convocando sujeitos em direção a alguma coisa. (VICENTIN. 2005. p. 263)

E as autoras Njaine e Minayo afirmam “[...] a mídia não cria preconceitos, julgamentos ou verdades, mas absorve o imaginário social, revestindo-o de uma roupagem especial, tecnicamente sofisticada e específica para agradar aos mais diferentes segmentos sociais a aos mais variados gostos". (2002. p.286).

E eu acrescentaria, se a mídia não cria preconceitos ou verdades, pelo menos em relação a adolescentes que cometem ato infracional ela tem sido bastante incisiva em valorizar preconceito e descrédito frente a essa população, ajudando a manter uma visão distorcida do Estatuto da Criança e do Adolescente (ECA).

A população em geral, e mesmo alguns profissionais que trabalham com esse público desconhecem esse importante instrumento legal de garantia

\footnotetext{
${ }^{41}$ Informações contidas no Documentário "Muito Além do Cidadão Kane" de Simon Hartog. 1993.
} 
de direitos das crianças e adolescentes. Como foi demonstrado pelos relatórios da ANDI, o Estatuto foi citado poucas vezes quando se fala de crianças e adolescentes: "[...] é possível concluir que a imprensa tem contribuído de forma limitada para divulgar o conteúdo do ECA e o que ele representa para a sociedade." (ANDI. 2005. p.6)

Em $80 \%$ da amostra, o Estatuto aparece de forma pouco significativa. $\mathrm{Na}$ maioria das notícias em que o Estatuto da Criança e do Adolescente foi mencionado, a imprensa estava cobrindo questões relacionadas a Direitos \& Justiça (27,5\%), Medidas Sócioeducativas (13,9\%) e Violência (em geral ou de cunho sexual, com 19,1\% dos textos). Entretanto, é uma visão muito limitada associar o ECA, fundamentalmente, a esses assuntos. (ANDI. 2005. p. 46)

A imprensa brasileira mostrou que há muito que avançar no debate e conhecimento da população sobre o Estatuto da Criança e do Adolescente. A lei foi apresentada genericamente em $36,9 \%$ dos textos. Veja tabela abaixo retirada de ANDI (2005. p.45) em que aparecem as formas como a lei foi citada no noticiário da imprensa escrita.

\section{Tabela 6 - Como o Estatuto da Criança e do Adolescente foi citado nas matérias em que foi mencionado}

\begin{tabular}{|l|l|}
\hline COMO O ECA APARECEU NOS TEXTOS & \\
\hline Foi mencionado genericamente & $36,9 \%$ \\
\hline Foi apresentado como tendo sido descumprido & $16,0 \%$ \\
\hline Um artigo específico foi mencionado & $14,9 \%$ \\
\hline Foi apresentado como não totalmente implementado & $5,4 \%$ \\
\hline Foi apresentada uma explicação de como o ECA é aplicado & $5,1 \%$ \\
\hline $\begin{array}{l}\text { Foi apresentado como uma das soluções para um problema relacionado à } \\
\text { infância e adolescência }\end{array}$ & $3,9 \%$ \\
\hline $\begin{array}{l}\text { Foi apresentada/discutida/analisada a necessidade específica de sua } \\
\text { modificação com relação à maioridade penal (redução) }\end{array}$ & $2,6 \%$ \\
\hline Foi elogiado genericamente & $2,5 \%$ \\
\hline Foi apresentado como uma inovação legislativa & $2,5 \%$ \\
\hline Foi apresentada uma defesa à manutenção do texto da lei & $2,4 \%$ \\
\hline $\begin{array}{l}\text { Foi apresentada uma necessidade específica de alteração que visa o } \\
\text { melhoramento da legislação à luz dos direitos da infância e adolescência }\end{array}$ & $2,4 \%$ \\
\hline $\begin{array}{l}\text { Foi apresentada a necessidade específica de sua modificação com relação à } \\
\text { introdução de penas mais duras(exceto a redução da maioridade) }\end{array}$ & $1,7 \%$ \\
\hline
\end{tabular}




\begin{tabular}{|l|c|}
\hline Foi apresentado como responsável pelo aumento da criminalidade & $1,5 \%$ \\
\hline Foi apresentada a necessidade genérica de sua modificação & $1,0 \%$ \\
\hline Foi apresentada ou discutida uma alteração já efetivada & $0,8 \%$ \\
\hline Foi comparado a outras leis de outros países ou internacionais & $0,6 \%$ \\
\hline
\end{tabular}

Porém o relatório da ANDI de 2005 (p.44) observou avanços em relação ao que a mídia brasileira apresentou sobre o Estatuto :

$\checkmark$ foi pequena a cobertura contrária às determinações do ECA: apenas $5,8 \%$ dos textos advogaram pela redução da maioridade penal, sugeriram sanções mais duras para os adolescentes ou atribuíram ao Estatuto o aumento da criminalidade;

$\checkmark$ as matérias que teceram elogios ao documento ou o defenderam explicitamente somaram $14,3 \%$ do material analisado - ele foi identificado como uma solução para os problemas das novas gerações e uma importante inovação de cunho jurídico, sendo comparado favoravelmente a outras legislações internacionais. A imprensa também defendeu a manutenção do texto atual e, quando propôs eventuais modificações, fez à luz dos direitos da infância e da adolescência

$\checkmark$ a imprensa teve clara percepção de que algumas determinações do ECA não são respeitadas pelas autoridades. Em 26,5\% da amostra, houve referências de que o Estatuto está sendo descumprido ou não está totalmente implementado. Esse enfoque representou um importante avanço por parte da mídia, resultando em um trabalho jornalístico mais crítico e aprofundado, que extrapolou a mera menção à lei em vigor.

A parcial aplicação dos preceitos do ECA produz um descrédito aos seus conceitos e no trabalho socioeducativo com adolescentes autores de atos infracionais. O Estatuto é criticado por uma parcela da população e até por alguns representantes da lei, mas como destruir um instrumento que, apesar dos seus quase 18 anos de existência, ainda não foi totalmente implementado?

As matérias jornalísticas ainda não respeitam a nomenclatura proposta pelo Estatuto. Crianças e adolescentes são tratados por "menores"; os juízes da infância e juventude são tratados pela antiga denominação de "juizado de menores". "Somente quando os filhos das classes média e alta viram notícia, o termo adolescente costuma ser utilizado". (ANDI. 2001. p.22) 
Os agentes responsáveis pela proteção integral de crianças e adolescentes foram ignorados pelas reportagens. Os conselhos tutelares e de direitos foram ouvidos em apenas 2,5\% das matérias que falavam sobre violência. $\mathrm{O}$ conceito de garantia de direitos proposto pela legislação continuou desconhecido pela grande maioria da população, pois as notícias divulgadas carregavam uma grande carga de preconceito e desconhecimento sobre o assunto.

“[...] A imprensa preocupa-se muito pouco em confrontar o que define a legislação com a realidade e em cobrar a responsabilidade pela ausência dessas políticas públicas.” (ANDI. 2001. p.12)

A mídia enfatizou pouco o papel do judiciário, do ministério público e da defensoria pública para tratar dos direitos dos cidadãos.

Em relação às fontes consultadas para elaboração das matérias, houve uma clara predileção por entrevistar representantes do poder público. O Executivo, Legislativo, Judiciário, Ministério Público e Polícia foram responsáveis por 40,52\% das fontes consultadas em 2004 (ANDI. 2005. p. 48)

Em 2003 houve uma tendência de concentração das fontes no Executivo Federal e redução de consultas à Polícia. Houve também um acréscimo sensível na presença do Poder Legislativo - Câmara dos Deputados e Senado Federal, Assembléias Legislativas e Câmaras Municipais.

As fontes da Sociedade Civil destacaram-se como as mais presentes no noticiário em 2003 com 44,8\% das citações, praticamente o mesmo índice de 2002. Mas em 2004 esses atores perderam espaço para os Poderes Públicos, principalmente da instância Federal.

Também diminuiu em 2004 a presença na mídia dos Cidadãos Comuns, da Família, da Criança e do Adolescente, das Organizações da Sociedade Civil, dos Conselhos Tutelares e dos Conselhos de Direitos. (ANDI. 2005. p.50).

Essa modificação nas fontes consultadas, com a diminuição da voz da polícia e aumento das vozes do setor público pode ser considerada um avanço. 
Porém, a ausência de cidadãos comuns, das famílias e dos jovens envolvidos, dos conselhos de direitos e tutelares demonstra que não houve uma preocupação de certa parcela dos jornalistas brasileiros em embasar suas afirmações a partir da discussão de fontes diversificadas de informação.

Ao consultar um conjunto limitado de fontes, os profissionais da mídia colocam em risco a qualidade e mesmo a credibilidade da informação. A pequena diversidade de pontos de vista afeta o debate público democrático e reduz o horizonte temático. $\mathrm{O}$ compromisso com a imparcialidade cai sob suspeita e quem perde é o leitor, prejudicado no entendimento dos fatos centrais da realidade cotidiana. (ANDI. 2005. p.48)

No caso da imprensa, houve duas tendências mais evidentes em relação à infração juvenil, tal qual tratada pelo ECA. Uma afirma a incapacidade do Estatuto para resolver o problema da criminalidade. A segunda busca ressaltar a complexa realidade da infância e da juventude brasileiras, sobretudo os problemas dos segmentos empobrecidos e miseráveis. A primeira tem muito mais força e apelo.

A imprensa tem o papel de divulgar informações, mas também tem o poder de manipulá-las. Tem o poder de escolher os assuntos e os agentes que o debaterão. Poderia dar voz a vários setores da sociedade, mas geralmente privilegia um dos lados de uma determinada questão.

[...] É importante assinalar também que a cobertura jornalística da violência contra crianças e adolescentes está muito mais centrada na delinquência que na vitimação. (NJAINE e MINAYO. 2002. p. 288)

“[...] como espaço de mediação do debate público, a imprensa acaba por refletir também as posições mais conservadoras da sociedade, que atuam como forças de resistência à consolidação de diretrizes mais avançadas de garantia de direitos das novas gerações”. (ANDI. 2007. p. 11)

Toda vez que um adolescente aparece envolvido em crimes violentos contra pessoas economicamente favorecidas, o conhecimento parcial ou distorcido do ECA leva certos setores da população a promover uma campanha de redução da idade penal de 18 para 16 anos, ou até 14 anos. 
Exemplo dos casos que ficaram conhecidos como o assassinato do casal de adolescentes Liana Friedenbach e Felipe Caffé pelo adolescente "Xampinha" em 2003 e do assassinato de "João Vitor", uma criança com então 7 anos em 2007, no qual houve a participação de um adolescente.

\begin{abstract}
Grande parte destes textos trazia opiniões praticamente unilaterais, dando espaço privilegiado aos defensores da redução da maioridade penal. [...] Nomes como Dom Aloísio Lorscheider, o rabino Henry Sobel, o procurador de Justiça Paulo Afonso de Paula, o então presidente do Supremo Tribunal Federal, Maurício Corrêa, e a apresentadora Hebe Camargo pediram punições mais severas aos adolescentes em conflito com a lei. Seu argumento era de que, assim, o número de crimes cometidos por jovens com menos de 18 anos cairia. (ANDI. 2005. p.41)
\end{abstract}

Há um projeto de lei tramitando na Comissão de Constituição e Justiça da Câmara dos Deputados para a redução da idade penal. O projeto defende que os jovens são os principais responsáveis pelo aumento da criminalidade no Brasil e que o Estatuto da Criança e do Adolescente não pune o jovem com o rigor necessário, devendo este ser enquadrado dentro dos parâmetros da legislação adulta.

Analisando essas considerações presentes nas falas das autoridades que lidam com o assunto e nas discussões do congresso nacional (responsável por alterações nas leis) algumas ponderações são importantes:

Desde há muito tempo atrás a prática de transferir adolescentes infratores para penitenciárias já vem ocorrendo no estado de São Paulo ${ }^{42}$. Vicentin (2005. Cronologia) aponta alguns episódios a partir de 1999. Portanto, essa prática não intimida que os jovens cometam novas infrações por medo do encarceramento. Mas, por outro lado, afasta o problema do convívio social pelo confinamento.

Segundo dados do DEPEN - Departamento Penitenciário Nacional, em junho de 2007, 34\% dos presos no Brasil tinham idades entre 18 e 24 anos e

\footnotetext{
${ }^{42}$ Maria de Lurdes Trassi proferiu palestra no I ULAPSI que ocorreu em São Paulo no ano de 2005. $\mathrm{Na}$ ocasião fez um relato preciso das diversas vezes em que os adolescentes foram transferidos da Febem para penitenciárias.
} 
$27 \%$ tinham idades entre 25 e 29 anos. Se as duas faixas etárias forem somadas, tem-se um total de $62 \%$. Ou seja, a grande maioria dos presos era composta por pessoas com menos de 30 anos. Com esses dados é possível afirmar que o medo da consequiência da prisão não é empecilho para nenhum jovem cometa crimes.

Veja a tabela abaixo ${ }^{43}$.

Tabela 7 - Quantidade de preso por faixa etária no sistema penitenciário adulto no estado de São Paulo em junho de 2007

\begin{tabular}{|c|c|c|c|}
\hline Idade (anos) & $\begin{array}{l}\text { Sexo } \\
\text { masculino }\end{array}$ & $\%$ & \\
\hline 18 a 24 & 39882 & 34,75 & \multirow{2}{*}{$\begin{array}{l}62,03 \% \text { tem idades } \\
\text { entre } 18 \text { e } 29 \text { anos }\end{array}$} \\
\hline 25 a 29 & 31368 & 27,33 & \\
\hline 30 a 34 & 20471 & 17,84 & \\
\hline 35 a 45 & 15624 & 13,62 & \\
\hline 46 a 60 & 6042 & 5,26 & \\
\hline Acima de 60 & 1185 & 1,03 & \\
\hline $\begin{array}{l}\text { Não } \\
\text { informado }\end{array}$ & 193 & 0,17 & \\
\hline Total & 114765 & & \\
\hline
\end{tabular}

Encarcerar cada vez mais cedo não é a solução!

Esse argumento reforça que, mesmo sabendo das conseqüências, os adultos jovens continuam praticando crimes, o que invalida a análise de que por medo da cadeia e das duras consequiências os adolescentes não cometeriam infrações. Ademais, pela fala dos jovens entrevistados foi possível perceber que muitas unidades da Febem funcionam como cadeias na prática, apesar de terem o nome de unidades socioeducativas.

43 Dados do Ministério da Justiça. Departamento Penitenciário Nacional. Sistema integrado de informações penitenciárias. INFOPEN. Disponível em: <www.mj.gov.br/depen> Acesso em: 19 novembro 2007. 
Ao propor que a maioridade penal passe dos atuais 18 anos para $16 \mathrm{ou}$ até 14 anos, essas propostas tendem a reduzir o fenômeno da prática infracional de adolescentes a condições individuais. Tentam mostrar também que a lei seria muito branda com pessoas que já têm condições de discernir o que estão fazendo. Outra interpretação possível é imaginar que prendendo os adolescentes em cadeias, a criminalidade diminuiria.

As argumentações são falsas, pois como já foi demonstrado em outro capítulo, o aumento da criminalidade entre os jovens segue o aumento da criminalidade em geral. Apenas uma pequena parcela dos adolescentes brasileiros se envolve com a criminalidade e quando isso ocorre, na grande maioria das vezes, os crimes cometidos não são violentos.

O Estatuto responsabiliza o adolescente, sua família, a sociedade civil e o Estado pelo ato cometido, pois afirma a necessidade de políticas sociais que promovam o desenvolvimento das famílias, das crianças e adolescentes. Sua proposta inovadora não vem sendo respeitada pelos atores sociais responsáveis em fazê-lo.

Endurecer as consequiências pelo cometimento de um crime não faz com que se reduza a participação das pessoas em atos violentos. "[...] Aumentar penas é, antes de mais nada, uma estratégia simplista constantemente utilizada por aqueles que não têm interesse de atuar sobre as verdadeiras causas da violência, ou disposição para romper interesses corporativos e propor a reforma sistemática do aparato de aplicação do direito no Brasil [...]" (ANDI. 2001. p. 29)

O mesmo relatório da ANDI (2001. p. 29) afirma que o endurecimento das penas para crimes hediondos não diminuiu os crimes especificados pela nova lei. Além disso, os países que possuem pena de morte continuam produzindo pessoas que cometem crimes. Temer consequiências mais duras não impede que um indivíduo pratique delitos.

Adorno, Bordini e Lima (1999) apontam que a estratégia de repressão à delinqüência juvenil, com encarceramento e penas mais severas foi utilizada 
por países como Inglaterra e EUA na década de 90. Apesar das taxas de envolvimento dos adolescentes com crimes violentos terem diminuído, não houve consenso para suas causas. Além da repressão, outras razões foram levantadas: mudanças demográficas e no comportamento da criminalidade em geral, supervisão comunitárias e sistemas de mediação, também presentes na legislação.

Sales (2004. p.16) apoiada em pesquisas anteriores afirma que as políticas punitivas das últimas décadas no Brasil não produziram o efeito de limitar comportamentos criminosos e violentos.

Reduzir a maioridade penal fará com que os adolescentes e jovens sejam encarcerados cada vez mais cedo, incrementando as já assustadoras estatísticas de criminalidade adulta. Grande parte da população encarcerada no sistema prisional é jovem (61,50\% tem idade entre 18 e 29 anos conforme já foi apontado anteriormente) e a reincidência da prática de crimes na população adulta gira em torno de $45 \%$ (ANDI. 2001. p. 29).

Esses dados demonstram que há muito que se questionar e discutir no sistema prisional adulto. Encarcerar jovens é passar o problema para adiante sem solucioná-lo.

A ANDI verificou que o comportamento da imprensa em relação às questões relativas a mudança da legislação quando o assunto é a redução da maioridade penal é cíclico, quase sempre relacionada a crimes com forte apelo emocional e ouvindo poucas opiniões divergentes. Quando os vitimados são filhos das classes abastadas a imprensa traz um forte apelo para a mudança na legislação.

"As soluções apresentadas durante as crises tendem a ser imediatistas e desprovidas de reflexão sobre os acontecimentos.” (ANDI. 2001. p. 27)

Sem questionar as políticas sociais e a necessidade de garantia de direitos, as matérias que falam sobre violências acabam apontando soluções repressoras, penais, legais e que individualizam o problema: $14 \%$ das matérias apresentaram como solução para o problema da violência mudança na 
estrutura familiar; 10,5\% apontaram a falta de campanhas pela paz; 9,3\% apontaram a necessidade de aumento no efetivo policial; 9,3\% apontaram a necessidade de mudança nas escolas. (ANDI. 2001. p.28)

Todas as soluções apresentadas foram unilaterais e não levaram em consideração mudanças na estrutura da organização da sociedade para melhorar as condições de humanização.

Os principais padrões veiculados pelos meios de comunicação são aqueles de interesse da elite dominante. Essas pessoas são vistas como "inteligentes", "belas", "importantes". Com o intuito de regular condutas, figuras supostamente anti-sociais são mostradas para desqualificar transgressões como eventos contra e fora da "ordem". (SALES. 2004. p.85)

Em nome da normalização e do poder disciplinador os "loucos", "criminosos", os "diferentes" são transformados em coisas, coisas para se ver, temer. Despersonalizados eles se transformam no contra-exemplo, ou seja, o exemplo que ninguém deve ter por perto. Essa visibilidade pervertida tem a intenção de produzir medo aos que não cometeram delitos.

O Estado moderno serviu-se [...] largamente deste artifício a disseminação do medo aliada à personificação do crime e da criminalidade em certos indivíduos, grupos sociais ou frações de classes, elevando-os à condição de metáforas da violência, caso emblemático dos adolescentes infratores no presente. (SALES. 2004. p.146)

A mídia prolifera discursos normativos e modelos de conduta. Captura as falas dos agentes e devolve ao grande público modificado-as, extraindo do contexto em que foram produzidas, destruindo o caráter histórico de determinadas produções. Exerce um poder de criar no imaginário da população uma maneira de ver os adolescentes pobres - sempre como seres violentos e a quem se devem temer.

A divulgação na grande imprensa sobre a violência que envolve os adolescentes possui um caráter policialesco e repressivo. Responsabiliza as famílias dos adolescentes por sua entrada na criminalidade, apresenta soluções 
unilaterais e simplistas na resolução desses problemas e constroem mitos sobre os adolescentes pobres: estes quase sempre são apresentados como perigosos, como se o número de envolvidos em infrações fosse muito elevado e como se a legislação fosse branda e inconseqüente, sem oferecer a punição rígida adequada.

\begin{abstract}
Da mesma maneira, a violência cometida por um adolescente que integra uma família com baixa renda não pode ser encarada como um fato isolado: é fundamental analisar o impacto da exclusão de direitos elementares, como a integridade física, os serviços básicos de educação e saúde e o acesso a uma renda digna. Um trabalho jornalístico que combine tais fatores não demanda uma revolução de espaço, mas contribui de forma significativa para o entendimento do leitor, além de gerar o aprofundamento do debate público. (ANDI. 2005. p.19)
\end{abstract}

A imprensa latino-americana foi analisada e comentada pelo documento "Direitos, Infância e Agenda Pública: uma análise comparativa da cobertura jornalística latino-americana" (ANDI. 2007). Esse documento foi resultado do monitoramento de jornais diários em 10 países $^{44}$, quando o assunto era a infância e a adolescência. O objetivo era contribuir para a "[...] construção de um jornalismo mais socialmente responsável e proativo, capaz de incidir de forma efetiva nos processos de formulação de políticas públicas em favor de crianças e adolescentes." (ANDI. 2007. p.4)

Os dados levantados referem-se ao ano de 2005 e as conclusões foram semelhantes às encontradas nas pesquisas anteriormente citadas e que se referiam apenas ao Brasil.

Houve um percentual significativo de textos sobre infância e adolescência, o que indicou uma preocupação da sociedade com esse assunto, porém a qualidade das notícias deixou a desejar. A maioria delas apresentava fatos descontextualizados, não havia dados estatísticos mais gerais que apoiavam as discussões, não foram mencionadas políticas públicas para o setor, indicadores sociais ou legislações específicas.

\footnotetext{
44 Argentina, Bolívia, Brasil, Colômbia, Costa Rica, Equador, Guatemala, Nicarágua, Paraguai e Venezuela.
} 
As notícias não apresentavam um perfil investigativo, com denúncias de violação de direitos e apresentação de solução para os problemas. Não compararam dados, não resgataram eventos do passado, não apresentaram versões e opiniões divergentes sobre o mesmo assunto.

Dessa forma a mídia reforçou a visão de que as questões de violação de direitos humanos envolvendo crianças e adolescentes não possuem relação com questões sócio-econômicas. E fortaleceu, no imaginário social, a visão de que a violência contra ou praticada por crianças e adolescentes é um "caso de polícia". 
Capítulo 11 - APROXIMAÇÃO O RESGATE DE CADA UM 


\section{APROXIMAÇÃO - O RESGATE DE CADA UM}

"[...] A fonte da liberdade está no nascimento de cada homem e na sua capacidade de começar de novo.[...]" (ARENDT. 2004. p.518)

A justificativa de que os adolescentes entram no mundo do crime porque suas famílias são "desestruturadas" mantém um discurso ideológico de como "deve ser uma família", ou seja, qualquer outra formação familiar diferente de pai, mãe e filhos vivendo na mesma casa seria considerado uma aberração produtora de "desordens". Esse tipo de pensamento, mais uma vez, determina que a entrada de um adolescente na criminalidade deve-se a questões individuais, o que na verdade, está corroborando a lógica da produção de poder em cima do corpo e do pensamento do outro.

Sabe-se que uma criança pode receber os cuidados necessários para o seu desenvolvimento físico, mental e emocional por qualquer adulto que desempenhe os papéis de cuidado, carinho e orientação.

"A justificativa da "família desestruturada" como responsável pela escolha do crime perpassa quase todos os discursos [dos representantes do Estado]. Eximem o Estado e a sociedade, ou seja, o problema é individual, e a responsabilidade é do meio, especialmente da família." (FEFFERMANN. 2006. p. 131)

Com certeza o fenômeno não é individual. A responsabilidade é de toda a sociedade.

Os jovens participantes dessa pesquisa relataram que, em suas famílias, não há outras pessoas com passagens pelo sistema Febem/Penitenciária.

Dois deles, Lucas e Breno, foram criados em instituições que abrigam crianças e adolescentes. Lucas mantém contato com seu irmão e como afirmou no trecho abaixo, este nunca cometeu infração. Breno relatou não conhecer irmãos, apesar de achar que os têm. 
Segue trecho das entrevistas em que os jovens afirmam que seus irmãos não cometeram atos infracionais.

Lucas

Eu praticamente, eu fui criado sem família, eu fui criado, eu e meu irmão, sozinho e tipo, meи irmão ele foi um guerreiro, porque tipo... depois que a gente saiu disso tudo, ele... que estava no SOS Criança que ele era menor, né? A gente... depois disso tudo, ele tipo, foi servir o exército, hoje ele... depois ele saiu do exército, hoje ele trabalha com restaurante, entendeu?

[Ele nunca passou pela Febem?] Nunca passou pela Febem, ele, sabe? Teve mais cabeça do que eu... mesmo eu sendo mais velho, ele teve mais cabeça do que eu.... ele não se deixou levar.(Lucas)

\section{Douglas}

[E você tem quantos irmãos?] Tenho 3 irmãos, eu sou o caçula, isso. [E os outros são casados, têm filhos?] Os outros são casados. [Alguém passou pela mesma experiência que você? Ninguém foi preso? Ninguém passou pela Febem?] Não, não...

Alex:

....tenho dois irmãos, um irmão e uma irmã, casados já, tenho 4 sobrinhos, mas aí eu já estou adiantando....(...) ...Então, mas é isso, mas a convivência com a minha mãe está super bem, super boa, assim, ela está super feliz, super feliz, ela fala de mim, assim, pra qualquer pessoa com muito orgulho de..., mas ela não fala que eu já passei pela Febem, essas coisas, mas ela fala com muito orgulho que.. que é eu que cuido dela porque meus irmão estão casados...

Uma pesquisa coordenada por Assis (1999) ajuda a pensar as condições que levaram alguns adolescentes, mas não seus irmãos ou primos, a cometerem infrações. O levantamento de dados foi feito com 92 jovens do sexo masculino, moradores das cidades do Rio de Janeiro e do Recife, durante o ano de 1997. A autora ressaltou que esses dados não têm caráter conclusivo e que seriam necessárias novas investigações. A pesquisa levantou condições sociais, comunitárias e individuais que apareceram nas histórias de vida dos jovens entrevistados, para serem comparados entre os dois grupos.

O mérito de uma pesquisa desse tipo é de aprofundar o conhecimento sobre o fenômeno da prática infracional e não deve servir para comparar indivíduos, situações ou estabelecer pré-condições que gerem criminalidade. A 
violência, como vem sendo discutida ao longo dessa dissertação, é um fenômeno complexo, historicamente determinado e que não deve ser analisado unilateralmente.

O objetivo da pesquisa denominada "Traçando caminhos numa sociedade violenta: a vida de jovens infratores e seus irmãos não infratores" foi de "[...] analisar a história de vida de jovens que praticaram atos infracionais considerados graves e de seus irmãos que não cometeram atos violentos." (ASSIS. 1999. p.9).

Para tanto, investigou a trajetória de vida de jovens que cometeram atos infracionais graves (homicídio, assalto à mão armada, lesão corporal, estupro, atentado violento ao pudor e tráfico de drogas) e seus irmãos/primos não infratores, buscando conhecer os fatores de risco e de proteção para a delinqüência.

Procurou também aprofundar o conhecimento sobre a realidade familiar, comunitária e social destes jovens enquanto fatores importantes para se compreender o direcionamento de alguns para o caminho da infração. Além disso, investigou a participação dos setores públicos responsáveis pelo atendimento ao adolescente que cometeu ato infracional.

A partir da pesquisa a autora levantou alguns aspectos que considerou importante.

$\checkmark \quad$ a maioria dos entrevistados pertencia a famílias de baixo poder aquisitivo;

$\checkmark \quad$ os jovens conviviam diariamente com a violência policial e do tráfico de drogas;

$\checkmark \quad$ o nível de escolaridade era baixo, porém um pouco mais elevado para os irmãos e primos $(70 \%$ de todos os entrevistados tinham abandonado a escola para trabalhar ou por desentendimentos na instituição de ensino);

o grupo de amigos dos infratores restringia-se a pessoas que estavam inseridas na criminalidade, enquanto seus irmãos e primos tinham um círculo de amizade mais ampliado; 
$\checkmark \quad$ a maioria dos que tinham cometido ato infracional relataram ter como lazer principal o baile funk, inclusive pela violência praticada ali;

$\checkmark \quad$ a maioria dos que tinham cometido infração relatou uso frequente de drogas, o que não foi verificado para seus irmãos e primos;

$\checkmark \quad$ todos os entrevistados relataram alta rotatividade nos relacionamentos afetivos e pouca preocupação com as Doenças Sexualmente Transmissíveis e gravidez indesejada, sendo essas, uma preocupação maior dos jovens que não cometeram infrações;

$\checkmark \quad 90 \%$ dos entrevistados já tinham trabalhado em bicos que não necessitavam elevado grau de instrução e que remuneram pouco (ajudante de pedreiro, balconista, oficina mecânica, feirante, auxiliar em supermercado, farmácia, padaria ou banca de jornal etc). Os que já tinham cometido infrações afirmaram já ter trabalhado no tráfico de drogas. A preocupação com um trabalho formal e com carteira assinada ocorreu no grupo dos jovens não infratores;

$\checkmark \quad$ os jovens que não cometeram infrações relataram aproveitarem mais as oportunidades de trabalho;

$\checkmark \quad$ as condições adversas da vida tornaram os que não cometeram infrações mais responsáveis e com uma visão mais crítica sobre a comunidade e sobre seus direitos;

os adolescentes que cometeram atos infracionais relataram quererem consumir roupas de grife como prioridade para o uso do seu dinheiro; $\checkmark \quad$ todos relataram como plano para o futuro arrumar um emprego, sendo que os adolescentes que não tinham cometido infrações ambicionavam melhores trabalhos;

$\checkmark \quad$ todos demonstraram ter uma visão positiva de si mesmos, porém os que não infracionaram sentiam-se mais valorizados;

$\checkmark \quad$ ficou evidente na pesquisa a ausência de redes sociais de apoio aos jovens e descrença no que já existe, como escolas e poder judiciário; 
$\checkmark \quad$ em relação as relações familiares, a autora verificou que entre os adolescentes que não tinham cometido atos infracionais houve uma maior convivência com seus pais quando criança e, ao contrário, uma maior instabilidade nos cuidados iniciais com os que tinham cometido infração, além de um distanciamento maior destes com a família ampliada;

$\checkmark \quad$ os adolescentes que cometeram atos infracionais mantinham uma imagem mais idealizada da família; os que não cometeram infrações demonstraram maior capacidade de lidar com perdas familiares e de estabelecimento de vínculos mais fortes; as famílias possuíam menos controle sobre a vida dos que chegaram a cometer infrações do que os que não o fizeram; os que cometeram infrações eram os caçulas protegidos;

os irmãos e primos identificaram-se como pessoas mais tranquiilas enquanto relataram que os parentes que entraram na criminalidade eram mais arrojados e valentes;

$\checkmark \quad$ os que cometeram infrações mostraram-se mais questionadores em relação às dificuldades da vida, enquanto seus irmãos e primos eram mais conformados;

$\checkmark \quad$ os que infracionaram relataram não conseguirem conter sua agressividade, independente das consequiências, enquanto seus irmão e primos temiam represálias por seus atos;

$\checkmark \quad$ os jovens que não cometeram infrações demonstraram maior introjeção de limites e eram mais resilientes às adversidades da vida, apesar de terem sido marcados por elas.

Segundo a pesquisa (ASSIS. 1999), os adolescentes que cometeram atos infracionais relataram diversos motivos para entrarem na criminalidade.

Os que praticaram homicídios afirmam que a morte da mãe ou doença do pai e o desejo de comprar roupas de marca e objetos de consumo foram os motivos principais. 
Os que roubavam relataram como motivos importantes a revolta por terem sofrido injustamente; a solidão por perda de parentes; o ócio, o desejo de aventura e a vontade de ter uma arma.

Os que entraram no tráfico de drogas afirmaram ser importante para eles sentirem-se poderosos na comunidade; respeitados pelos outros; conseguir mulheres; adquirir dinheiro para consumir roupas e armas. Estar sem fazer nada e ter parentes envolvidos no tráfico também foram motivos relacionados pelos jovens para sua entrada na criminalidade.

Maria de Lourdes Trassi em Adolescência/Violência: desperdício de vidas (2006) apontou alguns motivos para que adolescentes entrem na criminalidade, entre eles a necessidade de dinheiro para ajudar a família, a virilidade masculina, o fascínio pela aquisição de bens de consumo e a mais importante, a visibilidade e o poder conquistados pela entrada na malandragem.

Marisa Feffermann, em seu texto Vidas Arriscadas (2006) expõe os motivos que levaram os jovens a entrarem no tráfico de drogas: por status, para poder consumir droga, porque era a única opção disponível, para comprar comida em casa, porque não encontraram emprego ou simplesmente não sabiam por que entraram.

E a autora chama a atenção: "A necessidade de serem reconhecidos, o desejo de pertencer a um grupo, a busca pelas promessas da indústria cultural, a própria condição juvenil e a aventura de correr risco são alguns fatores de impulsão para o tráfico". (2006. p. 239)

Feffermann afirma também que a sociedade que não cumpre a promessa de igualdade para todos leva as pessoas a buscarem o que almejam através das armas que têm, e isso inclui os crimes e contravenções.

Alguns estudos como (Zaluar, 2004 e Spagnol 2005) citados por Peres, Cardia, Santos. (2006. p.31) falam da entrada na criminalidade por envolvimento com quadrilhas e bandos. Não parece ser o caso dos jovens entrevistados, pois eles não relataram participar de grupos formais dentro da 
criminalidade. Porém essa diferenciação mostrou-se bastante tênue pelas falas dos jovens:

Alex relata participar dos assaltos sempre em grupo - pequeno e em vias de se profissionalizar no crime.

Bom, o segundo assalto, o segundo assalto também foi o mesmo grupo, só que numa, só que foi mais reduzido, a gente fomos em quatro pessoas pra Av. Paulista, e nisso foi uma saidinha de banco.

(...)

eu não sei como a gente teve essa idéia de combinar tudo antes, porque eu não lembro de ter ninguém com experiência nisso, que estava junto com a gente, saiu do grupo, eu não sei se tinha amigos da gente que deu essa... essa idéia, mas eu acho que foi isso, de alguma forma essa idéia veio de outra pessoa, de outra pessoa fora do grupo, que deu a idéia pra gente de combinar tudo certinho antes de.... de chegar pro assalto. Bom. Isso foi na Paulista..

(...)

o mesmo.... o mesmo grupo é, não, não era mais o mesmo grupo, só que eu tinha convivência com o mesmo grupo, só que nesse dia que eu fui assaltar, não era com o mesmo, com o mesmo grupo... e aí tinha o Al. e tinha um cara alto, que era de maior, com nós... esse alemãozinho ele chamava D., D. era meu parceiro assim de ... de assalto, de... de droga, de...conviver sempre junto assim, depois que eu saí, né? Foi... depois que eu saí da Febem, eu já conhecia ele de vista, mas a gente nunca tinha feito assalto junto e aí a gente foi pra esse assalto lá no Banco... (Alex)

Douglas fala da presença do PCC (organização denominada Primeiro Comando da Capital) o tempo todo em sua trajetória e sua escolha pessoal em não entrar para o grupo.

que nem eu já freqüentei reunião tudo, mas eu era Primo Leal, né? E... não era do Comando...(...) [Se você era do Comando, agora não está mais nessa vida, não quer mais....] Não pode sair mais, só por excluimento.... [E que vantagem você leva em se associar ao Comando?] É... pra falar a verdade... no meu modo... sempre pensei não leva a nada.... que você leva que você tem mais uma liberdade na cadeia, que nem, o que acontece? Pra população é chuveiro mesmo gelado, agora na faxina, no esporte, é chuveiro quente, chuveiro ali é elétrico mesmo, o resto da cadeia é chuveiro gelado, é... faxina... o esporte onde fica os irmão, o pessoal que é mais associado com os irmão, que pode ficar solto... o esporte pode ficar solto até às 5, daí o esporte é trancado, depois só fica os faxina solto até as 9 horas da noite (Douglas)

Lucas relata ter preferência por realizar as infrações sozinho, pois assim não correria riscos por trairagem ${ }^{45}$.

\footnotetext{
${ }^{45}$ Traíra é a pessoa que delata a outra. Entrega para a polícia ou para grupos rivais.
} 
Sozinho, nunca gostei de ir com alguém porque era, eu achava que era trairagem, porque se você pegasse uma coisa alta, aí um podia ser traíra com o outro, que nem acontece várias ocasiões que um chega a matar o próprio amigo por causa do dinheiro, então eu comecei a roubar sozinho, comecei a roubar e tudo e foi nisso que eu acabei sendo preso com....(Lucas)

Os jovens entrevistados nesse trabalho alegaram motivos semelhantes aos citados pelas autoras para a entrada na criminalidade. Abaixo destaco alguns motivos alegados pelos jovens dessa pesquisa para terem começado a infracionar, que não foram mencionados em outros capítulos:

\section{A adrenalina}

Bom, e a gente assaltou com uma arma de brinquedo... era... uma 765 que... é uma.... a gente chamava de quadrada, não mas era uma 765 e era de plástico e era azul ela... só que dava pra saber que era de plástico, só que o que a gente fez, a gente pintou ela de preto... pintou de preto pra disfarçar pra gente poder assaltar aquele mercado.... e.... aquilo eu acho que... se tornou fácil demais na primeira vez... virou uma coisa instigante assim, de adrenalina.... de todo aquele grupo reunido, acho que a gente tinha sete, sete meninos assim adolescente que em vez de jogar bola é... partir pra outras brincadeiras...

(...)

... a gente acabou tomando o revólver dele e assaltando a lotérica, a gente mandou todo mundo pro chão, tinha umas pessoas muito com medo, já chorando, gritando, a gente pediu pra elas ficarem quietas, mas mesmo assim a reação das pessoas era... era extremamente amen..., amedrontosas enquanto a gente tava fazendo uma coisa assim... que pra nós já tinha virado diversão, já era como roubar doce de criança, mesmo que ela grite, você pega o doce e sai correndo (rsss) e não liga pra ela, assim... (Alex)

\section{A falta de diálogo na família:}

Eu tinha é... 14, 15, 15 anos, daí ela pensou, ela e meu irmão mais velho pensou que eu ia catar a moto pra ficar zoando, aprontando por aí pela rua, dai ela falou "não vou te dar!", que não sei que, daí eu acabei discutindo com minha mãe, com meu irmão, também não quero mais nada de ninguém, não quero saber, "já que vocês não vão me ajudar então eu vou me ajudar do meu jeito, vocês não podem me arrumar o dinheiro, então eu arrumo do meu jeito". Aí eu comecei a roubar, conhecia já amigos meus que roubavam, comecei a roubar, né? Ia no supermercado, tudo.... (Douglas)

\section{A falta de orientações}

A vida acaba criando você desse jeito, a rua, entendeu? Às vezes, um adolescente, o que ele quer, ele quer um pouco de atenção, se você que nem... nessa época, tudo, eu vendi drogas também na rua, tinha biqueira que 
(...) mesmo tendo meu próprio ponto, então o que acontece, é.... às vezes chega um adolescente que você.... chega ali ele está com problema dentro de casa e às vezes o que ele recebe mais um carinho, um conforto é do cara que tá na biqueira, que está ali na droga, então o que acontece, chega ali "não, o que foi, senta, vamos conversar, não, mas isso é coisa que acontece..." sempre está colocando a pessoa pra frente e vai puxando mais a juventude pro lado dele. (Douglas)

[Me diz uma coisa, o que você acha que leva esse povo todo a cometer infração, aí.. a entrar nessa vida?]Pra ser sincero.... eu.... eu fui... porque.... eu vi aquela revolta dos meus pais e assim, de uma certa maneira quando eles se separaram, meu pai não ganhava tanto pra, pra sustentar e aí começou a atrasar algumas coisas e aí eu queria ajudar de alguma forma, mas eu não conseguia trabalho, né? Eu não sabia por onde procurar um trabalho, não tinha um conhecimento...não tinha alguém que chegasse pra mim "oh, é... tem um trabalho aqui, vai lá, procura, e aí tinha uns meios mais fáceis, assim, que eu já conhecia, eu acho que é por isso, mas é... o que leva, o que leva mesmo, eu acho que é a convivência, a necessidade, dependendo da pessoa e..... eu acho que é isso, a convivência e a necessidade e a vontade de.... de assim, de ganância de ter o seu próprio dinheiro, assim, de ver algumas pessoas com carro, moto, com dinheiro fácil.... e você ter aquela ganância de, de ter pra você....De ter coisas, essas coisas, da maneira mais fácil possível, mas... depois você cresce, amadurece, sabe... sabe que não é dessa maneira. (Alex)

\section{As amizades}

[Você tem idéia do que leva elas a roubar?]

Amizade! Amizade... amizade... amizade e liberdade da mãe e do pai, tipo, pode sair, pode fazer o que quiser, tudo começa no baile, né? Vai a primeira vez num baile, aí faz a segunda vez, você vai pegando amizade, amizade, amizade, quando você vai ver... "ah vamos ali fazer não sei que”, aí você faz a primeira vez dá certo, faz a segunda vez dá certo, aí você não pára mais, enquanto você não... não vê aquele objetivo: você morre ou vocêe sobrevive e vai preso, você.... (Lucas)

É... amizade, amizade, amizade que ele se deixou levar... ele se deixou levar... não só ele como várias pessoas, esse negócio do governo aí que tem... de compra não sei do que lá.... corrupção envolvendo dinheiro... entendeu? É um querendo pegar do outro entendeu? Querendo derrubar o outro... então as pessoas sabem o que estão fazendo, mas.... (...) É.... é se você tiver uma inspiração, se você falar, não eu quero isso! Se você não tiver objetivo nenhum você vai fácil, entendeu? Você vai fácil! Fala, ah isso daqui não vai me dar futuro, eu não vou conseguir mais nada então demorou, entendeu? tipo objetivo, vai você vê o carro, você vê um carro na rua, vê um carro na televisão... você vê tipo a pessoa dirigindo, você não tem um carro, o que você quer fazer? Puta! Quero ter um carro! Entendeu? Quero ter um carro, quero andar de carro, qual que é o seu objetivo? Trabalhar pra comprar aquele carro, é a mesma coisa entendeu? Ou senão a pessoa, vou roubar pra comprar aquele carro, entendeu? Cada um vê com uma visão diferente, entendeu? É isso que é o ver... (Lucas) 
O desejo de sentir adrenalina, a necessidade de ter seu próprio dinheiro para consumo, a ausência de uma possibilidade de trabalho, o desejo de receber orientações de um adulto etc. Essas são razões que marcam o encontro do indivíduo com a sociedade. Será que nesse caso não foi um choque duro ou invés de um encontro?

Os adolescentes pobres das grandes cidades são desrespeitados em seus direitos básicos: moradia, saúde, educação, cultura, lazer, convivência familiar e comunitária. Seus direitos são também desrespeitados por aqueles que deveriam garantir a ordem e a vida: a corrupção e violência policial. Essas condições refletem sua inserção em uma determinada classe social.

Os adolescentes que cometem ato infracional estão buscando, de maneira precária e ilícita, serem incluídos no sistema. Incluem-se na lógica ampliada do capital como consumidores. Sentem-se ideologicamente incluídos e estão juridicamente incluídos. São cidadãos com direitos políticos. Podem comprar, vender, responder um processo, podem até serem internados em instituições ditas socioeducativas. Quando cometem uma infração estão afirmando a lógica dessa sociedade que produz cidadãos de segunda, terceira, quarta categoria.....

$\mathrm{O}$ ato infracional dos jovens, como uma tentativa de sobrevivência nessa sociedade que vitimiza enorme parcela da população, não é uma tentativa que produza transformações no status quo, mas é uma forma da sociedade inteira comprometer-se com a população, cujo sistema exclui das riquezas do capital. O problema não é apenas dos jovens que foram para a Febem, mas de toda a sociedade que corrobora com esse sistema hipócrita. Apesar das pessoas negarem, isso se torna evidente quando eles fazem rebeliões...

A exclusão abrange a todos, os que vivem processos de exclusão e também os, assim chamados, incluídos - ela coloca todos diante da desumanidade causada pelo processo de produção capitalista. 
A sociedade da promessa da integração no princípio do contrato e da igualdade vem se firmando como a sociedade da incerteza e do medo. Não o medo da violência que mata (...) Mas o medo de se tornar ninguém e coisa alguma, de ser descartado e banalizado, o medo daquilo que não se vê. Isso é de fato, por inteiro, a exclusão social. É inconsistente reduzir a exclusão à pobreza material (...) A pobreza nem sempre é exclusão e a pobreza de fato excludente é apenas o pólo visível de um processo cruel de nulificação das pessoas, descartadas porque já não conseguem submeter-se à contínua ressocialização que delas faz apenas objeto de um objeto, instrumento de um processo social de produção de riqueza que passou a usar as pessoas como se elas fossem apenas matéria-prima da coisa a ser produzida, como se fossem objeto e não mais sujeito (MARTINS. 2003. p.20)

A condição humana proposta por Hanna Arendt (1997) prevê a necessidade de visibilidade com a possibilidade da existência de outros que enxerguem o primeiro como sujeito, com sua forma de ser e agir livre de preconceitos e interesses.

Foi no encontro com outras pessoas, que confiaram neles e que realmente estiveram do seu lado que os jovens entrevistados relataram terem conseguido mudar sua forma de pensar e parar de cometer infrações. "Esta qualidade reveladora do discurso e da ação vem à tona quando as pessoas estão [desinteressadamente] com outras [...]” (ARENDT. 1997. p.192)

[...] Não foi como eventuais assassinos, ladrões ou traficantes que as suas ações ganharam relevo. Foi justamente no momento em que transcenderam o lugar comum das suas vidas e imprimiram um sentido coletivo (deliberado ou inconsciente) para a sua ação, que ajudaram a escrever um novo capítulo da história da visibilidade dos adolescentes infratores, das suas necessidades, desejos e direitos. (SALES. 2004. p.255)

Quando penso nos adolescentes pobres que são vistos pela sociedade como perigosos, independente do que façam; que não podem opinar, pois não serão ouvidos ou só quando cometem uma infração é que passam a ser olhados por todos, percebo que seus direitos humanos estão sendo profundamente desrespeitados, muito mais que o seu direito à educação, à saúde, ao lazer.

Os adolescentes pobres estão impedidos em sua existência humana. Impedidos de falarem, de agirem de se relacionarem com outros humanos. 
"[...] o direito de cada indivíduo de pertencer à humanidade, deveria ser garantido pela própria humanidade.”(ARENDT. 2004. p.332)

Os homens não nascem iguais, aliás, a diversidade é a característica principal dos seres humanos. Porém a igualdade almejada por todos - de condições políticas, de usufruto das possibilidades da vida - é uma conquista de algumas culturas em que a justiça entre os homens pode prevalecer.

“[...] Não nascemos iguais; tornamo-nos iguais como membros de um grupo por força da nossa decisão de nos garantirmos direitos reciprocamente iguais." (ARENDT. 2004. p.335)

A ideologia dominante propaga igualdade de condições, de oportunidade, de felicidade no consumo, como se todos fossem iguais. Propaga também a promessa de que um dia, no futuro, todos terão a mesma oportunidade. Mas na realidade, massifica a todos para que ajam e pensem da mesma maneira.

A igualdade de condições políticas não deve massificar a todos, transformando-os em cópias de um só. Cada ser humano nasce diferente do outro e carrega dentro de si a possibilidade de um novo começo a cada ato. A riqueza da possibilidade de convívio humano está no respeito às diferenças, na convivência com o diferente.

[...] O paradoxo da perda dos direitos humanos é que essa perda coincide com o instante em que a pessoa se torna um ser humano em geral - sem uma profissão, sem uma cidadania, sem uma opinião, sem uma ação pela qual se identifique e se especifique - e diferente em geral, representando nada além da sua individualidade absoluta e singular, que, privada da expressão e da ação sobre um mundo comum, perde todo o seu significado. (ARENDT. 2004. p.335 e336)

Os adolescentes que cometem um ato infracional revelam, através da infração, seu rosto, sua existência, seus anseios etc. Nesse momento ele passa a ser visto pelos outros como alguém com individualidade própria, com capacidade para agir e proporcionar algo novo, inédito. Porém, cometer um ato infracional o faz pertencer a uma classe de pessoas que os outros não querem ter por perto. Sentem medo e até repugnância. 
“[...] Somente na relação concreta de ajuda entre seres humanos é que há humanização." (ROMAN. 2007. p.88) e eu acrescentaria, somente nessa relação é que pode haver aprendizagem.

$\mathrm{O}$ ato infracional é uma tentativa revolucionária de romper com a violência da tradição de expropriação que vive, buscando nas origens dessa a sua base de apoio para estar no mundo, buscando as relações humanas perdidas, transformadas em objetos no ciclo contínuo da acumulação do capital. O ato revolucionário é violento, o sujeito expropriado violenta o outro. Esse que representa para o adolescente sua não possibilidade, seu não pertencimento, sua não humanidade.

Os adolescentes que buscam mudar sua relação com o mundo estão atrás de relações humanas que não os violentem e onde eles também não sejam violentos. Nas falas dos quatro jovens entrevistados podem ser percebidos momentos em que o encontro com o outro, que confiasse neles, que os respeitasse, foram situações de resgate das experiências passadas, momentos em que foi possível buscar novas possibilidades para o futuro. As mudanças começaram na busca pela sua humanidade perdida.

[...] fluindo na direção da morte, a vida do homem arrastaria consigo, inevitavelmente, todas as coisas humanas para a ruína e a destruição, se não fosse a faculdade humana de interrompê-las e iniciar algo novo, faculdade inerente à ação como perene advertência de que os homens, embora devam morrer, não nascem para morrer, mas para começar. (ARENDT. 1997. p.258)

Alex e Lucas falaram dos cursos de vídeo (Associação Novolhar) que fizeram quando cumpriam uma medida socioeducativa de internação e semiliberdade, respectivamente. Lucas relata sua opinião a respeito da importância dos cursos para os jovens não cometerem infrações.

Breno falou da oficina de cerâmica que fez quando estava em abrigos do SOS Criança ${ }^{46}$. Douglas falou de um curso de teatro que fez na Associação

\footnotetext{
${ }^{46}$ SOS Criança foi uma instituição vinculada a Febem-SP, responsável pelos cuidados das crianças abrigadas. Na época, os chamados "carentes".
} 


\section{Mutirão, ao mesmo tempo em que reclama da distância dos cursos oferecidos apenas nas regiões centrais da cidade e que acha importante na vida dos adolescentes que moram nas periferias.}

[...] e aí surge a Novolhar, a Novolhar foi, tem.. foi a ONG que... que me direcionou quando eu saí.... o Paulo Santiago, ele me ligou, que é o... acho que é o coordenador da Novolhar, coordenador da Novolhar até hoje e aí ele me ligou e falando, e eu já tinha feito o curso lá em Franco da Rocha, já tinha terminado, já tinha ganhado até diploma lá, tenho até a foto........] foi, foi super legal, eu gostei do curso, e aí quando eu saí, eu já queria parar assim, mas.... eu não tinha uma direção assim... eu não sabia por onde começar... e eu acho que foi a Novolhar que me deu a direção, assim, de um curso, de saber que tem... tem caminhos, de saber que tem oportunidades também... que não é só... é... tipo....que não era só aquela vida que eu tava vendo que existia, tinha outras à minha volta, tinha outros mundos, tinha outros, outras, outras convivências.... .(Alex)

E eu não me interessava por nada, queria ficar o dia todo lá soltando pipa, pegando pipa e jogando bola... e só pensando em maldade e aí nisso apareceu uma oportunidade de eu fazer um curso na Novolhar, de televisão, é.. Rádio e Televisão. (...)É, então...daí foi essas oportunidades, entendeu? Foi as oportunidades que foram surgindo, pra mim não ter esses pensamento, entendeu?

(...)

eles vão dormir na semiliberdade e vão pra lá fazer o curso.... isso eu acho bom, isso é uma coisa que começou agora em... 2004, alguma coisa assim... 2003, 2005... não me recordo muito bem, eu fui com o Paulo lá, mas... foi coisa rápida... então, isso eu acho bom... isso é um... tipo, isso é uma coisa pro menor, pro adolescente não ficar com os pensamentos de ficar querendo fazer furto ou matar alguém... e isso, e tipo pra ter um futuro pra eles, entendeu? (Lucas)

[E a cerâmica você aprendeu onde? Onde você...] Eu comecei no Liceu, na verdade eu tinha feito uma oficina na New Ac, que é uma casa, que era a central da casa de onde eu morava, e eu fiz uma oficina assim muito rápida e eu curtia e eu já fazia, na rua por exemplo eu mexia com arame, já fazia colagem... [...] Então eu aprendi um pouquinho de cada coisa, né? Que aí eu fiz Liceu, aí depois eu fui trabalhar, aprendi várias coisas.. é, vídeo aqui.... fui fazer um monte de coisas assim, né? Eu fiz muita oficina, aprendi muitas coisas quando moleque assim e.... (Breno)

Me arrependo muito, agradeço as pessoas que me ajudaram bastante: a tia Elaine, a tia Fabiana que era monitora também, a qual aprendi a fazer teatro, essas coisas toda, só que hoje em dia falta oportunidades pros jovens da.... vamos se dizer, da Cohab, né? Moradias do bairro... porque hoje em dia muitas pessoas arrumam coisas assim,, mas lá pro lado de Santana, Centro... longe, que é pra pessoas que têm dinheiro, pra jovens que têm dinheiro e os jovens que não tem dinheiro, que são 
pobre, não tem dinheiro pra onde sair.... pra ter um espaço pra ele, tipo um centro cultural onde você pode, onde você pode ali tá adquirindo sabedoria, fazendo teatro, pessoas ali ensinando, é.... dança, esses negócio, não tem incentivo na comunidade, então onde que tem tão a procura de que? De montar uma comunidade pra ganhar dinheiro, nas costas dos adolescentes $e$ jovens que está freqüentando ali, então que falta muito isso, que eu acho que... eu penso assim, não sei se estou certo, fico pensando... porque eu acho que se tivesse isso... o adolescente precisa ocupar a mente com essas coisas, acho que ele tinha menos tempo de ocupar com crime, na malandragem, no meio da rua, que é na rua que você aprende isso tudo, você aprende, você adolescente.... (Douglas)

A ação move o homem para um recomeço e é isto que os meninos precisam para que a infração não seja a única forma de estar no mundo.

“[...] Para a confirmação da minha identidade, dependo inteiramente de outras pessoas [...] O que torna a solidão tão insuportável é a perda do próprio eu, que pode realizar-se quando estás a sós, mas cuja identidade só é confirmada pela companhia confiante e fidedigna dos meus iguais. [...]" (ARENDT. 2004. p. 529)

Vieira (2003) em sua dissertação de mestrado "O ato infracional na perspectiva do adolescente em conflito com a lei: um estudo sócio-histórico" afirma a importância do afeto na formação do adolescente. Para tanto se baseia na experiência de vida de um adolescente que cumpriu uma medida socioeducativa na Febem de São Paulo. Relata que os maus-tratos e humilhações sofridas pelo jovem o transformaram em ladrão. O próprio indivíduo, vivenciando uma rotina de maus-tratos por parte de quem deveria cuidar e sentindo-se apoiado por adolescentes envolvidos com a criminalidade, passou a pensar e agir como se espera no mundo do crime.

O adolescente, sentindo-se acolhido pelas pessoas envolvidas na criminalidade começa então a perceber o respeito de que poderia desfrutar caso assumisse o papel de ladrão [..] o adolescente encontraria o reforço decisivo para assumir este significado social e historicamente construído, transformando-o em um sentido pessoal e subjetivo. (VIEIRA. 2003. p.149)

O mesmo autor informa que para sair do lugar de "ladrão", como inclusive era chamado pelos funcionários da instituição, necessitou de novas referências e novas formas de encaminhar sua vida. Concordo com o autor 
quando esse afirma que para sair do mundo do crime tornam-se necessárias novas perspectivas de vida e apoio de adultos que possam servir como referência na nova caminhada.

Refletindo sobre essa experiência podemos afirmar que os adolescentes que estão internados na Febem precisam "andar conforme as regras", tanto as que foram estipuladas pelos internos, como as que são fruto da instituição. Se a pessoa não se "enquadrar" ela sofre mais humilhações e maus-tratos. Ou seja, o jovem precisou aprender a andar, falar, agir e até pensar como um "ladrão", mas não necessariamente tenha se tornado um.

Veja a fala de Alex sobre como precisou se "adaptar" para não ter problemas dentro da Febem:

Eu não quis fugir porque eu queria cumprir, cumprir pra ver se eu melhorava, eu já tava pensando em melhorar porque aquilo já não... já não tava me agradando, assim, mas mesmo assim, na convivência com os caras eu era de um jeito só que com o pensamento de outro, assim, eu era de um jeito que era aquele cara marrudão, meio bravo, mente psicopata, assim (rsss) pra que.... a convivência fosse melhor com, com os outros, assim...mas minha consc... mas meus pensamentos não falava pra ninguém, mas era de melhoria. (Alex)

$\mathrm{Na}$ minha trajetória profissional vivenciei uma experiência muito interessante. Após a inauguração de uma unidade de semiliberdade da Febem os educadores e técnicos reuniram-se com os primeiros adolescentes encaminhados para construírem as regras da unidade. A intenção era que com a participação de todos na construção das regras, estas seriam respeitadas e zeladas pelos próprios adolescentes.

Após algumas horas de discussão os educadores e técnicos depararamse com regras rígidas, que lembravam muito as regras defendidas por presidiários. Entre elas: não se podia tossir, espirrar ou usar o banheiro enquanto alguém estivesse comendo; para entrar e sair do refeitório era necessário pedir licença para todos etc.

Questionar as regras trazidas por alguns adolescentes em suas experiências passadas de internação foi muito difícil. Para eles, regras não podiam ser questionadas, elas foram e serão sempre assim. Não existia o 
entendimento que regras servem para organizar um determinado grupo em um determinado contexto e que podem, e devem ser questionadas e avaliadas periodicamente.

Todos os adolescentes deveriam seguir aquelas "ordens", independente de concordarem com elas. Aqueles que não seguissem eram desmoralizados e humilhados pelos companheiros. Todos tinham que segui-las, não havia escolha. Os educadores e técnicos tiveram um longo trabalho pela frente....

Nos trechos seguintes procurei destacar momentos na vida dos jovens entrevistados que serviram de apoio para mudarem sua forma de encarar o mundo e a criminalidade.

\subsection{A história de Breno}

Breno relata sua experiência de morador de rua na cidade de São Paulo. O relato sobre sua vida é confuso, disperso, arredio. A tentativa de construção da sua humanidade dá-se pela relação que ele estabelece com sua arte.

\footnotetext{
Eu tenho um ditado que diz assim: quem acha perde, entendeu? Tudo aconteceu porque eu achei uma coisa, e trouxe coisas boas, depois perdi uma coisa que eu gostava muito, mas eu tô vendo que eu tenho que achar também... [Tem que continuar procurando pra achar...] Não, não é só procurando, achar! Porque você procura, você consegue, né? Se você acha, você não está procurando, você achou, mas pensar é bom.

[...]

Acho que a gente tem que.... devagar e sempre conseguir as nossas coisas... eu tava... minha vida estava bacana, aconteceram umas coisas que eu fiquei meio intrigado e eu não sei lidar com as coisas e... tô aí, entendeu? É isso.... [...]

Acho que você tem que viver pra você aprender, não adianta ficar só perguntando, né? Eu perguntei muito e teve pessoas que ficaram quietas, por isso que eu tô... meu eu tô aprendendo que tem que ficar quieto, só isso, ficar quieto..... (Breno)
}

Breno aparenta estar vivendo uma invisibilidade total. Ele está preso a sua história fragmentada, aberta a interpretações alheias como ele sugere todas as vezes que pede para a entrevistadora descobrir por si mesma, fatos vividos por ele. 
[Você perde o.... infelizmente você perde ... às vezes você quer rever alguma coisa e.... Sua memória acontece isso de vez em quando? Você quer relembrar alguma coisa e não vem?] ... A sua acontece? [A minha acontece.] Então você se responde.... [Eu respondi por mim, queria saber por você...] Não, mas se você responde, a gente, nós somos seres humanos... (Breno)

[Você foi até a oitava série nessa escola?] Você vai pesquisar, pesquisa, já que você quer fazer uma tese, pesquisa por favor. Eu até lembro, mas é muita coisa, continua.... [Quantos anos você tinha nessa época?] Não lembro, dá uma pesquisada (risos) [Ah isso não vai dar....] Por que não, é só você ir lá, está tudo registrado, isso aí ninguém apaga, a não ser que os caras queimaram, senão tá tudo aí.... [Eles devem guardar por alguns bons anos, não sei quantos, mas acho que não guarda pela vida toda não... Só a gente mesmo que guarda as nossas histórias, os outros não.... o que vira papel, o que vira fita acaba ... pode se perder eu acho, não sei.... se a gente pega uma fita de vídeo muito antiga ela embolora...] Isso mesmo. (Breno)

Vieram atrás de mim na verdade, falaram pra eu que eu tinha que ir lá e eu fui e eu tô aí... [Quem que falaram?] Ah depois você procura, vocêé pesquisadora, pesquisa! [Ah é? (risos)] É lógico, o seu trabalho é esse, pesquisar... [Sobre a sua vida?] Não sei se sobre a minha, sobre o que você quiser... minha vida não é a melhor de todas, eu não sou melhor que ninguém, eu sou um cara simples, humilde que tô aí devagar e sempre e quero vencer, entendeu?(Breno)

Ao relatar sobre o trabalho com a cerâmica foi possível perceber uma pessoa inteira, diferente da sensação de fragmentação ocorrida no restante do tempo da entrevista.

Torna-se visível quando fala do trabalho com a cerâmica, mas ainda não se torna humano. Ele precisa da memória e da vivência com outros seres que não o julgaram, trataram como objeto ou como número em uma instituição. Breno estava vivendo na superficialidade daquele que não pode existir junto com outros humanos.

$\mathrm{O}$ adolescente que comete uma infração sofreu privações em um momento muito remoto da sua vida. Como aponta Winnicott (2005), é preciso que ao longo da vida a criança tenha passado por momentos significativos de privação nos cuidados, maus-tratos, humilhações. Tenha sofrido um verdadeiro processo de desumanização e desenraizamento. Mas antes disso, tenha tido cuidados suficientes para proporcionar a constituição de um indivíduo. 
$\mathrm{Na}$ vida de Breno o ato infracional não foi significativo. Outras situações vividas por ele e relatadas durante a entrevista pareceram ter tido maior importância. Ele sente-se sufocado pelas pessoas, por trabalhos fixos, pelos equipamentos na sala da entrevista. Sua história de vida parece não ter proporcionado a constituição de um indivíduo inteiro.

Breno parece tentar resgatar sua humanidade no trabalho com a cerâmica e na organização da sua vida quando fala para o gravador. Sem outro humano fica impossível tornar-se um. Ele sofre com sua humanidade perdida e tenta reconstruí-la. Talvez por isso tenha aceitado participar da entrevista e não a tenha interrompido, apesar dos vários momentos em que isso foi questionado.

\section{O corpo sem forma, a perda da história, o equipamento registra sua vida - a tentativa de resgate}

....e aí depois quando eu fui pra casa Pastoral do Menor, ô, pastoral não, hoje acho que é pastoral, agora é Associação de meninos, Cedeca, viche meu as coisas vão mudando....

[...]

.....olhei aquele monte de escultura e falei, é aqui que eu vou fazer, aí fiz assim alguns anos, peguei o diploma, não sei onde está, perdi o diploma, que na minha vida eu sou o cara, hoje eu tô dando mais valor às coisas, sabe assim? Tô guardando tudo, sabe assim, tudo pra mim tem uma história, tem uma parada louca agora! Mas antes tipo assim, eu já não tenho uma casa e saía andando, sabe assim, tipo a última vez que eu vi minha mãe eu tinha montado a casa tinha tudo, aí ela sumiu e eu saí andando, deixei tudo, peguei uma mochila e fui embora, entendeu? E ... é isso assim. Agora hoje eu estou dando valor pra tudo assim, a gente vai aprendendo, devagar e sempre...

[...]

.....eu sou o cara que sou, eu gosto da cerâmica, eu gosto da modelagem, eu... eu aprendi um pouquinho na madeira, mas não foi a parada doida, eu comecei pichando, aí depois aprendi um pouco de pintura, né? Grafite essas coisas... a.... e aí fui pra modelagem assim e me esbaldei com a forma, eu gosto da forma, tanto que eu vou no museu e fico pirando na forma, pego, os caras falam "meu, não pode pegar!" eu pego, é uma coisa louca assim, entendeu? Eu gosto de pegar, apertar assim! É uma coisa, tipo, sei lá, é eu, sai de mim... e... eu gosto da forma, manja? (risos) É muito bom!

[...] Firmão, é eu acho que... sei lá, não é só do barro não, eu gosto muito do barro porque o barro... ele.... ele tem forma sabe assim? Ele tem vida... ele é que nem a gente, ele lembra das coisas sabe? Manja? [...]... é como se fosse uma pessoa, só que é da natureza (risos) quer dizer, as pessoas são da natureza e é isso.... 
$[\ldots]$

...Não, nada tá me fazendo mal, é só você falar essa coisa aí de voltar pra rua, essas coisas, que você não deve pensar nisso cara! Sabe assim, é positividade, é coisas boas. Acho que todo mundo deve viv..., deve pensar coisas boas, tipo eu por exemplo acredito muito na palavra, sabe assim, nas pessoas e... é por isso que eu tô aí cara, eu acredito, é acreditar e ter fé, eu tenho fé.

[...]

Não sei se fixo, acho que o freela é bacana também, só que tem que arrumar um freela que, né? Tipo... sei lá, acho que o negócio é fazer um pouco de cada coisa assim, sabe? Devagar e sempre, nunca... é bacana um fixo, é bacana um fixo, só acho que depende do fixo também, que tem fixo que te sufoca...

[...]

....Fazer coisas boas, eu tipo assim ó, eu já roubei, eu já fiz várias coisas, só que quando eu fiz as coisas erradas na hora, tipo assim, não foi no mesmo dia ou na mesma hora, mas depois veio, foi errado, sabe assim? E eu aprendi que o negócio é, mesmo que você peça, oh por favor me dá? [...] e..... tipo.... só vivendo, sabe assim? Só devagar e sempre na pegada.

$[\ldots]$

Muita! Demais e eu não, tipo assim, eu não... eu não sou um cara da escrita, entendeu? Eu prefiro pensar, é falar.... tipo cantar é sabe assim, dizer... e alguma pessoa... é por isso, é... a minha pequena grande mulher ela me deu esse rádio porque eu prefiro falar assim, manja? E aí eu não tenho muita pra pensar, se eu pensar eu não escrevo, então eu prefiro falar entendeu? [Você fala pro gravador e...] É e aí ele grava, ou senão sei lá, arrumar uma pessoa bacana que escreva seria legal. [...] Eu escrevo, escrevo bastante coisa, tenho muita coisa já escrita, inclusive essa se., nossa inclusive esses dias tá a milhão minha cabeça! [A cabeça tá a milhão?] Tá muito legal, assim! [Tá dando tempo de anotar, de falar no rádio?] Eu tô falando cara! Mas eu tô ficando quieto que eu tô aprendendo que o negócio é calar a boca! [É que quando você está falando pro rádio você está falando pra você mesmo, não é pra outra pessoa ouvir, né?] Â... não sei....

$[\ldots]$

$\tilde{A}$.... se eu pegasse essa fit... a fita da minha vida, apagaria várias partes de coisas que eu fiz assim que foi merda assim que tá aí pra gente aprender, né?

$$
\text { [...] }
$$

Também.... acho que é tudo na hora, tudo ali, você vai saber, até coisa que eu não gostei e fiz, depois ...na hora que eu fiz, eu falei puta que merda! Que merda! Que merda! mas aí você vai e as coisas estão indo e... é uma fita, né malandro? O que foi gravado já foi gravado (risos) não dá pra voltar (risos) entendeu?

\subsection{A história de Lucas}

Lucas deixa explícito em sua fala a importância da presença de outro ser humano que confiasse nele. A partir daí ele conseguiu buscar outras formas de estar no mundo. 
eu fui conseguindo várias outras coisas, entendeu? Consegui comprar minha casa agora mesmo passando dificuldades agora mesmo, porque todo mundo precisa de um trabalho... então eu tô feliz entendeu? Eu não me deixo levar... eu não... não me vejo mais nessa forma de precisar roubar pra mim ter as coisas, entendeu?

\section{É preciso viver, é preciso confiar em alguém, é preciso que alguém} confie em você.

...então não adianta a gente chegar e falar, a gente tem que deixar viver a vida... a vida, a vida a gente mesmo que aprende, não tem uma pessoa que vai chegar na gente e falar "ó sua vida vai ser isso, isso e isso, segue por esse caminho que vai dar certo" a gente mesmo que tem que seguir um caminho....ai que que acontece? Nesses fato de mudança... a gente tem que procurar aquelas pessoas que, sabe? Acreditam em você, acreditam que você pode conseguir trabalho, acreditam que você pode.... te ajudar num trabalho, pode te ajudar na sua vida, então é... a gente tem que correr atrás dessas pessoas, porque, na porta de casa todo dia bate lá... "ô vamos fazer uma fita, trabalha aqui numa boca, ou faz isso e aquilo..." entendeu?

\section{$O$ apoio de um amigo}

....tipo eu tinha um amigo lá, um amigo e a mãe dele gostavam de mim muito, então ele era um amigo tipo irmão, entendeu? Lá no bairro... e aí a mãe dele ligou lá pra semiliberdade e falou "ó, pode deixar ele vim passar o final de semana na minha casa, né?" Aí tá, eu ia todo final de semana passar na casa dela lá... Aí nisso que eu fui passando o final de semana lá na casa dela, eu fui, tipo, meu vô foi vendo que eu estava mudado, entendeu?

\section{O Coordenador do Novolhar}

[No seu caso, você correu atrás de outras coisas, né? O que você acha que aconteceu na sua vida que ... você estava contando... quando você voltou pra casa do seu avô, você estava lá, parecia que estava tudo bem, mas na sua cabeça estava que você queria continuar naquela vida, né?]É, então...daí foi essas oportunidades, entendeu? Foi as oportunidades que foram surgindo, pra mim não ter esses pensamento, entendeu? Quem me ajudou muito foi o Paulo Santiago que... que me deu a maior força mesmo, que estava comigo ali lado a lado, ele conversava comigo, me chamava pra mim não ficar pensando besteira, confiava em mim, deixava os equipamentos, deixava eu levar os equipamentos pra casa, entendeu? Então ele foi a minha.... a minha esperança de vida, entendeu? Ele foi a minha... como é que se diz? A minha confiança, entendeu? A minha confiança porque é muito difícil você... é... ter passado pela Febem é... o povo sabe que você rouba, sabe que você faz aquilo... e dá uma coisa na sua mão de... 4 mil, 5 mil.. deixar com você assim ainda de você levar pra casa, entendeu? Então ali foi na onde que eu 
vi que estava tendo confiança em mim... a minha vó começou a me ajudar também, meus tios iam lá conversar comigo, aí foi na onde que eu fui... perdendo... perdendo essa trauma de ficar ... ah quero roubar, quero aquilo, quero ter meu dinheiro aí, tipo... começar conseguir minhas coisas, começar consegui...

(...)

Quando eu tô com dificuldade em casa, tá faltando isso, tá faltando aquilo, então eu chego no Paulo e falo: pô P. tá faltando isso, tá difícil.... o P. sempre me dá uma força, entendeu? Tipo... ele não abaixa o meu astral, ele "você vai conseguir...isso e aquilo, continua tentando" então eu sempre tô procurando, sempre tô, assim, procurando algum trabalho pra mim não abaixar a cabeça e não pensar negativo, né?

O jovem falou do encontro de dois seres humanos, de alguém que o resgatou da condição de humilhação social.

Só os homens elevam os homens à dignidade humana, só os homens excluem os homens da dignidade humana. Efeito da desigualdade política, o humilhado social é um fato psicossocial que reconduz sempre o homem ao outro homem. Seus determinantes mais variados, sua generalizadora cristalização nos fatos de reificação, não deviam iludir-nos sua indeterminação de base: a desigualdade não pode nunca dispensar os homens para que se mantenha. Não poderá igualmente dispensá-los para que seja neutralizado e cancelado. (GONÇALVES FILHO. 1995. p. 154)

\section{O Avô}

... meu vô e теu vô viu que eu estava fazendo coisas diferente, que não estava com aquele mesmo pensamento, entendeu? Aí ele falou "ó, vem passar o final de semana aqui em casa".

A confiança dos outros promoveu em Lucas a possibilidade de aprendizagem de algo novo. Ele passou a confiar em si como alguém que é capaz de fazer, de saber. Ocupou o espaço da potência em si mesmo. Após a realização do curso de vídeo e produção ele conseguiu algumas oportunidades de trabalho.

\section{As possibilidades de trabalho}

...aí esse Câmera aí que estava comigo lá, ele ganhou a liberdade dele, ele morava em Bauru, ele teve que ir embora, aí só estava eu e o Paulo, o Paulo pegou e falou "e agora, o que a gente vai fazer?" eu falei, não, eu sei gravar... sei gravar e foi nessa que eu passei em todas as Febens, gravei, e o Chalita assistiu tudo, todo mundo gostou, aí o Paulo começou a me chamar pra fazer outros trabalhos, aí comecei a ser câmera do Novolhar... , aí nisso, 
teve uns outros adolescentes que veio fazer curso... tudo, começaram a fazer cursos, eu ajudava eles, tudo e sempre fazendo freela pra Novolhar, fui fazendo aí, tipo eu falei, não, vou correr atrás por mim mesmo, aí eu comecei a correr atrás... fui trabalhar pro Padre Antonelo, aqui embaixo, perto do Parque D. Pedro, ali, comecei a fazer o programa do Padre Antonelo... [Gravando também?] Gravando também, aí tipo eu... eu peguei fui... fui fazer um trabalho pra TV Futura, pro Gilberto Dimenstein, aí lá.... na onde que eu fui fazer esse trabalho, eu não fazia nem câmera, nem assistente de câmera, eu fazia assistente de produção e tipo... eu achava que era bom, né? Porque televisão você tem que aprender tudo, desde a câmera até produção pra saber tudo que acontece, né? Ter uma noção de tudo. Aí eu peguei, fiquei trabalhando com ele durante 3 meses, com o Raí e o Gilberto Dimenstein e os outros pessoal, aí eu peguei e fiquei desempregado, né? Porque eles fizeram contrato comigo de 3 meses, aí eu voltei pro Novolhar, comecei a fazer os freela na Novolhar, aí teve um... a Novolhar teve um... teve um projeto que..., não conseguiu o projeto não, a Novolhar tem... tem um programa com a TV PUC e reuniu vários jovens pra, pra fazer esse programa e eu estava invisivel também, tava eu, o Rafael e mais um fazendo câmera pra esse programa, aí tipo... passou um mês, 2 meses, aí eu peguei, como que eu tinha meus contatos, o... volta, posso voltar? [Pode, claro...]

\section{A Emissora de TV}

É... quando eu estava na semiliberdade que... que eu comecei a fazer o projeto da... o...o curso da Novolhar, teve um pessoal da TV que foi lá, foi lá gravar, gravar o projeto da Novolhar, tudo, aí eles se interessaram, se interessaram na minha vida e foram conversar lá com a minha família, né? E nisso meu vô falou, falou na... pra eles mesmos que não me aceitava de volta e isso e aquilo... Como é que eu tô? Eu tô tipo, indo pra frente.... Aí que o meu vô falou que não me aceitava isso e aquilo e eu conheci os pessoal da... da $C$., tudo e eu fiquei, ficou como um contato, mas nunca esperava nada, aí eles me chamaram um dia pra eu ir lá visitar, eu fui lá, visitei, conheci a C., tudo e nisso, só ficou por isso e mais nada, aí tipo eu conheci a Neide e a Ana Lu lá da TV C., de quando elas trabalhavam lá, que hoje elas estão na G., aí eu peguei e tipo, comecei a fazer os trabalhos pra Novolhar, tudo e....

... é fui fazer trabalho pro Padre Antonelo, fui fazer trabalho pra TV Futura, aí eu voltei, tinha voltado pra Novolhar, pros cursos da Novolhar aí eu peguei fui fazer o programa lá da TV PUC, e passou dois meses... eu peguei e falei, não, eu preciso ver alguma coisa mais... sabe, eu quero televisão mesmo, eu quero ver qual que é, e tipo, eu tinha o telefone da Ana Lu e da Neide Duarte, aí eu do nada, lá em casa, fuçando nas minhas coisas achei o telefone delas, vou ligar... nisso que eu liguei, tinha uma vaga lá de boy de jornalismo, aí tipo, mas sabe, eu não estava tão interessado assim, é... eu queria câmera mesmo, aí eu conversei com o Paulo, conversei com o pessoal que estava aqui, e nisso o Paulo não queria que eu fosse, o Paulo queria que eu continuasse na Novolhar, mas aí eu pensei assim, né? É registrado, uma coisa pra mim pro futuro, né? Aí eu peguei, fiz um, tinha gente que não queria que eu saísse da Novolhar, peguei e falei, não, eu vou só pra mim ver como que é, aí a mulher, a Carol, a mulher da TV C. que trabalha lá no... $R H$, pegou e falou "faz um teste uma semana, fica aqui uma 
semana, se você gostar, você continua, a gente te registra, se você não gostar, tudo bem", aí tá, eu fiquei uma semana lá e gostei... eu comecei a fazer lá, eu fui pra lá, comecei a trabalhar de boy de jornalismo, nisso eu fui conhecendo muita gente, sabe?

(...)

.... ela pegou e perguntou pra essa secretária e falou se ela confiava no nosso trabalho, né? Ela falou "ó, você confia nos boy, não sei que” ela pegou e falou "não, não confio em nenhum boy"... tipo e.. na onde que ficou minha cara?, entendeu? Pô meu, ela trabalha com a gente... ela dava dinheiro, ela dava cheque pra gente buscar dinheiro no banco, valor que.... a gente nunca tinha visto na vida, entendeu? Tipo 25 mil, 30 mil, a gente ia no banco, pegava, levava lá, fazia tudo certinho, fazia todo o trabalho certinho, todo mundo gostava da gente, não tinha o que falar, entendeu?

O adolescente pede ao adulto uma orientação para sua vida, pede limite para os seus atos. Pede também respeito e confiança. A necessidade de orientação relatada por quem não recebeu orientação dos pais quando criança. A ambigüidade na fala, pois afirma que mesmo com orientação, a pessoa precisa aprender por si mesma.

\section{Ser pai é orientar}

[Como você pensa uma relação com um filho seu? Como seria o L. pai?] Ah.... seria totalmente mais rígido, né? Mais... seria... porque eu não ia querer deixar ele passar pelo que eu passei, eu queria dar mais (...) aí... tipo... eu não deixaria ele ver o mundo do jeito que é.... sei lá, botaria ele na escola... mostraria pra ele o que é bom, o que não é bom... porque... se você tem uma pessoa que te mostre ali... o... o dia-a-dia mesmo, o que é a periferia, a periferia é assim, né? [...] Então eu mostraria pra ele qual que é o mundo, dentro da própria comunidade, dentro da periferia, como a gente fala, e mostraria pra ele o mundo fora disso, como se diz? Oportunidades, entendeu? Tipo ah, você quer ser jogador, ah você quer ser radialista, você quer ser isso e aquilo, você tem que estudar, tem que aprender, pra conseguir seu futuro mais pra frente, entendeu? [...] ...da parte do meu filho eu acho que, mesmo sendo menina ou menino, tinha que ter um... uma pessoa pra dar um exemplo, um exemplo de... está ali todo dia, não só o falar... um amigo chegar e é isso e aquilo, o tempo todo lá fora... você nunca vai ver se não tiver uma pessoa do seu lado te mostrando como que é o mundo... É assim, você aprende o dia-a-dia, você aprende o dia-a-dia, cada dia é um aprendizado, cada dia é uma escola pra você, um aprendizado diferente...

(...)

... então não adianta a gente chegar e falar, a gente tem que deixar viver a vida... a vida, a vida a gente mesmo que aprende, não tem uma pessoa que vai chegar na gente e falar "ó sua vida vai ser isso, isso e isso, segue por esse caminho que vai dar certo" a gente mesmo que tem que seguir um caminho..... 


\subsection{A história de Alex}

Alex relata a importância do encontro com outro humano no momento que fala do coordenador do Novolhar, quando fala da importância da família por perto e da falta que sentiu de seus irmão e pais quando estava internado na Febem. O medo de perder a mãe, a percepção dos amigos sinceros, a possibilidade de um trabalho em que era respeitado foram condições para a conquista de uma nova forma de estar no mundo.

\section{O início da mudança}

Eu não quis fugir porque eu queria cumprir, cumprir pra ver se eu melhorava, eu já tava pensando em melhorar porque aquilo já não... já não tava me agradando, assim, mas mesmo assim, na convivência com os caras eu era de um jeito só que com o pensamento de outro, assim, eu era de um jeito que era aquele cara marrudão, meio bravo, mente psicopata, assim (rsss) pra que.... a convivência fosse melhor com, com os outros, assim...mas minha consc... mas meus pensamentos não falava pra ninguém, mas era de melhoria. Eu acho que todos têm esse pensamento de melhorar quando sair, mas nunca conseguem... dificilmente....

\section{A importância da Família e o medo de perder a mãe}

ah e fora que eu passei aniversário, passei natal, passei o ano novo, carnaval, todas as festividades, dias das mães, dias dos pais, isso era sempre o que me chocava assim, que era, como a gente dizia lá dentro, que era o que pesava a cadeia, era o que pesava a mente assim, que era esses dias de festividade que você não podia estar com a família, mas tinha os momentos bons que eram os dias de confraternização, os melhores momentos era o que era, o que tava com a família sempre junto, acho que isso eu vou ter na minha mente também e não quis isso mais pra mim, quando eu saí eu... fora que minha mãe teve.. eu falei que no $5^{\circ} \mathrm{DP}$ ela ficou internada num... então, ela ficou internada no Hospital do Câncer depois, ela ficou internada 2 vezes, na primeira vez e na segunda vez ela ficou internada no Hospital do Câncer, é... com o mesmo problema que era de AVC... minha mãe teve dois AVCs e no decorrer da minha... da minha tirada de cadeia que era... no meu tempo na Febem ela teve AVC, teve também por causa da rebelião que mostrava o negócio, tal e aí ela teve esse AVC de novo, aí eu criei na minha conscientização que eu já tava matando minha mãe aos poucos, meu e isso pra mim já estava me corroendo e que se eu perdesse minha mãe era a única coisa que eu tinha na vida, porque meu pai não... não me deu tanta atenção assim quanto minha mãe, na base só me criticava, não me deu tanta atenção assim como minha mãe, então... a minha mãe era a única pessoa que eu podia contar nessa, naquele momento, fora minha irmã e meu irmão, né? Mas se eu perdesse minha mãe eu ia me sentir culpado até ... até o final da minha vida.. porque era a pessoa que 
estava ali junto comigo e eu estava matando aos poucos, sem.... mérito nenhum, sem.... escrúpulo nenhum, vamos dizer assim... $E$ aí isso foi martelando minha mente e... eu acho que foi o que ajudou também eu a ... a mudar de vida...

[...]

Nossa, minha mãe agora, ela tá super feliz, ela tem uns problemas de pressão, tal, mas eu cuido super bem dela e minha mãe (rss) minha mãe é maravilhosa! Minha mãe é super boa, assim, e agora está ... (...) mas a convivência com a minha mãe está super bem, super boa, assim, ela está super feliz, super feliz, ela fala de mim, assim, pra qualquer pessoa com muito orgulho de..., mas ela não fala que eu já passei pela Febem, essas coisas, mas ela fala com muito orgulho que.. que é eu que cuido dela porque meus irmão estão casados... (...) é isso, minha vida, minha vida continua, minha vida está mil, minha vida está 100\%, 1000 maravilhas... Eu acho que meu sonho, meu sonho já está realizado, que é vê minha mãe assim com um sorriso assim, por mais que ela esteja um pouco doente, algumas coisas, ela está até afastada do serviço, mas eu tô feliz porque ela está com um sorriso melhor, uma feição melhor e sabe que... minha convivência é outra, meus amigos são outros...

Durante o período que realizei trabalhos com adolescentes que cometeram atos infracionais, o apego à figura da mãe foi sempre muito forte. Ela aparece como a única pessoa em quem eles podiam confiar no mundo. Quando o adolescente perdia o medo de que sua mãe sofresse com suas atitudes, isso podia significar uma estruturação muito grande no crime.

Roman (2007. p.26) fala do papel essencial da família e em especial da mãe para restituir o valor ao ser.

\section{As amizades sinceras da infância}

... a amizade mais sincera, que eram... eram com as pessoas que cresceram junto comigo, aqueles que... os primeiros... que até hoje assim, a gente troca telefone, tem um contato, e são as pessoas que não entraram no crime junto comigo, mas eles sabem da minha vida e mesmo assim não foram ... pode não.. é... abandonado entre aspas, é.. eu digo assim, por exemplo no dia é.. quando eu tava preso eles mandavam um abraço e tal, mas o que eu queria era ... era por exemplo, um pacote de bolacha, mas eu sei que não era eles que tinham que tá ali comigo, chegando junto comigo e com a minha família, disso eu sei, então mas é... essas são as amizades mais verdadeiras que eu digo hoje que é, são meus amigos, que eram as pessoas que ia.. que foram criados junto comigo, que são até hoje, até hoje uns faz faculdade, uns são ... trabalham, uns já tão casados, estudam, ou faz qualquer coisa, mas não entraram no crime junto comigo e .... assim.... eles têm uma mente diferente, que a conversa é diferente, você dá risada, sem ter a mente maléfica de.... de qualquer coisa já ter maldade, já querer atirar, já querer 
matar, já querer assaltar, se falta dinheiro já assalta, não, os caras mesmo estando desempregados os caras tem a vida deles e convive com isso muito bem, que por mais que estejam passando por um processo de problemas, é... eles sabem como se, como lidar isso, lidar com essa situação, acho que essas são, acho não, tenho certeza que são as amizades verdadeiras que estão, que duram e que estão durando e... devem durar pra sempre, assim....

\section{O curso no Novolhar - outros caminhos são possíveis, a importância de receber orientações}

...e aí surge a Novolhar, a Novolhar foi, tem.. foi a ONG que... que me direcionou quando eu saí... o Paulo Santiago, ele me ligou, que é o... acho que é o coordenador da Novolhar, coordenador da Novolhar até hoje e aí ele me ligou e falando, e eu já tinha feito o curso lá em Franco da Rocha, já tinha terminado, já tinha ganhado até diploma lá, tenho até a foto.... [...] foi, foi super legal, eu gostei do curso... e aí quando eu saí, eu já queria parar assim, mas... eu não tinha uma direção assim... eu não sabia por onde começar... e eu acho que foi a Novolhar que me deu a direção, assim, de um curso, de saber que tem... tem caminhos, de saber que tem oportunidades também... que não é só... é.... tipo....que não era só aquela vida que eu tava vendo que existia, tinha outras à minha volta, tinha outros mundos, tinha outros, outras, outras convivências... e aí ele me chamou pra saber se eu queria fazer, se eu queria continuar o curso, né? E aí fiz, acho que eu fiz uns 2 anos de curso (rss), cada 6 meses eu me... eu concluía o curso e já fazia outro e já fazia outro, acho que isso foi uns 2, 3 anos, não, acho que uns 2 anos só fazendo curso, acho que eu fiz uns 4 cursos de... de vídeo produção, devo ter um monte de certificado, mas esse era legal, era legal porque tinha... tinha as pessoas que estavam dentro da Novolhar, que davam essa esperança de... de um mundo... de um mundo bom, diferente do que era....

\section{Os trabalhos que trouxeram humanidade ao jovem que começava um novo caminho}

Bom e aí eu consegui um estágio que era no.... através da Novolhar eu consegui um estágio que era na... no Museu da Pessoa, no Museu da Pessoa, trabalhei por 1 ano e 2 meses, como estagiário, só que remunerado, né? Ganhava, meio período, eu ganhava e ... era na área de vídeo, assim, de assistente de cenografia embora já... já tava operando câmera, bom e aí eu saí do Museu da Pessoa, saí depois que acabou o estágio, eles me seguraram mais um tempo, mas acabou o.... é......аcabou os... caramba esqueci... os contratos com a Petrobrás... acabou a grana.... que era o que sustentava o Museu da Pessoa, que era onde entrava o dinheiro e aí as pessoas foram embora, inclusive eu... os funcionários, vários funcionários na verdade, o Museu da Pessoa era grande pra caramba em termos de funcionários, bom e aí eu, através da Novolhar também eu dei uma entrevista que foi para o programa Filhos na STV, na... Rede Sesc Senac de Televisão e aí eu acho que contei praticamente, eu contei essa história mais ou menos e aí eles me deram uma bolsa com o equivalente, acho que era de 3000 reais, do curso de operador de câmera... [Você foi fazer?] Eu.... eu fiz 
a prova, só que eu não passei e aí o que que eles fizeram? Como eu não passei, eles me deram outra bolsa, que era de Oficina de Vídeo. Eu fiz o Oficina de Vídeo, prestei a prova de novo, passei, aí a única coisa que eu paguei, foi 20 reais que era da...da inscrição e pra você fazer o teste, né? Da prova... passei no teste e aí eu fiz o Operador de Câmera... Fiz o Operador de Câmera, mas assim... ainda não peguei o certificado ainda, já faz acho que 1 ano que eu terminei, 1 ano não, minto, acho que até mais... já tô na... na TV PUC já há 1 ano e 4 meses, mais ou menos, que foi em fevereiro que eu entrei... [...] Então eu tô 1 ano e...1 ano e meio, praticamente, mais ou menos ou até mais. Bom e aí eu fiz o Operador de Câmera, mas eu não dei entrada na DRT, no DRT, que é Diretoria Regional do Trabalho, e aí eu fiz um freela, tava na... na....eu tava fazendo o curso e algumas... eu tava na... fazendo alguns projetos com a Novolhar de gravação.... e aí eu até recebi um salário... e aí eu fiz um freela pra TV PUC, de operador de câmera, os caras gostaram do meu trabalho e aí depois de uns 2 meses, assim, que eu já tinha feito o freela, eles me chamaram pra... pra...pra poder ter um contrato de ... de trabalhar com eles, é...não fixo com registro, assim, que ainda hoje eu não tenho registro, mas futuramente, provavelmente vamos, vou ter o registro, ainda bem, né? Tava demorando rsss...

\subsection{A história de Douglas}

Quando foi entrevistado, Douglas ainda cumpria pena no sistema prisional. Na realidade, naquele momento aguardava o resultado do seu pedido de recurso. Poderia ir para o sistema fechado, continuar no semi-aberto ou sair por condicional.

Este jovem relata a importância de ter uma crença para sair da vida do crime. Fala também da necessidade do apoio da família e dos professores. Relata ter sentido pouco apoio da família e da escola em sua trajetória pessoal. A possibilidade de ter fonte de renda também foi levantada por ele como importante para não continuar na criminalidade.

\section{A necessidade de diálogo}

hoje em dia o que falta é muitos pais sentar com seus filhos e conversar... existe droga, é assim, assim, assim, existe sexo, só que você tem que usar camisinha, tem que fazer assim... então....(...)Falta conversa entre os pais, hoje em dia tem mais pessoas é.... assim... que não é da família, pessoas assim que dão uma explicação pra nós, que nós precisava ouvir do que, dos nossos pais, das nossas mães, que mulher você recebe mais é... da tua.... conversam mais com a mãe, né? 
Agora o filho não, você tem que sentar, você tem que explicar, o meio da marginalidade é aquilo, só tem dois fundamentos, cadeia ou cemitério, "ó eu fui preso, passei por isso, isso, isso, dentro da cadeia, você quer isso pra você? Não quer, então vamos estudar pra ser o que eu não fui", sempre você influenciando a vida da pessoa. Mostrar o que é a vida. [Se alguém tivesse feito isso com você?] É... talvez eu não teria.... acontecido tudo o que aconteceu comigo hoje em dia...

[...]

Tem que ter muito diálogo.... hoje em dia também os professores.... hoje em dia, que falta mais o diálogo, carinho do professor, porque hoje tem muitos professor que tá na escola, dá aula tudo, mas não tem aquele carinho, "há, não vou dar aulas pra estes pestes aí tudo, daí já sei que no final do mês eu tenho o meu e já era!’ Tem que ter mais carinho, amizade, você vê que aquela criança está tendo problema dentro de casa, né? Que você percebe, então você tentar adquirir aquela criança pra você, ela sempre está ali, não, se sentir querida, pelo menos por alguém, dai é isso.....

[Que não seja pai e mãe, mas como no seu caso, você como tio está tentando fazer....] Isso... isso... tô explicando, tudo, pra que se um dia se querer aprontar, fazer alguma coisa assim, você já sabe que você incentivou, você deu o passo pra ela seguir o caminho bom, né? Que não foi por falta de palavra ou falta de diálogo, porque quis mesmo, né?

\section{A família por perto}

o fato também da primeira vez minha mãe teve uns problemas tudo, da primeira vez minha mãe teve um aneurisma cerebral, né? Um derrame... nervoso, né? Porque.... eu preso e ela com problema no serviço.... problemas com meu padrasto é.... ajuntou com emoção boa que foi o casamento do meu irmão, ajuntou tudo isso, aí ela teve um AVC, né? Aí eu estava preso ainda na Colônia de Franco da Rocha, então daí por causa disso, por causa da minha mulher, a família da minha sogra, minha sogra, meu sogro, que até um tempo não gostava de mim e agora tão vendo que eu estou mudando, até chamei meu sogro também pra trabalhar comigo, que arrumei serviço pro meu sogro, então viu que eu estou querendo um objetivo mesmo теи...

\section{Deus para tentativa de sair da vida do crime - como se a vida não estivesse em suas mãos}

Aí nós teve que sair fugido daqui... aí quando nós voltamos, nós falamos "não, não quero mais saber, rezamos, pedimos tanto pra Deus pra não entrar nessa vida, não adiantou, agora nós vamos entrar de cabeça, daí começamos a roubar, compramos arma, roubamos, compramos arma, fazendo festa toda semana, e assim foi indo... 


\title{
A ajuda de um companheiro e a importância de ter uma fonte de renda
}

\begin{abstract}
Atualmente eu consigo porque eu conheci um rapaz que estava preso comigo, né? Que ele tem uma concessionária de carro e uma funilaria, ao qual ele estava tirando o carro... colocaram um carro batido dentro da funilaria dele pra ele arrumar e quando ele estava colocando o carro pra fora, as polícia veio, abordaram ele falando que o carro era roubado, daí levaram ele preso como 180, daí saiu, ele foi lá, que chamam de apelido, né? Daí ele me chamou, "ô J. quando você sair daqui, eu quero, não quero ver você roubando, você aprontando mais, você vai trabalhar comigo". E graças a Deus, Deus colocou ele no meu caminho pra estar ajudando.... Eu trabalho direto com ele, daí... trabalho de sexta-feira num baile que ele dá, na Celso Garcia, que é um baile da Nostalgia, pra terceira idade, que eu trabalho como copeiro e bar man e.... casei, hoje tenho minha filha, tudo... voltei com a minha mulher, minha mulher que tem uma filha com ela, então hoje em dia a minha vida é essa, eu trabalho, tô agitando, esperando ajeitar esses negócio pra mim voltar a estudar...

[...]

Porque graças a Deus quem tá me dando uma oportunidade é esse rapaz aí que eu trabalho no baile, certo que é pouco, mas é um dinheiro que ajuda, às vezes eu chego... pra mim não precisar roubar nem nada, eu chego e chamo ele de tio.... é... tio P. o nome dele, tio P., eu chego e falo, "o mano, tem como você me emprestar 30 reais pra eu comprar um gás em casa?" ele vem, puxa "o dinheiro tá aqui", aí chega no dia de pagar, você vai pagar ele fala "não quero o dinheiro não, eu te dei" ele tá ali pra ajudar mesmo... então hoje em dia eu dou graças a Deus que Deus colocou ele no meu caminho, ele, a tia Elaine, que eu pego parafuso com ela pra fazer também, então são pessoas que estão ali na procura de ajudar, minha sogra também me ajuda bastante... então hoje em dia eu converso com meus irmãos, tudo, mas se eu converso no particular o dele, ele pro lado dele, eu pro meu lado, cada um com a sua liberdade, cada um separadamente...
\end{abstract}

\section{A extrema violência assusta e pode afastar da criminalidade}

Douglas relata em sua entrevista algumas passagens de extrema violência vividas dentro da cadeia. A violência, como foi visto em capítulo anterior, impede a formação do humano no homem. Ela gera mais violência como resposta possível (as rebeliões que reivindicam direitos) e, no caso desse jovem, levou-o a questionar sua forma de estar no mundo.

Agora, também... o que eu tenho a dizer assim, que a minha vida, eu passei essas coisas tudo essa vez que eu fiquei abismado, coisas que eu nunca tinha visto da primeira vez eu vi dessa vez, né? [...]Uma também foi depois dessa Mega de 2006.... eu vi coisa que foi terrível.... é os Faxina com pano na cara, com faca que nós mesmos teve... que nós mesmo amolamos pra poder grudar os funcionários é.... Muralha atirando de (...) de fuzil pra cima de nós, amigos nosso perdeu metade de mão, perdeu dedo, tomou tiro, é... ficou 
por lá na enfermaria porque não saíram de dentro, não foram pra hospital nem nada, só sai se você estiver realmente morto...

\title{
A importância de espaços de cultura e lazer para a juventude
}

Nesses espaços de cultura e lazer foi possível encontrar pessoas que confiaram nele e que apostaram na sua capacidade de mudança. A confiança como importante veículo de transformação.

\begin{abstract}
Me arrependo muito, agradeço as pessoas que me ajudaram bastante: a tia Elaine, a tia Fabiana que era monitora também, a qual aprendi a fazer teatro, essas coisas toda, só que hoje em dia falta oportunidades pros jovens da.... vamos se dizer, da Cohab, né? (...) agora você num centro comunitário, pro jovem, trabalhando pro jovem, o que acontece? Ali eles estão desenvolvendo coisas pra própria mente, como a própria... não sou crente, nem evangélico... eu acredito naquilo que eu vejo, né? Não sou de religião nenhuma, sou eclético, né? Então eu acredito só em Deus e pronto, mas uma palavra que está escrito na bíblia que eu gostei e acredito que é.... "mente vazia, oficina do diabo", então ocupar a mente da... juventude, então esse é o meio de muitos jovens não entrar no meio do crime, de você tirar, em vez de jogar os jovens no meio da sarjeta, no meio do... da marginalidade, você está tirando.....
\end{abstract}

A constituição de um indivíduo se dá no cruzamento de uma rede. Uma rede invisível e tridimensional. Há fios da história do universo, fios da história das sociedades ocidentais, outros fios que trazem a história pessoal e caminham para um projeto de futuro, o futuro da humanidade, a volta ao passado. Os fios enrolam e se soltam, aproximam e se afastam, sobrepõe-se.... Caminhamos por e com essa rede e vamos construindo uma existência individual, singularidades que enriquecem o meio comum.

Nas entrevistas, toda vez que a pergunta era o que leva um adolescente a cometer infrações, ou a deixar de cometê-las, as respostas tendiam ou só ao indivíduo ou só a sociedade, sem perceber que o indivíduo é um encontro de universais e que deve haver, necessariamente, tensão entre indivíduo e sociedade.

Os adolescentes pedem e necessitam para a constituição de sua identidade: respeito, confiança, cuidado. Necessitam de uma figura de 
autoridade para que possam se espelhar. A indústria cultural oferece rostos sem história, corpos modelados artificialmente. Está impedindo, assim, o desenvolvimento do indivíduo.

A identificação de um humano com outro foi possível na trajetória desses jovens. Está aí a oportunidade de transformação dos adolescentes que cometem atos infracionais em cidadãos que podem construir a possibilidade de transformação social. 
Capítulo 12 - CONSIDERAÇÕES FINAIS A COSTURA POSSÍVEL 


\section{CONSIDERAÇÕES FINAIS - A COSTURA POSSÍVEL}

Essa pesquisa partiu dos pressupostos da teoria crítica tal qual apresentado por Guba (1990).

Para a teoria crítica há, ontologicamente, a existência de uma realidade externa ao homem que não pode ser totalmente percebida por ele. A natureza não pode ser vista como ela realmente é, só pode ser percebida por intermédio de um "filtro de valores", ou seja, os valores dos pesquisadores estão presentes na escolha do objeto de pesquisa, nos instrumentos e modo de análise, na escolha da teoria e de suas interpretações. As idéias do pesquisador fazem parte do processo de pesquisa e conhecimento e esse importante e fundamental aspecto compõe seus resultados.

Toda pesquisa é um ato político e deve estar comprometida com a transformação da sociedade e a emancipação dos indivíduos. Deve também assumir questionamentos sobre seus próprios fundamentos. Por essa maneira de se fazer ciência, os valores dos pesquisadores interferem na pesquisa e estes devem se aproximar do objeto de forma clara e objetiva. Metodologicamente, elimina-se a "falsa consciência" para promover a transformação. Portanto, a explicitação de conceitos e idéias é uma das características da teoria crítica.

Segundo Guba (1990) deve ocorrer um questionamento de verdades externas ao sujeito, que no caso dessa pesquisa, ocorreu no questionamento de condições sociais tidas como "verdadeiras e inquestionáveis".

Para se fazer isso, foram levadas em consideração as crenças e valores dos sujeitos envolvidos, foram explicitados os modos de pensar, entender e questionar o mundo. A metodologia, a ação conseqüentemente, pretendeu buscar a autonomia e emancipação dos sujeitos e a transformação da sociedade.

As etapas da pesquisa foram apresentadas ao leitor com o intuito de que esse tomasse conhecimento do processo como um todo. Cada um dos capítulos pretendeu ser importante para compor a discussão proposta por esse trabalho. 
Tenho certeza de que os aspectos que compõe o fenômeno da prática infracional de adolescentes se entrecruzam, assim como os capítulos dessa dissertação.

As Considerações Finais é a parte da pesquisa em que o pesquisador deve amarrar as análises apresentadas na dissertação. A finalização apresentada aqui foi a maneira encontrada após esses três anos de estudo. Nesse sentido, as idéias receberam uma costura possível.

As falas de Alex, Breno, Douglas e Lucas foram ouvidas por mim com a máxima atenção. Espero ter conseguido dar a importância devida às histórias contadas por eles. Os jovens puderam ser conhecidos, suas vidas foram mostradas como formas de vida da juventude moradora das periferias das grandes cidades brasileiras. Como eles, há muitos outros nas mesmas condições.

Suas histórias enriqueceram a minha trajetória profissional e, tenho certeza, eles se tornaram visíveis para aqueles que leram esse trabalho. Não a visibilidade perversa dos que sobem nos telhados das Febem(s), ou a visibilidade virtual daqueles que são transformados pela mídia como contraexemplos que não devem ser seguidos, ou como cópias de um modelo estabelecido, mas a visibilidade concreta daquele que se mostra inteiro com sua história e assim enriquece a vida dos que cruzam o seu caminho.

A metodologia que se mostrou apropriada para responder às questões iniciais foi o Estudo de Caso. As conclusões de um estudo de caso devem ocorrer a partir da convergência das várias fontes de evidências utilizadas na compreensão da questão inicial.

Yin (2001. p. 121) define a necessidade da ocorrência de triangulação das fontes, ou de avaliadores diferentes, ou de perspectivas teóricas distintas ou de triangulação metodológica.

A triangulação e o encadeamento das evidências permitem perceber a validade da pesquisa que se utilizou do método do estudo de caso. Uma pesquisa cujo princípio é o da não causalidade dos fenômenos só pode se 
basear na análise dialética e não linear dos dados. Assim, pode-se afirmar que nesse trabalho foi utilizada a triangulação das várias fontes de evidências.

Um princípio importante para se definir a qualidade de um estudo de caso é que o leitor:

“[...]possa perceber que qualquer evidência proveniente de questões iniciais da pesquisa leve às conclusões finais [...] Além disso, o observador externo deve ser capaz de seguir as etapas em qualquer direção (das conclusões para as questões iniciais da pesquisa ou das questões para as conclusões). (YIN. 2001. p.127)

Esse trabalho teve a intenção de ir além das aparências sobre o assunto. Discutiu as condições que ajudaram no engendramento da produção do ato infracional por adolescentes, sem buscar explicações simplistas para o fenômeno. Buscou também conhecer esses jovens e ouvir deles quais as condições que os fizeram pararem de cometer infrações.

A análise sobre a história das leis brasileiras que regulam a vida de crianças e jovens, começando na época que o Brasil era colônia de Portugal, passando pela análise dos Códigos de Menores, do Estatuto da Criança e do Adolescente e do Sinase, teve a intenção de fundamentar a forma como a sociedade atual percebe a questão da infância e adolescência. Propostas antigas convivem ainda hoje com a nova legislação.

Contextualizar se faz necessário para poder entender práticas repressoras que ainda hoje são utilizadas nas instituições que lidam com adolescentes que cometeram atos infracionais. Conhecer o processo foi fundamental para poder entender as propostas de redução da maioridade penal como solução para a criminalidade juvenil.

Conhecer o processo histórico auxilia na compreensão do fenômeno, impede o velamento pelo véu da ideologia, promove a tomada de posição consciente por parte do pesquisador e dos leitores.

A análise sobre as mídias brasileira e latinoamericana quando o assunto eram as crianças e adolescentes foi fundamental para perceber como os meios de comunicação descontextualizam a notícia, apresentam visões parciais sobre a violência juvenil, não questionam os atores responsáveis por pensar soluções 
para os problemas, não apresentam políticas públicas pertinentes ou a falta delas.

Ao mesmo tempo a mídia divulga que os adolescentes pobres são perigosos, apontando-os como culpados em crimes violentos. Afirma que os adolescentes não são rigorosamente punidos pelo Estatuto da Criança e do Adolescente, mostrando um desconhecimento sobre essa lei. Mostra os jovens como autores de crimes violentos, sendo que na verdade eles são as maiores vítimas de homicídios no país.

Enfim, os meios de comunicação auxiliam na manutenção de uma forma de conhecer os fatos de maneira descontextualizada, impedindo o público leigo de construir uma opinião própria sobre o assunto.

O poder que a mídia possui na sociedade atual permite que ela reforce estereótipos, crie monstros sem história, apresente a violência como fenômeno individual e não como conseqüência de sistemas políticos e econômicos propagadores de violências. Os meios de comunicação cumprem o papel de manter as pessoas sem informação, ou com um conhecimento distorcido sobre os fenômenos sociais contemporâneos.

Através dos registros em arquivos foi possível conhecer o perfil dos adolescentes que cometeram ato infracional e cumpriram uma medida socioeducativa na Febem de São Paulo.

No geral, eram moradores da periferia da cidade grande, eles e seus pais apresentaram baixa escolaridade, estavam desempregados ou inseridos em trabalhos que remuneram pouco. Os sistemas de saúde, educação e transporte a que eles tinham acesso eram precários. Os espaços de cultura e lazer eram distantes de suas moradias, dificultando que estes jovens frequentassem tais centros.

As estatísticas sobre violência possibilitaram conhecer o fenômeno, contextualizando as crianças e adolescentes como principais vítimas de homicídios e outras violências. 
A importância da violência vivida pelos jovens entrevistados foi discutida após a leitura do conceito de humilhação social apresentado por Gonçalves Filho (1996). As entrevistas com os quatro jovens mostraram biografias no cruzamento com o social.

As violências sofridas por eles e as humilhações a que foram alvo foram explicitadas para a construção de uma visão correta dos acontecimentos: as crianças e adolescentes sofrem violências cotidianamente. Os adolescentes e jovens pobres são desrespeitados em seus direitos básicos por policiais, pelo sistema judiciários, pelas instituições responsáveis pelo oferecimento das medidas socioeducativas. As Febem(s) disseminam o terror que impede o reconhecimento do outro.

Quando um adolescente comete um ato infracional ele está devolvendo de forma violenta aquilo que sofreu na pele durante muito tempo - a violência do pertencimento ao grupo dos que não sabem, dos que não têm capital, da vida indigna dos que não conseguem sobreviver com o dinheiro ganho em trabalhos alienados, da falta de moradia, das humilhações sofridas - como indivíduo ou classe social - durante séculos.

Os exemplos advindos da minha experiência de trabalho com jovens moradores da periferia da grande São Paulo enriqueceram a discussão e mostraram outras histórias e muitas questões presentes na prática profissional. A familiaridade anterior com esse público, seu modo de ser, agir e falar, o conhecimento sobre os caminhos percorridos pelo adolescente que cometeu um ato infracional, desde que foi apreendido pela polícia, até o cumprimento de uma medida socioeducativa facilitou a minha aproximação e entendimento das histórias contadas pelos jovens entrevistados.

As experiências apresentadas por pesquisadores que trabalharam com adolescentes e jovens que cometeram atos infracionais: Assis (1999); Fefferman (2006); Roman (2007); Sales (2004); Trassi (2006); Vicentin (2005) e Vieira (2003) permitiram perceber a constância de certos acontecimentos violentos vivenciados pelos adolescentes em suas vidas e nas 
instituições responsáveis pelo acompanhamento da medida socioeducativa. Permitiram também mostrar a importância do assunto pesquisado e a presença dessa problemática nos grupos de pesquisadores das universidades brasileiras.

Tornou-se importante ficar atento para não transformar aspectos que compõem a entrada na criminalidade em causas da criminalidade juvenil. A pobreza, o envolvimento com o tráfico de drogas, a falência das instituições família e escola, a crise da autoridade no mundo moderno são antes sintomas e não causas.

A enorme desigualdade social entre ricos e pobres, a inexistência de políticas públicas adequadas para as crianças e adolescentes, o consumismo alimentado pela indústria cultural, o fetiche exercido pelas mercadorias e a não possibilidade de formação do humano nessa sociedade são responsáveis pela produção de uma sociabilidade e uma subjetividade que podem levar ao cometimento de infrações.

Com Martins (2003 a e b) e Roman $(2007)^{47}$ foi discutido que na sociedade ocidental o mais importante é o respeito à propriedade privada. Idéias sobre a atual divisão do trabalho, onde grande parte das pessoas executa um trabalho alienado que não promove a dignidade do trabalhador e o desconecta com a história da humanidade foram explicitadas. Os objetos produzidos para durarem são usados como se fossem descartáveis e passam a ser "consumidos" por aqueles que os detêm.

Com esses autores foi levantada a importância do conceito de fetiche da mercadoria. O valor que deveria ser atribuído a uma mercadoria é transferido para um sujeito, objetificando-o. As relações entre pessoas passam a ser relação entre coisas.

O fetichismo que essa mercadoria exerce sobre os adolescentes e, muitas vezes também adultos, o consumo exagerado que movimenta a máquina capitalista, a valorização daquele que pode ter objetos desejados para

\footnotetext{
${ }^{47}$ Apoiado na obra de Marx em O Capital: crítica da economia política. .São Paulo: Nova Cultural. 1988.
} 
se sentir e ser visto por outros como alguém poderoso está constituindo a base da socialização das pessoas.

$O$ poder de fetiche das mercadorias leva alguns jovens para a criminalidade. É como se esses objetos fossem preencher espaços de sentimento de desvalor e conferisse status ao sujeito. Para obter esses objetos, os jovens descumprem a primazia de respeito à propriedade privada, e o respeito ao outro. Chegam a desvalorizar sua própria vida em busca da satisfação prometida pela posse da "coisa". Nesse momento, com certeza, ele não tem consciência de que esses objetos não substituem as relações humanas. Eles estão em busca do sentimento de pertencimento a um grupo que partilha valores comuns.

Como foi visto ao longo desse trabalho, as condições apresentadas acima estão sendo responsáveis pela existência de relações entre as pessoas baseadas prioritariamente na interação entre negociantes. A convivência solidária foi substituída por um jogo de necessidades e interesses.

As condições reais, veladas pela ideologia impedem o pleno desenvolvimento de um indivíduo. Fazem com que as pessoas aprendam a ver questões complexas a partir da lógica de causa e efeito, como se fossem descontextualizadas e individualizadas. Mostram que as pessoas valem por aquilo que têm e não pelo que são ou podem vir a ser.

O conceito de indústria cultural discutido por Horkhaimer e Adorno (1985) foi utilizado para aprofundar as discussões de como condições sociais influenciam e sofrem influências de maneira dialética na vida dos indivíduos. A pseudo-educação oferecida pelas escolas não promovem o conhecimento das condições históricas de engendramento de fenômenos complexos. Ao contrário, ensina que as pessoas precisam ser empreendedoras, desenvolverem-se individualmente para tornarem-se lideranças e mantenedoras de sua existência individual. A lógica do individualismo é valorizada ao extremo. 
Os adolescentes são ensinados o tempo todo (pela escola, pelo mercado de trabalho, pela mídia de forma geral) que precisam ser como todos - esse ser genérico, sem fisionomia ou história, que tudo aceita, contribui e colabora.

Os modelos de identificação proporcionados pela indústria cultural são fragmentários, não possibilitam a identificação com uma figura de autoridade e a conseqüente formação de um indivíduo autônomo e crítico. Pode-se dizer que nessa sociedade não há indivíduos, há sujeitos buscando sua humanidade.

A necessidade imposta pelo consumo exagerado e pela massificação dos sujeitos impede a existência de seres singulares que possam conviver a partir dessas diferenças e com elas construir um espaço de aparição, onde a palavra e a ação de homens livres possam existir. Os adolescentes pobres estão impedidos de aparecer como seres plurais e únicos.

Com Arendt (1988 e 1997) foram discutidos aspectos da impossibilidade de plena formação do humano na sociedade atual, da crise na vivência da liberdade e autoridade, da necessidade de encontros com a singularidade de cada um para que se construa uma nova forma de estar no mundo.

A perda da valorização do passado e da história, onde as situações são apresentadas sem contexto, permite que a ideologia cumpra o papel de velar as condições do real. A perda da autoridade daquele que possui os conhecimentos acumulados ao longo da história da humanidade e da comunidade em que se vive promoveu a legitimação da violência como organizadora das relações desiguais entre os que detêm o capital e consequentemente o poder, e aqueles que detêm apenas a sua força de trabalho.

O reconhecimento de uma autoridade é necessário para o estabelecimento de relações assimétricas - entre adultos e crianças, donos do capital e donos da força de trabalho, mestre e aprendiz, médico e paciente etc. Mas para isso a violência não pode ser utilizada como substituto da autoridade. 
Nenhum tipo de violência se justifica. Nem a que pode ser exercida pelo uso da força física e explícita, nem tampouco a que pode ser exercida pelo uso das idéias.

A violência das idéias está garantindo que todos pensem de determinada maneira. Acreditar que o valor de alguém se mede a partir dos objetos que possui, pela casa que mora ou pela roupa que veste significa viver sob a ideologia necessária para manter o sistema capitalista de produção.

A violência está sendo usada na sociedade atual para manter um grande número de pessoas expropriadas de condições dignas de vida em prol de uma minoria que possui muito além do necessário para a existência de um indivíduo ou grupo.

O trabalho do homem deveria garantir sua sobrevivência e de sua família. O trabalho humano produz objetos que duram mais que a vida de quem os produziu. Esses objetos auxiliam os homens a conhecerem sua história. Eles dão sentidos a uma existência. Mas os objetos produzidos de maneira a serem rapidamente substituídos não conferem humanidade ao homem. A impressão passa a ser a de que tudo e todos podem ser substituídos a qualquer tempo.

Os objetos não duram, não contam sua história, foram produzidos de forma a exaurirem a energia de homens e famílias inteiras, seu valor não restitui a humanidade perdida em um processo de produção fragmentado e penoso.

Os homens sentem-se vazios ao produzirem uma ínfima parte de um objeto que, quando pronto jamais poderão consumir. Os homens estão impedidos de aparecerem, de serem livres, únicos entre tantos outros.

A liberdade é a ação de homens necessariamente diferentes que atualizam o passado no presente de cada ação. Mas na sociedade atual o mecanismo de poder exercido através da indústria cultural determina que todos devem ser cópias de um único modelo. Nessas condições não há alteridade e, consequentemente não há relação entre homens livres. 
A palavra e ação estão impedidas pela inexistência de espaços públicos onde a liberdade e a condição de alteridade de cada um possa aparecer. A ação revela o agente e refere-se a um contexto. Com a perda da história e a impossibilidade de existência do diferente o sujeito não se torna humano.

Os jovens pobres das periferias das grandes cidades estão impedidos de aparecerem como seres únicos. $\mathrm{O}$ ato infracional é um ato daquele que não está visível e que não pode aparecer. Seu ato o coloca em uma condição de visibilidade. Mas uma visibilidade perversa que não garante a existência de humanidade no homem.

O conceito de invisibilidade perversa e a visão distorcida construída pela mídia para acontecimentos geradores de violência, apresentados por Sales (2004) permitiram uma aproximação entre discussões sobre o fetiche da mercadoria e o impedimento da ação humana propostos pelos autores discutidos nessa pesquisa.

Condições sociais advindas do sistema capitalista de produção atravessam a existência individual de todos e promovem o sentimento de não pertencimento, de não existência.

$\mathrm{O}$ ato infracional de adolescentes é uma ação de um homem que está sofrendo, dialeticamente, influência de condições individuais e de determinações sociais, históricas e culturais.

Como foi visto ao longo desse trabalho o ato infracional ocorreu por condições engendradas na relação do indivíduo com o social. Ocorreram falhas e/ou faltas. A ruptura, ou seja, o ato infracional foi um pedido de socorro para que olhassem para ele.

Podem ser levantadas algumas condições que compõe um campo de forças que leva ao cometimento desse ato.

Os adolescentes sofreram influência da mídia e da poderosa indústria cultural que determina a forma como todos devem ser, agir e consumir. Eles estão inseridos nessa cultura de consumo a qualquer preço. Essa indústria 
promove a identificação com figuras vazias de história e transforma todos em cópia de um único modelo.

A violência vivenciada dentro de casa e na comunidade e que passa a ser banalizada pela freqüência com que foi presenciada, o fácil acesso a drogas e armas, o sentimento de desvalorização pessoal e tomada de posição frente às injustiças da vida, a condição econômica da família, as amizades, a presença de algum parente inserido na criminalidade, a inexistência de espaços de cultura e lazer onde homens diferentes possam conviver, criarem, serem livres para serem eles mesmos também são fatores que contribuem para a prática infracional.

A ausência de vínculo afetivo em relação à escola que não cumpre com seu papel de ensinar a todos os alunos os conhecimentos acumulados ao longo da história da humanidade e, como foi visto em capítulo oportuno, expulsa aquele que é diferente do que se é esperado; a impossibilidade de plena constituição da condição humana formam a teia que compõe o engendramento do fenômeno.

Com certeza relações familiares esgarçadas, com falta de diálogo e confiança entre os membros da família, com pouco controle sobre a vida do adolescente; a super proteção de um dos filhos em detrimento dos demais e falta de respeito pelo jovem foram condições que contribuíram para esse desfecho.

Como visto anteriormente, essas situações que aparentemente dizem respeito única e exclusivamente a vida de uma determinada família foram influenciadas por condições sociais de existência.

Para transformar a ação humana - enfatizando o público jovem por ser este o objeto dessa pesquisa - em ação entre homens livres é necessário criar espaços públicos para discussão de idéias e efetivação de planos que levem em consideração os sujeitos envolvidos no processo. A construção de novos caminhos depende dessa liberdade, que só ocorrerá quando as necessidades básicas da existência humana - moradia, alimentação, saúde, educação, lazer e 
cultura - não estiverem impedindo a possibilidade do encontro com outros homens livres.

$\mathrm{O}$ adolescente pobre que comete um ato infracional está impedido na sua condição humana de pluralidade, da existência do novo.

Arendt em Entre o Passado e o Futuro (1988. p. 194) relata:

[...] O estado de liberdade, porém, não se segura automaticamente no ato da liberação [das necessidades vitais]. A liberdade necessitava, além da mera liberação, da companhia de outros homens que estivessem no mesmo estado, e também de um espaço público comum para encontrá-los - um mundo politicamente organizado, em outras palavras, no qual cada homem livre poderia inserir-se por palavras e feitos.

É necessário criar esse espaço de ação entre os jovens....

Para que os adolescentes pudessem deixar de cometer infrações foi fundamental sentirem-se apoiados por outro ser humano. A confiança depositada neles por outro ser humano foi a força que os fez examinar sua história de maneira a reconstruir os determinantes que os levaram a tomar certas atitudes. Eles passaram a ter novas formas de estar no mundo.

Pelas entrevistas com os adolescentes foi possível perceber que é esse sentimento - o de confiança em outro ser humano - que faz com que os adolescentes deixem de cometer as infrações. Esse é o princípio do resgate.

O resgate de cada um só ocorreu quando o sujeito se tornou ativo na história da própria vida, e sempre na presença do outro que o humanizou. Foi possível resgatar experiências passadas, viver novas possibilidades para o futuro e se tornar visível como se é.

A ação coletiva, a participação do jovem com outros adultos levou-o a tomar novas atitudes frente a velhas questões. A contradição social passou a ser encarada, os conflitos foram vividos para proporcionar a superação das contradições e não o seu aprofundamento. A superação da contradição pressupõe a transformação de todos os envolvidos no processo. Os jovens e os outros que confiaram neles. 
Conforme foi apontado ao longo desse trabalho e afirmado no texto "Homicídios de crianças e jovens no Brasil: 1980-2002" produzido pelo Núcleo de Violência da USP (PERES, CARDIA, SANTOS. 2006. p.26) "os dados sugerem que ao redor do mundo os jovens são mais vítimas de homicídios do que agressores". Torna-se imperativo ver o que está acontecendo com a juventude brasileira.

Novas formas de ser precisam ser criadas e incentivadas. As contradições dessa sociedade podem ser superadas nas brechas apontadas por essa mesma sociedade. O novo mundo possível se dará a partir das possibilidades advindas do mundo de hoje.

A quebra da invisibilidade perversa promovida pelo cometimento do ato infracional só pode ocorrer com mudanças na legislação, no comprometimento com as já existentes, com maior atenção do poder público, com mudanças de opinião influenciadas pela mídia e baseadas em pesquisas acadêmicas e por experiências bem sucedidas que ocorrem pelo Brasil todo.

"Segundo Cardia e Schiffer (2002), o acesso a direitos como saúde, educação e lazer são fatores de proteção da violência" citado por (PERES, CARDIA, SANTOS. 2006. p.211). O Estatuto da Criança e do Adolescente e a Constituição Federal estão sendo desrespeitados em seus fundamentos: o direito a vida.

Essa nova forma de estar no mundo ocorrerá quando a escola cumprir com sua função de ensinar a todos os conhecimentos acumulados ao longo da história da humanidade, quando o trabalho puder garantir o desenvolvimento do sujeito e devolver o sentimento de pertencimento a um mundo cuja história não possa ser camuflada pela ideologia.

Quando o sentimento de solidariedade entre as pessoas puder existir plenamente, quando as relações entre pessoas não forem transformadas em relações entre objetos, quando a aparição pública de homens livres puder acontecer. Quando o homem puder se tornar humano. 
Nas últimas décadas do século XX e início do XXI não há mais utopias coletivas. Os jovens de hoje preocupam-se com a sobrevivência do dia-a-dia, com a necessidade de garantirem seu sustento e de sua família, com a falta de condições mínimas de existência individual. Cada indivíduo aprendeu que deve ser empreendedor e eficiente para a conquista de objetivos. A política do "cada um por si” vigora com força.

Lucas fala da rebelião do dia-a-dia. Esse relato motivou o título dessa dissertação pela importância que apareceu em seu discurso.

Rebelião é luta, é trabalho, é conquista. Para ele, vencer a rebelião é poder descansar depois de um dia inteiro de sufoco.

É... esse caminho bate na porta da sua casa, esse caminho bate, todo dia, todo dia bate, então.... pra você ser forte é difícil, é difícil... que nem numa rebelião, uma rebelião você... não é, o pessoal fala, uma rebelião é dentro de cadeia, não... rebelião é o dia-a-dia, entendeu? Rebelião é o dia-a-dia.... cada dia você tem que vencer uma rebelião, senão você..... perde ela completamente....

[Como que é essa rebelião do dia-a-dia?]

Rebelião no dia-a-dia é você.... é você acordar... saber que você.... saber que você pode conseguir um trabalho, ou se você tem um trabalho, você vai pro trabalho, faz seu trabalho, volta pra casa, se tá.... ao deitar da noite se está tudo bem, entendeu? Não aconteceu nada com a sua família, não levou uma bala perdida, não levou isso e aquilo, não foi roubar, não foi fazer nada... isso é uma rebelião, entendeu? É você vencer o dia, entendeu? Você não deixar o ... tipo.... o capeta te dominar, porque .... assim, mesmo... mesmo, tipo.... você tendo.... você tendo as coisas, você quer ter mais, você quer ter mais, então... toda hora vem aquela maldade no seu pensamento, então você tem que matar aquilo, entendeu? Você tem que matar... então eu acho que isso é uma rebelião.... uma rebelião da sobrevivência do dia-a-dia, tipo que nem... até seu próprio vizinho, até no seu bairro mesmo, que... como que a gente diz, na cadeia, acontece alguma coisa você debate, você debate... entendeu? Se o maluco está errado, se você está errado, você passa pelo errado e... tá tudo bem, entendeu? Tipo, tudo bem naquele termo, né? Não está nada bem, mas também não está tão difícil ... e aqui fora é tipo, aconteceu alguma coisa, você vai debater, não tem debate, não tem debate, é bala que rola, entendeu? Ou você morre ou você sobrevive, entendeu? Aqui fora é assim. É isso que é uma rebelião, entendeu? Lá dentro você tem que ser humilde, aqui mais humilde ainda, você tem que saber levar as pessoas, tem que saber conversar com as pessoas, mesmo... mesmo você não querendo, tem sempre aquele que quer desarrumar com você. (...)

Então você tem que fugir dessas.... ocorrências pra não dá fruto, entendeu? Pra não dá fruto porque você acaba se prejudicando, entendeu? Mesmo.... ou você acaba apanhando ou você acaba matando a pessoa e quem se 
prejudica mais é você, você pode se prejudicar você indo preso, entendeu? Ou senão você consegue fugir pra você.... é só mais um, entendeu? Isso que eu acho que é a rebelião do dia-a-dia, entendeu? A gente tem que ocorrer com tudo isso, e isso daí acontece com todo mundo, tipo você tem um carro, você sai daqui, ali em um farol, neguinho vai e te assalta, entendeu? Isso é... é uma rebelião perdida... você perdeu o que você lutou pra pagar pra .... porque ali você não vai ter de volta, se a polícia não consegue pegar, você nunca mais vai ver seu carro, entendeu? Eu acho assim....

(...)

A periferia você aprende dentro, entendeu? Dentro da periferia mesmo, você aprende lá dentro, porque fora você não aprende nada, sua mãe chega e fala "ah.... o mundo é perigoso, neguinho mata...." mas você nunca viu, sabe? Aquilo ali é só uma fala pra você, você nunca viu acontecer, você vê pela televisão, mas você nunca viu na sua frente, você não... nunca teve uma reação diferente, então ali você... você vê ali, você pô.... você está ali conversando, de repente chega um e pá, matou o maluco aqui na sua frente, entendeu? Isso acontece diariamente.... entendeu? Então eu mostraria pra ele qual que é o mundo, dentro da própria comunidade, dentro da periferia, como a gente fala, e mostraria pra ele o mundo fora disso, como se diz? Oportunidades, entendeu? Tipo ah, você quer ser jogador, ah você quer ser radialista, você quer ser isso e aquilo, você tem que estudar, tem que aprender, pra conseguir seu futuro mais pra frente, entendeu?

[Não tem saída na comunidade?]

Você tem que sair dali, é... ali a gente... pô, tem que mostrar pra ele como que faz pra ele sair dali, senão... se ele ficar nesses pensamentos ele nunca vai sair dali, entendeu? Nunca vai ter um... uma vida fora, nunca vai ter um conhecimento fora.... (Lucas)

Vicentin (2005. p.40) afirma que a rebelião é "[...] confronto e oposição, mais ou menos violentos, ao estabelecido". Lucas chama de rebelião o fato de conseguir estar vivo, vencendo as dificuldades do dia-a-dia. Rebelião para ele é vencer a morte, ou a cadeia, ou a possibilidade de se desentender com alguém. Para ele, rebelião é não perder o que conseguiu conquistar depois de muita luta.

Trassi (2006. pp.252 e 253) nos fala do atual presente contínuo, onde as necessidades precisam ser satisfeitas imediatamente com a aquisição de algum objeto, como se a felicidade pudesse ser comprada.

A luta parece individual, mas não é. Todos deveriam lutar pelo direito de ser humano. Com a presença de outros humanos nos humanizamos. Precisamos uns dos outros para essa conquista! 
As análises provenientes dos conceitos de exclusão social, fetichismo da mercadoria e condição humana; o conhecimento sobre os adolescentes que cometeram atos infracionais, tanto através de estatísticas como por meio das histórias pessoais contadas pelos jovens entrevistados; o conhecimento das leis que fundamentam uma forma de ver esse público e a importância da análise da mídia quando o alvo eram crianças e adolescentes construíram uma teia de significados para a prática infracional de adolescentes.

$\mathrm{Na}$ sua maioria, os adolescentes que cometeram atos infracionais eram filhos de famílias de baixa renda, moradores das periferias das grandes cidades, sofreram inúmeras violências e humilhações ao longo da vida. Foram influenciados drasticamente pelo desejo de obter mercadorias para sentirem-se presentes e atuantes em sua comunidade. Não tiveram ou não puderam perceber a presença de pessoas que os auxiliassem na conquista da confiança necessária para construírem um modo de ser e existir que buscasse os valores da solidariedade, da participação e da convivência em prol dos direitos e garantias da condição humana.

Muitos adolescentes provenientes de família em boas condições econômicas e de moradia, com bom acesso a educação e saúde, em que a renda dos pais pode garantir a sobrevivência em todos os aspectos necessários para a criação dos filhos, também vêm cometendo delitos.

Seria necessário um estudo aprofundado sobre os adolescentes com esse perfil, mas com certeza pode-se afirmar que nesses lares os laços familiares estavam esgarçados, o respeito à tradição e a uma cultura da solidariedade não estavam atuando. $\mathrm{O}$ desejo de mercadorias fetichizadas, $\mathrm{o}$ consumo de mercadorias que mudam a cada instante, as relações coisificadas entre as pessoas estão presentes também na vida dos que possuem renda.

A vivência em um mundo em que o consumo é a base para o pertencimento a um grupo, em que as relações sociais estão coisificadas, o sentimento de ausência de confiança nas pessoas impera, em que há impossibilidade de ser diferente do que foi estabelecido por uma minoria para 
que todos sejam iguais, onde não existem espaços em que a palavra e a ação de homens livres possam prevalecer foram apontados por esse trabalho como fundamentos da impossibilidade de constituição da condição humana. 
ANEXOS 
ANEXO A - ENTREVISTA ALEX 
Transcrição entrevista Alex

23 anos

Entrevista concedida dia 31/10/2006 no local de trabalho do depoente.

A. Mas você tem as perguntas aí, Vanessa?

V. Tenho, na realidade eu vou fazer pouquíssimas perguntas, eu quero mais é te ouvir (rsss) Mas a idéia é o seguinte: eu queria que você me contasse um pouco, primeiro no geral sobre....

A. Tá gravando?

V. Tá gravando....já começou.... No geral sobre a sua vida, onde você nasceu, como que era? Dá uma passada...

A. Rápida? Tá... Vamos ver por onde eu começo.... Então, eu nasci em Fortaleza dia 21 de novembro de 1983, vim pra São Paulo eu tinha mais ou menos um ano e meio, minha família toda, tenho dois irmãos, um irmão e uma irmã, casados já, tenho 4 sobrinhos, mas aí eu já estou adiantando....

V. Não... pode falar...Você é o mais novo?

A. Sou o mais novo, caçula... Bom, vim pra cá com um ano e meio, é.....meus pais, meu pai, minha mãe estava desempregada quando chegou pra cá, meu pai estava trabalhando. Porque minha mãe trabalhava num hospital lá em Fortaleza, trabalhava já tinha 8 anos, aí ela pediu as contas pra poder vir pra São Paulo, porque achava que a vida aqui seria melhor e meu pai também achava ... que aqui... eu teria, é... teria uma vida boa é.... sobre cuidado de médico, seria mais fácil o acesso a medicamentos, que em Fortaleza era precária as coisas assim. Bom.... acho que.... minha infância.....

V. Aí vocês vieram morar onde?

A. Aqui em São Paulo na região de Itaquera.... na Cohab 2.... Aí... é.... aos 15 anos mais ou menos... ou tô adiantando demais?

V. Não, pode falar!

A. Aos 15 anos meus pais se separaram, antes meus pais já queriam se separar quando eu era mais novo, mas eles esperaram eu crescer mais um pouco pra.... aliás, os meus irmãos e eu, crescer mais um pouco, ter uma idade maior pra.... pra poder se separar porque... achavam que, meu pai e minha mãe achavam que tinha que esperar a gente crescer, ter uma cabeça pra ver com quem a gente ficava no dia que eles resolvesse se separar...

V. Queriam que vocês escolhessem?

A. É.

V. Tá

A. A gente tinha que ter a própria cabeça de escolher com quem queria ficar. Eu acho que, era o caçula, não sei.... acho que por isso eu também sofri .... é.... por causa que na minha mente eles dois tinha que ficar junto de qualquer maneira, porque eu não conhecia muito bem, eu não sabia qual que era o motivo. Mas um dia eu descobri porque que era os motivos.... os motivos era porque o meu pai batia muito na minha mãe, bebia demais e brigava muito... e quando a minha mãe começou a trabalhar, meu pai falava que ela ia... ela começou a trabalhar e de repente começou a estudar também, né? Pra poder acabar os estudos e... começar uma nova vida aqui em São Paulo... E aí meu pai xingava ela, falava que ela era uma vagabunda... que ela não ia trabalhar, ia ficar com outros caras..., outros homens, traía ele, não sei quê. Isso meu pai bêbado falando. Ele falava isso pra minha mãe e aí minha mãe foi ficando com 
raiva e acabaram se separando quando eu tinha..... 16 anos... é isso, 16 anos mais ou menos.... minha mãe.... eu tava falando do que mesmo? Ah, que eles se separaram.... separaram....pelo motivo que eu já disse, né? Tá bom, então... vamos lá deixa eu vê... Tá, minha mãe foi morar em Cidade Tiradentes e meu pai ficou em Itaquera... aí meu pai virou evangélico, virou evangélico, parou de beber... e tudo... e aí eu continuava com a mesma mente que era de que eles tinham que ficar junto, que não entrava na minha cabeça, e aquilo... mas também a minha mente ia me corroendo porque eu sabia que o meu pai batia muito na minha mãe e às vezes brigava com ela, minha mãe até ia dormir com a gente no mesmo quarto que eu e meus irmãos por causa que meu pai tava bêbado, apesar que minha mãe bebia também, ainda bebe até hoje, bebe mas é a cerveja dela lá....(rsss) Mas... acho que ela nunca conseguiu conviver com isso, também acho que ninguém gostaria de ficar apanhando do marido, mas meu pai tá mudado, é evangélico hoje.... Mas nessa época eles se separam e aí foi... foi quando eu acho que....eu tive... eu tive muitas amizades é com o pessoal que cresceu junto comigo assim, que eram amizades boas assim e eu não sabia quanto era valorosa aquelas pessoas que cresceram juntos e aí eu conheci outras pessoas que não eram as mesmas pessoas que cresceu junto comigo. Bom aí.... essas pessoas eram da escola, na escola eu acho que tem sempre aquele grupo que é mais bagunceiro, né, e eu era daquele grupo bagunceiro, era do grupo do bagunceiro, bom acho que a gente queria experimentar outra coisa, outra.... uma adrenalina maior do que só bagunçar na escola e tentar dominar a escola, de uma certa maneira....

V. Você estava em que ano nessa idade, nessa época?

A. Nessa época eu tava na sétima série já. Não lembro o ano, mas sétima série... e eu não... aí eu comecei a não ir pra escola mais por causa também desse grupo....

V. O que vocês faziam?

A. Bom a gente... Nossa, a gente bagunçava muito na escola, mas não tinha chegado a época de usar drogas.... a gente bagunçava muito e.... a gente xingava as professoras e.... ia expulso da escola e ia.... ia pras ruas e meu... e a gente mexia com todo mundo e ninguém.... era uma época boa sim, época boa de bagunceiro mesmo, a gente aproveitava bem a infância e a adolescência.... Bom, deixa eu lembrar.... A gente jogava uma bola, mas a gente era o grupo que os... que o pessoal da nossa idade tinha mais medo... e a gente jogava bola, e o pessoal jogava bola com medo da gente, assim... e isso era estranho, era estranho e ao mesmo tempo .... é... nós se sentíamos bem de tá, tá meio que dominando o espaço assim....

V. Eles tinham medo por quê? Você lembra? O que vocês faziam que amedrontava o povo?

A. Eu acho que quando a gente arrumava briga, a gente sempre era o mesmo grupo e ninguém mexia com a gente, quando mexia com um mexia com todos, então quando a gente pegava pra bater era todos contra aquele e era uma covardia tremenda, mas a gente achava engraçado, achava bom e acho que era por isso, mas é... teve uma época que aí começou um... um conhecer outras pessoas e trazer a ..... a droga pra gente, ...pra dentro daquele grupo, foi a maconha. Aí todos começaram a experimentar, alguns não gostavam, mas mesmo assim experimentava só para ver como era o gosto.... bom.... deixa eu lembrar mais....

V. Você chegou a experimentar nessa época?

A. Ah sim.... fumei maconha até os meus... 19... 18 anos, deixa eu ver.... não, é, até os meus 18 anos... até os meus 18 anos fumei maconha, nunca tive... já experimentei outras drogas mas... nunca tive vontade de continuar usando...foi só a maconha que eu usei bastante tempo, mas também ... não me agrada, não me agrada... não mais... 
acho que já faz, deixa eu ver... com 18 , já vou completar 23... cinco anos, né? Cinco anos sem usar nenhum tipo de droga... (rsss) às vezes eu bebo socialmente (rsss)... tomo uma cervejinha... bom, vamos voltar lá atrás de novo.... já passei da escola, tava na... no.... na primeira série do colegial, do colégio... nisso eu já tinha repetido, já a sétima, a oitava e o primeiro, só que eu tinha feito aquele...., aquela história que tem de janeiro, que eram... tinha um negócio em janeiro, que era férias de janeiro, só que você não tirava suas férias de janeiro você acabava estudando para poder passar o ano que você repetiu... recuperava o ano perdido, em janeiro e isso eu fiz da sétima, a oitava, o primeiro, aí eu fui... eu fui preso no dia... aí eu fui preso... antes de eu ir preso já tinha feito outros assaltos, né, tinha feito outros assaltos e meu primeiro assalto foi no mercado perto de casa... onde a gente só pegou moeda, não sei porque a gente tinha o caixa na nossa frente, mas a gente não pegou o dinheiro da mulher... tinha uma mulher e um senhor... o senhor acho que era pai da mulher, mas não era um velho assim de idade, mas era um senhor, um senhor... aparentemente com seus 39,40 anos, assim 38.... Bom, e a gente assaltou com uma arma de brinquedo... era.... uma 765 que... é uma.... a gente chamava de quadrada, não mas era uma 765 e era de plástico e era azul ela... só que dava pra saber que era de plástico, só que o que a gente fez, a gente pintou ela de preto... pintou de preto pra disfarçar pra gente poder assaltar aquele mercado.... e.... aquilo eu acho que... se tornou fácil demais na primeira vez... virou uma coisa instigante assim, de adrenalina.... de todo aquele grupo reunido, acho que a gente tinha sete, sete meninos assim adolescente que em vez de jogar bola é... partir pra outras brincadeiras... a gente ia começar a brincadeira de roubar os outros pra gente não depender mais da... dos nossos pais... porque... eu acho que todos tinham... o mesmo... a mesma cabeça... de que.... por mais que a nossa família tivesse assim... passando uma necessidade, a gente já tava com a cabeça assim... que a gente tinha que ser homem, homem é... pra poder já sustentar a família, mas não querer trabalhar, porque na época era só diversão, né.... Bom e aí a gente fez o primeiro assalto, eu e aquele grupo, que não era o mesmo grupo que cresceu junto comigo, assim, era o grupo da escola, a gente começou a faltar, assaltamos o primeiro mercado, pegamos só um saquinho de moeda, que era... que tinha muito dinheiro naquelas moedas, e a gente não pegou as notas do... da mulher nem do tiozinho lá.... Bom aí a gente foi contar as moedas, não lembro quanto tinha, mas foi muito pouco e a gente ficou super feliz assim de ter o nosso próprio dinheiro, sem precisar que nossos pais dessem.... dessem esse dinheiro pra gente....

Bom, o segundo assalto, o segundo assalto também foi o mesmo grupo, só que numa, só que foi mais reduzido, a gente fomos em quatro pessoas pra Av. Paulista, e nisso foi uma saidinha de banco. A saidinha de banco era na verdade assim, a vítima estavam dentro do banco e aí... uma pessoa de, de nós quatro, daquele grupo de quatro adolescentes, um ia, entrava dentro do banco e ficava olhando essa pessoa, essa vítima, que ia ser a vítima futuramente, é... o quanto ela sacava de dinheiro o quanto que ela colocava o dinheiro no bolso, por exemplo se era uma pessoa que sacava quinhentos reais e colocava no bolso, a gente esperava uma pessoa sacar mais, esperava sacar mais, era sempre acima de mil reais, a... essa pessoa que estava no banco esperava pra poder dar um sinal pra gente e aí saía atrás dela, saía sempre atrás da pessoa e aí fazia um gesto que era encher a boca assim, sabe, assim, encher a boca ou de repente dar uma piscada... tinha algum gesto, algum código que dizia quem era e aí um chegava perto dele e ele falava: "ó, tá de camiseta azul, tá de boné branco, tá de chapéu, tá de óculos, tá de tênis vermelho", alguma coisa que destacasse da população que estava em volta... e aí a gente ia atrás e ele, essa pessoa 
ficava só em volta porque ele já tinha escalado, já tinha feito a parte dele, né? Então os outros três ia pra... como a gente chamava, pro recolhe... que era o.... que era o... pegar do dinheiro, chegar na pessoa e a gente estava armado nesse dia, mas a gente tava com a arma, com a mesma... com a mesma arma de brinquedo preta pintada de guache. Bom essa vítima entrou dentro do.... entrou no metrô.... quando ela passou a catraca a gente deu voz de assalto, e eu dei voz de assalto, e eu que estava com essa arma de brinquedo, acho que foi a primeira vez que eu cheguei e dei voz de assalto, porque da outra vez era aquele grupo e o grupo só chegou, mostrou a arma, pegou e foi embora, agora não, agora a gente já estava meio especializado em dar voz de assalto, pra pessoa já se sentir intimidada e a gente já pegar o dinheiro que estava com ela, e ela estava com o dinheiro no envelope, uma parte no envelope e outra parte no bolso. E aí chegamos os três, eu agarrei essa vítima que era um homem, que eu não lembro se ele estava de óculos ou não, mas era... era um homem, eu agarrei ela pelo pescoço e pus o... a arma na cabeça dela e falei que era um assalto que a gente queria só o dinheiro, se ela quisesse ir embora ia ter que dar o dinheiro. Nisso, as outras, as outras duas pessoas que estavam comigo, eram em três, um tava esperando e os outros dois estavam comigo, era... as duas pessoas pra pegar o dinheiro e um pegou a arma pra levar embora, né? Que aí eu ia sair andando, se eu fosse preso eu não estava com o dinheiro nem estava com a arma e se eu fosse preso também eles tinham que dar dinheiro pra minha família, pra minha família poder me visitar e... isso já tava tudo programado, já tava tudo combinado, e assim.... eu não sei como a gente teve essa idéia de combinar tudo antes, porque eu não lembro de ter ninguém com experiência nisso, que estava junto com a gente, saiu do grupo, eu não sei se tinha amigos da gente que deu essa... essa idéia, mas eu acho que foi isso, de alguma forma essa idéia veio de outra pessoa, de outra pessoa fora do grupo, que deu a idéia pra gente de combinar tudo certinho antes de.... de chegar pro assalto. Bom. Isso foi na Paulista... Tem quanto tempo?

V. Dezenove minutos.

A. Isso foi na Paulista.... só que nesse dia eu não fui preso.... a gente pegou o dinheiro, eu saí correndo, depois que eu vi que eu estava subindo as escadas, estavam dois policiais descendo as escadas, eles me viram correndo, mas acho que eles não.... não.... não se ligaram que eu estava, que eu tava saindo do assalto e tava correndo, nisso já vinha outros dois... é....correndo também, aí eles se ligaram, pularam a catraca e aí vieram atrás da gente, a gente se separou e a gente tem sempre, a gente marcou um encontro que era na.... Associação, a gente chamava Associação que era um clube de esportes, lá na... lá em Itaquera na Cohab 2 que era onde eu morava, e era feito o nosso ponto de referência, onde a gente fumava maconha, onde a gente combinava qual que era o próximo assalto, bom, e aí eu, é.... eu vi os policiais atrás de mim na Paulista eu entrei numa rua, é... ah, não me lembro qual, mas assim, estava muito movimentada, o que que eu fiz, eu me abaixei, eu me abaixei, e como que estava muito movimentado acho que eles não viram, na hora que eu vi que eles estavam procurando eu levantei assim de trás de uma mulher, eu levantei de trás da mulher e andei normal pra frente assim, longe deles assim.... depois disso entrei no metrô, cheguei em.... cheguei em casa, meio trêmulo, assim com medo, pensando que... o... que os policiais estavam indo atrás de mim, ou já sabia pelas câmeras, ou meu rosto já estava em... em qualquer lugar aí na delegacia... bom, mas isso não aconteceu e acho que isso que me estimulou a ... a querer mais, porque eu não fui preso da primeira vez, não fui preso da primeira vez, não fui preso da segunda, e aí no dia....não eu, ainda... fiz alguns assaltos antes, eu fiz assalto a Lotérica, a gente 
assaltou uma Lotérica perto de casa, assaltamos a Lotérica perto de casa, eu e mais quatro pessoas, sempre o mesmo grupo, sempre alguns desse grupo, muitos tinham umas pessoas por fora porque a gente era como se fosse uma... uma lei assim que não entrava mais gente pra assaltar com a gente, a gente convivia com outras pessoas que também assaltavam, nisso a gente já tá em outro tempo, começamos a conviver com outras pessoas que assaltavam também, mas a gente sempre assaltava o mesmo grupo, como parceiros, amigos de escola viraram parceiros, que já não ia pra escola, já não queria mais saber de nada só queria saber de dinheiro, de assalto.... de viver no meio da malandragem e de sentir que as pessoas tinham medo, algumas pessoas tinham medo da gente.

V. Isso vocês sentiam como legal?

A. Isso a gente se sentia bem com isso, porque.... era uma forma de criar um certo respeito..., criar um certo respeito no meio da... da comunidade, no meio da malandragem, a gente tinha um certo respeito, porque a gente já, desde pequeno, desde os 15 anos a gente já tava começando a roubar, assaltar e... a gente fez isso sozinhos, sozinhos que eu digo, não precisou de ninguém que já estava no meio do crime pra gente poder começar a assaltar. Bom a gente foi no assalto a Lotérica... perto de casa, perto dessa Associação, do clube de esportes, e aí tinha um segurança que estava com um cachorro, que era aqueles cachorros grandes.. sei lá rottweiler, tipo Pit Bull, é aquele cachorro preto e marrom, como que é...

V. Pastor?

A. É, Pastor Alemão...é, esse mesmo, que era um bicudo assim.... Bom, e aí a gente chegou.... nessa época, ó, a gente já tinha feito outros assaltos e já tinha comprado agora uma arma de verdade, que era um... 38, um três oitão, mas a 765 de brinquedo sempre ficou guardada em alguma casa de algum daquele grupo, que ficou guardada porque se a gente perdesse a de verdade a gente ia... ia roubar com a de brinquedo, mas a gente fez o assalto na Lotérica... foi tudo cena rápida, de não ligar pra câmera, de não ligar pros rostos das pessoas que estavam, que eram perto de casa e sabia que a gente morava ali perto, que a gente passava ali de... a pé, a gente passava ali, se locomovia porque era perto também da minha casa, eu tinha que dar a maior volta pra ir pra minha casa, não, eu ia pela Lotérica. Mas eu sempre passava por lá e não tinha medo que as pessoas me conhecessem ou não, mas assim, a gente fez esse assalto sem ligar pras câmeras e sem ligar pras pessoas que eram, não sei às vezes eu acho que era, não sei, até morador de perto porque a Lotérica era perto.... e aí tinha esse segurança que a gente... tinham 2 que enquadrou ele e falou que... chegou pra ele e falou que se o cachorro latisse ou mordesse alguém, ia matar o cachorro e ele, e ele acabou ficando piano, e ele trabalhava armado, a gente acabou tomando o revólver dele e assaltando a lotérica, a gente mandou todo mundo pro chão, tinha umas pessoas muito com medo, já chorando, gritando, a gente pediu pra elas ficarem quietas, mas mesmo assim a reação das pessoas era... era extremamente amen..., amedrontosas enquanto a gente tava fazendo uma coisa assim... que pra nós já tinha virado diversão, já era como roubar doce de criança, mesmo que ela grite, você pega o doce e sai correndo (rsss) e não liga pra ela, assim...Mas... é....e meu pai, nesse dia... que eu tinha assaltado, cheguei em casa com dinheiro.... e meu pai ficou sabendo desse assalto na Lotérica e ele já estava sabendo que eu estava fumando maconha porque eu chegava muito louco também em casa, nisso meus pais já estavam separados, minha mãe morando na Cidade Tiradentes e meu pai na Cohab 2, só que eu morava com o meu pai porque eu estava estudando lá e de final de semana eu ia pra Cidade Tiradentes com a minha mãe e... meu pai... descobriu de alguma 
forma que tinha sido eu que tinha assaltado lá, né.... e aí ele começou a falar que eu era vagabundo, que eu era um bandido safado, que eu não queria... que ele não queria bandido dentro da própria casa dele... só que....mesmo ele falando isso, ele nunca me expulsou a pontapé da casa dele, assim... e minha mãe não sabia disso, enquanto estava na Cidade Tiradentes não sabia desse assunto, assim, e nunca soube porque eu nunca falei. Meu pai também nunca disse disso aí, na verdade ele descobriu, mas eu sempre tinha dito que não tinha sido eu, que eu não assaltava, que não era bandido, que eu comprava minhas roupas com o dinheiro que ele dava, que era o pouco dinheiro que ele dava que, só que eu comprava roupas caras, que eu falava que era um valor abaixo, que deu pra comprar com o dinheiro que ele me deu....

V. Ele desconfiava, mas....

A. Ele desconfiava, mas ele não sabia... até que quando eles acreditaram foram na vez que eu... que eu fui preso, fui preso a primeira vez era 12 de outubro de 1999, 12 de outubro de 1999 que eu fui preso a primeira vez, nossa! Como eu chorei, viu? Chorei igual criança, chorei igual criança, eu fui preso na .... na Paulista, fui preso na Paulista, era na... perto da....

V. Feriado....

A. Não, feriado?

V. É, 12 de outubro, não era?

A. .....não, não era um feriado, então não foi 12 de outubro, ... foi 19 de outubro... 12 de outubro é dia das crianças? Não, não foi, foi depois... foi depois porque eu ainda comprei... eu comprei um presente pro meu primo... pro meu primo, porque ele tinha problema de... aqueles ataques que dá, é.....

V. Epilepsia?

A. Isso, isso mesmo, e p i 1 e p s i a, nossa, nome complicado! Então, eu dei um presente pra ele que era um vídeo-game, só que ninguém sabia de onde tinha tirado aquele dinheiro pra comprar o vídeo-game, aí eu falei....mas o vídeo-game que eu comprei não era novo, eu falei que era da feira do rolo. Bom, a gente foi pro assalto na Paulista de novo, eu.... era no Banco Safra, tinha até uma escada rolante assim, no Banco Safra .... era perto da Brigadeiro, ali, era a Brigadeiro com a Paulista se eu não me engano.... não sei se era Brigadeiro com a Paulista ou era perto da TrianonMasp... o Banco Safra....Bom, mas me lembro que o cara que estava com a gente, ele entrou de terno e gravata e de óculos pra dentro do banco e entrou com a..., nisso a gente já tava, já tava bem estruturado porque a gente entrou com a Glock...

V. Entrou com o quê?

A. Com uma Glock, é uma arma... é uma arma é.... que ela é toda, como se fosse toda emborrachada, assim e ela passa pelos mecanismos... ela não apita no banco...

V. Como vocês conseguiam essas coisas A.?

A. A gente se revolucionou agora... a gente conseguia através do... a gente já estava dentro, bem estruturado no crime que era, que a gente já conhecia alguns que era mais velho no crime, começou assim... é basicamente igual com a gente... igual com a gente não, igual, é... não ao mesmo tempo que nós, do nosso grupo, mas já eram mais velho, mas começou desde adolescente também, eram mais velhos no crime, assim... e aí eles tinham dinheiro, tinham carro, tinham moto, e aí eles eram traficantes também, e aí a gente comprava arma com o dinheiro do nosso assalto.... comprava arma deles.... Entramos com a Glock, foi a primeira vez que... que o cara do nosso grupo entrou com a Glock, com a Glock dentro do banco, com a arma dentro do banco... e a gente já tava vendo, como que a gente conseguiria assaltar um banco, mesmo esse dia, porque conseguiu entrar com a arma, a gente pode entrar 
com 4 armas e tentar assaltar um banco, mas isso aí, péra lá que a gente vai chegar.... a gente tava esquematizando pra assaltar um banco, já.

V. Nesse dia era a tal da saidinha?

A. Nesse dia era a tal da saidinha, pra que? Ninguém ia gastar o dinheiro que a gente sempre dividia, ninguém ia gastar o dinheiro que a gente ia comprar arma e droga, comprar arma e droga....ia, aí a gente fizemo a (?) e ganhamo 4 mil e 500, nesse dia que era de um boy que estava trabalhando, foi pegar... provavelmente deve ter pegado dinheiro da empresa pra pagar seus funcionários, ou pra pagar alguma conta da empresa e a gente acabou assaltando esse, esse funcionário da empresa que era um boy, né? Que é aquele... é o ...é o cara da empresa que faz o... leva documento, faz pagamentos... e aí ele não estava fazendo pagamento, ele sacou esse dinheiro, ele sacou esse dinheiro e esse cara que estava de terno e gravata, com... com a arma na cintura é... a gente falava que ele ia escalar a vítima, ele escalou a vítima que era a.... que era escolher a vítima e a quantidade de dinheiro, quem que era.... e aí ele deu o sinal pra gente e eu não pensei duas vezes em ... em por a arma... a gente já tava com um oitão que era do cara da Lotérica, que era o cara da Lotérica, que era um oitão que era Canela Seca... é um 38 que ele é mais fino, se não me engano.. que eu não entendo mais, que eu nunca mais peguei numa arma, assim, mas se eu não me engano ele tinha 5 tiros assim, no tambor e ele era fino, assim, um pouco grande e o cabo, acho que chamava de Canela Seca porque o cabo era muito fino e era, era muito ruim.. (rsss) era muito ruim.... e aí eu meti.... eu coloquei a arma sobre a cabeça da... do cara, que era... como a gente falava era... eu meti a peça na cabeça do Beco e... dei a voz de assalto... e aí a gente.... o cara tipo... tinha mais um cara com a gente, nesse dia a gente tinha ido em 3 só, e aí o que tava com nós fez o recolhe, que era pegar o dinheiro e pegar minha arma e sair correndo, só que nesse dia, tinha uma banca de jornal que tava bem escondida, tinha uma viatura vindo na faixa que era de ônibus e tava vindo, tava vindo de contra mim, só que eu... eles não tinham visto eu assaltando a vítima, na hora que eu pus o revólver na cintura que eu pus a peça na cintura eles... deram aquela sirene que fez uieuie lá, uieuieuie (rsss) eu lembro e aí eu... eu não tinha nenhuma bala dentro do revólver, não, minto, eu tinha uma bala dentro do revólver e aí eu jog... dei um soco na vítima, peguei ela e joguei assim ela... enquanto o cara que tinha ficado com a Glock, que tinha.. que tinha bala, já tava na outra esquina, não tinha como, não tinha como ele, na verdade não tinha como ele vir, né... que eu era de menor também ele não...a gente falava que mesmo... que de menor não precisa se arriscar tanto pra... pra salvar um outro, só se estivesse bem próximo, bem junto, só que ele saiu... saiu e foi pra casa e o outro que pegou minha... que pegou o dinheiro também foi... foi pra casa....

V. Essa história de porque era de menor, porque que era isso?

A. Por causa que... que menor a gente achava que.... a gente achava não... o menor ficava bem pouco tempo que o de maior, e o de maior perdia a vida enquanto era preso a primeira vez, perdia a vida não, em assim, não conseguia mais um trabalho... não conseguia mais nada, e menor não, menor era sempre aquele cara que segurava todos os $\mathrm{BO}$ de... do grupo todo, se tivesse o grupo só de maior, o menor ia levar a peça, pegar o dinheiro, fazia tudo enquanto o de maior só escalava ou só chegava junto, dava um soco ou apavorava a vítima, pegava o dinheiro, mas o menor, se fosse preso os 4 e tivesse só um maior, tipo assim, três maior de idade e um menor, o menor era o que segurava o refrão, segurava o BO dos 4 e falava que ele estava com a peça, que não conhecia esses caras, ou conhecia mesmo, tava na rua, não sei que....inventava qualquer história pra que não fosse preso os de maior, porque se 
você levasse, se você caguetasse, que era... caguetar na gíria é... é você dedurar outra pessoa, né? Então... o de menor tinha sempre que ter uma história pra que os de maior não fosse preso junto com ele... é.... porque senão se caguetasse é... chegasse na Febem ou em ... ou não voltava mais pra casa, ia ser morto quando voltasse pra casa se não fosse morto na própria Febem...

V. Ia ser morto por quem, se voltasse pra casa? Pelo próprio grupo?

A. Pelo próprio grupo porque caguetou e levou os outros preso ou senão perdia o respeito no crime e nunca mais assaltava... nunca mais assaltava e nunca mais ia ter a convivência com essas outras pessoas, né?

V. Sua moral ia lá pra baixo?

A. É... também. E aí.. você não tinha... não tinha respeito na quebrada, não tinha respeito aonde morasse. Bom. E aí, esses policiais estavam vindo da banca de jornal e eu se.. joguei a vítima de uma tal maneira que ela estava... ela caiu no chão, era um.. um moleque da idade que eu tô agora, mais ou menos uns 23, 25 anos, no máximo assim, a idade de um molecão mesmo... Bom, aí os policiais tavam vindo, ligou a sirene, eu só tinha uma bala, eu apontei pra eles e atirei... eu não sei como eu tive a coragem, mas... eu acho que eu já estava com tanto... ódio assim de, de não ser preso... de, ódio de policial porque também na... nas ruas aonde que a gente ficava, a gente sempre era o mesmo grupo e aí... eles tinha meio que medo assim, porque quando a gente era... era abordado por eles, eles batiam e diziam que uma hora ou outra eles iam pegar e iam matar a gente.. não sei porque, acho que era porque, quando estava aquele mesmo grupo, aquele mesmo grupo fumando maconha, as pessoas que eram da região ali.. falavam pra eles... ligavam... denunciavam e ali eles vinham e via que era a gente que estava fumando maconha...

V. Eles batiam?

A. Se batiam? Nossa! muito... bom, mas depois eu volto nessa história... Aí eu atirei pra cima dos policiais... eles vinham em 2, só que eu vi que eles abaixaram a cabeça assim na viatura, só que eu atirei, atirei e não cantou... e não, e não consegui atirar que era a única bala que tava no revólver e aí eu desisti, atirei três vezes, as três vezes que eu atirei não saiu a bala, acho que se eu atirasse mais uma ou duas vezes, que eram cinco, né? Mais uma ou duas vezes eu ia... eu ia conseguir atirar a bala e sair correndo, mas ao mesmo tempo eu fiquei com medo, fiquei com medo, de repente eu atirar e matar os policiais e... de repente ser preso por homicídio, uma coisa assim. Eu corri, eu corri pra trás de um banco no estacionamento, só que era uma rua sem saída na Paulista... eu corri pra uma avenida, tinha um estacionamento do Banco do Brasil e nesse Banco do Brasil eu não sei se entrei no estacionamento ou era uma rua sem saída, sei que tava vários carros estacionados assim, não lembro se era estacionamento, mas parecia uma rua que era sem saída... eu escondi detrás do táxi, tinha um táxi estacionado aí eu fui pra dentro, pra debaixo do táxi... eu fui pra debaixo do táxi, só que aí tinha uns policiais, uns policiais da rua, né? que às vezes eles tavam até com... a gente chamava eles de mão branca porque eles eram... eles já eram policiais disfarçados é... vestidos normal e vocês não... nem se ligavam que eram policiais e a gente chamava eles de mão branca, não, vou chegar nessa parte de porque que a gente chamava eles de mão branca, porque eles tinham... com eles tinham um acerto, assim tinha um acerto de você dar um dinheiro e você não ir preso e nessa vez que eu fui preso eu tentei ainda fazer acerto com os policiais... de eu ir pra casa e chegando em casa eu tinha dinheiro, foi desse próprio assalto que era os caras que estavam comigo, só que eles queriam que eu caguetasse, falasse quem 
estava comigo e nisso eu apanhei pra caramba, no meio da Avenida mesmo, mó multidão de gente no meio da Av. Paulista..

V. Por esses mão branca

A. É..

V. Não pelos polícias que você tinha atirado?

A. Não, eles desceram também, eles correram atrás de mim, deixaram a viatura lá, lá na Paulista e correram atrás de mim só que quem me prendeu foi esses.... esses policiais vestidos à caráter, normal... só que eles também tavam junto e era como se fossem testemunhas... bom aí eles me levaram pra viatura e me fizeram... me bateram bastante até eu falar quem tava comigo. Eu falei, aí eu disse que eu tava com mais duas pessoas, mas eu não conhecia... que eu não ia falar de jeito nenhum, que eles não moram perto de mim, que eu conheci eles ali na Paulista, só que era tudo mentira, né? Que eu tinha conhecido eles na Paulista, é.... e que o revólver não era meu, era... eu tinha... eu tinha ... feito rolo na feira do rolo de Guaianazes que era perto da minha casa em Itaquera e eu não conheci o cara que tinha me.. que tinha me dado o revólver que era um rolo de um vídeo-game, mas isso tudo mentira... tinha pegado o revólver do segurança que era da Lotérica. Bom, fui preso dia 19 de outubro de 1999, é, 19 de outubro, 19 de outubro.... eu fui preso....isso..... eles me levaram pro.... pra delegacia, fizeram $\mathrm{BO}$, minha mãe veio, chorando, e eu estava algemado assim ó... num gancho, que era como se fosse num gancho de rede, de por a rede de praia, sabe? Só que era um gancho fechado assim, e aí eles me algemaram naquele gancho e prenderam meu pulso, mas me prenderam com tanta força que eu não conseguia nem mexer e meu braço tava no .... minha mão já tava ficando até roxa, porque não circulava, acho que o sangue, direito. Bom, nesse dia eu apanhei bastante que era pra eu levar os policiais até minha casa, que era pra caguetar as pessoas que estavam junto comigo, mas eu resisti a... , a toda a... a toda essa pressão de apanhar, de me baterem, torturar, de uma certa maneira e não levei ninguém preso junto comigo, assim, mas tinham pessoas que estavam junto comigo. E minha mãe tinha chegado nesse dia, que ela já sabia que eu.... a... os próprios colegas que estavam comigo foram lá e falaram pra minha mãe: “ó, o A. foi preso, ele está em tal delegacia", porque eles já são.. já sabiam, né?

$\mathrm{V}$. Tinha aquele esquema, tinha que ajudar a família a ir visitar....

A. É, tinha... aí esse dinheiro que a gente pegou, eles deram tudo pra minha mãe, não, minto, não deram tudo, deram.... 900 reais pra minha mãe, pra minha mãe se manter um pouco e... e ir lá me ver, me visitar, porque logo logo eu estaria na rua. Bom, depois da delegacia, que minha mãe já tinha ido lá, ela.... chorou bastante e ela teve um AVC, que é o derrame..... que é o derrame na.... bom aí ela... nesse dia ela teve um AVC foi direto pro hospital, não lembro qual hospital que ela foi, mas ela foi pra algum hospital lá próximo e..... e aí eu fui mandado direto pra UAI, né? A UAI é lá no Brás, Unidade de ..... Unidade de Atendimento Inicial... é isso mesmo. Que aí todos os menores antes de irem pra Febem, que é a Unidade Educacional, UE ou uma UAP, sei lá, antes de ir pra outra unidade passa pela UAI, ou às vezes, vai direto da delegacia pra.... pra própria Febem, mas não fica muito tempo na UAI, eu fiquei 12 dias na UAI e fui pra Raposo Tavares, a Raposo Tavares era a UE 28, Unidade Educacional 28, primeiro era UAP, Unidade de Acolhimento.... ah, não lembro o que era UAP.

V. Acho que o P é de provisória, Unidade de Acolhimento Provisório.

A. Que aí segura você por um tempo antes do seu processo, ser condenado, não sei o que.... e aí eu fui pra UE, Unidade Educacional. Bom.... é....lá tinha seus 
funcionários.... a gente teve.... acho que o momento mais crítico assim na Febem... nessa época, teve outros né, de apanhar...de não sei que, mas teve uma rebelião que a gente quebrou tudo e a Choque entrou, a gente teve que entrar pra dentro dos barracos antes que ela... que a Choque começasse a jogar gás, gás lacrimogêneo e começar a bater, só que nisso os barraco, os barracos ficaram aberto e a gente de coruja (cueca) e ficaram cada guard...um guarda.... dois guardas da Choque em cada barraco, assim... eram... 6 barracos, cabiam 12, 12 menores em cada barraco que eram 6 por $12 \ldots$ que dava $68 \ldots$ né?

V 12 vezes 6 é.... 72.

A. 72 ... 72 menores infratores.... vários art..... é......vários artigos tinha cada um, né? Bom, mas.... nesse dia.... e aí depois dessa, dessa rebelião, alguns fugiram, alguns menores fugiram... a Choque entrou e aí a gente... foram chamado todo mundo por nome no pátio, alguns faltaram porque... era os que... era os que já tinham fugido. Eu não quis fugir porque eu queria cumprir, cumprir pra ver se eu melhorava, eu já tava pensando em melhorar porque aquilo já não... já não tava me agradando, assim, mas mesmo assim, na convivência com os caras eu era de um jeito só que com o pensamento de outro, assim, eu era de um jeito que era aquele cara marrudão, meio bravo, mente psicopata, assim (rsss) pra que.... a convivência fosse melhor com, com os outros, assim...mas minha consc... mas meus pensamentos não falava pra ninguém, mas era de melhoria. Eu acho que todos têm esse pensamento de melhorar quando sair, mas nunca conseguem... dificilmente.... é.... e nesse dia a gente tomou uma ducha que era de, que era de mangueira de extintores, sabe? De bombeiro, água gelada meu! E a corrente da água muito forte, nossa! minhas costas ficou toda vermelha porque a gente agachou, ficou de.... é ... a gente ficou de.... de... como é que é? Assim, e com a mão na cabeça...

$\mathrm{V}$. Tipo canguru, que a gente fala?

A. Ficou de cócoras, canguru, é cócoras, com a mão sobre a cabeça assim ó (gesto) por baixo do joelho assim e... a gente ficou por três horas mais ou menos, não podia se mexer... se mexesse, a gente tomava...banho ... a gente já tinha tomado esse banho gelado de... essa mangueira e não estava calor, estava frio...

V. Você estava falando que nessa época você já pensava em sair fora dessa vida?

A. Tinha.... Só que eu saí, eu saí da Raposo Tavares....

V. Livre?

A. Livre... , Liberdade Assistida, LA, a Liberdade Assistida, estava cumprindo direitinho... só que passado uns dois meses eu fui pro... eu fui pro meu primeiro assalto depois que eu tinha saído pra rua.... no primeiro assalto eu fui preso, depois que eu saí pra rua...

V. Tava sozinho ou com o mesmo grupo?

A. Não, o mesmo.... o mesmo grupo é, não, não era mais o mesmo grupo, só que eu tinha convivência com o mesmo grupo, só que nesse dia que eu fui assaltar, não era com o mesmo, com o mesmo grupo... e aí tinha o Al. e tinha um cara alto, que era de maior, com nós... esse alemãozinho ele chamava D., D. era meu parceiro assim de ... de assalto, de... de droga, de...conviver sempre junto assim, depois que eu saí, né? Foi... depois que eu saí da Febem, eu já conhecia ele de vista, mas a gente nunca tinha feito assalto junto e aí a gente foi pra esse assalto lá no Banco... no Itaú, uma saidinha.... bom.... é..... e.... esse cara de maior, ele entrou dentro do banco e aí a gente foi fazer o mesmo assalto e eu não tinha conseguido pegar o banco, que era o que eu queria, eu já tinha ido preso, só que quando eu saí eu não queria pegar banco nenhum, queria ficar só na saidinha que era mais adrenalina, não sei que... e aí eu 
tinha feito o segundo assalto, é ... esse primeiro assalto que aí eu fui preso e aí o D. foi pra saidinha comigo, é o que estava armado, tava com um.... ah, e eu tinha comprado... quando eu saí, eles me deram de presente, cê vê o presente que o crime dá, né? Me deram um.... um 38 que a gente chamava de.... de Buldoguinho, esse Buldoguinho é um 38 pequeno, cano curto e ele é... ele tinha o cabo emborrachado, nossa! A coisa mais linda, assim... era uma super bonita (rsss) era preto... e eu queria pintar ele de cromado assim... e eu levei ele pro assalto, eu levei ele pro assalto, era meu, eu tinha ganhado de presente quando eu saí....aí eu levei ele pro assalto, foi eu e o D. e esse cara, esse cara escalou uma mala, escalou uma mala de 2 mil e 500, que não era época de pagamento, essas coisas... mas ele escalou uma mala de 2 mil e 500 num banco Itaú, próximo a Estação Santa Cruz.... bom era um.... era um senhor.... acho que a única vez que eu assaltei uma mulher foi a primeira vez, que eu assaltei o mercado, o resto acho que foi tudo tiozinho....é... uns caras assim da.... de uns 23 , mas não senhor de idade, nem velhinho, nem mulher, nunca gostei, só... essa vez do mercado, foi a primeira vez, foi só moeda, né? (rsss), bom e aí eu.... a gente assaltou a vítima dentro de um bar e a vítima não queria dar o dinheiro, o tiozão não queria dar, não queria dar de nenhuma maneira.... e tava dentro do bolso, ela tinha colocado em dois bolsos, pôs um tanto num bolso e o outro no outro bolso. Só que quando ela chegou no bar ele entrou dentro do banheiro direto.... a gente tomou uma coca-cola esperando ele sair, quando ele saiu ele tomou, pediu uma cerveja, quando ele pediu uma cerveja pro dono do bar, a gente deu voz de assalto e aí o dono do bar é.... deitou no chão e tinha mais duas pessoas no bar também que ficou assustada e... colocou a mão na cabeça e... não lembro se só.... só levantou as mãos, mas a vítima falou que não ia dar o dinheiro... e aí o que que eu fiz, na revolta de que ela não dava o dinheiro, e meu, meu parceiro entre aspas, que... que tava ali comigo, que pegou... que queria também o dinheiro que tava na.... tava na fita, na missão, né? Como a gente dizia.... que tava no lugar comigo, ele não conseguia encontrar o dinheiro... só que ele tinha entrado dentro do banheiro, a vítima, e eu acho que colocou no... colocou por dentro da calça, né? Por dentro da cueca dele e aí ele procurando no bolso ele não conseguia, aí o cara falou que não tava com dinheiro, que não tava com dinheiro, nisso eu já... nessa hora eu me injuriei e o meu parceiro também, eu dei um soco na barriga do car., da vítima, eu dei duas coronhadas na cabeça e uma no nariz, nisso começou a escorrer sangue, começou a sangrar e o cara caiu no chão, na hora que o cara caiu no chão, aí ele pois.. é... bateu assim no saco do cara, o meu parceiro botou assim a mão por dentro da calça e pegou o, pegou o dinheiro, pegou um ... um bolo de dinheiro - assim mais ou menos, dessa altura assim (fazia o gesto) - tinha 50, 100 reais embolado num elástico, aí o cara tava com 50 reais só no bolso de trás, que era, eu acho que pra pagar a cerveja... pra trocar esse dinheiro ... e aí nesse dia... eu acho que tinha.... eu não sei como, mas tinha um posto de gasolina do lado de uma avenida grande, eu não sei qual era aquela avenida, não sei mesmo.... do nada, a gente correu, correu, correu tanto e eu acho que era esses policiais que era esses mão branca ... eles tavam no rádio já... acho que se comunicando com a polícia e a... a gente já tinha visto uma viatura é.... vindo atrás da gente, mas no desespero, não sei se era atrás da gente, sei que ela virou numa outra rua que a gente ficou despreocupado, só que a gente se separou, ele entrou dentro de uma casa, isso depois ele me disse, né? Ele entrou dentro de uma casa e ficou escondido dentro do tanque, eu não, eu continuei correndo, continuei correndo e aí fui.... fui parar.... acho que já tava lá na região do Paraíso, já, de tanto eu correr eu já tava na região do Paraíso, só que eu não sabia qual rua ou qual o acesso que era pra mim, só que eu tava armado e 
... eu não queria jogar fora aquela arma, que meu parceiro já tava com o dinheiro, eu era de menor, qualquer coisa... eu depois pegava o dinheiro, né? Porque era sempre assim, eles guardavam o dinheiro até chegar, até sair de novo, ou eles davam pra família, né? E aí eu..... eu fui preso nesse dia... quando eu tava correndo, correndo e eu tava armado, e eu tinha... bala na arma, só que eu.... eu não atirei pra cima dos policiais, só que eu vendo os policiais vindo atrás de mim e peguei a arma e joguei num mato, tinha uns pés de bananeira, que depois eles entraram e acharam o revólver e aí... eu fui preso, chegando na delegacia, no $5^{\circ}$ DP lá no Paraíso, $5^{\circ} \mathrm{DP}$, fica perto... em frente ao Hospital do Câncer, não sei .... $5^{\circ} \mathrm{DP}$, mas fica em frente ao Hospital do Câncer, perto do Servidor Público... não sei se é na região do Paraíso, por lá perto, então... aí eu fui preso lá, aí fizeram a mesma coisa que.... apanhei de novo, mas tomei muito tapa na cara, muito, muito mesmo, que era de mão aberta assim e tinha um policial que, que falava assim pra mim que.... que quando eu saísse, que ele ia me matar porque... eu era um ladrão pé de chinelo, que não precisava eu ter batido tanto na vítima, e a vítima foi parar no hospital também, só que pra... pra reconhecimento a vítima precisava estar lá... isso já era de noite, não... eu tava dentro da viatura, chega uma outra viatura, quem tava lá, o D., o D. que era o meu parceiro, o D. tava lá na outra.... já passou muito tempo?

V.Passou uma hora.

A. Nossa, é mesmo? Tá bom.... Aí no, o meu parceiro o D., estava vindo na outra viatura e os policiais já escalou que ele, que ele já tinha caguetado, que eu tava junto com ele, não sei que lá.. aí eu... eu já sabia como, eu já sabia mais ou menos como era a coisa, já tinha passado pela Febem, já tinha passado por isso.. e ele também, o D. já tinha 4 passagens, já tinha passado pela Semiliberdade, já tinha ido preso, já tinha não sei que, e aí eu falei: não conheço esse cara, não tava comigo, não sei de onde que ele vem, não sei da onde ele é, não conheço de nenhum lugar e o D. falou a mesma coisa pro policial, depois os polícia, os polícias, não acreditando, deixaram a gente junto... numa... num corró, a gente chamava...., era um quartinho assim, tinha uma grade, aí deixou só nós dois lá e aí a gente começou a conversar... eu falei: oh D. o policial falou que cê... que cê tinha falado pra ele que... que eu tava junto com você, que não sei que... falei que não conhecia você não, aí ele falou a mesma coisa, falou "não, o policial veio com a mesma idéia, com a mesma conversa, falando que você já tinha caguetado" só que eu não falei nada disso e aí eu falei pra ele, oh, você é de menor certo, nós tava no mesmo assalto e então eu vou falar que você não tava junto e eu vou, pode deixar que eu seguro o refrão e ele era de menor também, pode deixar que eu seguro o BO porque a peça, a... o revólver tava comigo e eu já falei que tinha assaltado, que era eu que tinha batido na vítima, não sei que, então você pode ficar tranqüilo, mas se a vítima reconhecer você aí que... aí eu não posso fazer mais nada, né? Ele falou assim "não A., não B. (B. era o meu apelido) bom eu vou... não esquenta que quando você for... se você for preso eu vou junto com você e se você falar que a gente tava junto eu vou confirmar que a gente tava junto, se você falar que a gente não tava junto eu vou falar que a gente não tava junto", aí chegou no juiz, no delegado também, eu falei pra ele que a peça era minha que eu tava junto com o cara, mas ele só tava lá pra recolher o dinheiro e a gente tinha... a gente não tinha combinado nada disso, a gente se encontrou e tava vindo pro assalto sozinho, tal... e a gente se encontrou lá em Itaquera, que era um ponto de referência também e aí eu fui... ia vim pro assalto sozinho e encontrei ele e queria vim junto comigo e eu não ia deixar, mas a gente acabou vindo junto...

V. E aí foi os dois pra Febem? 
A. Aí foi os dois pra Febem e foi a mesma história do revólver, eu falei que tinha comprado o revólver na feira do rolo e aí ele viu a minha primeira passagem e falou "cara, cê tá contando a mesma história!" (rsss) Nossa mano, mas tudo bem! Aí ele falou "agora... agora cê vai pro..." aí ele me deu, é...ele me deu o cumprimento de 3 meses de relatório, né? A cada 3 meses era relatório, como que é? Cumprimento tri, trimestral, trimestral, tipo assim, a cada 3 meses ia o meu relatório pra mão do promotor... correge... corregedoria, não, é....promotoria da... da Vara da Infância e da Juventude e aí ia pro juiz, chegava na mão do juiz, o juiz avaliava se eu podia sair ou não pelo bom comportamento, mas eu saí com.... não, na primeira passagem eu fiquei 9 meses, né? Na Raposo Tavares

V. E essa segunda?

A. Na segunda eu fiquei.... 11 meses, 11 meses e 12 dias...

V. Aonde?

A. Eu fiquei em Franco da Rocha, fiquei em Franco da Rocha, fui preso no dia 13 de dezembro e saí no dia.... ah eu não lembro se foi agosto ou outubro que eu saí....

V. Foi nessa época que você foi pro Novolhar, não foi nessa época?

A. É... nessa época eu fui pro Novolhar... que já tinha um curso na....

V. É, já tinha um curso dentro da Febem....

A. Já tinha um curso dentro da Febem, aí eu fui pra Novolhar...

V. Me diz uma coisa A., o que você acha que leva esse povo todo a cometer infração, aí.. a entrar nessa vida?

A. Pra ser sincero.... eu.... eu fui... porque.... eu vi aquela revolta dos meus pais e assim, de uma certa maneira quando eles se separaram, meu pai não ganhava tanto pra, pra sustentar e aí começou a atrasar algumas coisas e aí eu queria ajudar de alguma forma, mas eu não conseguia trabalho, né? Eu não sabia por onde procurar um trabalho, não tinha um conhecimento...não tinha alguém que chegasse pra mim "oh, é... tem um trabalho aqui, vai lá, procura, e aí tinha uns meios mais fáceis, assim, que eu já conhecia, eu acho que é por isso, mas é... o que leva, o que leva mesmo, eu acho que é a convivência, a necessidade, dependendo da pessoa e..... eu acho que é isso, a convivência e a necessidade e a vontade de.... de assim, de ganância de ter o seu próprio dinheiro, assim, de ver algumas pessoas com carro, moto, com dinheiro fácil.... e você ter aquela ganância de, de ter pra você....

V. De ter coisas?

A. De ter coisas, essas coisas, da maneira mais fácil possível, mas... depois você cresce, amadurece, sabe... sabe que não é dessa maneira. Bom aí eu fui pra Franco da Rocha... fiquei lá 11 meses... passei pela UE 30, não sei se é UE ou UI lá, acho que é Unidade de Internação...., acho que só Unidade de Internação, eu fui pra UI 31, UI 30 e depois eu fui pro Internato, lá em Franco da Rocha, é Franco, Francão e Franquinho, passei pelos três, aí... e o juiz, esqueci uma coisa, o juiz, né? Falou assim pra mim, não o juiz não, minto, quando eu fui pra UAI, depois que eu passei pelo juiz, quando eu fui de Bonde pra Franco da Rocha, um cara, um negão fortão que era da... do SOS Criança..... que era sempre o mesmo, de óculos, negão, fortão, gordão assim, meu, forte! Ele falou assim "é, agora você vai var o que é, o que que é o inferno, você vai lá pra Franco da Rocha", eu falei: o inferno eu já sei onde que tá, aí... aí ele ainda falou assim "você ainda responde!" e me deu um tapão na minha cabeça, eles chamavam de... a esqueci como que eles chamavam esse tapão que era...., peteleco, sei lá o que que era....(rsss) não lembro mais ... faz tanto tempo, mas eu fui lá pra Franco da Rocha e fiquei lá... fiquei tranqüilo lá, passei por umas rebeliões... a primeira rebelião, logo quando eu cheguei era, era de um cara e ele 
era... tinha o seguro, né? Na... numa ala lá específica e aí os caras.. eu tinha acabado de chegar, né? E aí os caras... na rebelião os caras pegaram esse cara.. que ele era... ele era estrupador e... tava no seguro e quando virou a casa, que era a rebelião, né, quando o motim aconteceu, aí os caras pegaram ele, colocaram em cima de um colchão assim ó e pegaram, a gente chamava de Highlander, que era umas naifas, que eram uns, umas barras de ferro, que a gente apontava no chão mesmo e aí virava uma lança, com a ponta de lança e atravessou no coração do cara de uma tal maneira... que aí eles fizeram... meio que uma churrasqueira com carne do cara, que botaram de atravessado ele, ele assim é... na Highlander, na... nessa barra de ferro, colocaram entre as grades... uma grade e outra grade de um portão aberto assim, era um portão aberto e um fechado, colocaram entre ele, colocaram o colchão embaixo, tacaram fogo nele, deixaram ele queimar e aí arrancaram o pescoço, arrancaram o pescoço dele com....acho que era um... um... facão bem afiado, só que era também de barra de ferro, só que era aquela barra de ferro mais... mais fina e aí afiava, né, e arrancaram o pescoço dele assim e ele ficou com a cabeça assim e jorrando sangue, já tava morto... já tava morto e aí ele começou a queimar, queimar e aí depois é.... pegaram o corpo dele e queimaram e jogaram pra Choque, e jogaram pros funcionários lá, nisso tinha um monte de refém lá que era os funcionários e tinha os Seguro que era refém também nosso.....bom, mas isso foi só... algum, algumas coisas que ficaram assim na cabeça, é marcado, gravado que assim é... não... é inesquecível, mas tem outras coisas também que eu passei muito, que eram também piores....

V. Tem lembrança boa?

A. A lembrança boa é que você cria uma... uma amizade, que você não cria na rua assim, que é a amizade de união de.. de onde vai um vai todos... se acontece uma coisa, apanha todos, se apanha um apanha todos, sabe, assim? E aí você... cria uma amizade de lá fora você ter a mesma amizade de é..... uma amizade, uma amizade super sincera assim, mas sincera até o ponto que você não, que você não deixe falha nenhuma com nenhum... é... não deixe nenhuma falha, nem um pé sequer... nenhum.... rastro, assim... você vai ser bem conceituado, bem considerado e vai ter uma amizade sincera, mas se não acontece isso, você é traído de a ponte de... as próprias... o próprio convívio que as próprias pessoas chegarem a matar você...

V. Daí tem uma lei rígida que você tem que seguir?

A. A lei é você nunca falhar no crime.... é, quer dizer, nunca falhar com o seu... por exemplo, se você vai num assalto e cagueta, já é uma falha, se você vai num assalto e vai preso e o pessoal que tá na rua não ajudar a sua família, não... não seguir à risca com você... não chegar junto com você, que é o que diz, né? Você também já tá deixando falha no crime e aí você não é conceituado, não é bem visto, né? E aí isso vai acumulando na... na mente das pessoas e quando você dá... chega um ponto que você dá uma falha, os caras já falam todas as falhas anteriormente que você já deu e aí acrescenta mais essa e aí você acaba morrendo ou.... sendo espancado, ou... sei lá... V. E me diz uma coisa, tem lei fora do crime?

A. ...... lei fora do crime....

V. Lei ou essa coisa dessa amizade que você falou tão forte, tem isso nesse mundo diferente do mundo do crime?

A. Tem.... tem......Tem porque o crime ele é....dizem que o crime é.....não admite falha, só que o crime já é falho, o crime já é falho por isso, porque mesmo você achando que a vi., a amizade é verdadeira, entre aspas a amizade é sincera, né? Quis dizer isso... é...pelo fato de você falhar eles acabarem com sua vida e então... a amizade mais sincera, que eram... eram com as pessoas que cresceram junto comigo, 
aqueles que... os primeiros... que até hoje assim, a gente troca telefone, tem um contato, e são as pessoas que não entraram no crime junto comigo, mas eles sabem da minha vida e mesmo assim não foram ... pode não.. é... abandonado entre aspas, é.. eu digo assim, por exemplo no dia é.. quando eu tava preso eles mandavam um abraço e tal, mas o que eu queria era ... era por exemplo, um pacote de bolacha, mas eu sei que não era eles que tinham que tá ali comigo, chegando junto comigo e com a minha família, disso eu sei, então mas é... essas são as amizades mais verdadeiras que eu digo hoje que é, são meus amigos, que eram as pessoas que ia.. que foram criados junto comigo, que são até hoje, até hoje uns faz faculdade, uns são ... trabalham, uns já tão casados, estudam, ou faz qualquer coisa, mas não entraram no crime junto comigo e .... assim.... eles têm uma mente diferente, que a conversa é diferente, você dá risada, sem ter a mente maléfica de..... de qualquer coisa já ter maldade, já querer atirar, já querer matar, já querer assaltar, se falta dinheiro já assalta, não, os caras mesmo estando desempregados os caras tem a vida deles e convive com isso muito bem, que por mais que estejam passando por um processo de problemas, é... eles sabem como se, como lidar isso, lidar com essa situação, acho que essas são, acho não, tenho certeza que são as amizades verdadeiras que estão, que duram e que estão durando e... devem durar pra sempre, assim.... Bom, depois que eu saí de Franco da Rocha... eu... completei meus 18 anos, é saí em Outubro, saí em outubro e completei 18 anos dia 21 de novembro, minha idade ah... meu aniversário dia 21 de novembro; ah e fora que eu passei aniversário, passei natal, passei o ano novo, carnaval, todas as festividades, dias das mães, dias dos pais, isso era sempre o que me chocava assim, que era, como a gente dizia lá dentro, que era o que pesava a cadeia, era o que pesava a mente assim, que era esses dias de festividade que você não podia estar com a família, mas tinha os momentos bons que eram os dias de confraternização, os melhores momentos era o que era, o que tava com a família sempre junto, acho que isso eu vou ter na minha mente também e não quis isso mais pra mim, quando eu saí eu... fora que minha mãe teve.. eu falei que no $5^{\circ}$ DP ela ficou internada num... então, ela ficou internada no Hospital do Câncer depois, ela ficou internada 2 vezes, na primeira vez e na segunda vez ela ficou internada no Hospital do Câncer, é... com o mesmo problema que era de AVC... minha mãe teve dois AVCs e no decorrer da minha... da minha tirada de cadeia que era... no meu tempo na Febem ela teve AVC, teve também por causa da rebelião que mostrava o negócio, tal e aí ela teve esse AVC de novo, aí eu criei na minha conscientização que eu já tava matando minha mãe aos poucos, meu e isso pra mim já estava me corroendo e que se eu perdesse minha mãe era a única coisa que eu tinha na vida, porque meu pai não... não me deu tanta atenção assim quanto minha mãe, na base só me criticava, não me deu tanta atenção assim como minha mãe, então... a minha mãe era a única pessoa que eu podia contar nessa, naquele momento, fora minha irmã e meu irmão, né? Mas se eu perdesse minha mãe eu ia me sentir culpado até ... até o final da minha vida.. porque era a pessoa que estava ali junto comigo e eu estava matando aos poucos, sem.... mérito nenhum, sem.... escrúpulo nenhum, vamos dizer assim... E aí isso foi martelando minha mente e... eu acho que foi o que ajudou também eu a ... a mudar de vida... e aí surge a Novolhar, a Novolhar foi, tem.. foi a ONG que... que me direcionou quando eu saí.... o Paulo Santiago, ele me ligou, que é o... acho que é o coordenador da Novolhar, coordenador da Novolhar até hoje e aí ele me ligou e falando, e eu já tinha feito o curso lá em Franco da Rocha, já tinha terminado, já tinha ganhado até diploma lá, tenho até a foto....

V. Eu fui nessa festa, eu lembro, foi quando eu te conheci... 
A. Se foi né Vanessa, eu lembro... foi, foi super legal, eu gostei do curso, e aí quando eu saí, eu já queria parar assim, mas.... eu não tinha uma direção assim... eu não sabia por onde começar... e eu acho que foi a Novolhar que me deu a direção, assim, de um curso, de saber que tem... tem caminhos, de saber que tem oportunidades também... que não é só... é.... tipo....que não era só aquela vida que eu tava vendo que existia, tinha outras à minha volta, tinha outros mundos, tinha outros, outras, outras convivências.... e aí ele me chamou pra saber se eu queria fazer, se eu queria continuar o curso, né? E aí fiz, acho que eu fiz uns 2 anos de curso (rss), cada 6 meses eu me... eu concluía o curso e já fazia outro e já fazia outro, acho que isso foi uns 2, 3 anos, não, acho que uns 2 anos só fazendo curso, acho que eu fiz uns 4 cursos de... de vídeo produção, devo ter um monte de certificado, mas esse era legal, era legal porque tinha... tinha as pessoas que estavam dentro da Novolhar, que davam essa esperança de.... de um mundo... de um mundo bom, diferente do que era........ Bom e aí eu consegui um estágio que era no.... através da Novolhar eu consegui um estágio que era na... no Museu da Pessoa, no Museu da Pessoa, trabalhei por 1 ano e 2 meses, como estagiário, só que remunerado, né? Ganhava, meio período, eu ganhava e ... era na área de vídeo, assim, de assistente de cenografia embora já... já tava operando câmera, bom e aí eu saí do Museu da Pessoa, saí depois que acabou o estágio, eles me seguraram mais um tempo, mas acabou o..... é......acabou os... caramba esqueci... os contratos com a Petrobrás... acabou a grana.... que era o que sustentava o Museu da Pessoa, que era onde entrava o dinheiro e aí as pessoas foram embora, inclusive eu... os funcionários, vários funcionários na verdade, o Museu da Pessoa era grande pra caramba em termos de funcionários, bom e aí eu, através da Novolhar também eu dei uma entrevista que foi para o programa Filhos na STV, na... Rede Sesc Senac de Televisão e aí eu acho que contei praticamente, eu contei essa história mais ou menos e aí eles me deram uma bolsa com o equivalente, acho que era de 3000 reais, do curso de operador de câmera...

V. Você foi fazer?

A. Eu.... eu fiz a prova, só que eu não passei e aí o que que eles fizeram? Como eu não passei, eles me deram outra bolsa, que era de Oficina de Vídeo. Eu fiz o Oficina de Vídeo, prestei a prova de novo, passei, aí a única coisa que eu paguei, foi 20 reais que era da...da inscrição e pra você fazer o teste, né? Da prova... passei no teste e aí eu fiz o Operador de Câmera... Fiz o Operador de Câmera, mas assim... ainda não peguei o certificado ainda, já faz acho que 1 ano que eu terminei, 1 ano não, minto, acho que até mais... já tô na.... na TV P. já há 1 ano e 4 meses, mais ou menos, que foi em fevereiro que eu entrei.... estamos em?

V. Novembro, quase novembro, último dia de outubro.

A. Nossa! Então eu tô 1 ano e...1 ano e meio, praticamente, mais ou menos ou até mais. Bom e aí eu fiz o Operador de Câmera, mas eu não dei entrada na DRT, no DRT, que é Diretoria Regional do Trabalho, e aí eu fiz um freela, tava na... na....eu tava fazendo o curso e algumas... eu tava na... fazendo alguns projetos com a Novolhar de gravação.... e aí eu até recebi um salário... e aí eu fiz um freela pra TV P., de operador de câmera, os caras gostaram do meu trabalho e aí depois de uns 2 meses, assim, que eu já tinha feito o freela, eles me chamaram pra... pra...pra poder ter um contrato de ... de trabalhar com eles, é....não fixo com registro, assim, que ainda hoje eu não tenho registro, mas futuramente, provavelmente vamos, vou ter o registro, ainda bem, né? Tava demorando rsss...

V. Você voltou a estudar A.?

A. Voltei, terminei, terminei os estudos, terminei o terceiro... 
V. Terminou o terceiro, aí fez o curso de câmera....

A. Mas eu terminei o terceiro, ó... eu passei no chute na sétima, passei no chute na oitava, passei no chute no primeiro, estudei na Febem, estudei na Febem, tinha escola lá, tinha uns cursos profissionalizantes, mas o... o certificado que davam era... por exemplo é.... certificamos que A. é... teve.... concluiu o curso no Complexo Franco da Rocha, sabe assim? Como cê vai apresentar uma coisa que .... porque é um passado, assim, não é inesquecível, mas é um passado, assim, que você, que pra algumas, algumas pessoas, que pra alguns lugares você não tem que dizer e... falar que você passou pela Febem, não sei o que.... e aí era ruim... era ruim...eu recebia os certificados e falava pra minha mãe rasgar, acho que era só... tinha um curso de fotografia, um curso de vídeo, assim, que era da Novolhar que dava o certificado bonitinho assim, mas o de dentro do Complexo era .... Complexo Franco da Rocha, horrível.. era coisa estranha, então, o terceiro colegial eu terminei no chute também porque eu tive uma internação, eu fiquei, aí.... eu tava concluindo o terceiro colegial fiquei doente, eu tive problema na vesícula, tive problema na vesícula que tem, acho que é, tem um cordão, como se fosse um cordão que tem... o trabalho de... de jogar o açúcar pra, pro pâncreas, um negócio assim, eu não sei explicar direito, mas isso entupiu, na hora que entupiu, inflamou o pâncreas, eu tava com pedra na vesícula, só que eu não podia operar da pedra na vesícula porque o pâncreas estava inflamado e... aí... quando eu ia pra mesa de cirurgia, que os caras iam me abrir, eles resolveram fazer uma tomografia antes e viram que meu pâncreas tava inflamado e aí não... eu não consegui, eu não consegui operar porque senão ia morrer na mesa de cirurgia, bom aí o pâncreas eu tinha que esperar... esses três meses, esses dias que eu fiquei eu tive que esperar o pâncreas desinflamar, só que o pâncreas não desinflamou, ele criou um pseudo-cisto que era uma bolha de trás do pâncreas e aí eu tive que esperar essa bolha amadurecer, ou ela estourar e desaparecer, ou ela é... diminuir e desaparecer, ou ela estourar e meio que sair por meio que de fezes ou de.. furúnculo assim, sabe? Na pele... de algum jeito ia sair esse líquido e esse líquido era inflamado, se a bolha estourasse no meio da cirurgia eu morria, eu ia morrer, pegava uma infecção e era... muito ruim. Bom nesses 3 meses, fora a vesícula, o pâncreas, a pancreatite e o pseudo-cisto, eu tive derrame pleural no pulmão, que eu não conseguia respirar, tive uma alergia que eu fiquei roxo do joelho até o pé e dos dedos até o ombro aqui ó, tudo roxo, que eram umas bolinhas e começaram a ficar umas manchas e aí eu fiquei todo roxo, não conseguia andar, não conseguia andar, entrei em depressão, ficava com febre acho que praticamente quase todos os dias desses 3 meses fiquei com febre, fiquei com, de jejum 27 dias, perdi 18 quilos e me alimentava por uma bolsa que não lembro como que chamava, mas era pelo pescoço, está vendo essa mancha aqui no meu pescoço? E essa outra aqui ó? E essa outra aqui é? Tá vendo? Então era... uma espécie de um leite branco que eu não lembro como era, essa bolsa, não lembro como que era o nome dela.... Eu sentia muita fome, muita fome, muita, muita fome, sede, eu não podia beber água, porque senão, se trabalhasse meus órgãos, meu organismo se eles, se os meus órgãos começassem a trabalhar, triturar alimento, essas coisas eu ia sentir dor, então... entrava direto pelo pescoço que é uma veia mais grossa que a gente tem e aí eles me furavam, davam anestesia e me furavam e aí eu... e aí entrava uma espécie de um caninho.... que aí eu me alimentava, só que fedia tanto, que minhas fezes era tão fedida, bom, mas não vamos falar disso não! (Rsss) Esse é um assunto ruim (rsss)

V. Mas aí você falou que ficou doente quando estava fazendo a escola... 
A. Estava fazendo a escola e aí eu... acabando... eu terminando isso eu levei um atestado, levei o atestado médico, o parecer do médico de que que eu tinha, e eu fazia, eu fiz alguns trabalhos dentro do hospital eu tive é... por mais que eu estava muito doente eu consegui... eu fiz uns trabalhos assim bem... bem fracos assim, mas eu consegui fazer eles e aí também minha irmã me ajudou a fazer alguns trabalhos, mas aí eu consegui passar meio que no chute assim porque eu, nesses três meses eu levei atestado e passei por... pelo atestado assim...

V. Isso foi o ano passado?

A. Isso foi o ano passado... eu fui internado 12 de.... outubro também na minha vida! Nossa! 12 de outubro, foi dia das crianças, né? Então foi no dia das crianças que eu fui pro... eu pro hospital do Emílio Ribas, aí eu fiquei 2 dias no Emílio Ribas, o pessoal não sabia o que que eu tinha e mandaram eu urgente, urgentemente para o Mandaqui, é um hospital de Santana, aí eu fui pro Mandaqui e lá fiquei... fiquei lá 3 meses, aí ganhei uma cicatriz na barriga... uma cicatriz na barriga, tiraram minha vesícula e agora eu estou bem melhor, minha barriga parece que está adormecida...

V. Agora vida normal?

A. Vida normal agora, só não carrego tanto peso porque parece que eu estou fraco agora, não consigo mais... até voltar... É isso... aí estou na TV P., provavelmente vou... é...provavelmente vou ganhar um registro, bom e estou fazendo aquilo que eu gosto, que é mexer com vídeo... e a bolsa que eu ganhei, eu falei que queria ser cinegrafista, né? Então eles me deram, por isso que eles me deram a bolsa, o curso de cinegrafista de graça, gratuito, a bolsa integral, pelo Senac e tudo mais...

V. E você tem o DRT?

A. Não, por isso eu não peguei o certificado, eles mandaram até um telegrama pra ir buscar o certificado, porque demora, né? Depois que você conclui o curso, demora uns 3 meses pra sair o certificado. Só que aí com os meus problemas eu não fui buscar ainda, mas eu agora não fui buscar de preguiçoso, viu Vanessa? Mas eu vou buscar sim. É isso...

V. E a relação com a sua mãe como é que ficou?

A. Nossa, minha mãe agora, ela tá super feliz, ela tem uns problemas de pressão, tal, mas eu cuido super bem dela e minha mãe (rss) minha mãe é maravilhosa! Minha mãe é super boa, assim, e agora está.. Ah e eu não falei que vou casar, né? Agora eu vou casar, minha.. minha futura esposa, a A. C., C., ela está grávida de 1 mês e aí eu acho que o nome do... se for menino acho que vai ser Eduardo Henrique... Eduardo Henrique, ela queria só Eduardo, mas eu falei põe Eduardo Henrique, dois nomes né? Bom... é isso, tô feliz.. Ah eu vou... te convidar e o pessoal do Novolhar também para o nosso casamento... Então, mas é isso, mas a convivência com a minha mãe está super bem, super boa, assim, ela está super feliz, super feliz, ela fala de mim, assim, pra qualquer pessoa com muito orgulho de..., mas ela não fala que eu já passei pela Febem, essas coisas, mas ela fala com muito orgulho que.. que é eu que cuido dela porque meus irmão estão casados...

V. E quando você casar?

A. Nossa, quando eu casar acho que ela vai ficar super triste.... mas acho que... que eu vou levar ela comigo... ela adora minha namorada também, elas se dão super bem... é isso, minha vida, minha vida continua, minha vida está mil, minha vida está $100 \%, 1000$ maravilhas... Eu acho que meu sonho, meu sonho já está realizado, que é vê minha mãe assim com um sorriso assim, por mais que ela esteja um pouco doente, algumas coisas, ela está até afastada do serviço, mas eu tô feliz porque ela está com 
um sorriso melhor, uma feição melhor e sabe que... minha convivência é outra, meus amigos são outros...

V. Aquela turma você nunca mais viu?

A. Eu vejo, eu vejo, mas é... cumprimentar, falar oi e está tudo bem? Como que está? Pronto, mas não fico de rolê, não saio, a minha convivência maior é com o pessoal lá da Cidade Tiradentes que é lá na minha rua, são meus amigos, trabalham também e a gente sai junto tal, sai com a namorada deles, a gente sai junto eu, minha namorada e a namorada deles e eles, sai em festa, curte, nossa! Totalmente diferente... e a convivência no meu serviço também que tem uma amizade super boa.... acho que é isso...

V. É isso?

A. Acho que é isso...

V. Quer falar mais alguma coisa?

A. Acho que não tem nada não.... não que eu lembre, não mas, se de repente surgir mais alguma coisa eu falo pra você... eu gravo e mando....eu te mando por e-mail... então é isso, Vanessa.

V. Valeu, A., eu estou super feliz! Você está atrasadésimo, né?

A. Tudo bem, o pessoal entende.... 
Transcrição entrevista Breno

24 anos

Entrevista Concedida dia 29/03/2007 nas dependências da Associação Novolhar.

V. Gravando.... Vou deixar aqui pra captar bem a sua voz....

B. Certo.

V. Queria que você me contasse um pouco sobre a sua vida, onde você nasceu, o que você fazia, quantos anos você estudou... enfim, conta um pouquinho pra mim...

B. Ah então... eu tô aí no devagar e sempre, né? Como foi assim que eu aprendi, e.... eu acho que, acho não, penso que eu estudei até o que eu pude assim, não tive muita... quer dizer até pude terminar, mas quando a gente é criança a gente não ouve muito as pessoas e também acho que a gente... não pegava muito no pé assim, né? As pessoas têm que pegar um pouquinho no pé pras pessoas, mas é isso aí, eu tô... eu nasci, pelo menos me disseram aqui em São Paulo, eu sou paulistano, ããããã.... estudei até a .... oitava série e tô aí.... passei muito pela rua....

V. Morou na rua?

B. Morei na rua, é..... que mais..... morei na casa de menor na Djalma Dutra...

V. Aqui perto?

B. Não... pelo contrário, é longe, é lá na Luz.... Mas e aí continua....

V. Então, como que era sua relação.... quando você era pequeno, você nasceu e morava com a sua mãe?

B. Provavelmente....

V. Você nem lembra?

B. (fazendo gesto) aqui.....

V. Tem irmãos, não?

B. Devo ter, alguns.... minha mãe era prostituta.

V. Não teve muito contato com ela?

B. Tive, acho que o suficiente, por isso que ela me deixou.

V. Tá, aí você foi pra essa casa?

B. Não, morei na rua depois que eu fui pra casa....

V. Quando você ficava na rua você ficava onde?

B. Vários lugares, nunca tem um lugar.

V. Como que você conheceu o Novolhar, como que você entrou em contato com o Novolhar?

B. Vieram atrás de mim na verdade, falaram pra eu que eu tinha que ir lá e eu fui e eu tô aí...

V. Quem que falaram?

B. Ah depois você procura, você é pesquisadora, pesquisa!

V. Ah é? (risos)

B. É lógico, o seu trabalho é esse, pesquisar....

V. Sobre a sua vida?

B. Não sei se sobre a minha, sobre o que você quiser... minha vida não é a melhor de todas, eu não sou melhor que ninguém, eu sou um cara simples, humilde que tô aí devagar e sempre e quero vencer, entendeu?

V. A sua vida com certeza tem importância...

B. Se Deus quiser....

V. Com certeza tem e.... aí assim, quando a gente fala sobre a própria vida, claro que sem te identificar, não quero que ninguém... ah, é fulano que tava lá naquela tese, não 
sei que lá... é.... outras pessoas podem ler e podem aprender, porque eu acho que essa é a idéia de uma pesquisa, fazer com que os outros aprendam alguma coisa....

B. Bacana. Acho que você tem que viver pra você aprender, não adianta ficar só perguntando, né? Eu perguntei muito e teve pessoas que ficaram quietas, por isso que eu tô... meu eu tô aprendendo que tem que ficar quieto, só isso, ficar quieto..... Continua, desculpa...

V. Se falar... pode dar problema, é isso?

B. Poxa....

V. Você foi aprendendo isso na cacetada ao longo da vida....

B. É.... puts eu já fiz cada merda que se eu pudesse, tipo assim, pegar uma fita, sabe assim uma fita, como que nem eu aprendi aqui no Novolhar, se você for ver, vê a número 1 , a fita número 1 que você vai me ver....

V. A do Programa? A do Programa Novolhar número 1, é isso?

B. Isso....

V. Vou ver, vou ver....

B. Ã.... se eu pegasse essa fit... a fita da minha vida, apagaria várias partes de coisas que eu fiz assim que foi merda assim que tá aí pra gente aprender, né?

V. Com certeza, tudo que você fez, fez você pensar desse jeito que você está pensando, não é? Foram todas as experiências que você viveu que... enfim, que fez você pensar do jeito que está hoje.

B. Você está gravando mesmo? Acho que isso aí não grava não....

V. Grava sim.... tá, 4 minutos de gravação...

B. Pra mim não grava não, mas tudo bem, continua...

V. E..... que coisas são essas que você fez? Pode me contar alguma?

B. Não... aí são coisas minhas... eu não te conheço, não vou contar essas coisas, eu não sei nem porque que eu tô aqui falando pra você as coisas, eu sou um cara que..... acredita nas pessoas, entendeu?

V. Que bom que você ainda acredita nas pessoas, porque quando a gente perde isso a vida fica muito difícil, né?

B. Não sei, vamos saber, só daqui pra frente...

V. Acreditar nas pessoas é bacana...

V. Você quer parar B., por mim não tem problema. Eu quero que você se sinta à vontade.

B. Eu tô à vontade, tô tranqüilo, só que eu acho que não está gravando nada...

V. Tá sim, pode ver, está andando o tempo...

B. Não, não preciso ver, eu acredito na sua palavra, se você estiver mentindo você estará se enganando, não a mim....

V. Com certeza, mas está gravando sim.... A sua experiência de gravação é com imagem, né?

B. É..... sei lá, acho que com.... eu tenho um rádio de gravar, que nem está comigo, está na casa da minha pequena grande mulher que eu gosto, mas a gente se separou, infelizmente e eu gosto de gravar sim, todo mundo fala que eu tenho uma voz bacana, sei lá, eu sempre achei feia e gravei com... vídeo, sei lá, tô aí....

V. Você é câmera aqui no Novolhar?

B. Ah, não sei se eu sou câmera, sei lá....

V. Free Lancer?

B. Isso é.... free lancer....

V. Você faz algumas atividades aqui e em outros lugares também?

B. Também..... também..... é devagar e sempre a gente tá aí, né? 
V. Vai andando devagar...

B. É.

V. A sua experiência na escola, B. como foi?

B. Ah... foi bacana, me colocaram numa sala especial eu sendo normal.

V. Por que fizeram isso? Um psicólogo sem vergonha fez isso com você?

B. É, vai saber, vai na escola P.M. e pergunta.

V. Aí você ficou na sala especial?

B. Isso mesmo.

V. Muitos anos?

B. Não sei, o ano que eu estudei lá.

V. Você foi até a oitava série nessa escola?

B. Você vai pesquisar, pesquisa, já que você quer fazer uma tese, pesquisa por favor.

V. É, eu pesquiso, mas é que... assim, quando tem a ver com a sua vida eu prefiro ficar com aquilo que você quer me contar, não com coisas que eu possa encontrar...

B. Então, mas eu acabei de te falar que é melhor ficar quieto do que contar, entendeu? Então o que? Você que é a psicóloga, não é assim? Os psicólogos eles só ouvem, não falam nada.

V. Não, ele mais ouve do que fala, mas ele fala também.

B. Então, na... você sabe que na Grécia, ã.... na.... acho que você já deve ter lido, não preciso te falar mais nada, mas continua.

V. Não? Pode falar, eu não sei do que você está falando.

B. Não.... você estudou, eu não estudei, não sei do que você está falando, pô? Continua.

V. A gente aprende com as experiências da vida, não é só a escola que ensina pra gente.

B. É então, por exemplo a mocinha.... eu não sei, eu não lembro o nome dela agora, a...

V.A que está aqui?

B. É a produtora.

V. A M?

B. É a M, ela falou que é chefe agora! É....

(longo silêncio)

B. Prefiro não falar, só me pergunte e eu falo, vamos fazer assim, não é uma entrevista? Você pergunta e eu falo.

V. Eu pergunto e você responde.

B. Isso!

V. Eu pergunto e você responde, se você não quiser responder você fala assim, não quero falar.

B. Tá bom, firmão, é isso mesmo!

V. Então tá bom, então deixa eu ver... é, como o meu tema é adolescente que comete ato infracional eu queria sua opinião sobre o que leva um jovem a cometer uma infração. O que você acha que acontece?

B. Necessidade, eu acho que tudo a partir da necessidade, continua....

V. Necessidade de que? De dinheiro ou de outra coisa?

B. De tudo, necessidade de..., né?

V. No geral....

B. Você é muito mais inteligente do que eu penso.

V. É.... eu vou enumerar algumas necessidades, você fala pra mim se é isso, se é mais coisa ou se não é. 
B. Pode, pode enumerar...

V. É.... por exemplo, tem gente que me fala assim "eu queria ser considerado no meu bairro", ser considerado uma pessoa bacana, por isso eu cometi uma infração.

B. Entendeu.

V. Você acha que isso é uma razão suficientemente forte pra correr o risco de ir pra uma Febem...

B. Acho que cada um, cada um.

V. Pra você seria?

B. Cometer uma.... uma, pra ser respeitado?

V. É.

B. Não sei, só na hora.

V. Só na hora.... vai muito do momento?

B. Hum... também, é muitas coisas... muitas coisas, são muitos elementos.

V. Cita alguns pra mim?

B. Não preciso.

V. Por que não?

B. Porque você tem que viver pra você saber, não preciso te falar.

V. Você acha que eu preciso cometer uma infração, passar pela Febem, quer dizer agora no caso eu tenho mais de 18 anos, né? Passar por uma cadeia....

B. Você deve ter 30 mais ou menos.

V. Mais ou menos. Passar por uma cadeia pra só assim eu conseguir aprender?

B. (risos)

V. Alguma coisa sobre esse tema?

B. Você que está falando...

V. Não, estou te perguntando....

B. Eu não sei... não, eu faço tudo certo pra eu nem ir pra cadeia, porque eu já fui lá dentro da cadeia, eu conheci pessoas e as pessoas me falaram muitas coisas, ã... inclusive vi, é.... presenciei nos meus olhos a invasão do Carandiru quando eu era moleque, morava lá na Luz, não lembro nem a data, mas presenciei os caras entrando, cordão de gente, de família lá na frente, tomei um tapão no meio da cabeça....

V. De quem?

B. Dos... da cavalaria.... e é isso, lembro como se fosse hoje... hum, mas continua.

V. Você já ficou preso alguma vez?

B. Eu tive acho que... é... algumas passagens, eu dormi na 77 se eu não estou enganado, é que meu? Tanta coisa, muita informação, entendeu?

V. Sua vida tem muita informação....

B. Muita! Demais e eu não, tipo assim, eu não... eu não sou um cara da escrita, entendeu? Eu prefiro pensar, é falar... tipo cantar é sabe assim, dizer... e alguma pessoa... é por isso, é... a minha pequena grande mulher ela me deu esse rádio porque eu prefiro falar assim, manja? E aí eu não tenho muita pra pensar, se eu pensar eu não escrevo, então eu prefiro falar entendeu?

V. Você fala pro gravador e...

B. É e aí ele grava, ou senão sei lá, arrumar uma pessoa bacana que escreva seria legal.

V. Precisa falar pro gravador, passar pra alguém que você confia escrever, escrever um livro sobre a sua vida!

B. Seria bacana, vamos ver, não sei, só Deus sabe.

V. Você compõe rap ou algum tipo de música? 
B. Eu escrevo, escrevo bastante coisa, tenho muita coisa já escrita, inclusive essa se., nossa inclusive esses dias tá a milhão minha cabeça!

V. A cabeça tá a milhão?

B. Tá muito legal, assim!

V. Tá dando tempo de anotar, de falar no rádio?

B. Eu tô falando cara! Mas eu tô ficando quieto que eu tô aprendendo que o negócio é calar a boca!

V. É que quando você está falando pro rádio você está falando pra você mesmo, não é pra outra pessoa ouvir, né?

B. Ã... não sei....

V. Você tem a intenção que alguém ouça?

B. Não sei, acho que você nunca tá sozinho, né? Como a gente tá aqui, ó tem muita coisa, muita informação, a gente está aqui nós dois, mas ao mesmo tempo tem pessoas lá, tem pessoas aqui atrás, tem pessoas aqui e assim tá aí (risos). Tá na rua, você está sozinho, mas você não está. E aí?

V. Você fica ligado sempre no entorno?

B. Ligado no entorno?

V. É, quem tá à sua volta, o que está rolando, que está acontecendo?

B. Eu? Ah, não sei, só na hora pra gente saber. Você fica? Você está ligada?

V. Depende de onde eu tô andando. Se eu tô andando em algum lugar que eu considero tranqüilo eu não tô ligada, mas se eu estou andando na Praça da Sé, eu normalmente estou ligada.

B. A é? Eu tô.. tô na minha, porque assim, acho que você é o que você faz, entendeu? $\mathrm{O}$ que você pensa, é isso. Se você fizer o bem você terá o bem, se você fizer o mal você vai ter o mal, eu sei que o mundo é... foda, que nem outro dia tentaram me roubar ali, mas não conseguiram, entendeu? E é isso...

V. Você reagiu?

B. Não reagi não, só fui mais rápido (risos).

V. Saiu correndo?

B. Não, não saí correndo, eu.... sei lá parece que alguma coisa me avisou e eu na hora! A pessoa ficou quieta e saiu andando, entendeu? (risos) É melhor calar, é o que eu estou te falando, é melhor ficar quieto....

V. Do que sair falando... O que você gosta de fazer na vida?

B. Não tem o que eu gosto de fazer na vida....

V. Tem o que você não gosta?

B. É.... que eu não goste? Também.... acho que é tudo na hora, tudo ali, você vai saber, até coisa que eu não gostei e fiz, depois ...na hora que eu fiz, eu falei puta que merda! Que merda! Que merda! mas aí você vai e as coisas estão indo e... é uma fita, né malandro? O que foi gravado já foi gravado (risos) não dá pra voltar (risos) entendeu?

V. Entendi.

(silêncio)

V. E na Febem você chegou a passar?

B. Eu tive uma.... eu fui preso com um amigo, quer dizer, ele se dizia amigo, depois eu nunca mais eu vi também, inclusive a droga nem era minha, era dele, eu segurei, sou um cara muito bom sabe assim? Isso que é foda! Mas eu sou isso, sou esse cara, esse cara é o que eu sou, entendeu? É esse, vou ser sempre assim, pode fazer o que for, posso estar onde estiver eu vou ser esse, não tem essa.

V. E você tava com esse cara e foi pego? 
B. É.... eu fui pego aí.... inclusive eu trabalhava na Cosesp, ã.... eu tinha tíquetes no bolso, assim, a carcereira roubou meus tíquetes, tá ligado? O delegado falou que se eu pagasse pra ele, ele não faria nada e depois eu tive que comparecer... quer dizer, fui pra Febem, né? No caso, dormi acho que uns três dias... alguns dias assim... e como eu morava na Aclimação na Casa, na própria casa da Febem e eu estudava, trabalhava, eu sou um cara que eu devagar e sempre estou querendo fazer minha vida bem, entendeu? E.... e aí o juiz falou que eu poderia ir pela minha boa conduta, entendeu?

V. Tá, não pegou nenhuma medida socioeducativa então?

B. Eu peguei uma medida socioeducativa, aí fiz alguns dias e não fiz mais... (risos)

V. O que era, PSC? Aquela coisa de comparecer em algum....

B. Era...

V. Alguma instituição, o que era?

B. Ah, não, agora lembrei, eu acho que foi trocada, como eu trabalhava, eu trabalharia uma hora a mais, entendeu? Alguma coisa assim....

V. Ah tá....

B. Foi uma coisa assim, porque a COSESP tem um programa que é a capacitação de menores, né? Aí eu já estava nesse programa, aí já foi meio que...

V. Encaixou no seu horário a mais de trabalho e cumpriu ali a sua medida.

B. É, acho que foi isso, ou não, não lembro....

V. Você nem lembra....

B. É muita coisa né, cara? Eu até lembro, mas é muita coisa, continua....

V. Quantos anos você tinha nessa época?

B. Não lembro, dá uma pesquisada (risos)

V. Ah isso não vai dar....

B. Por que não, é só você ir lá, está tudo registrado, isso aí ninguém apaga, a não ser que os caras queimaram, senão tá tudo aí....

V. Eles devem guardar por alguns bons anos, não sei quantos, mas acho que não guarda pela vida toda não... Só a gente mesmo que guarda as nossas histórias, os outros não.... o que vira papel, o que vira fita acaba ... pode se perder eu acho, não sei.... se a gente pega uma fita de vídeo muito antiga ela embolora...

B. Isso mesmo.

V. Você perde o.... infelizmente você perde ... às vezes você quer rever alguma coisa e.... Sua memória acontece isso de vez em quando? Você quer relembrar alguma coisa e não vem?

B. ... A sua acontece?

V. A minha acontece.

B. Então você se responde....

V. Eu respondi por mim, queria saber por você...

B. Não, mas se você responde, a gente, nós somos seres humanos...

V. E somos diferentes....

B. Então, mas somos seres humanos, simplesmente ser humano... sim? Continua.

V. Ser humano simples?

B. É...

V. Puxa vida, você acha mesmo que o ser humano é um ser simples?

B. Eu tenho um ditado que diz assim: quem acha perde, entendeu? Tudo aconteceu porque eu achei uma coisa, e trouxe coisas boas, depois perdi uma coisa que eu gostava muito, mas eu tô vendo que eu tenho que achar também...

$\mathrm{V}$. Tem que continuar procurando pra achar... 
B. Não, não é só procurando, achar! Porque você procura, você consegue, né? Se você acha, você não está procurando, você achou, mas pensar é bom.

V. Pensar faz bem?

B. Eu acho....

V. Depois você fala o que você pensa, ou não?

B. ... Você fala?

V. .... Nem sempre.

B. Então (risos) continua...

V. Continua você.....

B. Ah, você me respondeu, você é um ser humano, só somos do sexo oposto.... e é isso. A fonte, né? A coisa mais primordial, sem minimidades, mas e aí?

V. Hum.... deixa eu ver que mais..... Ah eu estava tentando saber o que você pensa do que leva uma pessoa a cometer uma infração, alguma coisa... você acha que as amizades influenciam?

B. Você acha que sim?

V. Eu não queria saber o que eu penso, queria....

B. Mas você acha?

V.... o que você pensa? Vai te ajudar eu responder?

B. Claro, lógico.

V. Por que?

B. Porque você é estudada e eu não.

V. E você tem a experiência vivida e eu não.

B. Então, por isso que eu estou te perguntando, me fala, o que é?

V. Será que a gente pensa a mesma coisa? Um tendo só lido e estudado...

B. Claro.

V.... e o outro tendo vivido?

B. Você viveu também, mesmo só...., mesmo tendo uma vida boa, você viveu... eu só vivi coisa ruim, só isso.... acho que por isso que eu sou do bem (risos)

V. Tendo tanta experiência ruim, falou: "não, o negócio é ser do bem porque...."

B. Mais ou menos.

V. Está à caça de emprego agora? Essa foi a sua preocupação no telefone...

B. É....

V. Você não queria marcar porque está com o tempo...

B. É, então....

V. ... ocupado pra arrumar um trampo.

B. É, não só o trampo, né? Cara? Acho que a gente tem que.... devagar e sempre conseguir as nossas coisas... eu tava.... minha vida estava bacana, aconteceram umas coisas que eu fiquei meio intrigado e eu não sei lidar com as coisas e... tô aí, entendeu? É isso....

V. Tentando lidar com elas?

B. Sei lá, só na hora.

V. No dia de hoje, você busca o quê?

B. Oh, no dia de hoje eu fui no Quixote ver se rolava de eu fazer uma oficina, cerâmica que eu trabalho com cerâmica também, que é uma coisa que eu gosto de fazer e.... agora.... ontem eu vim aqui pra ver se rolava um job aí pra fazer, aí falou que, a mocinha falou que vai rolar de fazer... M., né?

V. M.

B. M... pra gravar nome é meio.... ã.... eu tenho que.... acho que eu tô..... é 3 ou é 5, tá ligado? Nunca na primeira eu consigo.... 
V. Gravar?

B. Não, gravar não, se você for gravar com a câmera na primeira você faz, tô falando no pensamento....

V. Aí falaram que vai rolar alguma coisa mais pra frente?

B. É, que talvez role amanhã um trampo e que se Deus quiser vai rolar mais, né? Pagar o aluguel, comer....

V. Tá morando aonde?

B. Estou morando aqui na Bela Vista, aqui, numa pensãozinha bacana, né? Quartinho....

V. Você que paga seu aluguel?

B. É, eu que tô pagando.

V. Morando sozinho ou está casado?

B. Puts eu tava.... casa... sei lá, acho que casado, não sei, junto, é casado. Tava mó bom assim, tava gostoso e aí aconteceu essas coisas todas... e é isso....

V. Tá vendo como que fica?

B. Ã?

V. Tá vendo como é que fica? Deixando a vida andar pra ver como que fica?

B. Não, não, deixando a vida andar não! A vida não pode andar, você tem que andar, né?

V. Você tem que andar com ela?

B. Inclusive eu gosto de andar, eu ando bastante... pô.... acho que é por isso que eu sou assim.... magrinho (risos) bacana....

V. A cabeça vai pensando enquanto você anda?

B. Só na hora, mano...

V. Só na hora... eu cheguei a falar com a C?

B. Qual C.?

V. No telefone que você me ligou... você me ligou, ficou registrado....

B. Â.... ela é a pequena grande mulher...

V. É ela? Muito simpática no telefone...

B. Ela é muito legal, por isso que eu gosto dela.... se não der certo, firmão...

V. Tomara que dê, torço para que dê.

B. Eu também....

V. Quer dizer que ela é gente boa?

B. É..... é fogo....

V. Estar apaixonado é bom, pena que de vez em quando a gente sofre, né?

B. Mas sofrer te traz sorriso "Chora, chora que chorar faz bem..." (risos) Já ouviu, já ouviu essa já?

V. Não, que música que é?

B. É.... não lembro de quem que é assim, mas é bacana, é bem antiga, eu gosto de ... eu sou contemporâneo porém da antiga, sabe assim? Eu fui criado muito com as pessoas mais velhas, entendeu? Manja?

V. Aprendeu a gostar de coisas que os mais velhos gostam?

B. Não só de coisas que os mais velhos gostam... é ter um outro pensamento, né? Não é só futilidade, eu sei que a futilidade é bacana, tanto que me prendo tanto e não consigo ser tão fútil, sabe assim? Mas tô aprendendo.... a gente vai aprendendo.... devagar e sempre vai subindo a escada, tá ligado?

V. Onde que ela vai dar, você sabe?

B. A escada?

V. É. 
B. Só na hora (risos)

V. Não dá pra saber, né?

B. Só na hora (risos)

V. E a.... C.?

B. O que que tem?

V. Você disse que ela é uma pessoa bacana, o que você gosta nela? Que características assim que você curte? Essa mulher é...

B. (risos) o que que o brasileiro gosta? O que que o brasileiro gosta na mulher?

V. No geral.... do corpo dela.

B. Tá respondido, eu sou o cara que sou, eu gosto da cerâmica, eu gosto da modelagem, eu... eu aprendi um pouquinho na madeira, mas não foi a parada doida, eu comecei pichando, aí depois aprendi um pouco de pintura, né? Grafite essas coisas... ã.... e aí fui pra modelagem assim e me esbaldei com a forma, eu gosto da forma, tanto que eu vou no museu e fico pirando na forma, pego, os caras falam “meu, não pode pegar!" eu pego, é uma coisa louca assim, entendeu? Eu gosto de pegar, apertar assim! É uma coisa, tipo, sei lá, é eu, sai de mim... e... eu gosto da forma, manja? (risos) É muito bom!

V. E a cerâmica você aprendeu onde? Onde você...

B. Eu comecei no Liceu, na verdade eu tinha feito uma oficina na (?), que é uma casa, que era a central da casa de onde eu morava, e eu fiz uma oficina assim muito rápida e eu curtia e eu já fazia, na rua por exemplo eu mexia com arame, já fazia colagem...

V. Sozinho?

B. Sozinho, não, muita calma, na rua eu já fazia coisas assim... ã... fiz barquinho com papelão, monte de coisas com pet e etc e aí depois quando eu fui pra casa Pastoral do Menor, ô, pastoral não, hoje acho que é pastoral, agora é Associação de meninos, Cedeca, viche meu as coisas vão mudando....

V. Vão mudando de nome...

B. É, e.... e aí eu tipo gostava, queria fazer, rolou uma exposição, não sei o que aconteceu, várias coisas, muita informação, aí eu fazer, é... eu ia me matricular em desenho, né? Em desenho e pintura porque quando eu era mais novo, eu olhava pra você e te desenhava assim, sabe eu tinha essa facilidade...

V. Bacana.

B. É, e aí eu cheguei lá e tava tudo lotado, sabe assim os cara falou não tem mais vaga, aí eu fui, falei, vou conhecer os ateliês e aí eu conheci os ateliês e entrei no cerâmica assim... pirei nas esculturas, olhei aquele monte de escultura e falei, é aqui que eu vou fazer, aí fiz assim alguns anos, peguei o diploma, não sei onde está, perdi o diploma, que na minha vida eu sou o cara, hoje eu tô dando mais valor às coisas, sabe assim? Tô guardando tudo, sabe assim, tudo pra mim tem uma história, tem uma parada louca agora! Mas antes tipo assim, eu já não tenho uma casa e saía andando, sabe assim, tipo a última vez que eu vi minha mãe eu tinha montado a casa tinha tudo, aí ela sumiu e eu saí andando, deixei tudo, peguei uma mochila e fui embora, entendeu? E ... é isso assim. Agora hoje eu estou dando valor pra tudo assim, a gente vai aprendendo, devagar e sempre... Vou levantar aqui um pouquinho que a minha perna começou a doer, eu gosto de ficar em pé...

V. E a... quer que eu fique em pé também?

B. Não, fica à vontade.

V. A cerâmica você trabalha o que? Você faz escultura, você faz potes.... 
B. Então eu aprendi um pouquinho de cada coisa, né? Que aí eu fiz Liceu, aí depois eu fui trabalhar, aprendi várias coisas.. é, vídeo aqui.... fui fazer um monte de coisas assim, né? Eu fiz muita oficina, aprendi muitas coisas quando moleque assim e.... ã.... e quando eu tava, acho que estava morando na Aclimação, isso, estava morando na Aclimação, aí eu tava querendo voltar a mexer com barro, aí eu lembrei a casa de um amigo assim que era meu professor no Liceu, que chama Messias, Mané Messias e ele falou vem aí, não sei que, a gente não tem dinheiro pra te pagar, mas você come, não sei que, vou te pagando, eu morava na pensão, nessa pensão onde eu morei e deixei tudo e.... fiquei trabalhando com ele um tempo, aí depois foi... é... fui lavar carro, viche fiz um monte de coisa e aí tipo, como eu estava na pensão e saí, tipo deixei tudo as coisas ele tinha um quartinho a gente começou a trocar entendeu? Eu trabalhava e era como se fosse eu pagando o quarto, a gente foi trabalhando, trabalhando e assim foi vivendo, entendeu? Uma amizade bacana e é isso.

V. Lá você fazia o que?

B. Então, eu aprendi torno um pouco, né? Que eu não, não que eu não goste, é que eu não fui muito com a cara do torno, mas acho que a coisa é tudo que você treina, né? Tudo que você treina, mas eu, ele por exemplo me ensinou que... me dei bem, foi uma coisa bacana.

V. O que você fazia no torno?

B. Ah eu fiz uns copos, cheguei a fazer uns pratos, é fiz umas tinas, tina, né? Cauã no caso?

V. O que é isso, não sei?

B. Aquelas cumbucas que você come... toma sopa.

V. Ah, tá, mas é com barro, que material que é?

B. É, eu trabalho com barro.

V. Eu não sabia que torno dava pra fazer coisas de barro assim...

B. Como? Torno tem vários tipos de torno, a gente tá falando de um dos tipos de torno.

V. Acho que o que eu conheço é pra metal ou madeira.

B. Tem, tem vários tipos. Acho que o primeiro torno é.... se eu não estou enganado é o de madeira e é pro barro, depois vem os outros, aí você vê, moinho de cana e assim por diante, é que eu sou meio curioso eu vou lendo as coisas (risos)...

V. Vai aprendendo....

B. Isso... e aí?

V. Aí você tem habilidade com as mãos pelo que eu estou sacando?

B. Ah, sei lá, só na hora a gente vê, né?

V. Você não tem nenhuma foto das suas coisas pra eu ver?

B. Aqui não tem... tá tudo, tá tudo em goma, quer dizer na casa da minha pequena grande mulher.

V. Que pena, deve ser bonito, tenho curiosidade de ver.

B. Ah, se você quiser a gente pode sei lá, marcar mais pra frente....

V. Com certeza, se você tiver afim eu tenho curiosidade sim. E B. deixa eu te perguntar então?

B. Fala aí.

V. E aí você fala assim, pelo que eu entendi, veja se é isso, a sua experiência na escola não foi das melhores...

B. É, não que não foi das melhores, é que, é tipo assim, eu sempre fui meio excluído, sabe assim, pode... Fecha ali pra mim, faz o favor, é que está doendo os meus olhos? V. (Levantando e fechando a janela) tá muito claro? 
B. É... acho que é por isso que eu estou usando muito óculos assim.

V. Óculos escuro... quer que fecha tudo ou deixa um pouco?

B. Não, tá bom assim, tá legal, a luz tá bacana.. É... eu sempre fui excluído da escola..... aí teve essa parada, aí tipo reunião de pais, não tinha pai, sabe essas coisas que vai te deixando meio mal assim? Mas assim eu fui devagar e sempre e tô aí.

V. Tem vontade de voltar a estudar, não?

B. Eu tenho, só que foda que, por exemplo eu tava, a última escola que eu estudei foi aqui na Aclimação e aí o que acontecia? É... como eu estava trabalhando de garçom, tinha vez que eu tinha que trabalhar na quarta, na quinta e na sexta e é os dias que mais conta falta, assim, que mais vale e aí eu estudava à noite e pra trabalhar era à noite, aí tipo se fosse pra estudar de manhã não arrumava vaga porque eu era muito mais velho do que todo mundo (risos) aí nunca acaba dando pra conciliar as coisas assim, manja? E.... sei lá, é isso.

V. Você tem quantos anos agora?

B. Eu tô com 24.

V. 24.... tá super jovem ainda... dá pra estudar muito....

B. É, não, vou estudar, mas é que preciso arrumar alguma coisa, né cara?

V. Trabalho fixo, né? Pra poder a vida estabilizar?

B. Não sei se fixo, acho que o freela é bacana também, só que tem que arrumar um freela que, né? Tipo... sei lá, acho que o negócio é fazer um pouco de cada coisa assim, sabe? Devagar e sempre, nunca... é bacana um fixo, é bacana um fixo, só acho que depende do fixo também, que tem fixo que te sufoca...

V. Se for uma coisa de ficar numa sala fechada o dia inteiro nem pensar!

B. Não... não tem nem pensar, o negócio é na hora, a gente tem que ver ali na hora, eu não tenho, não falo assim "ah, é isso ou não é" entendeu? Porque... nunca foi assim cara, comigo.... eu sou meio 8 e 80 sabe assim? Meio espuleta, sabe pimentão, pimenta, sei lá.

V. Você era briguento?

B. Eu? Ah eu já saí na mão várias vezes, mas nunca fui de brigar não, sempre mais de virar as costas e sair andando, por isso que eu te falo, ficar quieto é melhor. Tô falando até demais. (risos)

V. E pra? Eu fico pensando em alguns meninos que acabam... eu conheci algumas pessoas na rua e de vez em quando eles, pra sobreviver, cometiam alguma, algum delito aí e iam pra Febem e alguns deles, infelizmente hoje faleceram, porque....

B. É, da minha época também muitas pessoas infelizmente faleceram, sumiram, nunca mais eu vi...

V. Nunca mais viu, né?

B. É e eu também tô aí devagar e sempre.

V. E alguns não, alguns falaram vou... eu lembro de uma família, quando eu trabalhei na rua, trabalhei na região de Pinheiros e era... era uma escadinha assim, dos 3 até 17 anos....

B. Firmeza.

V. E até quando eu tive contato os três mais velhos já tinham sido assassinados por motivos diferentes... um dentro da Febem, a outra foi fazer um programa com um cara que acabou ... tirando a vida dela, a outra menina foi atropelada num cruzamento, enfim... e aí eu ficava pensando assim, caramba como sair disso! Porque eu ia vendo aquela família... detonando aos poucos....

B. Mas é assim mesmo, é assim mesmo, é assim mesmo, não que eu queira...

V. Como você acha que se sai disso? 
B. Ah eu não acho nada, só na hora, só quem vive aquela coisa que sabe, eu não sei porque eu não vivi aquilo. O que eu vivi eu na hora lidei, eu depois bati com a cabeça e quase me soquei (risos) tá ligado? Sei lá...

V. Mas você morou na rua, né?

B. Morei.

V. Hoje você moraria?

B. Oh, eu vou te falar a verdade assim, se precisar cara, eu tô aí, tá ligado, só que eu fazer de tudo pra não, não fazer isso, mas... eu não quero, e tipo assim, se acontecer meu, desculpa aí, tá ligado? Eu tô aí, quem quiser me ajudar me ajude, quem não quiser, firmão, eu sou um cara do bem, eu.... se não der certo firmão, eu não vou me matar que eu não sou covarde, tá ligado? Agora eu não sei porque você falou se eu não moraria na rua....

V. Pra tentar entender assim, é.... Tem algumas situações na vida da gente, pelo menos na minha tem, que eu não gostaria de voltar a ela....

B. Claro, lógico...

V. ... e aí é isso que você falou se, se tiver que voltar vamos encarar, mas senão vamos batalhar pra coisa.... ser diferente.

B. Eu acho que você não deve nem pensar nisso, né? Acho que a coisa é pensar positivo, sabe assim, eu penso positivo todo dia, eu desejo coisas boas pra todo mundo e... o que desejarem pra mim, sabe assim... é isso aí cara, eu não penso nada disso e eu acho que você não deveria nem falar isso, desculpa. Tá ligado? Eu não sou seu pai, sua mãe, nem sou mais velho que você, mas eu acho que você não deveria nem pensar isso...

V. Do que eu não deveria nem pensar?

B. Isso que você falou, não quero nem repetir, nem pensar nisso, isso aí é uma coisa ruim, sai daqui....

V. Sai de mim....

B. Né?

V. Tá certo, tá certo.... Do hoje você pensa no amanhã? Ou do hoje você pensa o hoje?

B. Só na hora mocinha.... (risos)

V. Acho que você pensa só o hoje, pela resposta...

B. Não, só na hora, não sei, só na hora....

V. Só na hora.... por hora você acha que deu?

B. Deu o que?

V. Você ficou satisfeito com a nossa conversa?

B. Não sou eu que tenho que ficar satisfeito, é você.

V. Somos nós dois!

B. Eu?

V. Opa!

B. A é?

V. Eu acho, senão, se você tiver que fazer alguma coisa que você não está afim, que está te fazendo mal....

B. Não, nada tá me fazendo mal, é só você falar essa coisa aí de voltar pra rua, essas coisas, que você não deve pensar nisso cara! Sabe assim, é positividade, é coisas boas. Acho que todo mundo deve viv, deve pensar coisas boas, tipo eu por exemplo acredito muito na palavra, sabe assim, nas pessoas e... é por isso que eu tô aí cara, eu acredito, é acreditar e ter fé, eu tenho fé.

$\mathrm{V}$. Você tem um sonho? 
B. Todos nós temos, eu não tenho um, acho que eu tenho vários... até demais (risos)

V. Qual é seu maior sonho?

B. ... meu maior sonho não dá pra te falar porque não tem um maior assim...

V. Tem muitos?

B. É, sei lá, acho que todo mundo tem todos, né? Quer ter tudo, eu sou mais simples, vim debaixo, mas eu quero ser alguém, ser uma pessoa de bem, sabe assim? Fazer o bem, é.... ter o que eu não tive, dar uma boa vida pra minha mulher, que eu tiver e.... sei lá, é isso, viver, viver bem, sei lá... poder viajar, conhecer os lugares, ã.... mesmo que eu não seja um artista, ã.... continuar fazendo o meu barro, ã.... mesmo que eu não vire um câmera, continuar filmando, mesmo que eu não seja um cantor, ou um compositor, mas continuar fazendo o que eu faço, ser o cara simples que eu sou, entendeu? Assim e devagar e sempre a gente tá aí. Entendeu?

V. Posso arriscar dizer que você já é um artista, mesmo que não seja conhecido do público?

B. (risos) oh que firmeza! Se você acha, firmão.

V. Eu acho sabe pelo que? Pelo jeito que você falou, falou com, com....

B. Tô te falando, tudo que eu te falo é com o coração...

V. Mas a hora que você falou do barro... eu não estou vendo seu olho por causa dos óculos escuros, mas eu acho que ele brilhou, sabe assim? Deu a impressão que você curte muito, você é um artista!

B. Firmão, é eu acho que... sei lá, não é só do barro não, eu gosto muito do barro porque o barro... ele.... ele tem forma sabe assim? Ele tem vida... ele é que nem a gente, ele lembra das coisas sabe? Manja?

V. Como assim ele lembra?

B. Ah, mexa no barro, faça uma aula, se quiser eu... sei lá, eu tô querendo... por exemplo aqui no Quixote, no Novolhar por exemplo, eu tô querendo dar uma oficina de cerâmica pra molecada aí faz tempo, só que eles não querem, falam que não tem forno, não sei que, eu sempre quis, mas sempre, tudo... é aquilo que eu te falo, psicólogo é tudo uma coisa enrolando, as coisas são mais simples, sabe? É só querer....

V. Podia ser mais simples, né?

B. Podia não, tem que ser, sabe assim? Tudo mais simples e é isso.... se um dia puder ou vá fazer uma aula de cerâmica, sei lá tem... posso te indicar uma pessoa?

V. Pode.

B. Chama M.... é ali na....... é na Vila Mariana, só que eu não lembro o nome da rua agora.

V. Mas aí ele pegaria alguém que não tem a menor noção de nada?

B. Claro, lógico... e vai mexer, é muito bom, é uma coisa gostosa... é como se fosse uma pessoa, só que é da natureza (risos) quer dizer, as pessoas são da natureza e é isso....

V. E hoje em dia você mexe ainda com barro?

B. Ah... a última... eu....mexo.... eu até tenho um pedaço de barro lá em casa comigo na pensão e tô.... ah, a gente vai fazendo, né?

V. Como que é o processo, o barro que tem lá ele tem que está mole, antes de queimar ele ainda aceita....

B. Vá fazer aula, vá fazer aula que você vai aprender, eu não vou falar....

V. Vai me deixar na expectativa até o dia que eu for fazer aula? 
B. É, se você for, eu acho que você não vai, essa não é sua praia, sua praia é pesquisar, pesquise bastante, faça boas coisas, pense positivo, faça coisas boas pras pessoas e é isso, é isso que eu te falo, assim, manja?

V. Assim que é a vida pra você....

B. Fazer coisas boas, eu tipo assim ó, eu já roubei, eu já fiz várias coisas, só que quando eu fiz as coisas erradas na hora, tipo assim, não foi no mesmo dia ou na mesma hora, mas depois veio, foi errado, sabe assim? E eu aprendi que o negócio é, mesmo que você peça, oh por favor me dá? Que nem hoje, eu estava, tipo ó eu tô com.... 7 mangos, tá ligado? Aí eu tava, só que de manhã eu estava só com 4, aí peguei o metrô sobrou 2, tá ligado? Depois tomei um açaí porque... é como se fosse um prato de comida, né? Aí ainda tinha 10 reais, troquei agora estou com 7 reais e..... tipo.... só vivendo, sabe assim? Só devagar e sempre na pegada.

V. Se você faz alguma coisa errada um tempo depois você saca que fez.

B. Então, eu estou pensando aqui como eu posso te falar que eu não tenho essa informação toda, sabe assim, por isso que eu estou te falando, logo mais quando a minha vida melhorar, as coisas andarem um pouco melhor, é.... aí eu acho que eu vou poder te dar, sabe assim? Eu queria estudar numa escola boa, sabe assim, manja assim? Aprender, sei lá, fazer uma USP, alguma coisa assim, sei lá, ou senão, só Deus sabe, só na hora, né?

V. Você já freqüentou a USP de alguma maneira? Já foi fazer algum tipo de oficina lá, alguma coisa?

B. Então, é tipo assim a minha pequena grande mulher ela sempre falou, vai lá, não sei que, só que eu nunca tive tempo assim, eu tô querendo, acho que eu vou, deixa melhorar agora, eu pagar o aluguel que inclusive não paguei todo o aluguel, preciso arrumar uma grana, por isso que eu vim aqui falar: meu, por favor, entendeu assim? É fogo, sei lá eu vou, mais pra frente eu vou começar tentar a freqüentar umas aulas lá, ou sei lá, aqui também tem essa faculdade aqui na Brigadeiro e é isso.

V. Essa aqui eu não conheço, a USP eu conheço porque eu estudo lá.

B. A é? É, você estuda lá, faz o que lá?

V. Mestrado em Psicologia.

B. Ó que bacana.

V. E...

B. Você abriria alguma porta pra mim lá? Sei lá?

V. Eu acho que sim, no sentido assim, a universidade é pública, ela não recusa ninguém que esteja a fim de fazer uma aula alguma coisa assim, a não ser que o professor fale ó...

B. Não quero você aqui (risos)

V. Não quero ninguém estranho, aí ele recusa qualquer um, entendeu? Mas no geral a universidade tem.... agora em relação a ... como a universidade é toda fragmentada, quer dizer, psicologia uma coisa, a ECA que é a escola de comunicação e arte....

B. Sim...

V. Que eu suponho seria um lugar pra você....

B. Bacana, mas eu acho assim.....

V. ...se encaminhar....

B. Eu acho que se você aprender um pouquinho de cada coisa, na sua cabeça você constrói uma outra coisa...

V. Mas eu diria pra você, vai lá....

B. É mesmo? 
V. Dá uma sapeada, conversa, principalmente com o pessoal de Centro Acadêmico que estão lá na graduação...

B. Você escreveria pra mim um lugar pra eu ir lá e pesquisar?

V. Sim....

B. Eu tenho papel aqui... que aí você vai estar me indicando, entendeu? Sei lá, ó....

V. Sabe chegar lá? Tem um Butantã-USP por aqui?

B. Sei, sei.... Escreve aí.

V. A ECA, que é abreviação de Escola de Comunicação e Arte...

B. Então, eu tive uma vez... sei lá uma namorada, ela fez jornalismo, ou faz jornalismo lá na ECA, isso...

V. Então, lá tem assim, eu sei que tem o núcleo de cinema, tem o núcleo de jornalismo....

B. Bacana...

V. Tem uma porção de coisas, então eu sugiro pra você ir no Centro Acadêmico, que é uma sala onde os alunos da graduação se reúnem e tudo que tiver de algum tipo de curso que aquela unidade oferece...

B. De grátis....

V. ... eles vão saber te dizer...

B. ...entendeu. Será que se eu chegar lá na unidade assim como eu estou....

V. Sim, perfeitamente bem vestido, nenhum problema...

B. ... é que eu não estou com muita roupa...

V. Não esquenta... o que você vai ver de bicho grilo na Eca....

B. É porque eu já conversei com muitas pessoas e é mais playboyzada que entra lá, né? É pouco...

V. É, porque enfim a pessoa tem que ter estudado em boas escolas...

B. Pra acabar passando, é.... então um cara que não estudou nada, pior ainda....

V. Não, você tem que terminar o colégio pra tentar.... mas antes disso, sei lá falta quanto tempo pra você terminar o colégio? 3 anos? Você parou na oitava?

B. É.

V. Não precisa esperar 3 anos! Vai essa semana lá, amanhã é sexta, sexta nunca é um bom dia porque os alunos nunca estão muito por lá, mas... é... outra coisa que eu tenho, que eu posso te dar é o telefone que chama da USP Geral, aí você pega o telefone do Centro Acadêmico da ECA.

B. Certo, anota aí por favor?

V. USP geral, você liga, você vai falar com uma telefonista, aí você pede, queria o telefone do Centro Acadêmico da ECA, ela te dá...

B. Certo.

V. Aí você já procura algum aluno que possa te ajudar, o horário de funcionamento...

B. Aluno? Mas não pode ser com professor, chegar lá e conversar com um professor?

V. É mais difícil você ir direto pra um professor, é mais fácil você ir via um aluno que te leve a algum professor...

B. Entendi...

V. Entendeu? Costuma ser bem mais fácil....

B. Você acha que pode ser ... sem ser essa semana que vem, na outra?

V. Pode, pode.... só não pode ser em período de férias, que aí o pessoal não está lá, mas....

B. Entendeu... firmão...

V. Vai fazer, a universidade ela tem o direito, direito não, ela tem o dever de oferecer coisas pra comunidade.... 
B. Só que eu moro aqui na Bela Vista agora, né? Não moro lá perto....

V. É, isso pode ser um empecilho pra algumas coisas, mas talvez não pra tudo....

B. Firmão... quem trabalha com cerâmica lá?

V. Não tenho a menor idéia, não sei, não conheço mesmo....

B. Você faz o que mesmo lá?

V. Mestrado em Psicologia... é que o prédio da ECA e da Psicologia são visinhos...

B. É perto da....?

V. É perto do ponto final do ônibus.

B. Sim, mas ali tem.. é que eu fui numas festas ali na.... faculdade de arquitetura.

Desenha aqui o mapa, você manja desenhar o mapa?

(desenhando o mapa)

B. Eu gostaria de conhecer a Psicologia também que eu gosto bastante, sabe assim?

V. Então, na psicologia eu sei que o Centro Acadêmico é entrando no bloco de alunos, é a primeira porta à esquerda.

B. Psicologia? Aí eu falaria com quem lá?

V. Com o pessoal do Centro Acadêmico, eles vão conseguir te....

B. Falar alguma coisa...

V. É, porque lá eu sei que tem atendimento pra comunidade é o cursinho, mas aí você tem que ter terminado...

B. O segundo grau....

V. O segundo grau.

B. E aquela questão de fazer aulas? Como se diz?

V. Como ouvinte?

B. Isso...

V. Então, aí se você tiver acesso a internet, dá pra você entrar.... é. Todo o site da USP é assim www.usp.br e aí você escolhe a unidade que você quer, ou da psicologia por exemplo é ....

B. Mas precisa br, a gente tá no Brasil?

V. É, precisa.... www.ip.usp.br e a ECA, provavelmente, não tenho certeza, todos lá são assim www.eca.usp.br, aí você vai ter o quadro de aulas, pra você vê que aulas que têm, que horário que é...

B. Firmão, não precisa gritar, tô ouvindo (risos) Certo... firmão....

$\mathrm{V}$. Mas é isso, corra atrás que eu acho que....

B. Tem uma coisa que eu ouvi há muito tempo atrás que é meio.... as palavras são meio contraditórias, mas é verdade, pra você correr atrás, você vai ficar sempre atrás, vai a frente...

V. Corra a frente....

B. A gente pode ver que o vencedor da São Silvestre tem que tá na frente...

V. Esse ano eu vi, ele passou grande parte da prova à frente de todo mundo.

B. Não é verdade? E aí, mais nada?

V. Nada, acho que é isso.

B. Ah é? Firmão. Você acha que foi produtiva, sei lá?

V. Foi, foi sim.

B. O que você aprendeu, fala pra mim?

V. O que eu aprendi? 
Transcrição Entrevista Douglas

23 anos

Entrevista concedida dia 28/03/2007 nas dependências da Associação Mutirão.

V. Eu queria que você começasse contando um pouco da sua vida, onde você nasceu, quantos anos você tem....

D. Eu tenho 23 anos, nasci dia 31/12/83, morava ali na Vila Constança, Zona Norte. Com seis anos, sete anos, mudei aqui pro.... Filhos da Terra. Daí estudei aqui no Mutirão, comecei a estudar com 7 anos, aqui próximo ao João Batista, daí o que acontece... várias dificuldades em casa, problemas com a família, como que eu fui assim criado pela minha mãe, meu pai eu conhecia, só que ele morava longe e eu ia visitar ele de vez em quando, chegou um tempo que eu não visitava mais ele...

V. Quantos anos você tinha, lembra?

D. Quando eu não via mais eu tinha uns... quando eu nunca mais vi ele eu tinha uns 9 anos de idade. Daí o que acontece... eu comecei a vim pro Mutirão, estudei no Mutirão tudo, que foi uma ótima coisa, só que, como você não é criado pelos pais, você sempre tem uma festividade na escola, dia dos pais... como eu fazia teatro é.... até aqui no Mutirão, na escola, isso aí, sempre tinha aqueles brinquedinhos, aqueles bagulhos pra dar pros pais, tudo, eu pegava e não tinha pra quem dar, via as crianças abraçando tudo ali e você ficava assim mal... que você ficava sentido, porque você não tinha ninguém ali pra você está comemorando junto, a única pessoa era a minha mãe, minha mãe trabalhava muito como funcionária pública, daí o que acontece, em... daí eu comecei adolescente tudo, comecei a trabalhar tudo, daí eu ganhei uma oportunidade de serviço, já conhecia as pessoas da malandragem, já conhecia as pessoas certas, as pessoas erradas, daí eu falei "mãe, arrumei um serviço como entregador de pizza"...

V. Você tinha quantos anos?

D. Eu tinha é... 14, 15, 15 anos, daí ela pensou, ela e meu irmão mais velho pensou que eu ia catar a moto pra ficar zoando, aprontando por aí pela rua, daí ela falou "não vou te dar!", que não sei que, daí eu acabei discutindo com minha mãe, com meu irmão, também não quero mais nada de ninguém, não quero saber, "já que vocês não vão me ajudar então eu vou me ajudar do meu jeito, vocês não podem me arrumar o dinheiro, então eu arrumo do meu jeito". Aí eu comecei a roubar, conhecia já amigos meus que roubavam, comecei a roubar, né? Ia no supermercado, tudo....

V. Você pegava as coisas ou pegava dinheiro?

D. Pegava dinheiro, é.... como que chamam 155 , né, artigo 155 , roubo... porte leve, né? Daí o que acontece, abria as lojas, arrombava, pegava as coisas... Daí quando eu tinha 20 anos, pra 21 anos eu peguei e falei, não, já chega de fazer 155 eu vou fazer com revólver, à mão armada, que é 157, daí fui eu mais um outro menor, precisava de dinheiro que eu queria fazer a minha festa de aniversário, queria ajuntar que a gente estava com problema com polícia também, que tinha confundido eu e o meu primo com outra pessoa, não, queria matar nós mesmo, por causa que tinha um "irmão", um irmão do PCC, que chama, é.... que chamava o mesmo apelido que meu primo, daí o que acontece, eles vem atrás de nós, que queria matar nós que pensava que era eles. Aí nós teve que sair fugido daqui... aí quando nós voltamos, nós falamos "não, não quero mais saber, rezamos, pedimos tanto pra Deus pra não entrar nessa vida, não adiantou, agora nós vamos entrar de cabeça, daí começamos a roubar, compramos arma, roubamos, compramos arma, fazendo festa toda semana, e assim foi indo... Daí eu com 20 anos, eu faço aniversário dia 31 de Dezembro, dia 30 de 
Dezembro eu fui... eu mais um menor aqui no B. efetuar um assalto, aí chegando lá nós pegamos, fomos abordado pela viatura da PM, ao qual da que eu fui preso da primeira vez, aí chegou, fomos direto pra... aí bateram, pra... falaram que era o menino que estava comigo, daí foi apresentar.... a vítima falou que foi ele, o de menor, levaram a gente pra 73, ao qual prenderam nós, daí eu fiquei cinco dias na 73 e fui pra trinta... 39 de Bonde, né, que chamam de Bonde o caminhão que leva, o ônibus que leva de uma delegacia pra outra.

V. Daí vocês ainda não tinham sido julgados?

D. Não, não tinha sido julgado. Daí fiquei 3 meses na 39 pra ter o primeiro julgamento. Daí do julgamento foi uma rápida atrás da outra. Foi na Primeira Vara Criminal do Fórum da Barra Funda. Daí fui condenado 1 ano e 10 meses em Regime Semi Aberto, até aí eu já tinha pegado 7 meses na 39, daí eu fui de Bonde pra Franco da Rocha.

V. Como que funciona o Semi Aberto?

D. O Semi Aberto ele é assim.... aliás ele é Semi Aberto pra quem tem dinheiro porque você tem que sair pra fora, você sai pra fora de manhã....

V. É obrigado a sair?

D. Não, só quem trabalha fora e você está trabalhando aqui fora, você tem que depositar $\mathrm{R} \$ 300,00$ na casa, todo mês. Se você não depositar esses $\mathrm{R} \$ 300,00$ é cortada a sua carteirinha, você não sai mais.....

V. E você sai todo dia e volta todo dia?

D. Isso, até sábado, domingo você não sai.

V. Agora me diz uma coisa, você estava preso, você não tinha trabalho, como que te colocaram no Semi Aberto? Arrumaram trabalho pra você?

D. Isso, eu trabalhava dentro da Colônia, tem a fábrica lá dentro, mas é dentro e não sai pra fora, de jeito nenhum.... Que nem, eu falo que é pra quem tem dinheiro, por quê? Porque tem muitos esquemas lá dentro que muitos compra a carta de emprego, daí sai pra fora, volta a roubar, paga os $\mathrm{R} \$ 300,00$, daí desses $\mathrm{R} \$ 300,00$ fica acho que $75 \%$ pra casa, $20 \%$ pra tá... é.... conta liberdade, né? E o resto você pega $\mathrm{R} \$ 220,00$ no final do mês....

V. No outro mês você pega 220 do dinheiro que você depositou e depois você não vê o outro....

D. Só vê uma metade dele que é o que você pega quando você é liberto de vez... tá... tá depositado. Agora o resto que eles falam que é pra pagar a casa, né? Pagar tipo os faxinas que limpa o prédio, limpa a sala dos diretores....

V. Mas a cadeia não é pública?

D. É, isso que nós não entende, né? Daí... pra pagar o preso que trabalha na cozinha, esses negócio... e tem as fábrica lá, que nem ali em Franco da Rocha tem a "Plastifex", tem a "Satup", são fábrica, tipo... loja... tipo fábrica de Polietileno. É fora da cadeia a central da loja, só que elas têm um galpão dentro da cadeia... lá o que acontece, você vai lá, você faz, você faz o serviço, sai sete e meia e volta 8 horas, daí você entra e sobe pro prédio. Daí tem também a faxina que fica lá e limpa o prédio todo e.... eu fiquei 2 meses e 14 dias lá, daqui... dessa outra...... da primeira cadeia aí eu montei o exame que é o RA que chamam de exame... é o Regime Aberto, pra você montar o seu Regime Aberto, o RA... é o Regime Aberto, tem o LC que é Liberdade Condicional, que chamam o antigo PAB, o RA.

V. Você que monta isso?

D. Não, lá são os advogados da casa mesmo, já vem o seu processo ele já caminha, só execução, eles montam o pedido, vai pra mão do juiz, do promotor, se eles achar 
que você merece sair eles te dão o Exame pra você ficar assinando no Fórum. Daí saí, daí fiquei... saí dia 14 de setembro, agora não me lembro o ano direito, daí o que acontece.... eu fiquei 5 meses na rua....

V. Você voltou pra casa da sua mãe?

D. Voltei pra casa da minha mãe, nunca saí daí... e até o pessoal, meus próprios familiares tinham medo de mim porque eu andava armado, andava é.... com vários caras, esses negócio assim.

V. Desde que idade D?

D. Eu desde os 16 anos. Já nessa idade....

V. Já nessa idade com uma arma na cintura e fazendo 155 ?

D. Nessa época do 155 eu não andava armado... só depois que nós voltamos fugido de B P.

V. Como foi essa história?

D. Por causa dos polícia que queria matar nóis, daí como nós já conhecia uns ladrão, algumas pessoa assim, daí ligamos pra dentro da cadeia pra entrar em contato com esse "irmão" pra saber qual era a real da história porque tinha prejudicado pessoas inocentes, daí o que acontece, daí nós achou tudo, daí foi preso esses irmão, e nós tinha que tá fugido porque os polícia queria arrancar a nossa cabeça de qualquer jeito, andavam por aqui pelo bairro perguntando de nós e nós fugimos, ficamos 3 meses fora, daí voltamos, tudo e graças a Deus não aconteceu nada mais, daí aconteceu tudo, fui preso, essas coisas toda, daí fiquei 5 meses na rua, depois que saí da cadeia fiquei 5 meses na rua, daí eu andando de bicicleta, eu mais meu primo, mais 2 amigos nossos, aliás, 3... daí..... 2 amigos nosso viu um rapaz alcoolizado na rua, daí falaram "vamos tomar ele", daí os moleques foram, tomaram ele, tudo, daí nós indo embora, paramos no H. aqui na C., daí fomos atua... atualizado, preso de novo...

V. Como que eles descobriram?

D. Por causa que o rapaz que estava meio alcoolizado chamou a polícia, daí nós estava em frente ao H. e.... o que acontece, chegamos... daí já acharam nós pelas roupas, pelas bicicletas e nós fomos preso de novo fomos eu e eles, assinamos 157 e 288 que é formação de quadrilha, com 4, com 5. Daí um foi embora porque os polícia conhecia ele e liberou ele por causa que ele trabalhava num negócio.... num bar, numa lanchonete em S., que o dono de lá era policial também e daí como eles conhecia, soltaram ele.

V. Ele pagou?

D. Não pagou nada, quer dizer falaram "quando nós for lá vocês vão liberar umas feijoadas pra nós". "Não, pode ir que está na minha conta!" Aí soltou ele. Aí nós fomos, ficamos um dia lá pra... pro Belém, o Belém 2, que é o Sistema CDP - Centro de Detenção Provisória, daí o que acontece, ficamos lá.... nossa, o pior de tudo é a 72 , que nós saímos da... 39, não, da 20 e fomos de Bonde pra trin, pra 72 . Você fica uma noite lá aguardando o caminhão pra vir buscar os presos, né? Daí lá, nossa! É horrível, lá o chão é todo molhado, chão de concreto, cimento puro, todo molhado, o lugar não entra ar nenhum, cada rato que o rabo dele é quase do tamanho do meu braço... horrível, horrível, horrível, horrível, precária mesmo, tanto que, nós mesmo que estava ali, nós estamos pagando pelo que fez, não merece nenhum privilégio, mas ali a consequiência é terrível, até o rato chegava a arrastar até o saco de lixo, de tão grande, de força que tinha.

V. E vocês dormiam ali.... 
D. Ah, não conseguia dormir, né? Daí de manhã cedo, debaixo do sol, colocava o caminhão, o chamado Bonde, lá dentro lá, debaixo do sol a pampa, depois pra acorrentar a gente nos braços e nas pernas pra gente ir pro Bonde.

V. Vocês iam acorrentados?

D. Acorrentados.

V. E por que debaixo do sol?

D. Ah, pra castigar.... só pra castigar. Daí saia de lá nós ia lá pra.... como que é o nome? Pra.... pro Hospital das Clínicas fazer perícia, mas que não adianta nada...

V. Vocês apanharam lá?

D. Não, eu apanhei no dia que eu fui preso, na delegacia, eu mais um amigo meu, tomamos umas bicas dos polícias...

V. O que você acha disso?

D. Ah eu acho errado, né? Porque ali nós já estamos, já estamos algemados, já não estamos mais armados, daí vai querer agredir, porque aí eu já acho que é abuso de autoridade, não é verdade? Agora se nós estivesse armado e eles também ou numa fuga e eles atirassem, aí ia ser uma defesa deles, tudo... Não criticando nem um lado nem o outro, que os dois lados são errados... Daí de lá nós fomos direto pro Hospital das Clínicas e de lá pro CDP do Belém, daí nós fica um dia na inclusão. A inclusão é naonde fica lá pra liberar os RO que é Regime de Observação, pra depois entrar, porque fica muito cheio, então você chega um dia, no outro dia você vai pro RO, daí cê fica o RO dentro do pátio, tem o pátio e tem duas celas que é celas A6, A7 e A8, que colocam o RO no meio dos presos tudo...

V. O que é esse RO?

D. É Regime de Observação.

V. Como funciona? Fica um funcionário ali?

D. Não, o funcionário vem e te prende dentro da cela, daí você fica sete dias lá dentro...

V. Sozinho?

D. Não, mais um monte de preso, fica 8 , não dezão, fica 10 dias preso lá dentro...

V. Como se fosse uma cela fechada?

D. Isso. Fica lá dentro em Regime de Observação.

V. Fica sentado sem fazer nada?

D. Isso, você deita porque não tem televisão, então você deita nas camas, dorme, chega comida você pega pela grade, né? A grade pega os bandeco... Daí isso daí é assim, aí passa os 10 dias que é o Regime de Observação e aí você vai pro convívio, né? Que chama o convívio e lá você vai ser dividido pra cada raio, tem o raio ímpar e o raio par. No Belém 2 o raio ímpar recebe visita de sábado e o R2 que é o par recebe visita de domingo. Daí o que acontece, daí nós é pago nos raio, no final do mês você escolhe que raio que você quer ir, você fala não, quero mudar de raio, né? E de rua, aí você vai e escolhe o número da rua e cê troca.

V. Troca por quê? Se você conhece alguém....

D. Isso. Que nem, nós fomos pago, que chama lá, fala pago, né? Onde nós ficamos, os funcionários colocaram a gente no raio $1 \ldots$

V. Mas o pago não tem nada a ver com liberar dinheiro ou coisa assim?

D. Não, é pago é o modo que eles falam, né? Que você ficou lá, então...

V. Você está "pagando pelo que fez"...

D. Isso. Daí nós ficamos lá, daí meu primo mudou pro raio 1, onde ficava o piloto da cadeia, piloto da cadeia é o "irmão" o "irmão" do PCC responsável pela cadeia, pela 
disciplina total, pra não acontecer rebelião, pra não acontecer nada, é.... tá lá, tipo, de frente pra bater com o diretor, né?

$\mathrm{V}$. Qualquer coisa que os presos quiserem é essa pessoa que vai...

D. Isso, ela vai recorrer. Então tipo assim a.... tão barrando, os funcionários estão maltratando as nossas visitas lá fora, como que tem também e então o que acontece, daí o "irmão" vai chegar no diretor e vai falar é isso, isso, isso e isso.

$\mathrm{V}$. Ele tem livre acesso a diretoria?

D. Tem livre acesso.

V. Quem escolhe essa pessoa?

D. Isso daí é um irmão que sai, tá no piloto, deixa outra disciplina, quando ele sai, o outro que vai assumir. Então o que acontece, daí...

V. Seu primo mudou pra lá...

D. Isso, mudou pra lá, eu peguei e fui junto, passou o outro mês e eu fui lá, ficou dois parceiro meu no raio 5 e eu fiquei com ele no raio 1. Daí ficamos lá, eu mudei pro barraco que é o $X$, que são $1,2,3 \ldots .9,10,11$, são 11 camas, né? São 11 camas de concreto e cada cama vai um colchão, pra dormir 2 pessoas, uma de cabeça pra cima e outra de cabeça pra baixo e a última, e uma reservada pra fazer a barraca, pra ficar a alimentação nossa. Daí o que acontece, daí chega visita, visita de sábado e é permitido levar algum tipo de comida, não são todos, tipo bolo recheado, essas coisas não entra, é só comida que não é com recheio, esses negócio, refrigerante não pode entrar, Fanta Uva, suco, nada assim. Leite em pó, esses negócio já pode, daí nós colocava tudo na barraca pra dividir pra todo mundo, independente de quem teve visita ou não era dividido pra todo mundo e segunda-feira era o dia de Jumbo, que é separado, que é o dia que manda sabonete, pasta de dente esses negócio...

V. A cadeia que manda?

D. Não, os parentes, daí, quem não tem.... que a cadeia não manda isso, no CDP, esses negócio eles não dão, a única coisa que eles dão é a roupa da casa, que é obrigado a vestir e.... a única coisa só. Daí o que acontece, quem não tem você vai ter que fazer alguma atividade pra você, tipo você vai ter que trabalhar lá dentro pra você ter seus produtos de higiene, como não entra é... dinheiro dentro, lá dentro, então a forma de pagamento é o cigarro, daí o que acontece, você vai lavar roupa pro outro, você lava três peças, o cara te paga $R \$ 3,00$ dá 2 maços de cigarro, e com esse cigarro você fuma, você corta o cabelo, tudo é o maço de cigarro. A pessoa tem que se virar, fazer atividades, que nem lá é tudo dividido as atividades, tem o rapa que é a pessoa que lava a barraca, limpa o banheiro, esses negócio, tem o capeiro que fica na capa pra ver se a polícia entra pra dentro da... É o negócio nosso do barraco, entre nós... Daí depois disso se você passou, hoje é meu dia de ficar na capa, na capa é a grade, pra ver se de repente o funcionário entra, porque lá nós temos celular, então como acontece, como não pode eles ver, então o que que acontece, fica um na capa olhando se um funcionário vem, se o funcionário vem nós fala "oh, funcionário na ilha" aí vai e esconde o celular.

V. Como o celular entra?

D. Ah, entra pelas mulheres e também, como agora que tem por causa do raio x que tá tendo agora, ele não mostra, mas ele apita se passar, então o que acontece, não entra mais, entra agora pelos próprios funcionários mesmo.

V. Eles querem o quê em troca?

D. Dinheiro, tá na faixa de 3 a 4 mil reais pra poder você estar com um celular bom lá dentro. É, informação também, mais isso é mais do pessoal que é da faxina, 
naonde que tem mais acesso aos funcionário. Daí nós ficamos, fiquei lá, tudo, no raio 1, daí fui pro castigo, por causa que eu caí com um celular.

V. Eles viram você com um celular?

D. Isso, acharam um celular, como o celular era meu eu tive que me apresentar, daí fui pro castigo, daí fiquei 8 dias. Castigo é uma celinha, uma sala pequena, que só tem uma cama só, mais ou menos é uns 2 metros por 1 metro. Daí tem o banheiro, tem uma caminha, uma cama aqui e o chapão de ferro. Você só vê a muralha, mais nada, e até a comida que você recebe, você recebe pela uma frestinha que tem na chapa. Daí fiquei 8 dias lá, só saí mais cedo por causa da anistia do dia das mães. Daí foi quando teve agora o atentado, a Mega de 2006. Eu tava lá dentro também, daí fiquei, daí descemos no sábado da festa do dia das mães, que era pra ser tomada a cadeia no sábado mesmo...

V. Foi aquela que foram várias cadeias ao mesmo tempo?

D. Isso, daí o que acontece, por causa que ali foi uma.... foi uma coisa que tivesse uma reunião entre todos os "irmãos", que todas as cadeia tinham que virar, por causa que eles tavam negando muitos benefícios pra nós, porque nós estava pedindo anistia porque tem pessoas que ela não tem família, tipo não tem irmão, não tem pai nem ninguém, a única coisa que tem é primo ou tio e não pode visitar, não dá direito, não pode visitar, sobre a roupa também, que a roupa nossa que nós usava era como se fosse uma roupa de.... de lixeiro, né? Que é o coletinho laranja, a calça laranja, né? E fora que você vai pro fórum vestido com essa roupa também, sem tênis, de chinelo, aquela humilhação do fórum, é jogam spray de pimenta na nossa cara....

V. Quem joga?

D. Os polícia lá dentro do fórum, bate... é porque sempre tem isso.... nós tem.... é como o fórum é uma coisa demorada, que você vai de manhã cedo, cê sai de manhã cedo umas oito horas da manhã, daí você vai e fica na inclusão do CDP, daí vem o Bonde, daí você vem lá, daí chega o Choque, daí você tem que tirar sua roupa todinha, bater no chão, abaixar três vezes, mostrar a língua, sobe pro Bonde, lá dentro fica maior demora, daí tem que fazer tudo de novo, daí você sobe lá dentro fica na cela até ter a sua hora de julgamento, daí bom, você já está cansado, morrendo de fome, que a única coisa que eles dão é dois pão com queijo e um suquinho, daí você quer ir embora logo, daí começa a gritar "olha o Bonde, solta nós, manda nós embora", daí o que acontece, daí sempre tem algum bravo, policial bravo vem e joga spray de pimenta em nós, leva a gente pra uma outra cela, bate em nós....

V. Dentro do Fórum?

D. Dentro do Fórum e isso, porque aí é lá embaixo, lá embaixo é só polícia, ninguém ouve nada, é tudo no meio deles, a única coisa que vê é nós, spray de pimenta na cara que....tossindo sangue, cuspindo sangue pelo nariz, porque sufoca a gente vai tossir aquilo queima, é horrível. Fora que também te manda tirar nossa roupa, joga spray de pimenta e aquilo onde cata queima. Daí nós ficamos lá, daí voltando desse do.... voltei do castigo, fiquei na sexta-feira, no sábado era para ser tomada a cadeia, como nós não quisemos tomar com as visitas, que era aquele alvoroço, tudo e porque nós não tinha recebido a, o...... o aval, né? Que é de todas as cadeias, daí o que acontece? Ficamos na nossa, daí no domingo que nós fomos tomar a cadeia, daí o Belém 1 virou e logo em seguida virou o Belém 2, só que nisso os Agentes já estavam preparados, já estavam armados, atiraram pra cima dos meninos que estavam no corredor e os Muralhas também, aí atiraram pra dentro das celas a qual teve três mortes lá dentro, teve um que estava na capa, morreu com um tiro de fuzil, né? Morreu ele e mais um outro com uma bala só, é.... pessoas machucadas, foram mais 
de 18 pessoas machucadas, é..... e.... sem contar a agressão dos funcionários também, né? A qual que revoltaram mais os presos lá dentro, que teve pessoas, amigos nossos que estavam vivo e eles estavam ali futucando com ferro, enfiando ferro "morre agora seu P... seu Pececinho de merda" enfiando os ferros nos nossos amigos, nossos companheiros e nós vendo tudo.... a única coisa que é cruel, é cruel e ao mesmo tempo não é de 2 em 2 meses também por causa que tem o Choque, a revista do Choque, daí graças a Deus que não acontece mais nada porque vem uma pessoa dos Direitos Humanos junto...

V. Por causa do Carandiru?

D. Isso, porque daí o pessoal do Choque nem entra dentro dos barracos, só entra só os próprios funcionários, só entra só pra escolta. Daí o que acontece, daí bagunça, joga nossas coisas tudo no chão, vira o barraco de tudo, depois nós temos que levar tudo de volta. Daí..... nesse ataque que teve... desculpa tá falando assim, mas ...

V. Não, pode falar....

D. É que eu tô lembrando.... Então, o que acontece, nós ficamos mais ou menos uns 15 dias, 15, 20 dias depois desses atentados, a qual não entrava ninguém dentro da cadeia, amigos nossos passando mal, tendo ataque epilético, não tinha assistência nenhuma, não entrava nenhum, ao qual nós tinha que ficar batendo, sacudindo as grades, batendo garrafa no chão, toda a cadeia gritando, toda batendo, arrancando e vindo os Muralha e atirando pra cima de nós pra poder chamar atenção do diretor da cadeia. A comida chegava.... a gente ia pagar a alimentação é..... 5 horas da tarde o almoço, o café, o almoço e o café, nós já estava roxo de fome porque já tinha chegado o Choque já tinha arrastado tudo nosso, alimentação estragado que eles pisa é.... depende, também depende da situação, né? Pisam, chutam, estragam nossas coisas, então o que acontece, nós já estava varado de fome, tinha vezes que era meia noite e estava chegando a janta, às vezes chegava, como nós foi pro castigo eu cansei de ver, porque você tem acesso a primeira portaria, aonde que fica que chega o carro da alimentação, a firma contratada que coloca ali no carrinho e depois vai embora e ali a comida ficava por várias horas... é.... ficava ali na Radial debaixo do sol, às vezes chegava até meia morna e quando você ia pegar ela estava quente de tanto sol que já tinha ficado. E assim ia.... no castigo, demoravam pra servir a alimentação....

V. Você está falando de um desrespeito muito grande dentro da cadeia....

D. Isso... dentro da cadeia.... é.... policial, Agente Penitenciário que agride nós, é.... fala palavra até pras nossas visitas, cantam nossas visitas. Nossa... muito....

V. Vocês viam?

D. Não cê não via, mas chegava as visitas ficava atordoada, comentava, chorava e você lá dentro, você não podia fazer nada, a não ser se um dos Agentes, esses Agentes entrasse pra dentro e nós grudasse ele, é o único modo de nós defender e pedir pra dar algum direito pra nós. É..... o que acontece também, pra você adquirir, pra você fazer algum artesanato lá dentro é a maior burocracia, que você tem que mandar um bilhete pra diretoria, pra diretoria, pro diretor assinar pra você pegar uma carteirinha pra sua família começar a depositar é.... palito, palito de fósforo, palito de dente, é... cola, papel, palito de sorvete pra você fazer uns artesanato.

V. Não tem trabalho lá dentro?

D. Não tem trabalho, fica sem fazer nada o dia todo, no CDP, agora na Colônia, em Franco da Rocha tinha, eu não sei agora.... é tinha, tinha sala de artesanato, tinha sala de cabeleireiro, cabeleireiro lá só pode entrar uma maquininha no CDP, uma maquininha, um barbeiro responsável por cada $\mathrm{X}$, é uma maquininha e uma tesoura e.... assim.... você cortava cabelo lá, tudo, só tinha ele só, se ele saísse, daí você tinha 
que entrar em contato pra pedir uma carteirinha pra você estar adquirindo esses materiais, que é aquelas tesourinhas descartáveis praticamente, sem ponta, não corta nada e é só a maquininha mesmo e fora outros lugares, que nem tem um ... sempre quem manda os negócios pro PCC a maioria são os advogados que é um, que é todos, então o que acontece, eles trazem os estatutos, as coisas que aconteceu nas outras cadeias e eles falaram que ia virar por causa daqueles documentos, por causa que tinha cadeia que você ia, você era obrigado você cortar o cabelo careca, cortar o cabelo careca, você apanhava na hora que você entrava dentro da cadeia e apanhava quando você saía....

V. E aí vocês ficavam sabendo....

D. Ficavam sabendo por isso, por causa disso e também por causa do telefone, né? Tinha os contatos, daí nós fala, bom, nós vamos virar a cadeia, nós vamos parar, não vamos pegar bóia, comida, não vamos pegar nada, não vamos receber mais visitas, aquele negócio, a cadeia está parada, não sai fora, que nem aconteceu esses tempos, então é sempre assim, é sempre atrás de algum, algum benefício pros próprios pessoal que estão presos, uma reivindicação, entendeu? Não apoiando porque eles também fazem bastante, muitas coisas erradas..... Agora, também... o que eu tenho a dizer assim, que a minha vida, eu passei essas coisas tudo essa vez que eu fiquei abismado, coisas que eu nunca tinha visto da primeira vez eu vi dessa vez, né? É.... tinha viado morando conosco, travesti, né? Que eles moram separados, numa cama separada, não pode, que é ordem da cadeia, você não pode...., não dos policiais, dos agentes, dos próprios presos mesmo. Você não pode manter relação com.... relação homossexual dentro da cadeia, daí o que acontece, eles guardavam o nosso celular, guardava dentro deles, é.... eles guardavam drogas....

V. Quer dizer, eles recebiam pra isso....

D. Isso, e recebiam também por isso.

V. E não tinha ninguém que mantinha relação com eles?

D. Não, não pode.

V. Só entre eles?

D. Nem entre eles, não pode, não pode de jeito nenhum. Que é pra evitar, né? Por que senão vira bagunça e.... serviam pra isso. Então, o que acontece, vi bastante pessoas que estavam dentro da cadeia, que a qual são acusados, foram condenados já pelos crimes que não cometeram, que nem, estavam passando em frente a um lugar que mataram uma pessoa, só porque os dois eram pretos, os dois foram autuados, como se diz, em flagrante, como se tivesse matado a pessoa... aqui na V. A., tem outro menino que foi acusado de ter assaltado o Supermercado Andorinha e várias outras pessoas que... você vê lá dentro, né?

$\mathrm{V}$. E tem aquele processo que você tem que cumprir um tanto e depois você vai pro semi-aberto ou pra condicional, não sei se aconteceu com você? A pessoa já tá em condicional e continua lá dentro preso....

D. Isso, lá dentro continua, porque dentro do $\mathrm{CDP}$, lá não tem ninguém pra montar benefício pra você, o seu benefício só vai ser montado pra você realmente, se caso você receber... você está na cota, foi condenado 4 anos, nesses 4 anos você tem que tirar no mínimo 1 ano e meio, dois anos, pra você ganhar o semi-aberto. Então o que acontece? No CDP não tem isso, só se você for direto pro Fundão, que é a penitenciária mesmo, então o que acontece? Chegando lá, as coisas começam a andar mais rápido, porque tem o acesso da Funap, acesso de advogados que vão estar mexendo nisso, já montando o seu...

V. No CDP não tem isso por que? 
D. No CDP não sei...

V. Você foi pro Fundão?

D. Dessa vez não, que da primeira vez eu fui da 39 direto pra Colônia, por causa que como eu recebi o semi-aberto direto, eles não podem manter você preso no fechado ou em qualquer cadeia, porque se acontece alguma coisa, cai nas costas do diretor, mas tem muitas pessoas dentro do CDP também que foi condenado na Colônia e está ainda... 3, 4, 6 meses ainda lá dentro que não poderia estar, então lá o que acontece? Você só tem o benefício se você... é... é lento. Se você tem um advogado que você paga pra ele pra estar recorrendo, funciona, mas não é tão rápido que se você estivesse no Fundão.

V. Você tem idéia por quê?

D. Não tenho, que nem é.... essa vez eu fui condenado 2 anos em regime semiaberto...

V. Da primeira vez?

D. Dessa segunda vez, daí o que acontece... o advogado meu foi do Estado, tudo, que eu não tinha dinheiro pra estar pagando, daí, como eu não sei o que ele pediu, o que ele entrou, daí mandaram eu pra rua, pra mim é... fui condenado 2 anos de semiaberto, mas pra mim apelar ele, me mandaram pra rua, em vez de me mandar pra Colônia, me mandaram pra rua, a qual eu estou em apelação ainda... Isso, já entrei com apelação, só estou esperando a sentença, né?

V. Isso significa que você nem está em Condicional, nem tem que se apresentar em juiz, nada....

D. Não, estou aguardando sentença, a qualquer hora eu posso ser condenado e ter que voltar pra cadeia, ou receber pra mim pagar em cesta básica, ou serviço comunitário, ou é.... ficar assinando carteirinha no Fórum.

V. Que é a Condicional...

D. Isso...

V. Então nessa você não consegue nem trabalhar, por exemplo, atualmente...

D. Atualmente eu consigo porque eu conheci um rapaz que estava preso comigo, né? Que ele tem uma concessionária de carro e uma funilaria, ao qual ele estava tirando o carro... colocaram um carro batido dentro da funilaria dele pra ele arrumar e quando ele estava colocando o carro pra fora, as polícia veio, abordaram ele falando que o carro era roubado, daí levaram ele preso como 180, daí saiu, ele foi lá, que chamam de apelido, né? Daí ele me chamou, "ô J. quando você sair daqui, eu quero, não quero ver você roubando, você aprontando mais, você vai trabalhar comigo". E graças a Deus, Deus colocou ele no meu caminho pra estar ajudando.... Eu trabalho direto com ele, daí... trabalho de sexta-feira num baile que ele dá, na Celso Garcia, que é um baile da Nostalgia, pra terceira idade, que eu trabalho como copeiro e bar man e.... casei, hoje tenho minha filha, tudo... voltei com a minha mulher, minha mulher que tem uma filha com ela, então hoje em dia a minha vida é essa, eu trabalho, tô agitando, esperando ajeitar esses negócio pra mim voltar a estudar....

V. Porque nessa situação você não consegue nem matrícula?

D. Nem matrícula, você não consegue nada....

V. Você não tem documentação?

D. Não tenho documentação...

V. O seu RG tá preso?

D. Não, o RG quando você sai, você recebe, mas... eles sempre pede a ficha criminal, né? Consta como que se você tá..... vamos dizer como se você está preso ainda, né? Você está devendo ainda alguma coisa. Então você não consegue, pela 
discriminação, a qual, hoje em dia, tem muitas pessoas que estão entrando na marginalidade ou continuam por falta de oportunidades...

V. Isso que eu queria te perguntar, o que você acha que leva uma pessoa, o que leva um garoto de 14, 15 anos como você começou a entrar nessa vida, o que você acha que leva? O que você pensou na época?

D. Ah, tipo assim, você.... você é um adolescente, você vê seus amigos de roupas novas, você vê seus amigos de moto, tendo dinheiro pra sair com namoradas, esses negócios, e você... e você sempre quando você tem, se vai num lugar, se você tem uma calça você não tem um tênis, então você vai num lugar você é tirado sarro, os próprios amigos, às vezes até primo, parentes também que tem alguma coisa e não ajudam, então o que acontece, você pede uma ajuda pra uma pessoa pra você não entrar e às vezes por conseqüências da vida, você acaba entrando nessa, nessa vida, não... uma coisa, vamos se dizer, te obriga, você olha ali, você, você procura arrumar um serviço, uma coisa, mas você não consegue, por causa que.... hoje em dia, se você tiver idade demais você não arruma mais serviço e se você tem a idade, pede a experiência, como você? Você acaba de fazer um curso disso, mas como que você vai ter um ano de experiência e carteira assinada, sendo que ninguém te dá uma oportunidade, então o que acontece, daí você olha ali, você vê um cara ali que tava roubando, vendendo droga e sempre com dinheiro, sempre com ....

V. Você vê isso o tempo todo? Você via isso?

D. O tempo todo, ainda vejo porque ainda conheço, hoje eles no lugar dele e eu no meu lugar, cumprimento, tudo.... então você vê com carro do ano, com moto do ano, roupa de marca, então você ficava assim, "pô mano, porque... é o seguinte, vou pedir uma chance pra minha mãe, se ela me der a moto e eu começar a trabalhar, é um dinheiro a mais, né"? Daí o que acontece, como negaram pra mim essa oportunidade, falei... daí eu vim, continuei roubando no 155, né? Roubava objetos, mercadorias, invadia supermercados, arrancava tudo, roubava, colocava numa casa que nós tinha alugada, guardava os produto de furto, depois vendia, pagava aluguel, comprava é.... coisas pra nós, roupa, passeio, esses negócio, era só pra isso. Daí depois disso que nós fomos confundidos com esses rapaz do PCC, esses ladrão aí, daí o que acontece? Que nós mudamos totalmente a nossa mente: "Agora nós vamos roubar mesmo de mão armada e se vier alguém nós vamos mandar bala pra cima". A vida acaba criando você desse jeito, a rua, entendeu? Às vezes, um adolescente, o que ele quer, ele quer um pouco de atenção, se você que nem... nessa época, tudo, eu vendi drogas também na rua, tinha biqueira que (...) mesmo tendo meu próprio ponto, então o que acontece, é.... às vezes chega um adolescente que você.... chega ali ele está com problema dentro de casa e às vezes o que ele recebe mais um carinho, um conforto é do cara que tá na biqueira, que está ali na droga, então o que acontece, chega ali "não, o que foi, senta, vamos conversar, não, mas isso é coisa que acontece..." sempre está colocando a pessoa pra frente e vai puxando mais a juventude pro lado dele.

V. Você tinha quantos anos mais ou menos?

D. Eu tinha a faixa de 16 a 17 anos.

V. Estava na escola?

D. Não, já tinha saído da escola.

V. Por que você saiu?

D. Porque eu era.... vamos se dizer assim, eu era a criança problemática, né? Chegava as molecadas, falava coisa pra mim e eu batia neles... é..... eu era ignorante, era traste ruim como que dizem os baianos, então o que acontece, daí batia, quebrava 
vidro da escola é.... pichava... é.... tinha época de gang também, de pichação, daí o que acontece? Sempre arrumei encrenca dentro de escola e não prestava muita atenção na aula, queria mais namorar, não prestava atenção, fugia de casa às $11 \mathrm{~h}$ da manh... da noite pra ir pro salão na sexta-feira com 11 anos de idade e assim foi indo, minha vida sempre foi nessa, nesse... nesse seguido, né? Daí o que acontece? Eu ia pra escola, tudo, mas não prestava atenção, daí teve umas... é... umas psicólogas que... esses negócio de escola, daí fez um.... psicologia, um negócio comigo, uma consulta comigo, daí falou pra minha mãe que eu precisava de mais atenção, que eu tinha que ficar em sala particular....

V. Tipo especial, como assim?

D. Isso, sala especial....

V. Isso você tinha quantos anos?

D. Eu tinha uns .... 10 anos, uns 10 não, uns 10, 11 anos...

V. Você sabia ler e escrever nessa época?

D. Sabia mais ou menos... Daí minha mãe falou "não, vão te colocar numa sala especial, só que é dois meses", só que quando eu fiquei sabendo a real que eu tinha que fazer 2 anos pra completar um ano nessa coisa e eu tinha que ficar com pessoas que era.... doentes mentais, que tinha problema de fala, com síndrome.... não que eu tenha algum preconceito com isso, que nessa época até namorei com uma menina que tinha problema assim, né? Que não escutava direito.... então o que acontece, só que aí eu fui ficando ali, até peguei um pouco de gagueira por causa disso aí... então quando eu fiquei sabendo a real eu não aceitei, falei não, a senhora falou que era dois meses, agora tem que ficar 2 anos pra completar um ano, que não sei que... daí não fui mais pra escola, me mandavam pra escola, tudo, eu ia, mas em vez de eu ir pra Santana, que eu estudava em Santana no T B, daí eu passava por baixo do ônibus, daí gastava meu dinheiro de condução nos fliperama, no shopping e voltava... como se tivesse ido pra escola, daí ficava aqui no Mutirão e do Mutirão eu ia pra casa...

V. Tá... e a sua mãe sempre trabalhou? O que ela faz?

D. Minha mãe sempre trabalhou, ela é funcionária pública, ela tira carteira de trabalho, trabalha na ....

V. E você tem quantos irmãos?

D. Tenho 3 irmãos, eu sou o caçula, isso.

V. E os outros são casados, têm filhos?

D. Os outros são casados.

V. Alguém passou pela mesma experiência que você? Ninguém foi preso? Ninguém passou pela Febem?

D. Não, não...

V. Aliás por falar em Febem o que você acha que aconteceu que você não foi pego antes dos 18 anos?

D. Ninguém me pegou....

V. Nunca foi parado? Nada?

D. Sempre fui enquadrado, apanhei de polícia tudo... mas nunca fui preso nessa época, nunca fui autuado, só depois quando fiz, estava com 20 anos pra 21 que fui preso a primeira vez.

V. Você já ouviu falar que eles querem fazer uma redução da idade penal? Já ouviu falar disso?

D. Já, que em vez da pessoa ser presa aos 18, passa pra 16 anos.

V. O que você pensa disso? 
D. Em parte eu vou falar que é uma... é uma... boa, mas hoje em dia, é.... tem que ver mesmo porque tem.... hoje em dia são muitos jovens que estão indo pra cadeia por delitos, sabe? Que não tem cabimento, coisa leve.... Tipo tem jovens hoje em dia que eu conheço, aqui até do bairro, que foi roubar comida, né? e tem pessoas assim até... às vezes você chega, você é uma pessoa mal vestida, de mal aparência, que chega as pessoas já estão com medo, então o que acontece, tem pessoas inocentes, jovens inocentes que estão acabando sendo prejudicados com isso, que eu acho que até os seus 16 anos, 17 anos tem muito adolescente que ainda não sabe o que faz, tem influência, influenciado por outros, pelos amigos, tipo, vai lá, nós dois, nós consegue, nós tamo sem dinheiro pra ir pra festa, pro baile, vamos lá catar não sei que ali que é fácil, né? Então são sentenças assim que você... você tem que pagar ali pelo que você fez, mas são coisas de Febem, esquema de Febem, o que acontece, são... tem que colocar um fundamento pra aquelas criança ali que tá.... eu falo criança, mas tem cada marmanjão que está ali, maior do que eu, mas o que vai mudar a mente deles, se você pegar um cachorro, um Pitt Bull e você criar ele pra atacar, qual vai ser a função dele? Ele vai atacar, agora se você pegar um Pitt Bull e criar ele como um vira-lata, cê vai entrar um ladrão dentro da sua casa, tudo, ele vai lamber a mão do ladrão, né? Vai lamber a mão dele, então você vê, o que acontece, o modo de tratar, né? Que nem esse meu parceiro que foi preso a primeira vez, ele foi pra Febem, ele era menor, então eu conversei com ele e.... tem muitas coisas ali que... você está assistindo, eles coloca a televisão lá pra você assistir, que é 1 hora, 2 horas de televisão, só que você tem que ficar lá sentado em posição, com as pernas juntas, cruzado, né? E de cabeça baixa, você não pode nem vê a televisão, se você vê você apanha é..... o que acontece? Você ali tem coisas que é cortado, tipo tem... é vício, né fazer o que? Tem jovens que fumam, lá você pode pegar uma, um maço de cigarros pra dividir pra todo mundo e tem que durar até o próximo, até o outro dia, que acontece, um cigarro pra cada um e quem fuma, eu fumo mesmo, quem vai falar que consegue ficar um dia.... você fica desesperado, atordoado, então com agressão com tudo, então nisso mesmo que eles vão quebrar, vão quebrar a cadeia, vão grudar os funcionários, que nem lá no Belém que nós foi virar alguma coisa, a cadeia, que nem nós viramos na 39 também, nós avisava é... tinha funcionário que nós falava, “ó, amanhã é seu plantão, nem aparece que amanhã nós vamos virar a cadeia e dependendo quem tiver aqui nós vamos grudar".

V. O pessoal que vocês achavam bacana vocês avisavam?

D. Isso, nós avisava, pra não ter nada, nada acontecer com eles, né? Tem funcionários ali que trata você como gente, agora tem outros que trata você pior do que um cachorro, do que um bicho, então isso que acontece, acontece muito na molecada, na juventude e a juventude hoje em dia que ela quer ser mais malandra, né? Como diz malandro, mais criminoso do que aqueles que estão lá dentro, que tem mais idade e que já passaram por outras coisas, os mais jovens querem ser mais do que os maiores...

V. Por que será?

D. Pra demonstrar, que é como se diz que eles são é.... periculoso, periculoso tipo, nós é.... nós é.... é, como que eles falam lá dentro? Nós é treinado pela Al Qaeda, nós é terrorista, eles falam na cadeia, treinados pela $\mathrm{Al}$ Qaeda... então são isso, são coisas que acontece... é.... você na rua, você vai aprendendo, você vai olhando, você vai conhecendo esses negócio, você entendeu?

V. Você tem uma filha, né? Como que você vai criar essa filha, como que você pensa? 
D. É agora, que agora eu tô trabalhando, né? E que eu peço a Deus pra não ser condenado pra ter que voltar pra cadeia....

V. Quando ela tiver lá pelos seus...

D. 14,15 anos...

V. É, como cê acha que vai ser?

D. Ah, eu vou ser sincero, eu vou explicar a minha vida todinha pra ela, vou falar que eu fui preso, vou falar que eu já andei com arma, vou falar tudo, não vou mentir, tudo, pra que um dia, pra ela pensar e falar ó, vir um rapaz, um adolescente, vir do lado dela e oferecer um cigarro, um baseado pra ela, ela falar, "não, calma aí eu não vou fumar porque meu pai já fumou, ele falou que é assim, assim, assim, vai atraindo isso, isso, isso", então pra você ter um conhecimento, hoje em dia o que falta é muitos pais sentar com seus filhos e conversar.... existe droga, é assim, assim, assim, existe sexo, só que você tem que usar camisinha, tem que fazer assim... então....

V. Falta conversa?

D. Falta conversa entre os pais, hoje em dia tem mais pessoas é.... assim... que não é da família, pessoas assim que dão uma explicação pra nós, que nós precisava ouvir do que, dos nossos pais, das nossas mães, que mulher você recebe mais é... da tua.... conversam mais com a mãe, né? Agora o filho não, você tem que sentar, você tem que explicar, o meio da marginalidade é aquilo, só tem dois fundamentos, cadeia ou cemitério, "ó eu fui preso, passei por isso, isso, isso, dentro da cadeia, você quer isso pra você? Não quer, então vamos estudar pra ser o que eu não fui”, sempre você influenciando a vida da pessoa. Mostrar o que é a vida

V. Se alguém tivesse feito isso com você?

D. É... talvez eu não teria.... acontecido tudo o que aconteceu comigo hoje em dia, que nem hoje em dia eu sento com as minhas sobrinhas, tudo, converso com elas, tem as minhas sobrinhas que tem, a mais velha tem 15 , converso com elas tudo, explico o que é.... o que é camisinha, o que é relação.... eu faço isso porque minha cunhada não tem aquela coragem, meu irmão trabalha muito e de vez em quando chega e bebe, né? Daí já chega, toma banho, deita e dorme pra ir trabalhar no outro dia. Meu outro irmão mais velho só.... Deus que guarda ele, né? Que é viciado, é viciado também ele....

V. Em bebida?

D. Também, bebida.... em.... crack, em.... cocaína, esses negócio, então o que acontece? Então fica aquele ambiente, então você tem que explicar pra você.... pra sempre saber que vai correr no jeito certo, nunca vai aprontar, nunca vai dar trabalho, você entendeu?

V. Tem que ter muito diálogo?

D. Tem que ter muito diálogo.... hoje em dia também os professores.... hoje em dia, que falta mais o diálogo, carinho do professor, porque hoje tem muitos professor que tá na escola, dá aula tudo, mas não tem aquele carinho, "há, não vou dar aulas pra estes pestes aí tudo, daí já sei que no final do mês eu tenho o meu e já era!" Tem que ter mais carinho, amizade, você vê que aquela criança está tendo problema dentro de casa, né? Que você percebe, então você tentar adquirir aquela criança pra você, ela sempre está ali, não, se sentir querida, pelo menos por alguém, daí é isso.....

V. Que não seja pai e mãe, mas como no seu caso, você como tio está tentando fazer....

D. Isso... isso... tô explicando, tudo, pra que se um dia, se querer aprontar, fazer alguma coisa assim, você já sabe que você incentivou, você deu o passo pra ela 
seguir o caminho bom, né? Que não foi por falta de palavra ou falta de diálogo, porque quis mesmo, né?

V. Existe isso da pessoa... tem alguém incentivando, falando as coisas bacanas, mas a pessoa quer porque quer e acaba indo do outro lado?

D. É... tem muitos....

V. O que você acha que acontece que leva a pessoa a isso?

D. Hoje em dia tem muitos jovens, muitas pessoas assim que vão, né? Pro mundo do crime por causa da precisão, porque precisam...

V. De comer ou precisa de roupas, essas coisas?

D. De comer, de roupa, de dinheiro pra poder se manter, né? E também hoje em dia tem muitos jovens, adolescentes, que vão pelos outros... "ah aquele ali é bandidão, aquele ali já tirou tantos dias na cadeia, aquele tem uma biqueira ali, é isso assim, assim, assim, né"? Então o que acontece? Eu vou andar do lado dele.... então pra você andar do lado dele.... pra se sentir.... como se fosse uma pessoa da mídia, então falam isso pra molecada.... "ah, eu ando com tal irmão assim, assim, assim, ah eu faço umas corridas ali também, que não sei que..."

V. Isso valoriza as pessoas?

D. É, pra eles! Pra mim não valoriza ninguém, mas pra muitas pessoas.... é mais no meio da juventude, da molecada, é pra eles "nossa, você anda com tal!" Então pra muitos é até vangloriando, é como se fosse um deus....

V. E me diz uma coisa, o que você acha que fez você desistir disso? Querer trabalhar, criar sua filha?

D. Uma também foi depois dessa Mega de 2006.... eu vi coisa que foi terrível.... é os Faxina com pano na cara, com faca que nós mesmos teve... que nós mesmo amolamos pra poder grudar os funcionários é.... Muralha atirando de (...) de fuzil pra cima de nós, amigos nosso perdeu metade de mão, perdeu dedo, tomou tiro, é... ficou por lá na enfermaria porque não saíram de dentro, não foram pra hospital nem nada, só sai se você estiver realmente morto, que nem, eu tenho um problema no pé, né? Aqui o pé quebrado, só que eu não ajeitei ele direito, então ele dói, que é fora do lugar, pra você fazer tratamento, não tem como, você fica do jeito que você está mesmo... eles te dão um remédio, mas uns remédio mixuruca, né? Vai a..... como que é o nome? O pessoal que é de... de.... Igreja, que faz é..... coisas lá nas cadeias? Esqueci o nome.... eles estão na igreja católica, que eles põe o pessoal pra isso, daí vão lá, levam o crucifixo pra nós, rezam, lê a palavra... esses negócio.... a qual é respeitado qualquer tipo de igreja e a cadeia.... a cadeia hoje em dia são variados, tem dois tipos de cadeia.... que tem a cadeia do Comando, né? Do PCC e tem a cadeia da oposição que é o CRBC, é.... Serpente Negra.... São vários outras cadeias.... O que acontece, a cadeia do Comando ela é.... através dela... ela prova, que hoje em dia tem uma lei que o preso tem o direito de fugir, mas cada tentativa de fuga, também, o Muralha tem o direito de tentar atirar em nós, matar nós. Então o que acontece? É uma lei que tem, né? O direito, o preso tem direito à fuga, mas também os Muralha tem o direito de... né? Então, o que acontece? Então a cadeia do Comando ela aceita o negócio, você juntar o pessoal, vamos abrir um buraco ali, vamos tentar fugir, vamos quebrar a cadeia, vamos fugir e.... a cadeia da oposição , do CRBC, que é a...... a $9^{\mathrm{a}}$, a $10^{\mathrm{a}} \ldots$. a $10^{\mathrm{a}}$ é a cadeia de oposição, hoje em dia não sei porque não tem mais cadeia, né? É só CDP, então o que acontece, eles já não aceitam a fuga, e essa cadeia é de oposição, então o que acontece? É na onde que pode estuprador, onde que tá pessoa... cara que mata.... que nem o assassinato do menino João Hélio, esse pessoal que matou essa criança, eles não entram na cadeia do Comando, ele não entra 
lá dentro, se ele entrar eles ali pede a cabeça, ele morre lá dentro, então já tem a cadeia própria pra eles, ou senão já vai pra lá, mas já pede pra ir pro seguro.....

V. Os juízes sabem disso?

D. Sabem...

V. Tem acordo entre esse pessoal do Comando e os juízes?

D. Ah tem, tem, tem.... o juiz hoje em dia... é.... se você tiver dinheiro mesmo, você sai da cadeia.... se você não tiver.... que nem, no dia que eu fui preso na 20 , teve um rapaz que foi preso num... numa mansão, que ele é ladrão de mansão, então o que acontece? Eles foram presos dentro da casa, né? Com dinheiro, com tudo e com armamento, com 2 revólveres, daí o que acontece? Chegou lá os ladrões ofereceram um dinheiro para liberar eles, 50 mil reais, daí falou não, por esse preço nós tira a arma e tira as mercadorias, fica como tentativa de 155, daí firmeza, fizeram um acordo, daí chegou na 72 e ele falou "e aí, tem como fazer um acerto pra soltar nós?" Daí o carcereiro, o policial lá falou "é o seguinte, se você tiver 200 mil aí, você sai agora", daí ele falou "eh, cê tá é tirando, se quiser eu te dou 200 real, já tô fichado mesmo, vou ficar como fugitivo", daí ele falou "não, cê me dá 70 mil e você vai embora agora, já te dou, pego até o telefone lá na frente pra você ligar pro seu advogado vir trazer o dinheiro", daí não sei o que foi lá que daí não soltaram o dinheiro. Tem esse advogado deles que esse ladrão conhece desembargador, juiz, esses negócio, então né? Taí, já tá até pra sair pra rua já, então o que acontece, hoje em dia, o que você tiver dinheiro é o que manda, apesar que tem muitas vara criminal que o juiz é vara ruim de roer... ele não libera, não libera e mesmo se você, mesmo se for uma coisa simples eles não tão aí, tão aceitando aço, o aço que a gente fala é mandando pancada, né? Um montão de cadeia, que nem, essa vez, essa vez agora eu fui julgado pela $3^{\mathrm{a}}$ vara a.... pode falar o nome da juíza? A Dra. $\mathrm{X}$, da $\mathrm{N}^{\mathrm{a}}$ vara, essa mulher, misericórdia, é uma cobra, orra, partindo do advogado do meu primo que foi particular, só depois foi do Estado, e disse que ela não queria soltar ninguém e como pra quebrar a formação de quadrilha eu tive que segurar a queixa...

V. Sozinho? E os outros?

D. Sozinho, os outros tá pra sair, pra sair livres por causa do que? Porque ..... eu como já era condenado e estava em regime semi-aberto, assinando carteirinha, então o que acontece? Se eu segurasse 157 e a formação de quadrilha, o mínimo da formação de quadrilha é 8 anos e 157 é sempre 4, então eu ia pegar um montão, né? Então aí nós comentamos, tudo, aí como eles não queriam segurar, então falei, vou ter que segurar eu mesmo...

V. Porque pra você ia ser mais prejudicial....

D. Isso, mais prejudicial porque eu estava respondendo, ia fechar minha cadeia, né? Que eu ia ter que voltar no fechado pra matar os outros 10 meses, por aí que faltava e depois responder o outro artigo, daí o que acontece, daí eu ganhei o semi-aberto, daí já mandaram direto pra rua, e.... que mais que eu ia falar... daí é isso...... estuprador, essas pessoas, elas não entram pra dentro da cadeia, não entra, é proibido, então quando você sai do RO você sai direto pra Faxina, pra Faxina ou pro Esporte, onde que ficam os irmão do PCC, aí pergunta, você tem alguma encrenca com o PCC, com o Comando... é .... qual o seu artigo, esses negócio, daí firmeza, daí eles vão lá fala você tem, quando você está no RO também, quem ajuda você mesmo são os próprios presos também, que você está no RO, então o que acontece, eles não podem vender nada pra você e você não pode comprar nada, é tudo doado, é sabonete, papel higiênico, é... às vezes chega um conhecido nosso, daí te dá uma toalha, dá um cobertor é.... a única coisa precária lá é o colchão, que tem uns colchão que é 
horrível, cheio de buraco, todo rasgado é... coberta, que eles não dão, é.... tem pessoas que... você que tem que ver... você vai saindo embora da cadeia, você vai deixando suas coisas pra outros, né? Tem pessoa que não tem visita, que ela é descalço, chinelo é todo remendado, então você vai doando... no RO você dá coberta, você dá o que tem, chega comida, né? Que é a comida mesmo no dia da visita, acaba a visita, nós separa e manda pro $\mathrm{RO}$, é o próprio preso que dá assistência pro novato. A única coisa que a cadeia, o CDP oferece pro ladrão é a parte da alimentação, que de vez em quando vem uns cardápios que são bons, tem vezes que tem cardápio que é horrível a comida.... que nem tem vezes que eles dão é... variado a mistura, às vezes eles dão arroz, feijão, ovo cozido e grão de bico, daí tem vez que eles dão arroz com purê de chuchu, com bisteca, às vezes dão um steak que parece uma sola de sapato... e é assim, né? A bisteca em vez de ser frita parece que ela é cozida, parece que eles colocam um monte, sabe quando você coloca um pouco de óleo, bastante óleo que você coloca um monte de carne, em vez de fritar ela cozinha? É.... é igualzinho e.... sem contar que às vezes você acha cabelo, às vezes você acha unha e.... de tarde chega um pão, chama o Marrocos, dão pão, o suco que é o barraqueiro que faz, agora o açúcar é nosso, se você tiver açúcar você toma suco doce, se você não tiver você pede nos outros barracos, se os outros barracos não tiver aí você toma suco sem açúcar (risos) e assim é, né? Às 7 horas da manhã vem o contor pra contar, todo dia... daí depois vem 2 horas da tarde conta.... não! Vem 7 horas da manhã, cinco horas da tarde..... que nós..... abre a tranca 8 horas da manhã e fica até às 4 horas da tarde....

V. Pode circular?

D. No pátio, só no pátio. O único que tem.... pra circular em qualquer raio, qualquer rua, é o irmão piloto da cadeia, ele tem direito pra subir até lá em cima pra falar com o diretor, daí o que acontece? Fica no pátio, vai jogar uma bola, né? Que as bolas é compradas com o nosso dinheiro também, que nós pede pra visita trazer é..... faz musculação que nós pega 2 cabos de vassoura, coloca garrafa d'água cheia de água de 2 litros e faz peso, é.... sabão em pó eles dão também, a cadeia, cândida esses negócio, mas sabão em pó é aquele que não vale nada, daí limpa toda sexta-feira, que nós limpa a cadeia todinha que é pra visita no outro dia chegar e está limpo, pra poder a higiene, que é uma higiene tremenda lá dentro, daí o que acontece? Nós lava a cadeia, lava o banheiro lá dentro, a cela, quem tem visita fica lá dentro com a sua visita tendo a sua íntima, né? Isso, daí tem as burras e coloca os cordão, né? Amarrado, coloca 2 lençóis na frente e...... cada visita por cama... são três camas aqui e são três pessoas que tira visita aqui e mais três aqui, três aqui e duas aqui, não uma aqui que uma é liberado para colocar as Tuperware da barraca e a outra é a barraca, a comida, então cada uma tem dois panos, um cortinão, são 2 panos tampando pra você ter sua visita e quando às vezes tem mais gente, daí é meia hora de cada um, daí sai da burra, o outro sobe, estende seu lençol e aí tem sua íntima....

V. Sua mulher ia te visitar?

D. Não, eu estava terminado com ela, tinha terminado, brigado, quando eu saí da cadeia eu voltei com ela e hoje em dia graças a Deus nós estamos bem, estamos melhor que antigamente.

V. Quando você cometeu as infrações você morava com sua mãe e seus irmãos?

D. Isso....

V. E sua mãe que sustentava a casa?

D. Isso, minha mãe que sustentava a casa, e minhas 2 cunhadas, daí tinha um irmão meu que é casado que morava embaixo e tinha outro que morava com a minha mãe, 
que é o que até hoje mora com a minha mãe e tinha um outro que morava comigo, que cada um tinha seu espaço em casa, no mesmo quintal...

V. E você tem uma filha só?

D. Eu tenho uma.... que é a consideração, né? Que é a filha da minha mulher com outra pessoa e tenho uma que eu nunca vi, é com uma outra menina que é a R., hoje em dia ela deve ter uns 7 anos, 7 ou 8, que eu nunca vi que ela fugiu com a nenê... por causa que quando eu trabalhava, tudo, era um moleque decente, né? Então o que acontece? A família dela.... enquanto eu ajudava a família dela eu prestava, daí eu não fazia compra pra casa dela, fazia pra minha casa que eu moro... morava no quartinho com o meu irmão, daí eu não prestava, quando eu ajudava eu prestava, quando eu não ajudava não prestava, daí ela terminava e voltava, terminava e voltava.... eu cansei e terminei de vez... daí ela pediu pra voltar comigo e eu falei "não, não gosto mais de você", só que eu não sabia que ela estava grávida, daí ela fugiu com a criança na barriga... nunca vi.... nem registrei, só sei por causa da família deles, tudo, mas não me falam de paradeiro, não me falam de nada, hoje em dia sei que outro rapaz registrou ela, assumiu a criança e dizem parece que ele é ladrão também, essas coisa e também que se eu fosse lá ele ia me matar, daí eu ia até cobrar, como que eles dizem, cobrar essa fita, eu ia lá, né? Mas deixei quieto, pra lá... foi quando eu comecei a pôr umas coisas na cabeça....

V. Você nem anda mais com arma?

D. Não, nem gosto, quer ser meu amigo não me chama pra roubar, não me chama pra nada, passo, cumprimento, e...

V. Foi o fato de ter visto aquele monte de coisa que fez você pensar....

D. Foi também.... o fato também da primeira vez minha mãe teve uns problemas tudo, da primeira vez minha mãe teve um aneurisma cerebral, né? Um derrame... nervoso, né? Porque.... eu preso e ela com problema no serviço.... problemas com meu padrasto é.... ajuntou com emoção boa que foi o casamento do meu irmão, ajuntou tudo isso, aí ela teve um AVC, né? Aí eu estava preso ainda na Colônia de Franco da Rocha, então daí por causa disso, por causa da minha mulher, a família da minha sogra, minha sogra, meu sogro, que até um tempo não gostava de mim e agora tão vendo que eu estou mudando, até chamei meu sogro também pra trabalhar comigo, que arrumei serviço pro meu sogro, então viu que eu estou querendo um objetivo mesmo meu, então hoje em dia mesmo eu mudando meu jeito de ser, meu modo de andar, meu modo de viver, mas tem muita.... como que eu chamo.... é..... pessoas é... julgam, ó lá, tá preso, foi preso... tem muita gente, muitas pessoas, tem mãe de amigos meu que não quer ver eles conversando comigo é.... até eu voltei porque quando veio o oficial de justiça na minha casa, liguei pro advogado que é amigo da família da minha esposa, a qual ele saiu falando pra todo mundo que eu era ex-presidiário, que não sei que, que até a família da minha esposa, da mãe, da prima do esposo dela, né? Da minha sogra falou que não quer que eu vou lá de jeito nenhum, até minha sogra e meu sogro fica.... é.... como que se diz? É..... processar o advogado que ele saiu falando pra todo mundo.... eu falei que não, não quero saber de mais nada disso, nem negócio de ir no fórum não quero mais saber, então ela falou "não, você tem que processar...." Tá bom, se vocês quiser processar vocês corre atrás de advogado, tudo... que isso daí, falei, isso daí tem muito... que muitos lugares que eu vou tem amigos que eu conheço, que por sinal hoje em dia eu nem falo, nem tento lembrar, nem lembro do meu passado... falam ah você viu, não sei que.... aquele ladrão ali.... misericórdia, não gosto nem de passar nessas ruas, já dou uma de 
nunca foi pego, nem conheço... mas hoje em dia é assim que eu vou levando a minha vida assim, desse jeito....

V. Você parou de estudar, né? Que série você parou?

D. Parei na terceira série.... e hoje em dia eu estou esperando porque eu não posso passar né? Eu não sei, né? Que uns falam que eu não posso passar das 10 na rua... e hoje pra mim voltar a estudar, então o que acontece... é só à noite e se eu vou, então como que é? Você que já teve processo na justiça, você está vindo da escola ou de qualquer outro lugar, se o policial ele te para, se ele for com a sua cara ele só puxa o seu documento vê que você não tem nada, que você está limpo, que você está chegando de algum lugar, do serviço, eles vão e te solta, agora se eles não vão com a sua cara, eles mesmos jogam drogas no seu bolso, eles mesmo te prende por coisa que não tem nada a ver... isso.... que nem tem muitos hoje em dia, policiais andam com drogas, passam em biqueira, né? Que chamam de biqueira, chega lá apreende as drogas, não prende os caras porque usam.... tem vez que tem, você vê policial que está mons... monstruado, né? Que tá doidão, entendeu? Conheço amigo meu, policial também que fala "nossa, tem vez que os caras aqui, que eu tô lá, levam lá pra ..... pra C., nós corta os caras na bala, aí falam bem assim mesmo!" Que nem, isso eu escutei no próprio radinho, um amigo meu que tem os conhecimento com os polícia, né? Não é ladrão nem nada, aí eu escuto o pessoal falando pra ele no radinho "ó mano, você fica no gelo, não anda ali pelos $\mathrm{F}$. da T. entre a rua 9, o barzinho da rua 9 e a rua 10, nenhuma lojinha, fala pra fechar tudo, porque se nós tromba alguém na rua nós vamos assassinar"!

V. No Ratinho isso?

D. Não, pelo rádio que fica viva voz, tipo celular mesmo... então é assim, hoje em dia, polícia também que fala... vem ficar com o pessoal, que nem aqui já aconteceu na rua, que eu conheço, com droga, fala "ó, pra nós te soltar nós quer $10 \mathrm{mil}, 5 \mathrm{mil}, 7$ mil", teve a vez do meu primo que não tinha nada a ver com crime nenhum... é.... pra ele sair da rua que quando mataram um policial, atiraram num policial, aí prenderam ele, falou que se ele não pagasse 7 mil que eles iam jogar esse crime nas costas dele... e teve que pagar, né? A situação é... sujeita, eles pedia tem que pagar e que eles às vezes você paga, cê pensa que está firmão e eles tão aí cada vez querendo mais, isso.... a corrupção é muito grande, uma corrupção muito grande....

$\mathrm{V}$. Acho que da minha parte é isso, você queria me contar mais alguma coisa?

D. É só isso então.... qualquer coisa cê fala com a tia Elaine e eu respondo mais coisa....

V. E me diz uma coisa, quando você falou que os caras deram uma "boca" pra você cuidar, você foi, chegou a .....

D. Cheguei.... era aqui na rua debaixo o meu ponto, naonde que eu vendia droga pra mim mesmo, daí vendia um dia maconha, haxixe é... farinha....

V. Quem fornecia pra você?

D. Nós comprava mesmo, tinha os fornecedores lá do Paraguai e nós contratava jovens, pessoas de menor, pra tá indo pro Paraguai pra trazerem droga pra nós, aí nós pagava pra eles....

V. Por essa você nunca foi pego?

D. Dessa não...

V. Você teve sorte, hein?

D. Graças a Deus.... então hoje em dia, que nem todo mundo fala "nossa D. você tem 23 anos...." hoje em dia eu tenho 23 anos, fiz agora dia 31 de dezembro, fala "nossa, você já viveu muitas... poucas e boas, dá até pra você escrever um livro!" Que... eu 
curtia rock também.... a qual eu comecei a usar droga depois que eu comecei curtir rock, que eu curtia som gótico, ia pra cemitério, dormia dentro de cemitério, com gangs, né? Que era os góticos, tinha punk do lado, skinhead.... batia, dava facada, esses negócios tudo....

V. Começou aí?

D. Começou aí....

V. Tinha quantos anos?

D. Nessa parte eu tinha uns 14 anos, 14 pra 15 anos...

V. Sua mãe deixava você ficar fora de casa assim?

D. Ah.... não tinha.... não tinha mais um..... como ela falava, "não faz isso" eu chegava e falava "vou aqui no supermercado, né?" encontrava com uns amigos meus nesse supermercado e eu ficava 3, 4 dias sem aparecer dentro de casa... eu andava todo de preto, de coturno, calça rasgada, ia pra cemitério, voltava, maquiagem na cara, batom preto, esses negócio tudo e voltava depois de 4 dias... Quando eu falava ah, vou ficar uns 15, 20 dias eu ficava uns 6,7 meses sem aparecer em casa, eu sempre sumia, desaparecia sempre, daí comecei a frequentar, a fazer delito, 155 e assim foi indo.... foi crescendo... e chega uma hora que a juventude fala é o seguinte "chega, quero alguma coisa que ou me dá dinheiro mesmo ou... né?" Alguma coisa assim.... Hoje em dia eu me arrependo mesmo do que eu fiz, do que eu deixei de fazer, né? Me arrependo muito, agradeço as pessoas que me ajudaram bastante: a tia Elaine, a tia Fabiana que era monitora também, a qual aprendi a fazer teatro, essas coisas toda, só que hoje em dia falta oportunidades pros jovens da.... vamos se dizer, da Cohab, né? Moradias do bairro... porque hoje em dia muitas pessoas arrumam coisas assim,, mas lá pro lado de Santana, Centro... longe, que é pra pessoas que têm dinheiro, pra jovens que têm dinheiro e os jovens que não tem dinheiro, que são pobre, não tem dinheiro pra onde sair... pra ter um espaço pra ele, tipo um centro cultural onde você pode, onde você pode ali tá adquirindo sabedoria, fazendo teatro, pessoas ali ensinando, é.... dança, esses negócio, não tem incentivo na comunidade, então onde que tem tão a procura de que? De montar uma comunidade pra ganhar dinheiro, nas costas dos adolescentes e jovens que está freqüentando ali, então que falta muito isso, que eu acho que... eu penso assim, não sei se estou certo, fico pensando.... porque eu acho que se tivesse isso... o adolescente precisa ocupar a mente com essas coisas, acho que ele tinha menos tempo de ocupar com crime, na malandragem, no meio da rua, que é na rua que você aprende isso tudo, você aprende, você adolescente.... você tem um amigo, o amigo conheceu um tal ladrão ali que eu não conheço, às vezes até pela própria família... ah, chamar você pra conhecer um malandro ali, aí nós marcamos um negócio fazer uma fita ali, fomos lá fez a fita, deu certo, vai continuando.... agora você num centro comunitário, pro jovem, trabalhando pro jovem, o que acontece? Ali eles estão desenvolvendo coisas pra própria mente, como a própria... não sou crente, nem evangélico... eu acredito naquilo que eu vejo, né? Não sou de religião nenhuma, sou eclético, né? Então eu acredito só em Deus e pronto, mas uma palavra que está escrito na bíblia que eu gostei e acredito que é.... "mente vazia, oficina do diabo", então ocupar a mente da... juventude, então esse é o meio de muitos jovens não entrar no meio do crime, de você tirar, em vez de jogar os jovens no meio da sarjeta, no meio do... da marginalidade, você está tirando..... Então hoje em dia, graças a Deus.... é.... tomei tiro também.... na rua.... aqui eu tenho um tiro aqui na perna, tudo, por causa de briga de gang, essas coisa, briga de gang que eu falo assim... entre gótico com skinhead, essas coisa, então hoje em dia o que adquiri... só problema pra mim hoje em dia 
tenho 23 anos, não tenho grau de escolaridade bom, tenho uma passagem na justiça, então o que eu vou adquirir um bom serviço pra mim, um bom serviço que eu vou adquirir ou é de ajudante de pedreiro, ou..... qualquer outro, agora alguma firma você não arruma nunca mais.... nunca mais... então o que acontece? Vou ter que ralar muito mais pra ter uma oportunidade.... Porque graças a Deus quem tá me dando uma oportunidade é esse rapaz aí que eu trabalho no baile, certo que é pouco, mas é um dinheiro que ajuda, às vezes eu chego.... pra mim não precisar roubar nem nada, eu chego e chamo ele de tio.... é... tio P. o nome dele, tio P., eu chego e falo, "o mano, tem como você me emprestar 30 reais pra eu comprar um gás em casa?" ele vem, puxa "o dinheiro tá aqui", aí chega no dia de pagar, você vai pagar ele fala "não quero o dinheiro não, eu te dei" ele tá ali pra ajudar mesmo... então hoje em dia eu dou graças a Deus que Deus colocou ele no meu caminho, ele, a tia Elaine, que eu pego parafuso com ela pra fazer também, então são pessoas que estão ali na procura de ajudar, minha sogra também me ajuda bastante... então hoje em dia eu converso com meus irmãos, tudo, mas se eu converso no particular o dele, ele pro lado dele, eu pro meu lado, cada um com a sua liberdade, cada um separadamente...

V. Você está morando lá?

D. Eu moro no mesmo quintal, com a minha esposa, tenho meu quarto... trouxe ela pra morar comigo, a filha dela mora com a minha sogra.... que é aí, é pegado... então hoje em dia é isso, então eu procuro sempre tá andando certo, tá o horário certo na rua, o máximo é.... fico dentro de casa, não saio tanto pra rua como eu saía, se eu for ali no mercado chamo "vamos comigo", chamo minha mulher pra ir comigo, não fico mais em rodinha... hoje em dia minha vida é totalmente outra.... de 50\% minha vida mudou a $100 \%$, não saio mais, fico mais dentro de casa... quando chego em casa do serviço dou uma assistência pra minha esposa, né? Que tá sozinha, que ela não tá trabalhando mais, então eu chego, dou um beijo nela, tomo banho, almoço ou já janto, daí fico com ela, assisto uma televisão do lado dela, tou ali pra ficar junto com ela, não tem mais aquela coisa "ah, vou subir lá em cima na rua que os moleque tá ali, ah vou ficar no bar ali jogando um baralho com os moleque ali" então minha vida não tem mais essa..... de vez em quando junta eu, ela, mais minha sobrinha, mais o namorado da minha sobrinha, "há, vamos pro samba", aí chega no samba, toma uns copos de cerveja e antes de acabar já estamos indo embora, que a maioria quando acaba o baile começa a briga, então eu sempre tô correndo de confusão, correndo de lugar movimentado, aberto, esses negócio, e assim que eu vou levando a minha vida, desse jeito assim....

V. Tomara que você tenha muita sorte..... agradeço muito ....

Quando já estávamos nos despedindo, D. pergunta se eu quero que ele explique como funciona o PCC, digo que sim e começamos a gravar novamente.

D. O PCC significa Primeiro Comando da Capital, então o que acontece? Ele é uma gang, uma quadrilha, são mais de 1 milhão, são milhões de pessoas...

V. Na cadeia?

D. Isso, e fora que tem muito mais na rua ainda, e cada vez estão entrando mais, tanto na cadeia quanto na rua, então o que acontece.... que o líder disso tudo é o Marcola, o Marcola morreu, outro assume, tal pessoa morreu, outro assume, nunca vai acabar isso daí... então o que acontece? Pra você entrar tem que ter uma pessoa, 
um pouco mais.... conhecida sua, que já tem um tempo no Comando, daí o que acontece? Ele vai trazer o estatuto pra você, você não pode caguetar, você não pode estar se metendo em confusão, você não pode matar qualquer pessoa em vão, essas coisas... tem que estar sempre ali pra tentar resolver os problemas da comunidade e.... pra você vender suas drogas, você está roubando tudo, mas longe, sempre mantendo a ordem na comunidade, no bairro, então o que acontece? Daí você tem um certo concerto com essa pessoa que é chamado "companheiro leal", que é "primo leal", daí eles vem pede o estatuto pra torre, pros general que são os que tem muitos anos, né? 10 anos, 11 anos de Comando, daí eles mandam, traz o estatuto pra você, o que você pode e o que você não pode fazer, daí eles vem, ele e mais outro irmão e joga uma água na sua cabeça, está te batizando e te dá um estatuto, se você dependendo... e você tem que pagar uma caixinha todo mês é.... se eu não me engano, acho que é de 1000 reais pra quem está na rua, quem está na cadeia, no CDP, são 200 reais.

V. Quem fica com essa grana?

D. Ela vai desenvolvida tudo pra uma conta que eu não sei que fim que dá...

V. Pra comprar celular....

D. Drogas, celulares, armas é.... advogados, essas coisas toda, ônibus pra fretar pra família pra ir pro Fundão, que tem lugar, tem pessoal que é mais de 18 horas daqui pra lá, que tem famílias que não tem o dinheiro pra tá indo pra lá, então o Comando, eles dão o ônibus pro pessoal ir... então o que acontece? Se você fazer alguma coisa de errado pro Comando, então o que acontece? A única conta que você tem que pagar é com a vida, você morre, é decretado, entra mais... faz uma reunião com um monte de irmão, irmão da torre, tudo e faz aquela reunião, se vê que você está errado mesmo, você... é pedida a cabeça, então você perde seu papel, o estatuto e.... é enforcado na hora...

V. A pessoa está presente nessa reunião?

D. Isso, a pessoa que é do Comando está presente, que nem eu já freqüentei reunião tudo, mas eu era Primo Leal, né? E... não era do Comando...

V. Você não era do Comando e pode freqüientar?

D. Pode que era consi... que eu andava com ladrões do PCC, né? Da quadrilha do PCC, que é considerado Primo Leal... então o que acontece? Daí você tem que pagar todo mês uma taxinha, se você não pagar essa taxinha, você é excluído...

V. Uma taxinha alta, né? 1000 reais....

D. Pra quem rouba, né? É pouco, que nem antigamente você pegava uma carga, nós pegava uma carga, vamos colocar... uma carga de..... celular, nós conseguia mais de 20 mil, mais de 50 mil, que cargas tem os compradores certos, né? Hoje em dia é assim, antes da carga sair da loja você já sabe que carga que está saindo, que caminhão que tá e quantas escolta tem e naonde é o ponto certo pra você está catando, então o que acontece? Você tem que pagar essa taxinha, se você não pagar você é excluído 15 dias de gancho, é... 15 dias de excluimento, se você não pagar, daí você é excluído de vez, dependendo do seu padrinho, se for um padrinho forte, com muito tempo de Comando, de PCC você mantém vivo, você fica vivo, senão você morre também e na única facção que é permitido entrar na cadeia do Comando mesmo é a..... como que é o nome? O Comando Vermelho CVE... é alguma coisa assim, a única....

V. O Comando Vermelho é do Rio, né?

D. É do Rio, é do Rio, mas tem muitos caras que é carioca que corre lá com o Comando Vermelho, que hoje já estão tudo em São Paulo, às vez que vem de Bonde 
pra São Paulo também e assim.... daí pode entrar na cadeia do Comando, é respeitado, tudo...

V. Tem essa história de desistir de ser do Comando?

D. Não pode...

V. Se você era do Comando, agora não está mais nessa vida, não quer mais....

D. Não pode sair mais, só por excluimento....

V. E que vantagem você leva em se associar ao Comando?

D. É.... pra falar a verdade... no meu modo... sempre pensei não leva a nada.... que você leva que você tem mais uma liberdade na cadeia, que nem, o que acontece? Pra população é chuveiro mesmo gelado, agora na faxina, no esporte, é chuveiro quente, chuveiro ali é elétrico mesmo, o resto da cadeia é chuveiro gelado, é.... faxina... o esporte onde fica os irmão, o pessoal que é mais associado com os irmão, que pode ficar solto... o esporte pode ficar solto até às 5, daí o esporte é trancado, depois só fica os faxina solto até as 9 horas da noite, daí limpa, paga a alimentação, que os funcionários, eles não dão alimentação, não dão nada, os próprios preso, que é o setor da bóia, vai lá, pega a alimentação lá dentro e traz em cada rua, daí deixa na... na porta da cela, da gaiola, daí o funcionário vem, abre, daí o faxina vai lá e separa a alimentação, pega a alimentação, daí vem e paga nos barracos, que tem barraco, que nem às vez nós ficamos lá em $58 . . .58$ pessoas presa, num espaço com daqui .... ali.... que tem que dormir no chão, é.... só os colchão tudo furado e você dormindo um pra cima e outro pra baixo... eles chama de valete...

$\mathrm{V}$. E sem encostar em ninguém....

D. É pode encostar, né? Fazer o que? Mas como é em valete, fica bunda com bunda e tipo assim... eu tô aqui de cara com o pé de um, de frente com uma, mas com pé, na minha cara... e assim..... se você..... o PCC é isso daí, então lá eles roubam, fazem a atividade deles, como todo ladrão, mas está ali pra..... procurar direitos. Hoje em dia através do PCC que hoje tem muitas coisas dentro da cadeia que não tinha antigamente, o direito de ter visita íntima, de ter uma alimentação mais adequada, é.... essas coisas... você não ser mais agredido pelo choque, é.... coisa que antigamente era feito é.... através do jeito deles que é o jeito errado, né? Mas é o único jeito pra gente chamar a atenção da reportagem pra situação da população... que nem esses ataques, esses negócio, foi o modo de chamar a atenção, de parar São Paulo pra ver uma coisa, colocaram... mandaram pessoas colocar placas na rua, tudo, pra explicar pra população que não era pra população, nós estava matando polícia, polícia, carcereiro que estavam realmente prejudicando nós, que nem... carcereiro que bate em nós lá dentro, machuca nós lá dentro e nós não pode fazer nada com eles lá dentro, então tem pessoas do Comando que já faz isso aqui fora, primos leal, pessoas assim... é um modo de chamar a atenção.. pra ver o processo, tá entrando com algum recurso pra lá pra dentro... é direito de entrar visita que não seja familiar, de..... entrar uma alimentação mais adequada pra nós, é... pra gente adquirir, que nem na Colônia, na Colônia, você já chega na Colônia, né? Lá dentro pra você falar com o diretor da Colônia você tem que fazer a barba, não tem que tá com barba nenhuma, então chega lá eles já te dão prestobarba pra você fazer a barba, pra você cortar o cabelo, né? Baixinho, pra você falar com o diretor tem que manter a disciplina, aquela disciplina, cabelo baixo e sem barba, pelo menos pra ir na diretoria, lá dentro do prédio você anda como que você quiser... então o que acontece... lá eles já dão sabonete, única coisa também, eles já dão sabonete, pra você... único modo de higiene, agora... CDP não dá sabonete, não dá... que nem antigamente no Carandiru, não dá fronha, não dá cobertor, não dá colchão, não dá nada, você tem que se virar 
com o que tem lá... Se você conseguir alguém que traga pra você aceitam, mas se você não tiver uma família, não tiver visita você não tem nada, só se algum.. alguém tiver um coração bom lá dentro e ceder pra você... sai e deixa pra outros... que nem, a única coisa que você sai de lá de dentro é com um short, uma camiseta e um chinelo, todo estourado, com a camiseta rasgada, short rasgado, que é o que você sai lá dentro, as roupas boas você deixa pros outros companheiros, daí você deixa no barraco... os meninos se dividem lá, daí depois manda pro RO e assim vai indo.... é isso aí.... 
Transcrição entrevista Lucas

22 anos

Entrevista concedida dia 01/11/2006 nas dependências da Associação Novolhar

V. Queria que você contasse pra mim, que a gente começasse a conversar com você contando um pouco sobre a sua vida, no geral, onde você nasceu, contar um pouco da sua trajetória.

L. Viche, é longo....

V. Não tem problema, você está com tempo?

L. Tenho....

V. Então vam' bora.

L. Então, eu nasci no Bairro do Limão, na Casa Verde, morei lá na... ali na favela do Agreste, ali com a minha mãe, morei com ela até os 4 anos de idade... Então, morei no Bairro do Limão até os 4 anos de idade com a minha mãe, por dificuldades, que a minha mãe bebia muito e eu que tinha que carregar os meus irmãos nas costas e o pessoal, os vizinhos resolveu chamar o SOS Criança e nisso que o SOS Criança veio e tirou nós, eu e meu irmão da nossa mãe....

V. Você tinha quantos anos nessa época?

L. Eu tinha 4 anos, meu irmão tinha 3, e aí tinha eu, meu irmão, minha irmã que tinha 2 e um que tinha 8 meses, acho....

V. E os vizinhos chamaram o SOS por que?

L. Chamaram o SOS Criança porque minha mãe batia demais na gente e ela bebia demais, aí a gente foi parar no SOS Criança, aí eu e meu irmão ficou no SOS Criança, desde os 4 anos até os 9 anos de idade. Depois, nesses 9 anos de idade a gente foi morar com, foi morar com um Padre, o Padre Jaime lá da Pompéia, aí a gente morou um tempo com ele, morou acho que 3 anos com ele...

V. Era uma instituição?

L. Não, lá ele pegava meninos de rua...

$\mathrm{V}$. Ele que cuidava?

L. Ele que cuidava... aí o pessoal acabou conhecendo ele e encaminharam a gente pra lá, a gente morou com ele até os 11 anos de idade. Nesses 11 anos de idade, a minha mãe chegou a falecer, aí eu fui morar com a minha família, tudo, aí eles me tiraram de lá e eu fui morar com a minha família lá em N. P. Morei em N. P. até os 14 anos de idade, aí eu peguei e voltei, nessa que eu voltei, fui morar em São Mateus com a minha vó, aí eu morando com a minha vó em São Mateus, eu tipo, tipo queria trabalhar, não conseguia serviço é.... as pessoas não aceitava, falava que era menor de idade, então, a gente .... conforme naonde que eu morava, que lá é perigoso, era perigoso na época, antigamente era mais perigoso do que é hoje, hoje é mais tranqüilo, mas antigamente era fogo. Então a gente começava a tipo, a ter uma amizade diferenciada, um chegava "e aí, vamos fazer isso, vamos fazer aquilo" aí a gente não, não sei que, mas tudo começa, sabe, tipo, você quer comer uma bolacha você não tem dinheiro, tudo começa ali no mercado, no mercado do lado da sua casa.... a gente vai pegava bolacha, pegava Danone e assim começava 155, 155 escondido.... aí nisso eu comecei a ... comecei a andar com esse pessoal, tudo, mas nunca chegava a me envolver com eles... aí chegou o tempo que eu queria tênis, queria roupa, queria aquilo, sabe, ninguém me dava.... então eu comecei a .... roubar, comecei a roubar, aí eu comprei minha arma...

V. Sozinho você ia? 
L. Sozinho, nunca gostei de ir com alguém porque era, eu achava que era trairagem, porque se você pegasse uma coisa alta, aí um podia ser traíra com o outro, que nem acontece várias ocasiões que um chega a matar o próprio amigo por causa do dinheiro, então eu comecei a roubar sozinho, comecei a roubar e tudo e foi nisso que eu acabei sendo preso com.... 17 anos, de 16 pra 17 anos...

V. Até lá você roubou várias vezes antes de ser preso, ou não?

L. Várias.... várias...

V. O que você fazia? Só furto?

L. É... era mais furto, mais furto..., mas tipo algumas vezes já troquei com polícia... porque que ou, ou eu atirava ou eles me matavam....

V. Ou você ou eles...

L. É... aí eu peguei.... e fui preso, né? Acabei sendo preso, aí... eu fui pra Parelheiros, fiquei lá em Parelheiros um tempo...

V. É uma unidade da Febem, né?

L. É uma unidade da Febem, onde que era mais perigosa do que Franco da Rocha, né?

V. Era a de infratores mais graves...

L. É, isso...

V. E mais velhos, você já tinha $17 \ldots$

L. E mais velhos... e assim... tipo eu não via, eu não via inspiração pra mim lá dentro, tipo, eles falam que Febem resgata, é pra resgatar os adolescentes, mas ali tem... fica totalmente no mundo do crime, ali não tem resgate, ali é pra você se afundar cada vez mais...

V. Não tem atividade, não tem escola, não tem nada lá?

L. Não, tê tem, mas é... o trato... o .... como é que se diz, o trato da pessoa, o trato do ser humano, entendeu? Eles não tratavam a gente bem, tratavam a gente mal e a gente ficava mais trancado do que saía pra jogar bola, saía pra estudar, então a gente não via vantagem em nada, então o que que a gente fazia, a gente ia fazer rebelião toda hora pra fugir, entendeu? Aí eu peguei... depois do tempo que eu fiquei lá eu fui parar na... fui pra Semiliberdade...

V. Você cumpriu Parelheiros direitinho? Saiu em alguma rebelião?

L. É, eu cumpri...eu cumpri lá sossegado aí eu peguei Liberdade Assistida, aí eu fui... ali na estação Armênia, ali...

V. Semiliberdade lá, né?

L. Semiliberdade, isso, aí tipo... na semiliberdade a gente podia todo final de semana ir pra casa, né? Ficar com os familiares, e nisso meu, meu avô, ele não me aceitou de volta, ele não me aceitou de volta e isso foi inspiração nenhuma, falei: ah ele não me quer de volta, não tenho mais ninguém, então eu vou... me afundar, entendeu? Eu tô nessa vida, eu vou prosseguir do jeito que eu estou aí... tipo eu tinha um amigo lá, um amigo e a mãe dele gostavam de mim muito, então ele era um amigo tipo irmão, entendeu? Lá no bairro... e aí a mãe dele ligou lá pra semiliberdade e falou "ó, pode deixar ele vim passar o final de semana na minha casa, né?" Aí tá, eu ia todo final de semana passar na casa dela lá... Aí nisso que eu fui passando o final de semana lá na casa dela, eu fui, tipo, meu vô foi vendo que eu estava mudado, entendeu? Mas ele não sabia que eu estava a fim de aprontar mesmo, não queria nem saber se eu ia pra Febem, pra onde que eu ia...E nisso eu já tava com os meus 19 anos, eu acho, é 19 anos, aí eu peguei e..... peguei... peguei... é que lá na semiliberdade, as pessoas podiam fazer vários cursos, entendeu? Podia fazer curso de computação... aparecia uns cursos lá que os outros pessoal, os outros meninos iam fazendo, né? E eu não me 
interessava por nada, queria ficar o dia todo lá soltando pipa, pegando pipa e jogando bola... e só pensando em maldade e aí nisso apareceu uma oportunidade de eu fazer um curso na Novolhar, de televisão, é.. Rádio e Televisão. Aí, não sei que que me deu que eu me interessei, aí tipo era... 3 vagas pra 20 adolescentes lá, aí eu, como eu era o mais velho da casa eu falei: ó, uma vaga é minha, o resto vocês se vira. Aí tá, como eu era o mais velho, foi isso mesmo. Aí eu fui fazer o curso a primeira vez, aí eu fiquei meio assim, né? Aí eu falei, ah, não sei que... Aí o coordenador lá falou "e aí, você vai vir outra vez?" Peguei e falei: vou ver. Aí eu estou lá na semiliberdade, não tinha nada pra fazer eu falei vou lá, aí eu fui a segunda vez, nessa segunda vez eu comecei a ir, a ir e tipo a gente lá tinha aula, aula, antes de pegar na câmera, pegar na VHS, que a gente aprende, começou a aprender primeiro pela VHS, a gente tinha aula teórica, como era a câmera, o que fazer com a câmera, então eu...eu ia pra lá, mas eu não ligava pra isso... eu ia pra lá dormia, ficava conversando eu não me interessava, mas na hora que a gente ia sair pra rua pra fazer alguma matéria, eu era o primeiro a pegar na câmera, sem saber é... sem saber eu já queria fazer as coisas e o pessoal que já tinha um pouco mais de noção, já sabia pegar a câmera e fazer.. eu não, já fui direto na câmera e fuçando, fuçando eu já comecei a fazer algumas coisas, foi aí que... o Paulo Santiago ele pegou e começou a me chamar pra fazer uns freela de assistente de câmera, né? Aí tá, aí eu comecei a fazer assistente de câmera e teve, teve, teve um menino que, que estava comigo lá, que ele já estava fazendo câmera e a gente ia fazer o trabalho pra Febem, tinha que passar em todas as Febems e gravar, não sei que que os meninos iam receber de computação do Chalita, aí ele queria ver essa matéria, aí esse Câmera aí que estava comigo lá, ele ganhou a liberdade dele, ele morava em Bauru, ele teve que ir embora, aí só estava eu e o Paulo, o Paulo pegou e falou "e agora, o que a gente vai fazer?" eu falei, não, eu sei gravar... sei gravar e foi nessa que eu passei em todas as Febems, gravei, e o Chalita assistiu tudo, todo mundo gostou, aí o Paulo começou a me chamar pra fazer outros trabalhos, aí comecei a ser câmera do Novolhar, aí nisso, teve uns outros adolescentes que veio fazer curso... tudo, começaram a fazer cursos, eu ajudava eles, tudo e sempre fazendo freela pra Novolhar, fui fazendo aí, tipo eu falei, não, vou correr atrás por mim mesmo, aí eu comecei a correr atrás... fui trabalhar pro Padre Antonelo, aqui embaixo, perto do Parque D. Pedro, ali, comecei a fazer o programa do Padre Antonelo...

V. Gravando também?

L. Gravando também, aí tipo eu... eu peguei fui... fui fazer um trabalho pra TV Futura, pro Gilberto Dimenstein, aí lá.... na onde que eu fui fazer esse trabalho, eu não fazia nem câmera, nem assistente de câmera, eu fazia assistente de produção e tipo... eu achava que era bom, né? Porque televisão você tem que aprender tudo, desde a câmera até produção pra saber tudo que acontece, né? Ter uma noção de tudo. Aí eu peguei, fiquei trabalhando com ele durante 3 meses, com o Raí e o Gilberto Dimenstein e os outros pessoal, aí eu peguei e fiquei desempregado, né? Porque eles fizeram contrato comigo de 3 meses, aí eu voltei pro Novolhar, comecei a fazer os freela na Novolhar, aí teve um... a Novolhar teve um... teve um projeto que..., não conseguiu o projeto não, a Novolhar tem... tem um programa com a TV PUC e reuniu vários jovens pra, pra fazer esse programa e eu estava invisível também, tava eu, o Rafael e mais um fazendo câmera pra esse programa, aí tipo... passou um mês, 2 meses, aí eu peguei, como que eu tinha meus contatos, o... volta, posso voltar?

V. Pode, claro... 
L. É... quando eu estava na semiliberdade que... que eu comecei a fazer o projeto da... o...o curso da Novolhar, teve um pessoal da TV C. que foi lá, foi lá gravar, gravar o projeto da Novolhar, tudo, aí eles se interessaram, se interessaram na minha vida e foram conversar lá com a minha família, né? E nisso meu vô falou, falou na... pra eles mesmos que não me aceitava de volta e isso e aquilo... Como é que eu tô? Eu tô tipo, indo pra frente.... Aí que o meu vô falou que não me aceitava isso e aquilo e eu conheci os pessoal da... da C., tudo e eu fiquei, ficou como um contato, mas nunca esperava nada, aí eles me chamaram um dia pra eu ir lá visitar, eu fui lá, visitei, conheci a C., tudo e nisso, só ficou por isso e mais nada, aí tipo eu conheci a Neide e a Ana Lu lá da TV C., de quando elas trabalhavam lá, que hoje elas estão na G., aí eu peguei e tipo, comecei a fazer os trabalhos pra Novolhar, tudo e meu vô e meu vô viu que eu estava fazendo coisas diferente, que não estava com aquele mesmo pensamento, entendeu? Aí ele falou "ó, vem passar o final de semana aqui em casa". V. Ainda na semiliberdade?

L. Ainda na semiliberdade, é ele falou "vem passar o final de semana aqui em casa", aí eu fui, comecei a passar o final de semana lá, fazendo curso na Novolhar, tudo, aí ele... eu tinha que sair da semiliberdade, que eu peguei, tipo um alvará, uma saída, é... Liberdade Assistida, aí eu peguei Liberdade Assistida, aí... meu vô viu que eu estava mudado, que eu não queria mais essa vida pra mim, tudo... eu conversava com ele e fazendo esses trabalhos pra Novolhar, foi na onde que... que eu... é.... acabei de falar que eu fui fazer.... é fui fazer trabalho pro Padre Antonelo, fui fazer trabalho pra TV Futura, aí eu voltei, tinha voltado pra Novolhar, pros cursos da Novolhar aí eu peguei fui fazer o programa lá da TV PUC, e passou dois meses... eu peguei e falei, não, eu preciso ver alguma coisa mais... sabe, eu quero televisão mesmo, eu quero ver qual que é, e tipo, eu tinha o telefone da Ana Lu e da Neide, aí eu do nada, lá em casa, fuçando nas minhas coisas achei o telefone delas, vou ligar... nisso que eu liguei, tinha uma vaga lá de boy de jornalismo, aí tipo, mas sabe, eu não estava tão interessado assim, é... eu queria câmera mesmo, aí eu conversei com o Paulo, conversei com o pessoal que estava aqui, e nisso o Paulo não queria que eu fosse, o Paulo queria que eu continuasse na Novolhar, mas aí eu pensei assim, né? É registrado, uma coisa pra mim pro futuro, né? Aí eu peguei, fiz um, tinha gente que não queria que eu saísse da Novolhar, peguei e falei, não, eu vou só pra mim ver como que é, aí a mulher, a C., a mulher da TV C. que trabalha lá no... RH, pegou e falou "faz um teste uma semana, fica aqui uma semana, se você gostar, você continua, a gente te registra, se você não gostar, tudo bem", aí tá, eu fiquei uma semana lá e gostei... eu comecei a fazer lá, eu fui pra lá, comecei a trabalhar de boy de jornalismo, nisso eu fui conhecendo muita gente, sabe? A (....?) que hoje está na Record, fui conhecendo bastante gente, entendeu? Aí, tipo eu já estava um ano lá, todo mundo gostava do meu trabalho, tudo, eu comecei a fazer... como que eu gostava de câmera eu comecei a fazer, comecei a fazer cabo-man lá, aí eu ligava a câmera da redação, tudo pro jornal, aí eu chegava, que eu entrava das 7 às 3 da tarde, então eu chegava, fazia primeiro o trabalho que eu tinha que fazer da minha função e quando eu tinha um horário vago, eu ficava lá, eu ligava a câmera da redação, ligava a televisão da redação, tudo, e todo mundo via meu interesse, via que eu estava bem interessado e todo mundo gostava de mim, aí teve, que que aconteceu lá, que tipo...é.... teve umas mudanças lá que mudou o chefe... não sei se é bom eu falar....posso falar?

V. Pode.. 
L. Aí teve umas mudanças lá que mudou os chefes e mandou um pessoal embora, tinha mandado um pessoal embora e veio um pessoal novo, aí todo mundo lá sabia que eu morava em São Mateus, sabia que eu morava em São Mateus, sabia meu telefone, sabia meu e-mail, tudo, que lá a gente comunica todo mundo, né? Porque se alguém quiser mandar alguma coisa, aí, pegaram, não sei quem foi lá, pegaram e ligaram assim, pro puteiro, sabe? Esse negócio de... disk sexo? Então, ligaram pra esse negócio e deram o meu e-mail, falaram meu nome, que tipo, todo mundo lá me chamava de L., de G., entendeu? Aí pegava e falava, ah o L. G., aí teve uma menina que perguntou lá "qual que é seu nome?" eu L. G., "Por que S. G., seu e-mail?" Entendeu? Aí eu, ah, porque eu gosto, isso e aquilo, aí o... o rapaz desse lugar pegou e ligou lá pra minha sala, né? Pegou e ligou pra minha sala e falou comigo, falou "ó, você ligou pra tal, que está gravado, tudo" eu peguei e falei, não liguei, né? Não foi eu que liguei, ele falou "não, o pessoal do RH está sabendo, isso e aquilo" falou "e eles vão conversar com você" eu peguei e falei ó, eu não sei se isso é trote ou o que que é, entendeu? Mas eu vou conversar com a minha chefe agora, senão pode me prejudicar aqui dentro, né? Aí tá, aí o cara pegou e falou "não, não precisa conversar com ela..." tipo, querendo, disfarçar... eu falei, isso aí deve ser trote, aí ele pegou e falou, vou colocar a voz da pessoa aqui, que ligou. Aí estava eu e o outro rapaz que trabalhava comigo dentro da nossa sala lá, aí ele pegou e colocou, né? O rapaz falando com a menina, aí eu peguei e falei, passei pro meu colega que estava lá do meu lado, que trabalhava comigo e falei, ó o cara está falando aqui que fui eu que liguei, escuta a voz aqui... é, não era, não tinha nada a ver com a minha, não tinha nada a ver, aí ele pegou e falou "desliga isso daí que isso aí é trote", aí eu peguei e falei, não, vou escutar até o final, escutei até o final e aí o rapaz de lá pegou e falou “você escutou?" escutei, aí ele pegou e falou “ó, não é você não, mas alguém quis te prejudicar ou alguém quis brincar, ou fazer não sei que, mas quis te prejudicar" aí eu peguei e falei: não, pode ficar tranqüilo eu vou falar com a minha chefe, ele falou "não, não precisa, não sei que, vamos deixar isso daí pra lá" eu peguei e falei: se você falou com o pessoal do RH, eles vão cair na minha chefe e se eu ficar quieto vai sobrar pra mim, entendeu? Aí tá, aí.... eu cheguei na minha chefe, tipo minha chefe, sabe? Ela... ela dava a alma pra gente, ela gostava muito da gente, mas teve uma mudança lá, que como veio esses outros chefes, ela subiu de cargo e ficou a secretária dela como nossa chefe, entendeu? E essa secretária dela era tipo, sabe, era uma pessoa que, meu se está tudo bem, está tudo bem e se você falou um "A", ela está contra você, entendeu? ela não quer nem saber se você está certo ou se você está errado, aí eu conversei com ela tudo e ela "mas por que você deu, é... por que todo mundo sabe seu e-mail?" Eu peguei e falei, porque é... mesmo a gente saindo do computador, lá tipo a gente tem o MSN, mesmo a gente saindo, fica gravado lá e tipo, se a outra pessoa quer entrar no MSN ela tem que colocar o... é, tirar o meu e colocar o dela, quando ela sai fica gravado também, aí ela "mas como todo mundo sabe seu MSN?" eu falei: porque a gente fica no computador, porque quando a gente está nas horas vagas, "orra", todo mundo tem o MSN aí, todo mundo conversa, quer dizer... "ah, não sei o que, que não pode ficar no MSN, que aqui é local de trabalho" eu sei que aqui é local de trabalho, eu faço isso nos meus horários livres, como tá tendo as mudanças aí do pessoal eu não sei quem é quem, entendeu? Aí tá... aí fui lá, conversei com a T. do RH, tudo... ela falou "não G., pode ficar tranqüilo que isso daí deve ser trote" aí eu peguei e falei, não, tudo bem, eu só estou avisando pra..., entendeu? Não me sujar no meu trabalho... aí passou 2 dias eu tô no meu... tô lá 
trabalhando normal ela pega e me chama, me chama lá, né? Me chama lá e fala que vai me mandar embora...

V. A sua chefe chamou?

L. Não, a T. do RH, falou "ó você está sendo despedido por causa disso..." eu peguei e falei: ó, vocês podem me mandar embora por justa causa se for eu, mas eu quero que vocês me provem que foi eu, né? E nisso ela ficou enrolando, enrolando, enrolando, enrolando e chamou e chamou, não sei quem lá, um advogado de lá da C., não sei quem foi, chamou essa minha outra chefe que era secretária lá e a gente conversando, conversando, ela pegou e perguntou pra essa secretária e falou se ela confiava no nosso trabalho, né? Ela falou "ó, você confia nos boy, não sei que" ela pegou e falou "não, não confio em nenhum boy"... tipo e.. na onde que ficou minha cara?, entendeu? Pô meu, ela trabalha com a gente... ela dava dinheiro, ela dava cheque pra gente buscar dinheiro no banco, valor que.... a gente nunca tinha visto na vida, entendeu? Tipo $25 \mathrm{mil}, 30 \mathrm{mil}$, a gente ia no banco, pegava, levava lá, fazia tudo certinho, fazia todo o trabalho certinho, todo mundo gostava da gente, não tinha o que falar, entendeu? não tinha o que falar...aí tipo, ela pegou e falando, falando... eu peguei e falei, ó se vocês me provar que foi embora, que.... que eu fiz isso, vocês podem mandar por justa causa, eu não quero receber nada, entendeu? Aí ela pegou e estava enrolando lá, ficaram enrolando, ficaram enrolando e pegou e falou "pode trabalhar normal", peguei e falei: tranqüilo, mas se vocês conseguir provar vocês podem me chamar e eu vou, né? Aí ela pegou e falou "ó, eu tenho o telefone, eu tenho tudo gravado aqui na... na tudo gravado" eu peguei e falei: então coloca agora entre nós três aqui eu quero ver se prova que foi eu e nisso ficaram enrolando e não provaram nada, aí me falaram pra eu ir trabalhar normal, tipo já... já estava quase o horário de eu ir embora, eles falaram "não, pode trabalhar normal”, tá bom. Aí eu voltei no outro dia, quando é.... a gente, tipo o jornal lá começava meio dia, né? Quando é 10 pra meio dia só tinha eu, né? Pra subir as laudas, subir as fitas, tudo, aí quando é 10 pra meio dia veio o outro menino que trampava de tarde, eu falei: o que você está fazendo aqui? "ah...a outra mandou eu vir de manhã, não sei que" aí essa... a secretária que estava de chefe lá, ela pegou e me falou "ó, a T. quer falar com você lá no RH", aí eu fui lá, peguei e falei: pode falar que está na hora do jornal e eu tenho que voltar correndo, senão atrasa tudo lá, ela pegou e falou "não, você não precisa voltar, você está sendo despedido" Aí eu peguei e falei: não, mas cadê? Vocês provaram? aí ela falou tipo "não, isso aí é o chefe.... chefe, não sei que que está mandando e a gente não pode fazer nada" entendeu? Aí eu peguei e falei: pô mano, mas assim vocês acabam comigo, entendeu? Como que pode isso daí acontecer? A pessoa faz tudo certinho, ninguém aceita, agora quando acontece alguma coisa... e tipo essa secretária aí, ela sabia que eu tinha passado pela Febem, entendeu? Que minha chefe confiava tanto nela que foi e falou e tipo, eu tinha falado pra minha chefe: ó, não fala pra ninguém que não é bom, não é todo mundo que tem esse pensamentos que a pessoa mudou, que a pessoa está afim de fazer o trabalho, tudo, não é todo mundo que vê desse jeito, é não sei que e acabou contando pra ela, acho que em um bate papo delas... todo mundo falava bem da gente lá, acabou contando, entendeu? E eu acho que ela julgou nisso, porque eu tinha passado pela Febem.. é... pra mim tinha a ver com isso, entendeu? E essa T. do RH também sabia porque ela que tinha me colocado lá, né? Aí tudo bem, né? Aí...eles pegaram e me mandaram embora, eu peguei e falei: ó, não vou assinar, eles queriam que eu assinasse a demissão, né? Eu peguei e falei: eu não vou... não vou assinar nada enquanto eu não falar com o pessoal do sindicato. Eu fui lá, conversei com o cara do sindicato, o cara 
do sindicato foi lá e conversou lá, falou e aí, não sei que, aí o A., o A. que é chefe lá agora, tipo o A., na hora que ele chegou que ele viu meu trabalho, porque tinha que ser rápido, entendeu? $\mathrm{O}$ apresentador está aqui, o apresentador tá desse lado, saiu sabe? Tinha que ser rápido, entendeu? Ele pegou e falou, nossa, gostei do seu trabalho, sabe? Então... ele gostava do meu trabalho, que ele estava chegando agora e já tinha visto meu trabalho e nossa! Sabe? Era G. pra lá, G. pra cá... e tinha um outro que estava com ele, eu esqueci o nome dele agora e tipo isso daí foi parar no ouvido dele, entendeu? E foi parar nos ouvidos dele, entendeu? Eu não sei se foi parar ou se... se, tipo o A., ele era o chefe, mas tinha o outro, o C., você já ouviu falar do C.? Ele... ele trabalhava na Gazeta, aí eles foram pra C., aí o C., o C. também gostava do meu trabalho, entendeu? Ele brincava comigo direto, não sei que...Aí a X, essa que é secretária, ela foi lá e meteu o pau em mim, entendeu? Meteu o pau, falou isso, falou aquilo e tipo... cheguei no C. e o pessoal do sindicato foi falar com o C. e o C. falou "ó, não tem jeito, não sei que, que o que aconteceu foi grave" eu peguei e falei: mas C., peguei ele, pra conversar só eu e ele, falei: meu, você conhece o meu trabalho, você vê o jeito que eu sou e tudo, você está chegando agora e está vendo, entendeu? Pergunta pros outros pessoal aí que trabalhava comigo já mais de um ano, sabe do jeito que eu sou, eu não preciso fazer isso e tipo eu fui bem limpo com ele, entendeu? Eu peguei e falei: meu se eu fosse fazer isso, eu tenho minha mulher em casa, se eu fosse fazer isso era mais fácil eu pegar meu pagamento aqui, pegar 10, 20 conto e ir pro puteiro, do que ficar ligando e passar meu e-mail? Isso aí é coisa de... é coisa de quem não tem o que fazer, né? Aí ele ficou meio assim, sabe? Ele acreditou em mim, sabe? Mas... Aí veio aquele porém, o que a X. tinha falado? Entendeu? Aí ele pegou e falou "não dá, não sei que...não dá mais...." e eu tive que sair mesmo, eu tipo.... as outras pessoas que gostavam de mim lá começaram a chorar e tipo, não acreditava e tipo, se elas se envolvesse, sobrava até pra elas, entendeu? Aí eu peguei e falei: não mano, pode ficar todo mundo tranqüilo, aí todo mundo... "mete no pau, não sei que, mete no pau...." aí eu vim, conversei com o Paulo, tudo, o Paulo pegou e falou "ó sabe o que é melhor? Esquece isso daí, procura outro, tenta procurar outro emprego, entendeu? E se as pessoas gostavam de você, entra em contato com eles..." aí eu peguei e falei: não, tranqüilo, aí eu fui, recebi meus benefícios, tudo.... o pessoal do sindicato também falou pra colocar no pau, mas aí o que que acontece? Se eu colocasse no pau, e depois, se eu quisesse entrar em outra emissora? Como que ali é uma rede de televisão, eles conhecem tudo, entendeu? Iam falar "ah não, ele colocou a gente no pau, então não vamos aceitar ele, né?" Peguei e falei: não, tranqüilo, peguei meus benefícios, como eu morava de aluguel... morava eu e a família da minha esposa, que eu tinha saído já da casa da minha vó e tinha ido morar com ela, entendeu? Aí eu peguei e falei: não, quero ter a minha vida, né? Peguei esse dinheiro aí que eu tava e eu tinha uma moto e eu tenho um Chevete também, né? O carro, aí eu peguei e falei: não, vou vender minha moto, tipo eu tava devendo nas Casas Bahia, eu vou vender minha moto, quito as Casas Bahia e aí eu vejo o que dá pra mim tirar, né? Aí eu peguei esse dinheirinho e comprei um terreno lá pra mim construir minha casa, eu e minha esposa, entendeu? Aí eu falei, a gente tem que ter o nosso lugar, a gente pegou, construiu nossa casa lá, tudo e tirou os móveis nas Casas Bahia e aí tipo... fui recebendo meu seguro desemprego, fui pagando, fui pagando aquilo, isso e aquilo e aí tipo... comecei a correr atrás de emprego, né? Aí eu peguei.. tinha um contato, tinha contato com o pessoal da Gazeta, que o pessoal que tinha saído da C. foi pra Gazeta, foi pra Globo e... eles pegou, eu fui lá na Gazeta, me receberam muito bem, conversaram comigo, tudo... eles falou ó, a gente vai tentar te 
encaixar aqui de qualquer jeito e tipo... eu fui lá, entreguei o meu currículo, eles pegaram o meu currículo, ficaram lá na mesa deles, eles entregaram 2 lá no RH, tudo... a gente só está esperando ter vaga e a gente já te chama. Aí eu fui na Record, agora que o C.S. está lá, eu estou procurando entrar em contato com ele, pois como que ele está ... ele é conhecido lá, ele pode me ajudar, que ele também gostava do meu trabalho, entendeu? Aí eu estou procurando contato com ele... é... porque hoje em dia, se você não tiver um contato é bem difícil, né? Aí como que a Novolhar tá, sabe? Não está tendo freela, não está tendo essas coisas, então eu tô procurando vários empregos, entendeu? Porque eu não quero, eu não procuro ter aquele pensamento, pô tô precisando eu vou roubar, roubar sabe? Por que eu sei que hoje eu tenho 22 anos, já... eu sei que, se eu for preso, ninguém, ninguém vai... depois... é... tipo, eu não vou conseguir recuperar minha vida, entendeu? Mesmo... eu tendo minha casa, eu tendo minhas coisas eu não vou conseguir voltar pra... que isso daí vai me prejudicar, então meu pensamento é o quê? É eu conseguir fazer alguma coisa, entendeu? É eu chegar e... bom.. vamos... o que que tem pra mim fazer, sabe? E qual o trabalho que tem? Se não tiver nada na parte que eu gosto de câmera... alguma coisa, qualquer trabalho, entendeu? Eu saio procurando por aí, entrego currículo todos os dias... acordo cedo, vou lá no sindicato, no.... sindicato em Santo André que eu moro lá perto, eu moro em São Mateus, mas fica do lado, aí eu vou pra vários lugares entregar currículo, tipo eu não abaixo minha cabeça, entendeu? Quando eu tô com dificuldade em casa, tá faltando isso, tá faltando aquilo, então eu chego no Paulo e falo: pô Paulo tá faltando isso, tá difícil.... o Paulo sempre me dá uma força, entendeu? Tipo... ele não abaixa o meu astral, ele "você vai conseguir...isso e aquilo, continua tentando" então eu sempre tô procurando, sempre tô, assim, procurando algum trabalho pra mim não abaixar a cabeça e não pensar negativo, né?

V. E você tem, como que é sua vida hoje, você sai com amigos, você tem filhos, como que é?

L. Não, por enquanto não tenho filhos, acho que... assim, eu penso por mim mesmo sabe? Pra ter filho tem que ter uma vida boa, assim, não uma vida rica, sabe? Mas uma vida que dá pra mim levar sossegado, um emprego que eu sei que está garantido, então vai estar tudo bem, porque não adianta eu fazer que nem meu pai fez, ou que nem minha mãe fez, me colocar no mundo e me jogar pro SOS Criança, entendeu? Eu praticamente, eu fui criado sem família, eu fui criado, eu e meu irmão, sozinho e tipo, meu irmão ele foi um guerreiro, porque tipo... depois que a gente saiu disso tudo, ele... que estava no SOS Criança que ele era menor, né? A gente... depois disso tudo, ele tipo, foi servir o exército, hoje ele... depois ele saiu do exército, hoje ele trabalha com restaurante, entendeu?

V. Ele nunca passou pela Febem?

L. Nunca passou pela Febem, ele, sabe? Teve mais cabeça do que eu... mesmo eu sendo mais velho, ele teve mais cabeça do que eu.... ele não se deixou levar. Mesmo assim a gente teve uma coisa da nossa mãe, que nossa mãe bebia muito e morreu de overdose, aí a gente teve uma coisa que a gente carregou pra gente mesmo que a gente nem bebe nem fuma, entendeu? A gente não vê vantagem nisso, a gente não gosta mesmo desde... desde pequeno mesmo ... e a gente, a gente se comunica, a gente conversa, ele tenta arranjar alguma coisa lá pra mim no serviço dele, então a gente está sempre com contato e eu falei pra ele, o dia que você precisar da minha casa, minha casa vai estar sempre aberta... e tem a minha irmã que mora com a madrinha dela, meu outro irmão, ele foi adotado, quando nós era pequeno ele foi 
adotado, no SOS Criança ele foi adotado por uma pessoa, então meu irmão tem mais contato com eles do que eu, entendeu? Eu não tenho muito contato com eles eu vou, vejo, mas sabe? É aquilo... e-mail a cada 3, 6 meses, por aí... e a minha vida tá assim, né? Eu sempre estou... querendo algo a mais pra mim, entendeu? Tive dificuldades na escola, porque.... então, eu estudei, eu estudei até a oitava série, entendeu? E como que, hoje em dia, oitava série praticamente não é nada, eu estou querendo voltar a estudar, mas... porque quando eu trabalhava na $C$., eu trabalhava numa pizzaria também à noite, então eu saía da C. e ia pra pizzaria, por que? Porque eu tinha que me manter, aí não tem nem pai, nem mãe, nem família nem nada, você mesmo tem que se manter, então eu escolheria... ou eu trabalhava pra bancar a casa, entendeu? Ou eu estudava e pensava no futuro, mas isso, o estudar não me dava vantagens naquele momento, entendeu? Porque o que eu ganhava na C. não dava pra mim me manter durante o mês.... e aí tá assim, hoje em dia eu estou procurando meus contatos, acabei de pegar um telefone de lá da Record pra ligar e.... estou com meus amigos, alguns que conseguiram que nem eu ficar numa, passar por uma emissora, tá fazendo algum trabalho... o A., ele está tentando também me encaixar pra mim fazer uns freela pra ... futuramente talvez, se der me chamarem lá e... tô correndo atrás agora, minha vida está sendo assim....

V. Que mudança, né?

L. É... várias mudanças, porque a gente tem uma passagem por... pelo um lugar, tipo pela Febem... a gente já, a gente já tem noção... é só a gente mesmo ter olhar do que que é o mundo, não adianta uma pessoa que nunca passou... ou fez faculdade, fez isso e aquilo, chegar e falar a Febem é isso, é isso, é isso, a televisão, ela mostra a Febem uma coisa, entendeu?

V. O que que é a Febem, você que passou por lá?

L. A Febem é... um lugar, na onde, na onde te leva, te leva ao mundo do crime praticamente, te leva a uma continuação do mundo do crime, não tem... como é que se diz? Não tem uma... a revolução, não tem uma ajuda especial, entendeu? A televisão mostra a Febem tipo Tatuapé, a os menor tem atividade, tem isso, tem aquilo, mas ali Tatuapé, e os outros lugares e as outras Febem... eles esconde, eles esconde Franco da Rocha, eles esconde Parelheiros, entendeu? Hoje em dia eu não sei como que está, que deve ter mudado algumas coisas, mas eu acho que está do mesmo jeito, do jeito que estava... a gente mal chegava, a gente já apanhava, entendeu? A gente já apanhava e como você vai se recuperar num lugar que você já chega apanhando...

V. O que você acha que precisava ter pra recuperar? Como tinha que ser a Febem? Se é que tinha que ter Febem, não sei como você pensa isso?

L. Não.. assim, deveria ter um lugar disciplinar, sem dizer Febem, entendeu? Febem é... Febem é uma palavra muito forte, é a mesma coisa de cadeia, tipo cadeia, Febem, não é lugar pra pessoa se recuperar, entendeu? Apesar que, também... se a gente for só... tipo.... um menor matou tal fulano, ele vai pro lugar pra ele se recuperar... aí de lá ele vai ter tudo? Que que acontece? Ele mesmo, mesmo ele saindo, ele vai querer fazer a mesma coisa, entendeu? Porque na onde que ele está é muito... tipo, muito disciplinar, todo mundo trata bem... apesar que precisa dessas ganâncias também, né? Desses mau trato, porque senão também ninguém aprende, entendeu?

V. Precisa de mau trato?

L. Não, mau trato que eu estou falando é ser duro também, entendeu?

V. Não desrespeitar... 
L. É, não desrespeitar, entendeu? Eu acho isso... eu acho que precisa....precisa assim ter... ter uma reganância forte e ter uma prioridade também, um futuro... que nem... a maioria não consegue emprego, a maioria rouba porque não consegue emprego, daí... precisa alimentar a família, não consegue emprego, não consegue aquilo, que que eles vão fazer? Aí.. todo mundo fala, aqui não tem trabalho pra menor, ou... tipo... não tem trabalho pra quem não estudou... tipo isso, entendeu? As pessoas vão acatando isso, vão acatando isso... e começam a se envolver com as pessoas que... sabe? Trabalha na boca... . começa a vender droga, começa a passar droga, começa a ... fazer uma fitinha aqui, começa a fazer uma fitinha ali, então quando você vai ver você já está totalmente envolvido, entendeu? Então eu acho assim... que nem, agora que o Lula ganhou, ele tipo.... o que ele falou na televisão ele tem que mostrar, entendeu? Tem que mostrar... tem que dar prioridade pros pobres, por que o sentido prioridade? Prioridade nos termos de trabalho, nos termos de alimentação, entendeu? Porque tem mãe aí que tem 3, 4 filhos, não tem condições de sair pra trabalhar... pra trabalhar... vai deixar os filhos com quem? Com vizinho, vizinho não vai querer ficar com os filhos, entendeu? Aí tem esses CÉUS, tipo ... o tempo, o tempo do CÉU é curto pra mãe no horário de trabalho, então eles tem que ver nessa forma, entendeu? Tem que ver nessa forma ... acho que... é... a televisão tinha que decatar o menor, não só o menor, mas o preso mesmo, que quando sai, alguns tenta se recuperar, tenta procurar um trabalho, tenta mudar de vida e não.... as pessoas vira a cara pra eles, entendeu? As pessoas não olha do mesmo jeito que, tipo.... a eu não passei pela Febem, eu não passei pela cadeia, então eu tenho prioridade dentro do trabalho e aquele que passou, mesmo aceitando ele, fica com pé atrás, porque se some alguma coisa, vai culpar quem? Aquele que não teve passagem? Entendeu? Então eu acho assim, as pessoas deveriam olhar isso.... deveria dar prioridade pra.... o governo Lula deveria ver isso daí, deveria dar prioridade pra essas pessoas também que querem se recuperar, porque não é... não é fácil você pegar e ficar 2, 3 anos numa Febem ou ficar 5, 6 anos em uma cadeia e sair e o mundo estar a mesma coisa, você não consegue emprego nem nada, o que que você vai fazer? Vai ficar aqui passando fome, lógico que não! A pessoa vai querer...

V. No seu caso, você correu atrás de outras coisas, né? O que você acha que aconteceu na sua vida que ... você estava contando... quando você voltou pra casa do seu avô, você estava lá, parecia que estava tudo bem, mas na sua cabeça estava que você queria continuar naquela vida, né?

L É, então...daí foi essas oportunidades, entendeu? Foi as oportunidades que foram surgindo, pra mim não ter esses pensamento, entendeu? Quem me ajudou muito foi o Paulo Santiago que... que me deu a maior força mesmo, que estava comigo ali lado a lado, ele conversava comigo, me chamava pra mim não ficar pensando besteira, confiava em mim, deixava os equipamentos, deixava eu levar os equipamentos pra casa, entendeu? Então ele foi a minha.... a minha esperança de vida, entendeu? Ele foi a minha... como é que se diz? A minha confiança, entendeu? A minha confiança porque é muito difícil você... é... ter passado pela Febem é... o povo sabe que você rouba, sabe que você faz aquilo... e dá uma coisa na sua mão de... 4 mil, 5 mil.. deixar com você assim ainda de você levar pra casa, entendeu? Então ali foi na onde que eu vi que estava tendo confiança em mim... a minha vó começou a me ajudar também, meus tios iam lá conversar comigo, aí foi na onde que eu fui... perdendo... perdendo essa trauma de ficar ... ah quero roubar, quero aquilo, quero ter meu dinheiro aí, tipo... começar conseguir minhas coisas, começar consegui... é tirar habilitação, consegui comprar meu carro, consegui comprar minha moto e.... eu fui 
conseguindo várias outras coisas, entendeu? Consegui comprar minha casa agora mesmo passando dificuldades agora mesmo, porque todo mundo precisa de um trabalho... então eu tô feliz entendeu? Eu não me deixo levar... eu não... não me vejo mais nessa forma de precisar roubar pra mim ter as coisas, entendeu?

V. E quando um garoto novo entra nesse mundo, comete uma infração, o que você acha que leva ele?

L. Uma lição de vida.... acho que não adianta a família conversar, não adianta... tipo... você dar conselho, eu dar conselho, a gente tem que passar por isso pra saber qual que é a realidade, entendeu?

V. O que se aprende nessa realidade?

L. Ah... a gente aprende muita coisa...muita coisa.... ah, a gente aprende que.... que nem as pessoas falam, o mundo do crime não é um lugar de diversão, entendeu? Mesmo você... pô, você pode ser considerado o que for... você pode ser o bandido que for, você tá lá dentro.. você deu um pezinho, alguma coisa errada, neguinho vai e te mata, ninguém quer saber se você é..... um bandidão ou se você é um zé ninguém, entendeu? Então isso as pessoas começam a aprender, tem muito adolescente aí que completa... que começa a completar 18,19 anos, vai preso e não agüenta.... não agüenta $0 . .$. aperto lá dentro, porque é.... é.... ali é um lugar que.... meu! Não tem... não tem como você falar, "não, aqui eu vou me recuperar", aqui é....

V. Nem na internação, nem na semi...

L. Não... em nenhum lugar....

V. Nem na LA, como foi sua LA?

L. A LA, eu acho que a LA não existe, entendeu? Porque eu ia lá.... a assistente social conversava comigo, eu voltava pra casa e era a mesma coisa, então não... eu não tive uma ajuda, ela não me ajudou em nada, entendeu? Só conversar e mais nada, que que é isso? Entendeu? Que nem fizeram um projeto ali no Tatuapé agora... que os adolescentes sai da Febem... é, quando os adolescentes vai pra semiliberdade, vai pra lá faz curso e depois vai... e depois volta e vai dormir lá, fica o dia todo fazendo curso, depois volta pra dormir lá.... na semiliberdade que está tendo agora... eu acho que é ali na Bresser ou no Tatuapé, não me lembro.... eles vão dormir na semiliberdade.... eles vão dormir na semiliberdade e vão pra lá fazer o curso.... isso eu acho bom, isso é uma coisa que começou agora em... 2004, alguma coisa assim... 2003, 2005... não me recordo muito bem, eu fui com o Paulo lá, mas... foi coisa rápida... então, isso eu acho bom... isso é um... tipo, isso é uma coisa pro menor, pro adolescente não ficar com os pensamentos de ficar querendo fazer furto ou matar alguém... e isso, e tipo pra ter um futuro pra eles, entendeu? Porque hoje em dia o que manda é a computação, se você não souber ligar um computador, você... praticamente não está sendo ninguém, entendeu? Então... o que eles deveriam fazer mais é dar... é... o mercado de trabalho tinha que abrir pra essas pessoas, entendeu?

V. Você acha que assim ia resolver?

L. É... não ia resolver tudo porque, mesmo tendo... mesmo tendo.... todas essas regalias, tendo essas oportunidades, não ia resolver tudo porque o mundo não dá pra resolver tudo... não dá....não tem como resolver tudo, mas seria uma boa opção de ajuda... Ao masculino e ao feminino também, que... hoje em dia é a mesma coisa, porque... na parte como eu fui ver, quando eu fui gravar lá a Febem das meninas, nossa! Tinha menina ali que você olhava, falava "meu, que você está fazendo aqui?" entendeu? Porque tinha menina que não precisava daquilo, é isso que eu estou falando.... as pessoas precisam, precisam passar por, precisam ver como que é pra 
aprender, porque tem menina aí que tem pai, tem mãe, tem vida boa aí e fíca... vai roubar!

V. Você tem idéia do que leva elas a roubar?

L. Amizade! Amizade... amizade... amizade e liberdade da mãe e do pai, tipo, pode sair, pode fazer o que quiser, tudo começa no baile, né? Vai a primeira vez num baile, aí faz a segunda vez, você vai pegando amizade, amizade, amizade, quando você vai ver... "ah vamos ali fazer não sei que", aí você faz a primeira vez dá certo, faz a segunda vez dá certo, aí você não pára mais, enquanto você não... não vê aquele objetivo: você morre ou você sobrevive e vai preso, você....

V. Chega nesse limite, né?

L. Chega nesse limite... que nem esse meu parceiro que eu estava falando que... ele, a mãe dele e ele deu uma força pra mim, pra mim passar o final de semana lá, ele... tipo... ele não tinha passagem nem nada, ele trabalhava na Vega, tudo... e ele tipo, sabe? Foi um menino sossegado... aí conforme foi passando esses tempos, ele começou a ter uma amizade diferente lá, entendeu? Começou a ter uma amizade diferente, aí mesmo trabalhando ele começava a roubar, com 18 anos! Começava a roubar, começava a fazer isso e aquilo e a mãe dele, tipo doente, entendeu? Doente, conversava com ele, eu conversava com ele, mas... o conversar não adianta, conversar não adianta mesmo, aí ele pegou e foi preso... foi preso... cadeia, tinha 18 , foi preso... e o que que aconteceu? Nessa que ele foi preso, estava ele e outro rapaz que tinha saído da cadeia, o rapaz tinha saído da cadeia, passou dois dias foi roubar, chamou o M. pra roubar. Ainda eu tinha falado pro M.: M. vamos sair à noite, sabe? Pra disfarçar ele entendeu? Vamos sair à noite, ele: "não, vou ali, não sei que" Peguei e falei, Não! Vamos sair à noite e ele "vamos". Aí na hora que eu fui à noite na casa dele, cadê ele? Já tinha ido.... nessa que ele foi, eles foram roubar um carro, aí não sei o que aconteceu lá, os polícia estavam passando, ele foi preso e o maluco morreu, o maluco que estava com ele morreu. Aí eu falei, ele foi preso, tudo, eu mandava carta pra ele... a gente conversava, tudo... aí eu peguei e falei pra ele: meu, sua mãe está doente aqui fora, vê que você não dá trabalho, entendeu? E tipo, ele lá dentro... ficava se envolvendo, usando droga, tipo.. o pai dele pagava advogado aqui à toa pra tirar ele e ele lá gastando dinheiro, entendeu? Pedia dinheiro pro pai dele pra... pagar dívida de droga isso e aquilo... aí ele pegou e ... eu falei: isso daí foi um sinal pra você, entendeu? A sua sorte que você não morreu, você foi preso, entendeu? Isso aí é um sinal pra você, então quando você sair você já... põe a cabeça no lugar, se liga, né? E nisso que ele está lá preso, a mãe dele chegou a falecer... e aí foi naonde que não deixaram ele ir no enterro da mãe dele, o juiz não autorizou, entendeu? Aí ele pegou e saiu e, sabe? Não queria saber de nada mesmo, aí eu conversava com ele, falei: meu tua mãe já foi, mas você tem seu pai aí, não sei que, põe a cabeça no lugar, né? Aí sabe, a gente conversava, conversava, aí ele foi roubar com o vizinho de novo, foi roubar com o vizinho.. de uns pessoal dos crente, não sei da onde, aí pegou e... ele foi preso de novo e o cara saiu fora.. tipo... ele foi, ele estava indo com o carro roubado, a polícia parou o carro roubado, o outro pegou e foi embora, tipo, deixou ele na mão... aí ele foi preso de novo, aí eu peguei e falei: isso daí é pra você aprender, entendeu? Quando eu falei pra você.... não acreditou.... e tipo a sorte dele é que os crentes não deram... não deram queixa nem nada.... nem foram na audiência nem nada, então que que aconteceu? Ele pegou e jogou uma mentira lá... falou que... falou que o carro.... tipo o carro era de um amigo dele e o amigo dele pediu pra ele levar o carro, ele pensou que era do amigo dele e estava levando... então os crentes nem foram recorrer pra ver quem era, nem nada e tipo 
ele ficou acho que 6 meses e saiu, ainda falei pra ele, isso daí é sorte, entendeu? Porque você ia ter a segunda passagem, só ia sair daqui 7 anos, aí tipo foi naonde que ele se envolvia, entendeu? Ele se envolvia, se envolvia, se envolvia... aí eu peguei e dei uma dura nele, entendeu? Dei umas porradas nele... aí ele pegou e tipo.... ficou lá na dele, né? Aí começou a trabalhar na boca lá... aí eu peguei e falei: ó, cheguei nos caras lá e falei: ó meu ele é tipo um irmão pra mim, entendeu? A mesma consideração que vocês têm por mim aqui vocês têm por ele, então meu, não quero ver ele se afundar aí entendeu? Foi preso 2 vezes e tem o pai dele aí que está lutando, tem a irmã dele que ganhou nenê aí, mas tá morando com um maluco aí, tudo.... e o pai dele está sofrendo meu, aí os maluco pegou.... e eu tive que ameaçar ele, entendeu? Eu tive que pegar a arma e falar pra ele: ó mano, se você voltar aqui de novo eu vou te matar, isso e aquilo, aí tipo, ele ficou com aquele receio, né? ele falou ... "puta, perdi meu amigo, isso e aquilo, perdi meu irmão" que a gente se chamava de irmão, "perdi meu irmão" eu falei: não, você não perdeu, você não me perdeu, você está se perdendo, entendeu? Aí os caras lá concordou, tudo, aí não deixou ele ir trabalhar mais lá. Aí beleza, aí ele se ajuntou com uma menina e nisso ele engravidou a menina, aí tipo, começou a morar com, aí ele tava morando com o pai dele, tudo, aí o pai dele viu que ele tava mudando, estava diferente, o pai dele foi e falou "ó, você quer morar com a menina, é... mora aqui.... acho que passou uns 3,4 anos ... o pai dele pegou.., não... é, ele tem 22 agora, passou uns 4 anos, o pai dele arranjou uma outra mulher, né? Pra continuar a vida, acho que isso é natural...., arrumou uma outra mulher e ele está pra se casar agora e ele pegou e falou "ó, você fica com a casa aqui debaixo..." e a irmã dele, largou lá do marido dela com filho e tudo.... e voltou pra casa também, ele pegou e falou "ó, vou fazer assim, vou construir em cima pra um e embaixo pra outro" aí ele foi construiu em cima pro M., tudo e a irmã dele está morando embaixo, o pai dele está lá ainda, mas ele vai se casar agora e vai sair, né? Aí o M. agora está trabalhando, tudo, está trabalhando nesses.... sabe que teve... esses negócios de queimar ônibus, tudo? Então, o rapaz lá em Santo André, conhecido do pai dele, chamou ele pra trabalhar lá pra arrumar os ônibus, tudo... e ele está aí, está bem diferente agora, vai ter um filho dele agora com a menina, então ele comprou os móveis pra casa dele, está... sossegado....

V. O que você acha que fez ele sair dessa onda, L.? Você contribuiu?

L. Ah... eu acho que... eu contribuí numa parte, mas quem contribuiu mesmo foi ele, foi ele mesmo, como foi eu mesmo que me contribuí, senão não tinha jeito mesmo... então o que que aconteceu? Ele teve que passar, ele teve que passar duas vezes pela cadeia pra ele vê? Entendeu? Acho que a primeira não foi suficiente, teve que passar a segunda.... e.... acho que a perda da mãe dele foi fatal pra ele, mexeu.... e agora ele está aí....

V. Você falou uma coisa parecida também, quando era jovem, não tinha pai, não tinha mãe, estava numa situação complicada, era meio que dane-se todo mundo... é assim?

L. Era... porque tipo, eu não tive aquela criação de pai e mãe, entendeu? Pai e mãe desde pequeno, eu tive até os 3 pra 4 anos, entendeu? O que eu fui criado mesmo foi em orfanato, entendeu? Fui criado em orfanato e aí conforme eu fui tendo idade fui passando pela minha família...

V. Eles visitavam você?

L. Não... aí... sabe, hoje em dia eu e meu irmão damos graças a deus da gente está.... a gente está.... é outra cabeça, entendeu? A gente largou de ser é.... como que se diz... adolescente... tipo a gente está naquela faixa de adolescente maduro como se diz, né? 
Mas a gente não vê desse jeito, a gente vê mais adiante, entendeu? A gente já vê mais responsabilidade, a gente não tem uma pessoa que chega na gente e fala é isso, é isso e aquilo, a gente mesmo tem que falar pra gente é isso, é isso e aquilo, entendeu?

V. Quando você está no mundo do crime você vê futuro? Você olha lá pra frente?

L. Você não, vê ganância, você quer ter moto, você quer ter carro, você quer ter vida boa, entendeu? Tipo filme, filme.... você assiste filme aí que neguinho está no fundo do poço, faz isso, faz isso, neguinho já tem de tudo, então é uma influência hoje em dia, hoje em dia é uma influência, uma influência pro... pras crianças, pros adolescentes, é uma influência porque eles se imaginam nisso, né? Ah eu vou ser dono de boca, eu vou ter vários carros, vou ter várias mulheres, isso e aquilo... então não adianta a gente chegar e falar, a gente tem que deixar viver a vida.... a vida, a vida a gente mesmo que aprende, não tem uma pessoa que vai chegar na gente e falar "ó sua vida vai ser isso, isso e isso, segue por esse caminho que vai dar certo" a gente mesmo que tem que seguir um caminho....aí que que acontece? Nesses fato de mudança... a gente tem que procurar aquelas pessoas que, sabe? Acreditam em você, acreditam que você pode conseguir trabalho, acreditam que você pode.... te ajudar num trabalho, pode te ajudar na sua vida, então é.... a gente tem que correr atrás dessas pessoas, porque, na porta de casa todo dia bate lá... "ô vamos fazer uma fita, trabalha aqui numa boca, ou faz isso e aquilo..." entendeu?

V. Esse caminho está disponível o tempo todo?

L. É... esse caminho bate na porta da sua casa, esse caminho bate, todo dia, todo dia bate, então.... pra você ser forte é difícil, é difícil... que nem numa rebelião, uma rebelião você... não é, o pessoal fala, uma rebelião é dentro de cadeia, não... rebelião é o dia-a-dia, entendeu? Rebelião é o dia-a-dia.... cada dia você tem que vencer uma rebelião, senão você..... perde ela completamente....

V. Como que é essa rebelião do dia-a-dia?

L. Rebelião no dia-a-dia é você.... é você acordar... saber que você.... saber que você pode conseguir um trabalho, ou se você tem um trabalho, você vai pro trabalho, faz seu trabalho, volta pra casa, se tá.... ao deitar da noite se está tudo bem, entendeu? Não aconteceu nada com a sua família, não levou uma bala perdida, não levou isso e aquilo, não foi roubar, não foi fazer nada... isso é uma rebelião, entendeu? É você vencer o dia, entendeu? Você não deixar o ... tipo.... o capeta te dominar, porque .... assim, mesmo... mesmo, tipo.... você tendo.... você tendo as coisas, você quer ter mais, você quer ter mais, então... toda hora vem aquela maldade no seu pensamento, então você tem que matar aquilo, entendeu? Você tem que matar... então eu acho que isso é uma rebelião.... uma rebelião da sobrevivência do dia-a-dia, tipo que nem... até seu próprio vizinho, até no seu bairro mesmo, que... como que a gente diz, na cadeia, acontece alguma coisa você debate, você debate... entendeu? Se o maluco está errado, se você está errado, você passa pelo errado e.... tá tudo bem, entendeu? Tipo, tudo bem naquele termo, né? Não está nada bem, mas também não está tão difícil ... e aqui fora é tipo, aconteceu alguma coisa, você vai debater, não tem debate, não tem debate, é bala que rola, entendeu? Ou você morre ou você sobrevive, entendeu? Aqui fora é assim. É isso que é uma rebelião, entendeu? Lá dentro você tem que ser humilde, aqui mais humilde ainda, você tem que saber levar as pessoas, tem que saber conversar com as pessoas, mesmo... mesmo você não querendo, tem sempre aquele que quer desarrumar com você. Hoje mesmo eu vindo no ônibus, eu estou de pé lá no ônibus passa um maluco, tipo que é todo fortão... alto, tá ligado? Faz academia isso e aquilo, tipo eu estou assim de pé, tipo ele passa assim e ... esbarra, mas esbarra com a maldade, sabe? Esbarra com a maldade, eu olhei pra ele assim, 
meu o cara pensa que é forte, mas, pensa que tem o corpo de aço, vai tomar um tiro na cabeça que sossega rapidão, entendeu? Então isso é, isso é a coisa do dia-a-dia, então tipo você olha e fala assim, não, deixa pra lá, nem vou olhar pra não.... entendeu? Estava querendo arrumar, entendeu? Então você tem que fugir dessas.... ocorrências pra não dá fruto, entendeu? Pra não dá fruto porque você acaba se prejudicando, entendeu? Mesmo.... ou você acaba apanhando ou você acaba matando a pessoa e quem se prejudica mais é você, você pode se prejudicar você indo preso, entendeu? Ou senão você consegue fugir pra você.... é só mais um, entendeu? Isso que eu acho que é a rebelião do dia-a-dia, entendeu? A gente tem que ocorrer com tudo isso, e isso daí acontece com todo mundo, tipo você tem um carro, você sai daqui, ali em um farol, neguinho vai e te assalta, entendeu? Isso é... é uma rebelião perdida... você perdeu o que você lutou pra pagar pra .... porque ali você não vai ter de volta, se a polícia não consegue pegar, você nunca mais vai ver seu carro, entendeu? Eu acho assim....

V. Legal.... você falou que parou de estudar na oitava, né? O que aconteceu aí? Quando você era novinho que você começou... que você falou que entrou no mercadinho do bairro... você estava estudando?

L. Então, eu tava e não tava entendeu? Escola.... tipo que nem eu falei, eu não tive aquela pessoa pra falar "pô, escola é fundamental pra sua vida, pro seu futuro..." entendeu? "Você vai ter prioridade numa escola...." então não, ninguém me falava, então não me via....

V. Como você pensa uma relação com um filho seu? Como seria o L. pai?

L. Ah.... seria totalmente mais rígido, né? Mais... seria... porque eu não ia querer deixar ele passar pelo que eu passei, eu queria dar mais.... porque eu gosto de criança, entendeu? Eu tenho uma sobrinha lá que ele é apaixonada por mim, todo dia ela quer ir pra casa... aí... tipo... eu não deixaria ele ver o mundo do jeito que é.... sei lá, botaria ele na escola... mostraria pra ele o que é bom, o que não é bom... porque... se você tem uma pessoa que te mostre ali... o.... o dia-a-dia mesmo, o que é a periferia, a periferia é assim, né? A periferia você aprende dentro, entendeu? Dentro da periferia mesmo, você aprende lá dentro, porque fora você não aprende nada, sua mãe chega e fala "ah.... o mundo é perigoso, neguinho mata...." mas você nunca viu, sabe? Aquilo ali é só uma fala pra você, você nunca viu acontecer, você vê pela televisão, mas você nunca viu na sua frente, você não... nunca teve uma reação diferente, então ali você... você vê ali, você pô.... você está ali conversando de repente chega um e pá, matou o maluco aqui na sua frente, entendeu? Isso acontece diariamente.... entendeu? Então eu mostraria pra ele qual que é o mundo, dentro da própria comunidade, dentro da periferia, como a gente fala, e mostraria pra ele o mundo fora disso, como se diz? Oportunidades, entendeu? Tipo ah, você quer ser jogador, ah você quer ser radialista, você quer ser isso e aquilo, você tem que estudar, tem que aprender, pra conseguir seu futuro mais pra frente, entendeu?

V. Não tem saída na comunidade?

L. Você tem que sair dali, é... ali a gente... pô, tem que mostrar pra ele como que faz pra ele sair dali, senão... se ele ficar nesses pensamentos ele nunca vai sair dali, entendeu? Nunca vai ter um... uma vida fora, nunca vai ter um conhecimento fora, nunca vai poder, tipo, andar de avião, que nem as pessoas lá mesmo onde eu moro, as pessoas falam "ah, pô, queria andar de avião, isso e aquilo". Peguei e falei, meu, você quer andar de avião... é só você correr atrás... é só você correr atrás, que eu já ... eu consegui andar de avião... foi eu e o A., a gente foi lá pro Rio... a gente estava fazendo um trabalho pra Petrobrás, lá em Votarantin, a G. tava fazendo um trabalho 
lá, a gente foi pra lá... a gente estava fazendo um freela pro... pro Museu da Pessoa, aí ela pegou a gente e levou pra lá, e o A. é outro guerreiro também, que ele conseguiu também a vida dele, conseguiu... a não deixar se levar... ele conseguiu viajar pra vários lugares, Bahia, Amazonas... ele é... assim... um amigo que você se inspira, entendeu? Ele, tipo se inspira em mim e eu me inspiro nele... uma coisa que....

V. E vocês têm contato até hoje?

L. Até hoje a gente sempre está conversando, está tentando ajudar um ao outro, então é assim... da parte do meu filho eu acho que, mesmo sendo menina ou menino, tinha que ter um... uma pessoa pra dar um exemplo, um exemplo de... está ali todo dia, não só o falar... um amigo chegar e é isso e aquilo, o tempo todo lá fora... você nunca vai ver se não tiver uma pessoa do seu lado te mostrando como que é o mundo... É assim, você aprende o dia-a-dia, você aprende o dia-a-dia, cada dia é um aprendizado, cada dia é uma escola pra você, um aprendizado diferente....

V. Legal.... quer contar mais alguma coisa?

L. Não.... é..... eu acho que as pessoas.... as pessoas deveriam, tipo a Febem, a Febem tinha que dar oportunidades pra ... pras pessoas de fora ver como que é lá dentro, mostrar o mundo real, não um mundo falso, entendeu? Mesma coisa na cadeia, na cadeia eles falam... é, presídio bonito aqui... fiz outro ali, fiz outro ali, mas e o dia-adia daquelas pessoas, entendeu? Que nem tem... na onde que o Fernandinho Beiramar está lá, você fica na cela o dia todo sem poder fazer nada, é mais fácil a pessoa se matar, entendeu? Ficar trancado ali no local o dia todo, você não vê ninguém, não vê sol, não vê nada e aí isso é vida pra o ser humano? Como é que a pessoa vai se recuperar daquele jeito? O que que ele vai fazer? Vai fugir e continuar aprontando... porque não tem, não tem um... uma ajuda pra eles, não só pra eles como pras outras pessoas....

V. Você acha que as pessoas sabem o que é andar pelo caminho certo e o que não é?

L. Ah sabe! Sabe!

V. Desde cedo?

L. Desde cedo sabe, é a mesma coisa que você ter um filho, você sabe que tem um filho agora... é você ter responsabilidade para o resto da vida, entendeu? Ainda mais mãe, né? Porque pai... tem pai que faz o filho e solta... ainda mais mãe, tipo faz o filho adolescente, já era sua vida, já era sua infância... vai viver agora a partir de mulher mais velha, de mãe, entendeu? Acho assim.. que nem você falou, as pessoas sabem... supõe o filho do Pelé, o filho do Pelé era jogador, era goleiro, tinha tudo... pra que se envolver em droga?

V. O que você imagina? O que será que fez ele se envolver?

L. É... amizade, amizade, amizade que ele se deixou levar... ele se deixou levar... não só ele como várias pessoas, esse negócio do governo aí que tem... de compra não sei do que lá.... corrupção envolvendo dinheiro... entendeu? É um querendo pegar do outro entendeu? Querendo derrubar o outro... então as pessoas sabem o que estão fazendo, mas....

V. Dá pra segurar a onda pra não fazer?

L. É.... é se você tiver uma inspiração, se você falar, não eu quero isso! Se você não tiver objetivo nenhum você vai fácil, entendeu? Você vai fácil! Fala, ah isso daqui não vai me dar futuro, eu não vou conseguir mais nada então demorou, entendeu?

V. E pra ter esse objetivo, como que é? 
L. Ah pra ter objetivo é de cada pessoa! É de cada um... e é difícil hein? É muito difícil ... é... umas coisas que só você mesmo sabe explicar, só você mesmo tem, só você mesmo sabe o que precisa, só você mesmo sabe o que você quer, senão....

V. Da onde vem a nossa vontade, da onde vem o nosso objetivo na vida? Alguém que ensinou, a gente viu em algum lugar? O que será que é?

L. Não, é o ver... é o ver... tipo objetivo, vai você vê o carro, você vê um carro na rua, vê um carro na televisão... você vê tipo a pessoa dirigindo, você não tem um carro, o que você quer fazer? Puta! Quero ter um carro! Entendeu? Quero ter um carro, quero andar de carro, qual que é o seu objetivo? Trabalhar pra comprar aquele carro, é a mesma coisa entendeu? Ou senão a pessoa, vou roubar pra comprar aquele carro, entendeu? Cada um vê com uma visão diferente, entendeu? É isso que é o ver...

V. Gostei quando você falou a vida é uma rebelião a cada dia... é isso mesmo.

L. É...

V. Pra cada um, né? E a rebelião é diferente pra cada um...

L. É diferente, não só pra... não só o modo de ... assim, de materiais ou do ser humano, é a sobrevivência também, porque a rebelião, tipo, a mãe vai ter um neném no hospital e mãe não consegue sobreviver, nem o filho sobrevive, entendeu? Ali perdeu a rebelião, ali perdeu a rebelião da vida, perdeu a rebelião da vida... então é... bem assim....

V. Legal, então... acho que é isso...

L. Se precisar de novo.... vê se gravou.... 
REFERÊNCIAS BIBLIOGRÁFICAS 


\section{REFERÊNCIAS BIBLIOGRÁFICAS}

ABRAMO, H. W. ; FREITAS, M.V.; SPOSITO, M. P. Juventude em debate. São Paulo: Cortez. 2000.

ADORNO, S. A experiência precoce da punição in MARTINS, J.S. (coord) $O$ Massacre dos Inocentes: a criança sem infância no Brasil. 2 Ed. São Paulo: Hucitec. 1993. p181 a 208.

ADORNO, S.; BORDINI, E. B. T.; LIMA, R. S. O adolescente e as mudanças na criminalidade urbana. São Paulo em Perspectiva. São Paulo, v. 13, n. 4, 1999. Disponível em: <http://www.scielo.br>. Acesso em: 21 nov 2006.

ADORNO, S. Ética e Violência: adolescentes, crime e violência in ABRAMO, H. W.; FREITAS, M. V. ; SPOSITO, M. P. Juventude em Debate. São Paulo: Cortez. 2000 .

ADORNO, S. Criança e Adolescentes e a Violência Urbana. 2002. Disponível em <http://www.nevusp.org.br/downloads/down76.zip>. Acesso em: 21 nov 2006.

ADORNO, S. Exclusão Sócio-Econômica e Violência Urbana - NEV- USP; Preparado para o ciclo de Conferências "Sociedad sin Violência", promovido pelo PNUD - $\quad$ El Salvador. Disponível em: <http:// www.nevusp.org.br/downloads/down77.zip>. Acesso em: 21 nov 2006.

ADORNO, T. W. Teoria da Semicultura in Educação e Sociedade. São Paulo: Cedes/Papirus. Ano XVII, no 56. Dezembro. 1996.

ALMEIDA, E.M.; HOJDA, A.; KAHN, T. ; SPOSATO, K. B. Defesa Técnica de Adolescentes Acusados da Autoria de Atos Infracionais em São Paulo. Revista do Ilanud n. 22. São Paulo. 2002.

ANDI. Balas Perdidas: um olhar sobre o comportamento da imprensa brasileira quando a criança e o adolescente estão na pauta da violência. ANDI/DCAMJ/AMENCAR. Novembro 2001. Disponível em: <http://www.andi.org.br>. Acesso em: 23 maio 2007.

ANDI. Relatório Infância na Mídia: a criança e o adolescente no olhar da imprensa brasileira. Apoio UNICEF/ Inst, Telemig Celular/ Inst. Ayrton Senna. ANDI. Ano 10. Número 14. Julho 2005. Disponível em: <http://www.andi.org.br>. Acesso em: 23 maio 2007.

ANDI. Direitos, Infância e Agenda Pública: uma análise comparativa da cobertura jornalística latino-americana. ANDI/ Rede ANDI América Latina. Brasília: ANDI 2007. 74p. il. color. Disponível em: <http://www.andi.org.br>. Acesso em: 15 set 2007. 
ARDANS, O. e TASSARA, E. Participação emancipatória: reflexões sobre a mudança na complexidade contemporânea. Imaginário - LABI. Instituto de Psicologia. Universidade de São Paulo. Nº9. p.15-31. 2003.

ARENDT, H. Entre o Passado e o Futuro. Tradução Mauro W. Barbosa de Almeida. Coleção Debates (Política). 2 ed. São Paulo: Editora Perspectiva. 1988.

ARENDT, H. A Condição Humana. Tradução Roberto Raposo. (Posfácio) Celso Lafer. 8 ed (Revista). Rio de Janeiro: Forense Universitária. 1997.

ARENDT, H. Origens do Totalitarismo Tradução Roberto Raposo. São Paulo. Companhia das Letras. 1989. $5^{\text {a }}$ reimpressão 2004.

ASSIS, S. G. Traçando caminhos numa sociedade violenta: a vida de jovens infratores e seus irmãos não infratores. Sumário Executivo. Brasília: FIOCRUZ CLAVES/UNESCO/Departamento da Criança e do Adolescente - Secretaria de Estado dos Direitos Humanos - Ministério da Justiça. 65p. il. (Série Superando a Violência. V. 3) Coleção Garantia de Direitos. Série Subsídios. Tomo 4. 1999.

BENJAMIN, W. Sobre Alguns Temas em Baudelaire. In. Benjamin, W. Charles Baudelaire, um lírico no auge do capitalismo. São Paulo. Brasiliense. 1989.

BOURDIEU, P. (org) A Miséria do Mundo. 3. Ed. Petrópolis: Vozes. 1999.

BRASIL. Estatuto da Criança e do Adolescente. Lei N 8069. 13 de julho de 1990. Disponível em: <http://www.planalto.gov.br/civil_03/Leis/L8069.htm>. Acesso em: 21 nov 2006.

CALIL, M. I. Do menino de rua a adolescente: análise sócio-histórica de um processo de ressignificação do sujeito. In: OZELLA, S. (Org) Adolescências Construídas: a visão da psicologia sócio-histórica. São Paulo: Cortez. 2003. p. 137166.

COUTO, I. A. P. \& MELO. V. G. Reconstruindo a história do atendimento à infância no Brasil In: BAZILIO, L. C.; EARP, M.L.S.; NORONHA, P.A. Infância tutelada e educação: história, política e legislação. São Paulo: Ravil. 1998.

CURY,M.; GARRIDO, P.A.\& MARÇURA, J. N. Estatuto da Criança e do Adolescente Anotado- Apêndice - Legislação 3 ed. revista e atual. São Paulo: Editora Revista dos Tribunais, 2002. p. 288-297.

DAMERGIAN, S. e TASSARA, E. T. O. Para um novo humanismo: contribuições da psicologia social in Revista de Estudos Avançados. Universidade de São Paulo. Instituto de Psicologia. São Paulo: IEA. 10 (28). 1996.

FEFFERMANN, M. Vidas Arriscadas: o cotidiano dos jovens trabalhadores do tráfico. Petrópolis. RJ: Vozes. 2006. 
FREITAS, S. M. História Oral: Possibilidades e Procedimentos. São Paulo: Humanitas, 2002.

GONÇALVES FILHO, J. M. Passagem para a Vila Joanisa. 1995. 171f. Dissertação (Mestrado em Psicologia). Instituto de Psicologia. Universidade de São Paulo. São Paulo. 1995.

GUBA, E. G. The Paradigm Dialog. Califórnia: Sage Publications. 1990.

HORKHEIMER, M. e ADORNO, T. W. A Indústria Cultural: o esclarecimento como mistificação das massas. In Dialética do Esclarecimento. RJ: Jorge Zahar, 1985.

MARIN, I. S. K. Violências. São Paulo: Escuta/FAPESP. 2002.

MARTINS, J. S. Sobre o modo capitalista de pensar. São Paulo: Hucitec. 1980.

MARTINS, J. S. Exclusão Social e a Nova Desigualdade. 2ed. São Paulo: Paulus. 2003a. (Coleção Temas da Atualidade).

MARTINS, J. S. A Sociedade Vista do Abismo: novos estudos sobre exclusão, pobreza e classes sociais. 2ed. Petrópolis - RJ: Vozes. 2003b.

MELLO, S. L. Estatuto da Criança e do Adolescente: é possível torná-lo uma realidade psicológoca? In Revista Psicologia USP. São Paulo. IPUSP. V.10, n2, 1999. Disponível em: <http://www.scielo.br> Acesso em: 10 out 2004.

MELLO, S. L. Das Bruxas, dos Índios, dos Negros e dos Jovens da Febem in Paidéia: Cadernos de Psicologia e Educação. Ribeirão Preto. v11. n.20. p. 79-84. 2001.

MORAES, E. Criminalidade da Infância e da Adolescência. 2ed. Rio de Janeiro: Livraria Francisco Alves. 1927

NJAINE, K. \& MINAYO, M. C. S. Análise do discurso da imprensa sobre rebeliões de jovens infratores em regime de privação de liberdade. Ciência e Saúde Coletiva. Rio de Janeiro. V. 7, n. 2, 2002. Disponível em: <www.scielo.br>. Acesso em: 15 março 2007.

OZELLA, S. Adolescência: uma perspectiva crítica. In: CONTINI, M.L. J. (Coord.). e KOLLER, S. H. (Org.). Adolescência e Psicologia: concepções, práticas e reflexões críticas. Rio de Janeiro: Conselho Federal de Psicologia, 2002. p. 16-24.

OZELLA, S. A adolescência e os psicólogos: a concepção e a prática dos profissionais. In: OZELLA, S. (Org) Adolescências Construídas: a visão da psicologia sócio-histórica. São Paulo: Cortez. 2003. p.17-40. 
PEREIRA. R.F.S. Movimento de Defesa dos direitos da criança e do adolescente: do alternativo ao alternativo. 154f. Dissertação de Mestrado (Mestrado em Serviço Social. Pontifícia Universidade Católica. São Paulo. 1998.

PERES, M. F. T.; CARDIA, N.; SANTOS, P.C. Homicídios de crianças e jovens no Brasil: 1980-2002. São Paulo: Núcleo de Estudos da Violência. Universidade de São Paulo. NEV/USP. 311p. 2006. Disponível em:<www.nevusp.org.br>. Acesso em: 17 março 2007.

QUEIROZ, M. I. P. Relatos Orais: do "indizível” ao "dizível”. In: VON SIMSON, O. M. (Org) Experimentos com Histórias de Vida. São Paulo: Vértice. 1988.

ROMAN, M D. Psicologia e adolescência encarcerada: a dimensão educativa de uma atuação em meio à barbárie. 2007. 285f. Tese (Doutorado em Psicologia). Instituto de Psicologia. Universidade de São Paulo. São Paulo. 2007.

SALES, M. A. (In)Visibilidade Perversa: adolescentes infratores como metáfora da violência. 2004. 280f. Tese. (Doutorado em Sociologia). Faculdade de Filosofia, Letras e Ciências Humanas. Universidade de São Paulo. São Paulo. 2004.

SAYÃO, Y. Políticas Públicas de Atendimento para a Infância e Adolescência Breve Histórico do Estatuto da Criança e do Adolescente. 13 março de 2002. (mimeo).

TRASSI, M.L. Adolescência-Violência: desperdício de vidas São Paulo: Cortez Editora. 2006.

VICENTIN, M. C. G. A Vida em Rebelião: jovens em conflito com a lei. São Paulo: Hucitec-Fapesp. 2005.

VIEIRA, R.A.F. $O$ Ato infracional na perspectiva do adolescente em conflito com a lei: um estudo sócio-histórico. 2003. 204f. Dissertação (Mestrado em Psicologia). Pontifícia Universidade Católica, São Paulo, 2003.

WAISELFISZ, J. J. Mapa da Violência 2006 - Os jovens do Brasil. Brasília: OEI Organização dos Estados Ibero - Americanos para a Educação, a Ciência e a Cultura. 2006. Disponível em:<http://www.oei.org.br>. Acesso em: 03 dez 2007.

WINNICOTT, D. W. Privação e Delinqüência. Tradução Álvaro Cabral. Verificação de Tradução Mônica Stahel. São Paulo: Martins Fontes. 4 ed. 2005.

YIN, R. K. Estudo de Caso: planejamento e métodos. 2 ed. Tradução. Daniel Grassi. Porto Alegre: Bookman. 2001. 